MARCUS COIMBRA ISRAEL

Ensaios não destrutivos aplicados à avaliação de revestimentos de argamassa 
MARCUS COIMBRA ISRAEL

\section{Ensaios não destrutivos aplicados à avaliação de revestimentos de argamassa}

Dissertação apresentada à Escola Politécnica da Universidade de São Paulo para obtenção do título de Mestre em Engenharia.

Orientador: Prof. Dr. Rafael Giuliano Pileggi

São Paulo

2016 
MARCUS COIMBRA ISRAEL

\section{Ensaios não destrutivos aplicados à avaliação de revestimentos de argamassa}

Dissertação apresentada à Escola Politécnica da Universidade de São Paulo para obtenção do título de Mestre em Engenharia.

Área de Concentração: Engenharia de Construção Civil e Urbana

Orientador: Prof. Dr. Rafael Giuliano Pileggi

São Paulo

2016 
Este exemplar foi revisado e alterado em relação à versão original, sob responsabilidade única do autor e com anuência de seu orientador.

São Paulo, 13 de janeiro de 2016.

Autor: Marcus Coimbra Israel

Orientador: Rafael Giuliano Pileggi

FICHA CATALOGRÁFICA

Israel, Marcus

Ensaios não destrutivos aplicados à avaliação e controle de revestimentos de argamassa / M. Israel, R. Pileggi -- São Paulo, 2016.

$167 \mathrm{p}$.

Dissertação (Mestrado) - Escola Politécnica da Universidade de São Paulo. Departamento de Engenharia de Construção Civil.

1. Ensaios não destrutivos 2. Escaneamento 3D laser 3.Termografia infravermelha 4. Revestimentos de fachada I. Universidade de São Paulo. Escola Politécnica. Departamento de Engenharia de Construção Civil II. t. III. Pileggi, Rafael 
Nome: ISRAEL, Marcus Coimbra

Título: Ensaios não destrutivos aplicados à avaliação de revestimentos de argamassa

Tese apresentada ao Departamento de Engenharia de Construção Civil da Escola Politécnica da USP (EPUSP) para obtenção do título de Mestre em Engenharia.

Aprovado em:

Banca Examinadora

Prof. Dr. Instituição:

Julgamento: Assinatura:

Prof. Dr. Instituição:

Julgamento: Assinatura:

Prof. Dr. Instituição:

Julgamento: Assinatura:

Prof. Dr. Instituição: Julgamento: Assinatura:

Prof. Dr. Instituição: Julgamento: Assinatura: 


\section{AGRADECIMENTOS}

Expresso aqui o reconhecimento a todos que contribuíram para o sucesso deste trabalho. Foram muitas barreiras transpostas, mas muitas mãos estendidas.

Ao meu orientador Rafael Giuliano Pileggi de quem levo um aprendizado muito além do acadêmico. Um exemplo de vida profissional e familiar sustentado por uma conduta ética exemplar e muita competência. Obrigado pela oportunidade de desenvolver este trabalho sob sua orientação, pela dedicação, confiança, compreensão, respeito e amizade.

Ao amigo Roberto Cesar Romano pelas tantas revisões, sugestões e conselhos, sempre disponível para contribuir. Aos professores Sérgio Cirelli Angulo e Mércia pelas contribuições na Qualificação desta dissertação.

Ao professor Vanderley M. John, ao professor Antônio Figueiredo e à professora Maria Alba Cincotto presentes no processo de aprendizagem no decorrer das disciplinas e nas conversas informais, participando direta e indiretamente do desenvolvimento desta dissertação.

Aos amigos Danilo dos R. Torres, Franco A. Grandes e Mario S. Takeashi pelo auxílio, disponibilidade e boa vontade que sempre demonstraram no apoio à realização de ensaios. Aos colegas do Laboratório de Microestrutura pela paciência e pelo apoio operacional.

Aos amigos Engracia Bartuciotti, Paulo Hetzmanh (PCC); Reginaldo Mariano da Silva, Adilson Inácio dos Santos e Renata Monte (Hall Tecnológico); Wandréa Dantas e Eliany Funari (PPGEC e SPG) por todo o apoio, pela dedicação e pela disponibilidade para viabilizar o andamento do estudo e ajudar na superação de muitas barreiras.

Aos amigos Pedro Beleza, José Carlos Januário, João Batista Viana e José Airton da Silva por disponibilizarem parte do tempo deles à aplicação da argamassa nos painéis e corpos de prova.

Ao amigo Nielsen Alves pelo apoio técnico na realização das imagens in situ e pela troca de informações e de materiais científicos.

Ao Marcelo Chamma e ao Eduardo Porciuncula pela oportunidade, por acreditarem no projeto e viabilizarem a viagem aos Estados Unidos como parte do processo de levantamento das técnicas de ensaios não destrutivos. 
Ao Maurício Russomanno e ao Ricardo Soares pela confiança e pela compreensão na fase de conclusão deste projeto.

À Votorantim Cimentos pela disponibilização da argamassa de projeção. À ANVI Projetores e Misturadores de Argamassa pelo empréstimo do equipamento de projeção. À Associação Brasileira de Cimento Portland (ABPC) e à Associação Brasileira de Argamassas Industrializadas (ABAI) pela disponibilização dos pórticos utilizados na confecção dos painéis e na disponibilização dos blocos de concreto.

À T1 Engenharia, em especial ao sr. Ricardo pelo apoio no desenvolvimento da etapa experimental de escaneamento 3D e pela disponibilização de dados.

À Flir do Brasil e à Pollus Technik pelo apoio e pelo empréstimo da câmera térmica, em especial aos senhores Fernando Lisboa e Ronaldo por acreditarem no projeto e ao sr. Leonardo por dedicar tempo e especial atenção à troca de conhecimento sobre o uso da câmera térmica.

Aos participantes do Consórcio Setorial para Inovação em Tecnológica de Revestimentos de Argamassa (CONSITRA) pelas sugestões, críticas e oportunidades levantadas ao longo do processo de desenvolvimento do estudo e pelo entusiasmo revelado por esta dissertação.

À minha esposa Cristina e filhos (Rafael e Ana Carolina), companheiros, fonte de inspiração e de certeza de que todo o esforço vale a pena. Sem vocês simplesmente nada teria acontecido.

Aos meus pais, José Israel e Sandra, pelas constantes orações e palavras de apoio. A vocês devo muita gratidão e admiração. $O$ exemplo de correr atrás dos sonhos e lutar por eles até o último minuto tenho como lição em tudo o que faço.

À minha irmã, Ana Paula, fonte inesgotável de admiração e competência. Obrigado por ser minha guia desde os tempos de escola. A todos os familiares e amigos que de alguma forma ajudaram com palavras de apoio e oração.

Talvez, eu não tenha expressado em palavras e não tenha agradecido o suficiente por todo o auxílio recebido ou até mesmo tenha cometido o descuido de não citar alguém; no entanto, posso afirmar que foi imprescindível toda a ajuda recebida. Que Deus abençoe e ilumine a vida de todos.

Finalmente a Deus, por estar sempre ao meu lado fazendo com que eu continuasse sempre firme nesta árdua jornada. 
"Depois de algum tempo você... Aprende a construir todas as suas estradas no hoje, porque o terreno do amanhã é incerto demais para os planos, e o futuro tem o costume de cair em meio ao vão... Começa a aprender que não se deve comparar com os outros, mas com o melhor que pode ser... Descobre que se leva muito tempo para se tornar a pessoa que quer ser, e que o tempo é curto... Aprende que não importa onde já chegou, mas para onde está indo... Aprende que o tempo não é algo que possa voltar... Você aprende que realmente pode suportar... que realmente é forte, e que pode ir muito mais longe depois de pensar que não se pode mais..." 


\section{RESUMO}

Mudanças causadas pela industrialização dos canteiros de obra geram incompatibilidades executivas entre sistemas conflitantes e ininterrupção de controles com significativa variabilidade, tal como o uso do fio de prumo para controle geométrico das estruturas de concreto, responsável por acúmulo de erros com reflexo no consumo de matérias e no aumento de defeitos em revestimentos de fachada. Como alternativa, este trabalho busca colaborar com a ampliação do uso das técnicas não destrutivas no controle preventivo e corretivo das edificações em substituição aos tradicionais ensaios destrutivos, tornando o processo mais simples e confiável, além de proporcionar uma recuperação mais rápida e econômica. Para isso, analisou através de um estudo de caso - a aplicação da tecnologia de escaneamento 3D laser para mapear a planicidade superficial da fachada de um edifício e, de forma inédita, para quantificar o volume de argamassa por intermédio da análise dos modelos 3D gerados por softwares de mercado; e através das etapas experimentais de laboratório, campo e in situ, analisou o potencial da termografia infravermelha na identificação e no mapeamento de fissuras e descolamentos ocultos nos revestimentos de argamassa e cerâmico, aplicando abordagens de aquecimento ativa ou passiva e resfriamento natural ou forçado. Os resultados do escaneamento mostraram a viabilidade da técnica como solução para identificar com precisão as áreas críticas da fachada sobre a estrutura de concreto periférica e alvenaria e, a partir da volumetria, calcular o impacto financeiro associado às sobrespessuras de argamassa nas áreas críticas comparativamente a reduções de espessura após tratamento dessas áreas. Por fim, a termografia identificou quanto à forma, tamanho e posição os defeitos de fissura e descolamento estudados, identificou influências intrínsecas ao processo de uso da tecnologia in situ e uso de recursos do equipamento para melhor visualização dos defeitos.

Palavras-chave: 1. Ensaios não destrutivos. 2. Escaneamento 3D laser. 3. Termografia infravermelha. 4. Revestimentos de fachada. 


\begin{abstract}
Changes caused by industrialization of construction sites generate executive incompatibilities between conflicting systems and uninterrupted controls with significant variability, such as the use of a plumb line for geometric control of concrete structures, responsible for error buildup with reflection in the consumption of materials and the increase of defects on facade coatings. Alternatively, this work seeks to collaborate with the expanded use of non-destructive techniques in preventive and corrective control of buildings to replace the traditional destructive testing, making the most simple and reliable process, in addition to providing a faster and economic recovery. For this analyzed by a case study the application of 3D laser scanning technology to map the surface flatness of the facade of a building, and unprecedentedly to quantify the amount of mortar through the analysis of 3D models generated by software market; and through the experimental stages of laboratory, field and in site, examined the potential of infrared thermography in the identification and mapping of hidden cracks and detachments in mortar coatings and ceramic tile, applying active or passive heating and natural cooling or forced cooling. The results of the scan showed the technical viability as a solution to accurately identify the critical areas of the facade on the peripheral concrete structure and masonry and from the volumes, calculate the financial impact associated with extra thick grout in critical areas compared the thickness reductions after treatment of these areas. Finally, thermography identified as the shape, size and position the cleft defects and detachment studied, identified influences the use of technology in situ and use of equipment resources to better visualization of defects.
\end{abstract}

Keywords: 1. Non-destructive testing. 2. 3D laser scanning. 3. Infrared thermography. 4. Facade coatings. 


\section{SUMÁRIO}

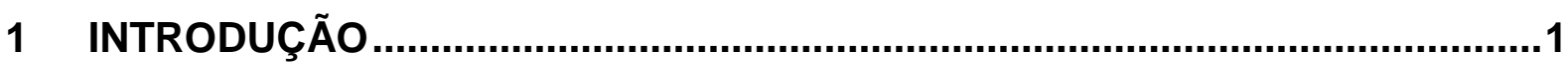

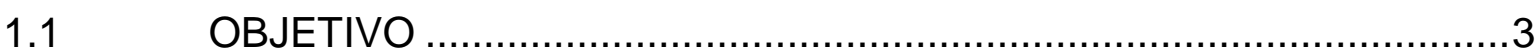

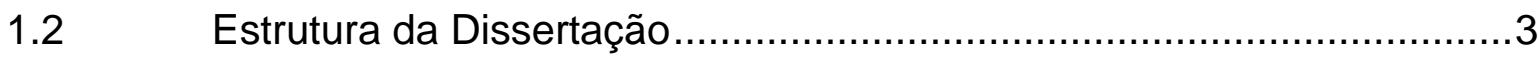

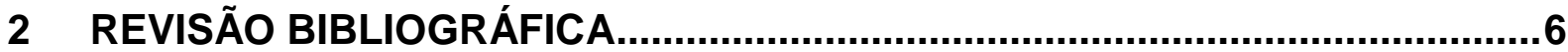

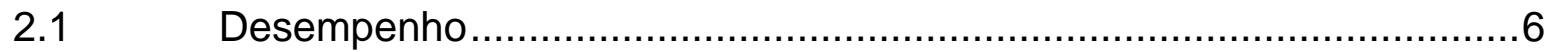

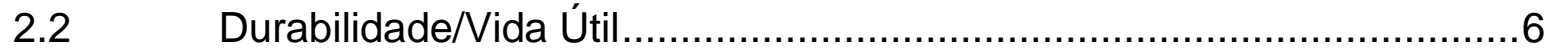

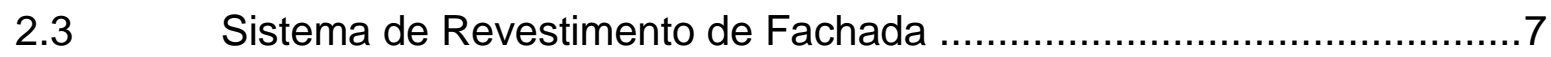

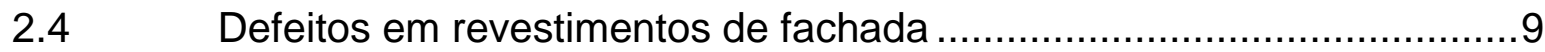

2.4.1 Descolamento/Desplacamento .................................................. 10

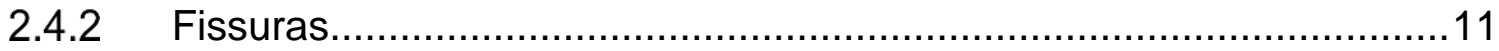

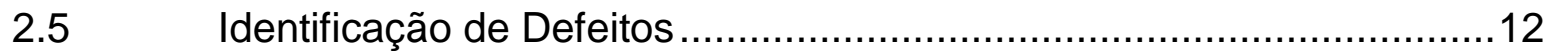

2.5.1 Módulo de deformação (NBR 7190, 1997) .......................................13

2.5.2 Resistência de aderência à tração ............................................... 14

2.6 Controle Preventivo e Corretivo .................................................15

2.7 Impacto do Controle Geométrico da Estrutura de Concreto ................16

2.8 Princípio básico do escaneamento 3D laser ....................................18

2.9 Princípio básico da termografia infravermelha (TIV) ......................23

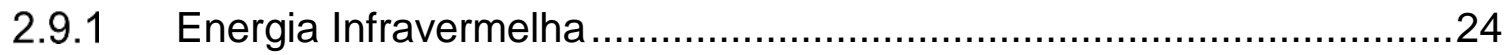

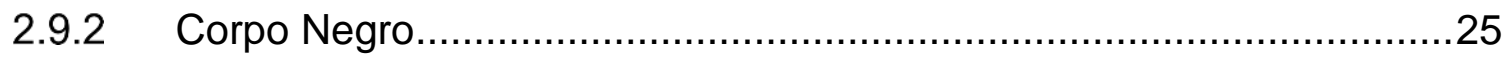

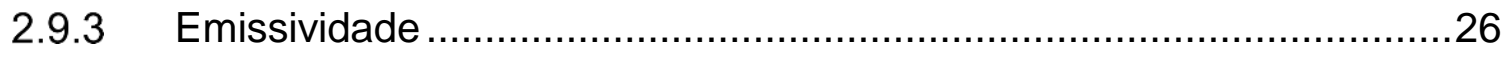


2.9.4 Refletância e Cor

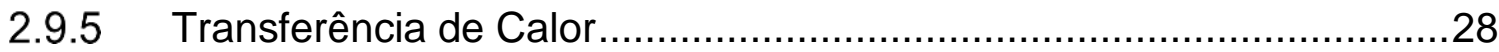

2.9.6 Reflexão, Transmissão e Absorção .................................................30

2.9.7 Câmera Térmica ........................................................................

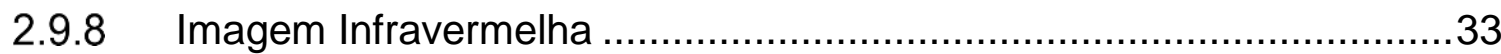

2.9.9 Fatores que influenciam medições termográficas em edificações ........34

2.9.10 Termografia aplicada à identificação de defeitos em edificações .........34

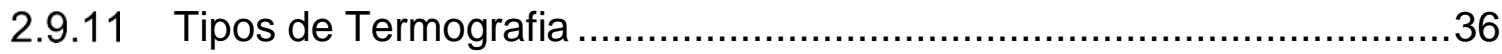

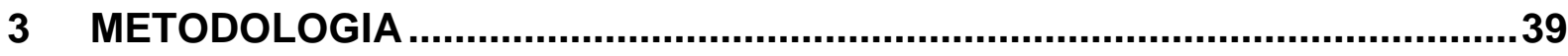

3.1 Escaneamento 3D laser aplicado à planicidade e volumetria de argamassa em fachada ..............................................................................

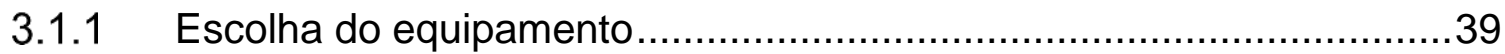

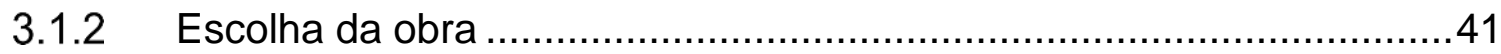

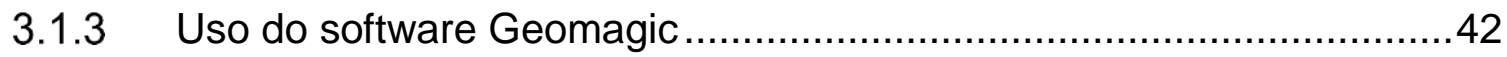

3.1.4 Experimento realizado e definição de planos de referência ..................43

3.2 Aplicação da termografia infravermelha na identificação de defeitos de

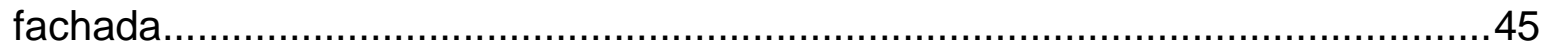

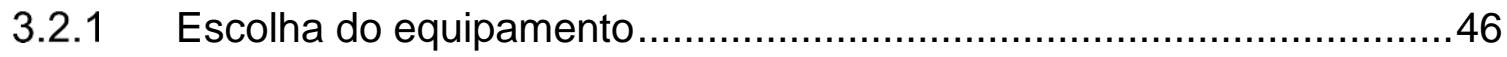

3.2.2 Moldagem dos painéis utilizados nas etapas de laboratório e campo .47

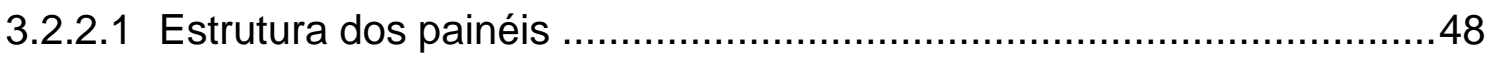

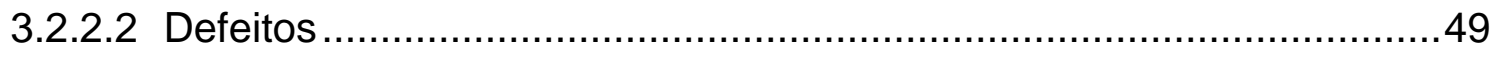

3.2.2.3 Preparo do substrato e inclusão dos defeitos .....................................51 
3.2.2.5 Aplicação da cerâmica 59

3.2.3 Condição de contorno para realização dos termogramas 60

3.2.4 Características preliminares de ensaio .61

3.2.5 Ciclos de aquecimento e resfriamento 62

3.2.6 Experimento realizado .66

3.2.6.1 Planejamento de ensaios: etapas de laboratório e campo 66

3.2.6.2 Planejamento de ensaios: in situ 71

3.2.6.3 Rotina de ensaios 72

4 RESULTADOS 78

4.1 Escaneamento 3D laser aplicado à planicidade e volumetria de argamassa em fachada .78

4.1.1 Limites do uso do escaneamento em obra......................................78

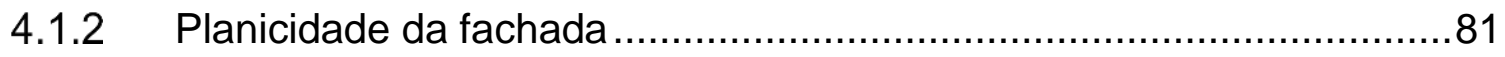

4.1.3 Refinamento em alinhamento e nivelamento da fachada ...................82

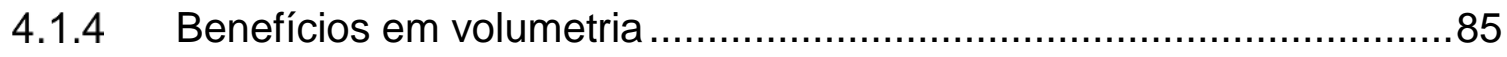

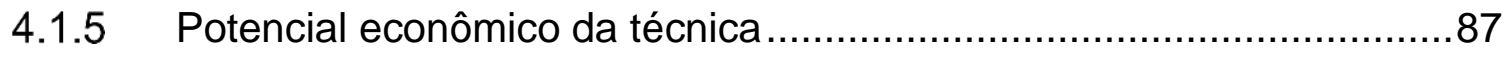

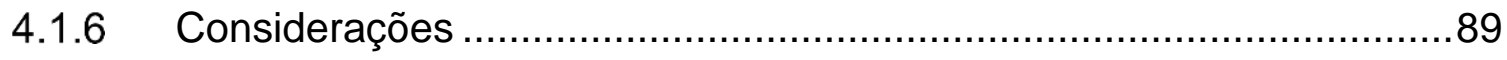

4.2 Aplicação da termografia infravermelha na identificação de defeitos de fachada.

4.2.1 Condição de baixo gradiente térmico ………...................................... 89

4.2.2 Condição de Elevado Gradiente Térmico ………..............................95 
4.2.2.1 Defeitos de descolamento/vazios nos painéis .95

4.2.2.2 Defeitos de descolamento/vazios in situ: Termografia como ferramenta de diagnóstico de descolamento cerâmico em fachada 135

4.2.2.3 Termografia como ferramenta de controle de execução/recuperação de defeitos de desplacamento em revestimento cerâmico de fachada...137

4.2.2.4 Influências do processo de uso da tecnologia de termografia em ambiente aberto

4.2.2.5 Influência dos recursos do equipamento e do software na identificação/visualização dos defeitos em fachada.

4.2.2.6 Defeitos de fissuras nos painéis. 145

4.2.2.7 Defeitos de fissuras in situ 148

4.2.3 Considerações 150

4.2.3.1 Laboratório e Campo 150

4.2.3.2 In situ 152

5 CONCLUSÕES 155

5.1

Sugestões para futuras pesquisas/aplicações 156

6 REFERÊNCIAS BIBLIOGRÁFICAS 


\section{ÍNDICE DE FIGURAS}

Figura 1. Representação esquemática dos agentes atuantes em sistema de revestimento de argamassa (SELMO, 1989). 7

Figura 2. Camadas constituintes do revestimento (Disponível em: https://www.aprovaconcursos.com.br/questoes-de-concurso/questao/211692). ........8

Figura 3. Listagem de defeitos $x$ ensaios destrutivos (Fonte: Elaborado pelo autor).

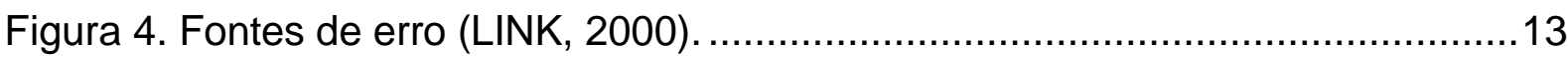

Figura 5. Lei de evolução de custos ou Lei de Sitter (SILVA, 2007). .......................15

Figura 6. (a) Fio de prumo posicionado na fachada (DIOGO, 2007); (b) Pontos de leitura para o mapeamento da fachada com fio de prumo (BARROS, 2001)............18

Figura 7. Esquema de Varredura 360ำ (Fonte: T1 Engenharia)

Figura 8. (a) Ilustração de uma nuvem de pontos, capturada pelo escâner (Fonte: T1 Engenharia); (b) modelo 3D processado a partir da nuvem de pontos capturada pelo escâner.

Figura 9. Comprimento de onda 1: Raio X; 2: UV; 3: Visível; 4: Infravermelho; 5: Microondas; 6: Ondas de Rádio (Fonte: Manual do usuário FLIR T6 series, página 117). 25

Figura 10. Mecanismo de transmissão de calor em fachadas (Adaptado de VALÉRIO, 2007, p. 7) 28

Figura 11. Ilustração de radiação incidênte $(W)$, radiação refletida $(\rho W)$, radiação absorvida $(\alpha W)$ e radiação transmitida $(\tau W)$ (Fonte: Measurement in thermography).

Figura 12. (a) Campo de visão - FOV; (b) Campo de visão instantâneo - IFOV (Fonte: Manual do usuário FLIR).

Figura 13. Relação Alvo x Área Sensoriada (AS). (Fonte: Manual do usuário FLIR). 
Figura 14. Quantidade de pixel cobrindo o objeto (Fonte: Manual do usuário FLIR).33

Figura 15. Propagação de um pulso de calor em um material: (a) Um impulso de energia é aplicado à superfície; (b) O pulso de calor viaja dentro do material e encontra um defeito; (c) O defeito reflete parcialmente e transmite parcialmente o pulso (Adaptado de HOLST, 2000).

Figura 16. Escâner SURPHASER 25HSX (Fonte: T1 Engenharia). 40

Figura 17. Esquema de varredura 360ำ (Fonte: T1 Engenharia Digital). .40

Figura 21. (a) Imagem da obra com detalhe da fachada avaliada e da tela fachadeira; (b) Esquemático da localização do escâner em relação ao prédio. (Fonte: Elaborado pelo autor).

Figura 22. (a) Distância do escâner em relação à fachada; (b) $1^{\circ}$ Plano de referência; (c) Planos simulando diferentes espessuras de argamassa (5 mm - azul / $10 \mathrm{~mm}$ vermelho / $15 \mathrm{~mm}$ amarelo / $20 \mathrm{~mm}$ - verde / $25 \mathrm{~mm}$ - cinza) e paralelos ao $1^{\circ}$ plano de referência. (Fonte: Elaborado pelo autor).

Figura 23. (a) Detalhe do ponto mais externo da fachada no Plano 0'; (b) Ilustração dos planos a $5 \mathrm{~mm}$ (azul), $15 \mathrm{~mm}$ (amarelo) e $25 \mathrm{~mm}$ (cinza) em relação ao plano (vermelho) traçado a partir do ponto mais externo da fachada. (Fonte: Elaborado pelo autor).

Figura 24. Detalhes da câmara térmica T-650 (Fonte: Flir). .46

Figura 25. (a) Imagem do drone e acessórios utilizados; (b) Imagem do drone próximo à fachada (Fonte: Elaborado pelo autor).

Figura 26. Etapas de moldagem dos painéis.

Figura 27. (a) Pórticos metálicos; (b) Painéis executadas com as alvenarias em tijolo cerâmico e bloco de concreto (Fonte: Elaborado pelo autor).

Figura 28. (a) Identificação lateral do painel; (b) Identificação frontal do painel (Fonte: Elaborado pelo autor). 
Figura 29. Ilustração dos quadrantes em cada painel (Fonte: Elaborado pelo autor).

Figura 30. Criação de defeitos reais na alvenaria de bloco cerâmico e concreto: (a) defeito de fissura na argamassa de assentamento da alvenaria no painel PCE1; (b) ausência de argamassa de assentamento na junta vertical da alvenaria. (Fonte: Elaborado pelo autor) .................................................................................

Figura 31. llustração esquemática da criação de vazios na interface entre alvenaria e reboco (Fonte: Elaborado pelo autor). .52

Figura 32. Posicionamento e fixação dos defeitos nos painéis de acordo com o plano de ensaio: (a) PCO2-A e B; (b) PCE2-A e B; (c) PCO3-A; (d) PCE3-A e B. (Fonte: Elaborado pelo autor). 53

Figura 33. (a) Fixação dos limitadores de espessura de argamassa de regularização nos painéis de alvenaria; (b) detalhe. (Fonte: Elaborado pelo autor). .53

Figura 34. Identificação de data de fabricação, volume de água de mistura e lote de fabricação, volume de água de mistura e lote de fabricação da argamassa de projeção utilizada na moldagem dos CPs (Fonte: Elaborado pelo autor). .54

Figura 35. (a) Gráfico de distribuição discreta e (b) Gráfico de distribuição acumulada (Fonte: Elaborado pelo autor) .55

Figura 36. (a) Misturador de argamassa por batelada; (b) Projetor de argamassa. (Fonte: Elaborado pelo autor). .56

Figura 37. Sequência de aplicação de argamassa de projeção sobre parede sem defeitos (Fonte: Elaborado pelo autor). .57

Figura 38. (a) Sequência de aplicação de argamassa de projeção em duas camadas sobre parede com diferentes tipos de defeitos; (b) Régua H. (Fonte: Elaborado pelo autor).

Figura 39. (a) Defeito de desplacamento aplicado sobre a alvenaria; (b) Aplicação de camada de argamassa de projeção sobre o defeito para evitar o escorrimento ou desplacamento da argamassa. (Fonte: Elaborado pelo autor) 
Figura 40. Aquecimento de metade de uma das faces do painel para criar fissuras de retração no reboco: (a) vista frontal do painel térmico; (b) vista posterior do painel térmico; (c) vista do painel após aquecimento. (Fonte: Elaborado pelo autor).

Figura 41. Sequência de assentamento de revestimento cerâmico no painel PCE3-A: (a) início do assentamento; (b) final do assentamento; (c) após rejuntamento. (Fonte: Elaborado pelo autor). 59

Figura 42. Sequência de assentamento de revestimento cerâmico no painel PCE3-B: (a) execução de vazio quadrado de $200 \times 200 \mathrm{~mm}$ sob o revestimento cerâmico; (b) execução da segunda fiada; (c) painel sem rejunte. (Fonte: Elaborado pelo autor)..59

Figura 43. Sequência de assentamento de revestimento cerâmico no painel PCO3-A: (a) Início do assentamento; (b) detalhe de defeitos circulares de $100 \mathrm{~mm}$ e $50 \mathrm{~mm}$ de diâmetro e defeito quadrado de $500 \mathrm{~mm}$ de lado; (c) painel rejuntado. (Fonte: Elaborado pelo autor). 60

Figura 44. Sequência de assentamento de revestimento cerâmico no painel PCO3-B: (a) detalhe de defeitos vazios de argamassa; (b) detalhe de defeito após aplicação (c) painel rejuntado. (Fonte: Elaborado pelo autor).

Figura 45. Detalhamento do painel térmico: (a) frente; (b) lateral; (c) fundo; (d) quadro de energia. (Fonte: Elaborado pelo autor). .63

Figura 46. (a) Área de uso do painel térmico; (b) Distância entre painel e superfície dos painéis. (Fonte: Elaborado pelo autor). .64

Figura 47. (a) Detalhe do isolamento lateral do painel térmico; (b) Detalhamento da posição do painel térmico em relação às paredes e isolamento térmico superior. (Fonte: Elaborado pelo autor) .64

Figura 48. (a) Painel de resfriamento; (b) Detalhamento do bico aspersor de água; (c) Detalhamento da alimentação de água do painel de resfriamento. (Fonte: Elaborado pelo autor). 65

Figura 49. (a) Detalhe da haste de madeira que mantém as paredes a uma distância fixa do painel de resfriamento; (b) Visão do conjunto painel PCO2 e painel de 
resfriamento. (Fonte: Elaborado pelo autor).

Figura 50. (a) Ilustração do painel PCE1-A sem defeitos; (b) Ilustração do painel PCE1-B com a localização de defeitos de fissuras na argamassa de assentamento de alvenaria (linhas vermelhas). (Fonte: Elaborado pelo autor).

Figura 51. (a) llustração do painel PCO1-A com a localização das juntas verticais de assentamento da alvenaria sem argamassa e do defeito de descolamento (isopor); (b) llustração do painel PCO1-B com a localização das juntas verticais de assentamento da alvenaria sem argamassa. (Fonte: Elaborado pelo autor). 68

Figura 52. Ilustração com a localização dos defeitos de descolamento na interface alvenaria/reboco no painel: (a) PCE2-A; (b) PCE2-B. (Fonte: Elaborado pelo autor). 69

Figura 53. Ilustração com a localização dos defeitos de descolamento na interface alvenaria / reboco no painel: (a) PCO2-A; (b) PCO2-B. (Fonte: Elaborado pelo autor).

Figura 54. Ilustração com a localização dos defeitos de descolamento na interface reboco / cerâmica no painel: (a) PCE3-B; (b) PCO3-A. (Fonte: Elaborado pelo autor).

Figura 55. llustração com a localização dos defeitos de vazios de argamassa (quadros s/ a marcação "X") na interface reboco/cerâmica no painel: (a) PCE3-A; (b) PCO3-B. (Fonte: Elaborado pelo autor)..... .70

Figura 56. Esquema ilustrativo de sobreposição de defeitos de descolamentos sob o reboco (linhas vermelhas pontilhadas) e descolamentos de cerâmica (quadros sem a marcação "X") no painel: (a) PCE3-A; (b) PCO3-B. (Fonte: Elaborado pelo autor)...71

Figura 57. Esquema ilustrativo de sobreposição de defeitos de descolamento sob o reboco (linhas vermelhas pontilhadas) e vazios sob o revestimento cerâmico (figuras delimitadas por linhas pretas e números) no painel: (a) PCE3-B; (b) PCO3-A. (Fonte: Elaborado pelo autor). .71

Figura 58. (a) Distância entre painel e câmera térmica; (b) Enquadramento da imagem 
térmica nos limites internos do pórtico. (Fonte: Elaborado pelo autor). .73

Figura 59. Referencias no piso do laboratório para posicionamento dos painéis. (Fonte: Elaborado pelo autor).

Figura 60. Medição de temperatura e umidade ambiente. (Fonte: Elaborado pelo autor).

Figura 61. Posicionamento do painel na área externa do laboratório. (Fonte: Elaborado pelo autor).

Figura 62. (a) Termograma do drone; (b) Imagem digital do drone. (Fonte: Elaborado pelo autor).

Figura 63. (a) Representação do afastamento do escâner em relação à fachada; (b) Representação da área de escaneamento da fachada em relação à capacidade do escâner e volume de varredura com 25 metros de raio (Fonte: Elaborado pelo autor).

Figura 64. Redução da área de sombreamento da fachada em função da distância do escâner em relação à fachada do prédio (Fonte: Elaborado pelo autor).

Figura 65. (a) Uso de pranchas elevatórias (Fonte: Elaborado pelo autor) e (b) hastes saindo para a fachada como recurso para reduzir as áreas de sombreamento (Fonte: T1 Engenharia Digital)

Figura 66. Imagem escaneada da fachada gerada pelo software. (Fonte: T1 Engenharia Digital)

Figura 67. (a) Imagem do primeiro plano de referência gerado pelo software e identificação das vigas; (b) Pontos críticos de irregularidade em $100 \%$ da área da fachada escaneada vs os pontos sob o fio de prumo; (c) Escala de cores. (Fonte: T1 Engenharia Digital).

Figura 68. Imagem dos planos paralelos ao 1ํ plano de referência a uma distância de: (a) $5 \mathrm{~mm}$; (b) $10 \mathrm{~mm}$; (c) $15 \mathrm{~mm}$; (d) $20 \mathrm{~mm}$; (e) $25 \mathrm{~mm}$ (Fonte: T1 Engenharia Digital). 
Figura 69. Planos traçados a partir do $2^{\circ}$ plano de referência. (Fonte: T1 Engenharia Digital).

Figura 70. (a) Termograma de painel em alvenaria de bloco de concreto na condição de baixo gradiente térmico; (b) Ilustração de regulagem de foco. (Fonte: Elaborado pelo autor).

Figura 71. (a) Imagem do Painel PCO1-B com juntas verticais de assentamento da alvenaria preenchidas e não preenchidas com argamassa; (b) Termograma do painel PCO1-B rebocado na condição de baixo gradiente térmico. (Fonte: Elaborado pelo autor).

Figura 72. Termograma de painel PCE1-B em alvenaria de tijolo cerâmico na condição de baixo gradiente térmico. (Fonte: Elaborado pelo autor).

Figura 73. (a) Termograma de painel PCE1-A em alvenaria de tijolo cerâmico rebocado na condição de baixo gradiente térmico; (b) Termograma do painel PCO1 A em alvenaria de bloco de concreto rebocado na condição de baixo gradiente térmico. (Fonte: Elaborado pelo autor)

Figura 74. (a) Termograma de fissuras visíveis a olho nu no painel PCE1-B na condição de baixo gradiente térmico; (b) Imagem de fissuras na junta de assentamento da alvenaria no painel PCE1-B. (Fonte: Elaborado pelo autor). .92

Figura 75. (a) Termograma de fissuras do painel PCE2-B na condição de baixo gradiente térmico; (b) Indicação das fissuras visíveis a olho nu no painel PCE2-B. (Fonte: Elaborado pelo autor) .93

Figura 76. (a) Termograma da superfície rebocada do painel PCE2-A na condição de baixo gradiente térmico; (b) Indicação dos defeitos sob o reboco no painel PCE2-A. (Fonte: Elaborado pelo autor) .93

Figura 77. (a) Termograma da superfície rebocada do painel PCO2-A na condição de baixo gradiente térmico; (b) Indicação dos defeitos sob o reboco no painel PCO2-A. (Fonte: Elaborado pelo autor). .93

Figura 78. (a) Termograma da superfície revestida com cerâmica do painel PCO3-A 
na condição de baixo gradiente térmico; (b) llustração dos defeitos de descolamento sob o revestimento cerâmico do painel PCO3-A. (Fonte: Elaborado pelo autor). .....94

Figura 79. (a) Termograma da superfície revestida com cerâmica do painel PCE3-B na condição de baixo gradiente térmico; (b) llustração dos defeitos de descolamento sob o revestimento cerâmico do painel PCE3-B. (Fonte: Elaborado pelo autor).......94

Figura 80. (a) Termograma da superfície revestida com cerâmica do painel PCO3-B na condição de baixo gradiente térmico; (b) llustração dos defeitos de vazios de argamassa de assentamento sob o revestimento cerâmico do painel PCO3-B. (Fonte: Elaborado pelo autor).

Figura 81. (a) Termograma do painel PCE2-A com grupos de defeitos destacados; (b) Defeitos sob o reboco no painel PCE2-A. (Fonte: Elaborado pelo autor). .96

Figura 82. Área de manchas térmicas devido a imperfeições de acabamento (triângulo), diferenças de rugosidade da argamassa (retângulo), áreas com diferentes tonalidades da própria argamassa (setas brancas) observados no painel PCE2-A. (Fonte: Elaborado pelo autor) .96

Figura 83. Termograma do painel PCE2-A: (a) 65 minutos após início do resfriamento; (b) Após aquecimento. (Fonte: Elaborado pelo autor).

Figura 84. (a) Termograma do painel PCE2-A noventa minutos após início do resfriamento; (b) defeitos inseridos sob reboco. (Fonte: Elaborado pelo autor) .98

Figura 85. Termograma do painel PCE2-A sessenta minutos após iniciado o resfriamento. (Fonte: Elaborado pelo autor). 99

Figura 86. Termograma do painel PCO2-A após início do resfriamento: (a) Seis horas após; (b) Oito horas após; (c) Dez horas após; (d) Doze horas após; (e) Quatorze horas após; (f) Dezesseis horas após. (Fonte: Elaborado pelo autor). 99

Figura 87. (a) Defeitos sob o reboco no painel PCO2-A (b) Termograma do painel PCO2-A logo após aquecimento; (c) Termograma do painel PCO2-A durante resfriamento. (Fonte: Elaborado pelo autor). 100

Figura 88. (a) Termograma do painel PCE2-A imediatamente após resfriamento 
forçado com água: (b) Termograma do painel PCO2-A imediatamente após resfriamento forçado com água. (Fonte: Elaborado pelo autor). 100

Figura 89. (a) Termograma do painel PCE2-A quinze minutos após resfriar com água: (b) Termograma do painel PCO2-A quarenta minutos após resfriar com água. (Fonte: Elaborado pelo autor). 101

Figura 90. (a) Termograma do painel PCE2-A 25 minutos após resfriamento forçado com água: (b) Defeitos sob o reboco no painel PCE2-A. (Fonte: Elaborado pelo autor). 103

Figura 91. (a) Termograma do painel PCO2-A 45 minutos após resfriamento forçado com água: (b) Defeitos sob o reboco no painel PCO2-A. (Fonte: Elaborado pelo autor). 103

Figura 92. Termograma do painel PCO2-A após início do resfriamento forçado: (a) quatro horas após; (b) cinco horas após; (c) seis horas após; (d) sete horas após; (e) oito horas após; (f) nove horas após. (Fonte: Elaborado pelo autor). 104

Figura 93. Termograma do painel PCE2-A após início do resfriamento forçado: (a) quatro horas após; (b) cinco horas após; (c) seis horas após; (d) sete horas após; (e) oito horas após; (f) nove horas após. (Fonte: Elaborado pelo autor). 105

Figura 94. (a) Termogramas do painel PCE2-A no início do aquecimento ao sol; (b) Defeitos sob o reboco no painel PCE2-A; (c) Termogramas do painel PCE2-A 5 minutos após o início do aquecimento ao sol. (Fonte: Elaborado pelo autor). 107

Figura 95. Termogramas do painel PCE2-A após o início do aquecimento ao sol: (a) 10 minutos após; (b) 30 minutos após. (Fonte: Elaborado pelo autor). 107

Figura 96. Termogramas do painel PCE2-A após o início do aquecimento ao sol: (a) 60 minutos após; (b) 120 minutos após; (c) 180 minutos após. (Fonte: Elaborado pelo autor). 108

Figura 97. (a) Termogramas do painel PCO2-A no início do aquecimento ao sol; (b) Defeitos sob o reboco no painel PCO2-A; (c) Termogramas do painel PCO2-A 5 minutos após o início do aquecimento ao sol. (Fonte: Elaborado pelo autor). 109 
Figura 98. Termogramas do painel PCO2-A após o início do aquecimento ao sol: (a) 10 minutos após; (b) 30 minutos após. (Fonte: Elaborado pelo autor).

Figura 99. Termogramas do painel PCO2-A após o início do aquecimento ao sol: (a) 60 minutos após; (b) Defeitos sob o reboco no painel PCO2-A; (c) Travamento interno do bloco. (Fonte: Elaborado pelo autor).

Figura 100. Termograma do painel PCO2-A após início do resfriamento: (a) Imediatamente após; (b) Cinco minutos após; (c) Quinze minutos após; (d) 25 minutos após; (e) trinta minutos após; (f) 35 minutos após; (g) 45 minutos após; (h) 65 minutos após; (i) Quatorze horas e dez minutos após. (Fonte: Elaborado pelo autor). 111

Figura 101. Termograma do painel PCE2-A após início do resfriamento: (a) imediatamente após; (b) cinco minutos após; (c) quinze minutos após; (d) quarenta minutos após; (e) cinco horas após; (f) sete horas após. (Fonte: Elaborado pelo autor).

Figura 102. Termogramas do painel PCO2-A: (a) aquecimento através de painel térmico; (b) aquecimento através do sol. (Fonte: Elaborado pelo autor). 114

Figura 103. (a) Termograma do painel PCE3-B com grupos de defeitos destacados; (b) Defeitos de descolamento sob o revestimento cerâmico no painel PCE2-B. (Fonte: Elaborado pelo autor). 115

Figura 104. (a) Termograma do painel PCO3-A com grupos de defeitos destacados; (b) Defeitos de descolamento sob o revestimento cerâmico no painel PCO3-A. (Fonte: Elaborado pelo autor). 115

Figura 105. (a) Termograma do painel PCE3-A com grupos de defeitos destacados; (b) Defeitos de vazios de assentamento sob o revestimento cerâmico no painel PCE2A. (Fonte: Elaborado pelo autor). 116

Figura 106. (a) Termograma do painel PCO3-B com grupos de defeitos destacados; (b) Defeitos de vazios de assentamento sob o revestimento cerâmico no painel PCO2B. (Fonte: Elaborado pelo autor). 116

Figura 107. (a) Termograma do painel PCE3-B após 15 minutos do início do 
resfriamento; (b) Termograma do painel PCE3-B após 45 minutos do início do resfriamento; (c) Defeitos de descolamento sob o revestimento cerâmico no painel PCE3-B. (Fonte: Elaborado pelo autor).

Figura 108. (a) Termograma do painel PCO3-A após 15 minutos do início do resfriamento; (b) Termograma do painel PCO3-A após 45 minutos do início do resfriamento; (c) Defeitos de descolamento sob o revestimento cerâmico no painel PCO3-A. (Fonte: Elaborado pelo autor).

Figura 109. (a) Termograma do painel PCE3-A após 15 minutos do início do resfriamento; (b) Termograma do painel PCO3-B após 15 minutos do início do resfriamento. (Fonte: Elaborado pelo autor). 118

Figura 110. (a) Termograma do painel PCE3-B após 80 minutos do início do resfriamento; (b) Defeitos de vazios de assentamento sob o revestimento cerâmico no painel PCE3-B. (Fonte: Elaborado pelo autor).

Figura 111. (a) Termograma do painel PCO3-A após 80 minutos do início do resfriamento; (b) Defeitos de vazios de assentamento sob o revestimento cerâmico no painel PCO3-A. (Fonte: Elaborado pelo autor). 119

Figura 112. Termograma do painel PCO3-A após início do resfriamento: (a) duas horas após; (b) três horas após; (c) quatro horas após; (d) cinco horas após; (e) seis horas após; (f) sete horas após. (Fonte: Elaborado pelo autor). 119

Figura 113. Termograma do painel PCO3-B após início do resfriamento: (a) duas horas após; (b) três horas após; (c) quatro horas após; (d) cinco horas após; (e) seis horas após; (f) sete horas após. (Fonte: Elaborado pelo autor). 120

Figura 114. Termograma do painel PCE3-B após do início do resfriamento: (a) 90 minutos após; (b) 210 minutos após; (c) 330 minutos após. (Fonte: Elaborado pelo autor). 120

Figura 115. Termograma do painel PCO3-A após do início do resfriamento: (a) 90 minutos após; (b) 210 minutos após; (c) 330 minutos após. (Fonte: Elaborado pelo autor). 121 
Figura 116. (a) Termograma do painel PCO3-A sem rejuntamento logo após aquecimento; (b) Termograma do painel PCO3-A com rejuntamento logo após aquecimento. (Fonte: Elaborado pelo autor).

Figura 117. (a) Termograma do painel PCO3-A sem rejuntamento durante resfriamento natural; (b) Termograma do painel PCO3-A com rejuntamento durante resfriamento natural. (Fonte: Elaborado pelo autor). 122

Figura 118. (a) Termograma do painel PCO3-B sem rejuntamento logo após aquecimento; (b) Termograma do painel PCO3-B com rejuntamento logo após aquecimento. (Fonte: Elaborado pelo autor). 122

Figura 119. (a) Termograma do painel PCO3-B sem rejuntamento durante resfriamento natural; (b) Termograma do painel PCO3-B com rejuntamento durante resfriamento natural. (Fonte: Elaborado pelo autor). 122

Figura 120. Termograma do painel PCE3-A sem rejuntamento: (a) imediatamente após aquecimento; (b) 70 minutos após início do resfriamento natural. (Fonte: Elaborado pelo autor).

Figura 121. (a) Termograma do painel PCO3-A sem rejuntamento após 12 horas de resfriamento natural; (b) Termograma do painel PCO3-A com rejuntamento após 8 horas de resfriamento natural. (Fonte: Elaborado pelo autor). 123

Figura 122. (a) Termograma do painel PCE2-B imediatamente após resfriamento forçado com água: (b) Termograma do painel PCE2-A imediatamente após resfriamento forçado com água. (Fonte: Elaborado pelo autor). 124

Figura 123. (a) Termograma do painel PCO2-A imediatamente após resfriamento forçado com água: (b) Termograma do painel PCO2-B imediatamente após resfriamento forçado com água. (Fonte: Elaborado pelo autor). 124

Figura 124. Termograma do painel PCO3-A: (a) Melhor definição dos defeitos durante arrefecimento natural; (b) Após arrefecimento forçado com água; (c) Logo após aquecimento. (Fonte: Elaborado pelo autor). 125

Figura 125. Termograma do painel PCO3-B: (a) Melhor definição dos defeitos durante 
arrefecimento natural; (b) Após arrefecimento forçado com água; (c) Logo após aquecimento. (Fonte: Elaborado pelo autor).

Figura 126. Termograma do painel PCE3-B: (a) Melhor definição dos defeitos durante arrefecimento natural; (b) Após arrefecimento forçado com água; (c) Logo após aquecimento. (Fonte: Elaborado pelo autor).

Figura 127. Termograma do painel PCE3-B após resfriamento forçado com água: (a) uma hora após; (b) duas horas após; (c) três horas após; (d) quatro horas após; (e) cinco horas após; (f) seis horas após. (Fonte: Elaborado pelo autor). 126

Figura 128. Termograma do painel PCE3-A após resfriamento forçado com água: (a) uma hora após; (b) duas horas após; (c) três horas após; (d) quatro horas após; (e) cinco horas após; (f) seis horas após. (Fonte: Elaborado pelo autor).

Figura 129. (a) Termograma do painel PCO3-A no início do aquecimento; (b) Termograma do painel PCO3-A após 5 minutos do início do aquecimento; (c) Defeitos de desplacamento sob o revestimento cerâmico no painel PCO3-A. (Fonte: Elaborado pelo autor).

Figura 130. (a) Termograma do painel PCO3-A no início do aquecimento; (b) Defeitos de desplacamento sob o revestimento cerâmico no painel PCO3-A. (Fonte: Elaborado pelo autor). 129

Figura 131. Termograma do painel PCO3-A durante aquecimento ao sol: (a) 30 minutos de aquecimento; (b) 60 minutos de aquecimento; (c) 95 minutos de aquecimento. (Fonte: Elaborado pelo autor). 129

Figura 132. Termograma do painel PCO3-A após início do resfriamento: (a) 60 minutos após; (b) 90 minutos após; (c) 210 minutos após; (d) 330 minutos após; (e) 510 minutos após; (f) 960 minutos após. (Fonte: Elaborado pelo autor).

Figura 133. Painel PCO3-A: (a) Termograma dos defeitos de descolamento sob o reboco (b) llustração dos defeitos sob revestimento cerâmico; (c) Ilustração da sobreposição de defeitos. (Fonte: Elaborado pelo autor) 132

Figura 134. Sobreposição de defeitos no painel PCO3-A: (a) Imediatamente após o 
aquecimento com painel térmico; (b) Menor gradiente térmico registrado durante resfriamento ambiente; (c) Durante aquecimento ao sol. (Fonte: Elaborado pelo autor).

Figura 135. Painel PCO3-B: (a) Termograma dos defeitos de descolamento sob o reboco (b) Ilustração dos defeitos sob revestimento cerâmico; (c) Ilustração da sobreposição de defeitos. (Fonte: Elaborado pelo autor).

Figura 136. Sobreposição de defeitos no painel PCO3-B: (a) Imediatamente após o aquecimento com painel térmico; (b) Menor gradiente térmico registrado durante resfriamento ambiente; (c) Durante resfriamento forçado com água. (Fonte: Elaborado pelo autor). 133

Figura 137. Painel PCE3-A: (a) Termograma dos defeitos de descolamento sob o reboco (b) Ilustração dos defeitos sob revestimento cerâmico; (c) llustração da sobreposição de defeitos. (Fonte: Elaborado pelo autor).

Figura 138. Sobreposição de defeitos no painel PCE3-A: (a) Imediatamente após o aquecimento com painel térmico; (b) Menor gradiente térmico registrado durante resfriamento ambiente. (Fonte: Elaborado pelo autor). 134

Figura 139. Painel PCE3-B: (a) Termograma dos defeitos de descolamento sob o reboco (b) Ilustração dos defeitos sob revestimento cerâmico; (c) Ilustração da sobreposição de defeitos. (Fonte: Elaborado pelo autor). 135

Figura 140. Sobreposição de defeitos no painel PCE3-B: (a) Imediatamente após o aquecimento com painel térmico; (b) Menor gradiente térmico registrado durante resfriamento ambiente; (c) Durante resfriamento forçado com água. (Fonte: Elaborado pelo autor).

Figura 141. (a) Imagem da fachada com defeitos mapeados; (b) Ampliação de parte da fachada com defeitos; (c) Termogramas dos defeitos. (Fonte: Elaborado pelo autor).

Figura 142. (a) Imagem da fachada com defeitos mapeados; (b) Ampliação de parte da fachada com defeitos; (c) Termogramas dos defeitos; (d) Imagem digital dos defeitos. (Fonte: Elaborado pelo autor) 
Figura 143. Termograma de área recém recuperada (setas brancas). (Fonte: Elaborado pelo autor).

Figura 144. (a) Termograma de fachada com regiões recuperadas. (Fonte: Elaborado pelo autor).

Figura 145. Termograma de fachadas após recuperação de descolamento de revestimento cerâmico: (a) em escala de cor "iron"; (b) em escala cinza. (Fonte: Elaborado pelo autor). 139

Figura 146. Termograma de região ainda não recuperada. (Fonte: Elaborado pelo autor). 139

Figura 147. (a) Imagem digital da fachada avaliada; (b) Termograma da fachada avaliada; (c) Termograma da fachada avaliada registrado de outro ângulo; (d) Termograma dos defeitos registrado com drone. (Fonte: Elaborado pelo autor) ....140

Figura 148. (a) Termograma com melhor ajuste de foco para identificação dos defeitos; (b) termograma sem ajuste correto de foco. (Fonte: Elaborado pelo autor).

Figura 149. Fachada com área restrita de incidência solar (quadro branco) devido ao sombreamento causado por prédios vizinhos. (Fonte: Elaborado pelo autor). 142

Figura 150. (a) Detalhe da fachada sob influência de reflexão devido à interferência da arquitetura (face oposta) (b) Influência da reflexão na temperatura superficial. (Fonte: Elaborado pelo autor) 142

Figura 151. (a) Fachada com elevado gradiente térmico entre região com e sem defeito; (b) Mesma fachada em condição de menor gradiente térmico. (Fonte: Elaborado pelo autor). 143

Figura 152. (a) Termograma do defeito de descolamento na fachada avaliada; (b) Isolamento do defeitos com uso de amplitude de temperatura específica ao defeito. (Fonte: Elaborado pelo autor)

Figura 153. (a) Termograma do defeito de desplacamento na fachada avaliada; (b) Zoom dos defeitos. (Fonte: Elaborado pelo autor). 
Figura 154. (a) Termograma do defeito de desplacamento na fachada avaliada; (b) Isolamento dos defeitos com uso de faixa de temperatura específica em imagem ampliada com zoom. (Fonte: Elaborado pelo autor)

Figura 155. Termograma de fachada recuperada com diferentes paletas de cores: (a) Paleta de cor "iron"; (b) Paleta de cor "cinza"; (c) Paleta de cor "ice". (Fonte: Elaborado pelo autor).

Figura 156. Termograma do painel PCO2-A imediatamente após o aquecimento. (Fonte: Elaborado pelo autor) 146

Figura 157. Painel PCO2-A: (a) Imagem digital após resfriamento com água; (b) Termograma imediato após o primeiro resfriamento com água; (c) Termograma cinco minutos após o primeiro resfriamento com água. (Fonte: Elaborado pelo autor)....146

Figura 158. Termogramas do Painel PCO2-A: (a) dez minutos após o resfriamento com água; (b) quinze minutos após o resfriamento com água; (c) vinte minutos após o resfriamento com água. (Fonte: Elaborado pelo autor).

Figura 159. Termogramas de fissuras do Painel PCE2-B após aquecimento com painel térmico: (a) Imediatamente após aquecimento; (b) 45 minutos após aquecimento; noventa minutos após aquecimento. (Fonte: Elaborado pelo autor). 147

Figura 160. Termogramas de fissuras do Painel PCO2A após aquecimento com painel térmico e resfriamento com água: (a) 100 minutos após (início da visualização das fissuras), (b) 190 minutos após (momento de melhor visualização das fissuras), (c) 480 minutos após (fim da visualização dos defeitos). (Fonte: Elaborado pelo autor).

Figura 161. Painel PCE2-A: (a) Imagem digital da fissura presente no canto superior direto do painel; (b) Termograma quinze minutos após o aquecimento; (c) Termograma quarenta minutos após o aquecimento. (Fonte: Elaborado pelo autor).

Figura 162. Termograma da microfissura presente no canto superior direto do painel PCE2-A: (a) cinco minutos após início do aquecimento ao sol; (a) noventa minutos após início do aquecimento ao sol. (Fonte: Elaborado pelo autor) 148 
Figura 163. (a) Imagem digital de fissura na fachada ocultada pelo revestimento e pela distância; (b) Termograma da fissura. (Fonte: Elaborado pelo autor). 149

Figura 164. (a) Imagem digital de fachada fissurada não visível a olho nu; (b) Termograma da fachada fissurada. (Fonte: Elaborado pelo autor). 149

Figura 165. Imagens com uso de drone: (a) Fissuras nos cantos das janelas, caraterísticas de falhas na execução da contraverga; (b) Termogramas das fissuras de canto de janela. (Fonte: Elaborado pelo autor). 150 



\section{ÍNDICE DE TABELAS}

Tabela 1. Elementos de fachada associados ao sistema de revestimento, composição e principais funções (Adaptado de ANTUNES, 2010).

Tabela 2. Evolução do escâner laser 3D (Fonte: Elaborado pelo autor). 19

Tabela 3. Uso de êscaner laser 3D - equipamento vs precisão (ZHANG; ARDITI, 2013). .20

Tabela 4. Características da Câmera Térmica T-640 (Fonte: Flir). .46

Tabela 5. Tabela de planejamento de moldagens das paredes (Fonte: Elaborado pelo autor). .50

Tabela 6. Características padrão para cada etapa experimental (Fonte: Elaborado pelo autor). 62

Tabela 7. Resumo de resultados dos planos traçados a partir do $1^{\circ}$ plano de referência em relação à imagem escaneada. (Fonte: Elaborado pelo autor) .84

Tabela 8. Resultados a partir do $2^{\circ}$ plano de referência (Fonte: Elaborado pelo autor). .86

Tabela 9. Volumes vs custos da argamassa nos diferentes planos de estudo (Fonte: Elaborado pelo autor). .88 



\section{INTRODUÇÃO}

A evolução do setor da construção civil tem provocado a industrialização do canteiro de obras através de soluções que aumentam a produtividade e simplificam o processo executivo, compondo um balanço custo vs prazo que pressiona a redução do tempo de obra e retorno dos investimentos.

Esta relação implica a alteração gradativa de técnicas construtivas rudimentares por modernas, associada aos riscos de incompatibilidades entre os sistemas e à permanência de técnicas de controle com significativa variabilidade, ambas consequências naturais do processo de transição (BARROS, 2001).

Um exemplo prático é o revestimento de fachada, fundamental na proteção e durabilidade das edificações e que, ao ter sua etapa de volumetria alterada por erros intrínsecos ao processo de controle geométrico da estrutura de concreto através da técnica imprecisa e restritiva do fio de prumo, sofre um aumento potencial no consumo de materiais, do tempo e da mão de obra em relação ao planejado, e/ou dos riscos de defeitos variados (BARROS, 2001; VEIGA, 2005).

Como parte desse contexto, o índice de problemas em revestimentos tem sido elevado, principalmente no que se refere à aderência argamassa/substrato (descolamento/desplacamento) e fissuração, geralmente motivados por falhas na execução. O desplacamento, em particular, constitui um problema social por causar vítimas devido à queda de material da fachada e ambos geram prejuízos econômicos a construtores, fabricantes de insumos e usuários (COSTA, 2007; ALVES, 2009).

Para realizar o levantamento e diagnóstico dos defeitos em revestimentos, as técnicas de ensaio mais utilizadas têm sido as destrutivas, chamadas assim por necessitarem de intervenções diretas que danificam o local analisado, porém alguns desses ensaios apresentam elevada variabilidade e imprecisão, além de baixa confiabilidade quando utilizados como indicadores de durabilidade e qualidade dos revestimentos (COSTA, 2007).

Como fator agravante, apesar de muitos desses defeitos serem visualmente identificáveis, existem aqueles ocultos cuja detecção visual é inviável (MAZER, 2011). A condição de ocultação traz uma série de potenciais problemas até sua identificação, 
como a progressão e o agravamento do defeito, manifestação de outros defeitos, podendo dificultar ou até mesmo inviabilizar técnica e/ou economicamente o diagnóstico pelas técnicas tradicionais e a recuperação em alguns casos extremos.

Eliminar esses riscos por meio de técnicas capazes de atuar de forma não destrutiva na prevenção/correção de falhas durante a execução dos revestimentos ou na identificação dos defeitos ocultos antes do agravamento do problema é fator crítico para evitar prejuízos ao desempenho técnico dos materiais aplicados e na vida útil das edificações, refletindo diretamente na sustentabilidade dos projetos (GALVÃO, 2009).

Nesse contexto, o desenvolvimento de equipamentos de escaneamento 3D laser com capacidade de leituras de grandes superfícies - como fachadas -, fornecendo medidas exatas e confiáveis, ampliou a possibilidade de aplicação dessa tecnologia no setor da construção civil de forma reconhecida para diferentes finalidades em todo o ciclo de vida de um edifício, incluindo a detecção de erros cometidos durante a construção e a comparação entre o consumo de materiais previsto em projeto e o efetivamente consumido na obra (ZHANG; ARDITI, 2013; XIONG et al., 2013).

Na mesma linha, a termografia infravermelha com dispositivos portáteis de resposta rápida e sem necessidade de contato com a superfície analisada permite localizar e identificar áreas de perda de calor causadas por diferentes elementos de construção ou por defeitos construtivos. Atualmente esta técnica vem sendo usada de forma eficaz indicando e acompanhando áreas com cavidades e separações em camadas de superfície, juntas não preenchidas em alvenaria, umidade, entre outros. (KAUPPINEN et al., 1999; GOMES, 2006; BARREIRA; FREITAS, 2005; AVDELIDIS; MOROPOULOU, 2002). Além disso, existem algumas potencialidades do uso da tecnologia de termografia para fachadas que ainda não estão completamente exploradas, tais como a detecção de degradação em materiais de revestimento em fachadas, especialmente microfissuras (BARREIRA, E. et al., 2014).

Assim, com o objetivo de atuar nos problemas expostos, dentre as opções de ensaios não destrutivos (END) existentes, a presente dissertação considerou para o estudo as técnicas não destrutivas de escaneamento 3D laser e de termografia infravermelha. 


\subsection{OBJETIVO}

Esta dissertação de mestrado encontra-se inserida no Programa de Pós-Graduação em Engenharia Civil e Urbana da Escola Politécnica da Universidade de São Paulo (PCC-EPUSP) e faz parte do Consórcio Setorial para Inovação da Tecnologia de Revestimentos de Argamassa (CONSITRA 2), tendo como objetivo:

- verificar a viabilidade de uso do escaneamento 3D laser para mapear a planicidade da fachada e quantificar o volume de argamassa como uma solução precisa e eficaz voltada à redução do consumo, sem passar necessariamente pelo maior controle geométrico da estrutura e vedações.

- analisar o potencial da termografia como técnica de controle in situ por meio do estudo de precisão, de abrangência e de velocidade na identificação e no mapeamento de defeitos ocultos nos revestimentos de fachadas após sua execução e em uso.

\subsection{Estrutura da Dissertação}

Para melhor organização e entendimento da dissertação foi adotada a seguinte estruturação:

- Introdução: contextualiza o cenário favorável ao uso dos ensaios não destrutivos estudados e apresenta os objetivos do estudo.

- Revisão da Literatura: apresenta os principais aspectos da bibliografia referentes aos defeitos de fissura e descolamento no revestimento de fachada e métodos atuais para diagnosticá-los, às interferências do controle geométrico da estrutura no consumo de argamassa e aos ensaios não destrutivos de escaneamento 3D laser e termografia infravermelha necessários ao entendimento do trabalho.

- Metodologia: nele são descritas as variáveis de estudo, os materiais utilizados na pesquisa, bem como os métodos adotados. 
- Resultado: contém a discussões e as considerações específicas para cada uma das duas técnicas de ensaios não destrutivos proposta, complementada pelo item matérias no caso da termografia. Foi segmentada em duas partes, tema dos artigos:

> Parte I - Uso do escaneamento 3D laser para análise de planicidade e volumetria de argamassa em fachadas: Um estudo de caso sobre a aplicação inovadora da tecnologia consolidada de escaneamento 3D laser em fachada de edifício após a execução da alvenaria, por meio da análise dos modelos 3D gerados por softwares de mercado.

Parte II - Potencial da tecnologia de termografia infravermelha na identificação de defeitos de fachadas: Um estudo realizado em três etapas experimentais.

- Etapa de Laboratório: verificar a capacidade da termografia na identificação de defeitos de descolamento/vazios e fissuras com diferentes dimensões e formas, gerados/simulados na alvenaria, no revestimento de argamassa e no revestimento cerâmico por meio de uma abordagem de aquecimento ativa e de resfriamento natural ou forçado.

- Campo: esta fase do trabalho teve como objetivo aplicar a técnica de termografia nos mesmos moldes da etapa de Laboratório, porém, sob a incidência direta de sol (abordagem passiva de aquecimento) e resfriamento natural sujeito a vento, fatores que podem interferir na qualidade e na precisão da leitura térmica. Os resultados obtidos foram comparados aos da etapa de Laboratório.

- In situ: verificar a capacidade de a termografia atuar como ferramenta de diagnóstico de defeitos de descolamento e fissuras no revestimento de argamassa e descolamento de revestimentos cerâmicos em fachadas, identificar influências intrínsecas ao processo de uso da tecnologia em ambiente aberto sob a incidência direta de sol e resfriamento natural e levantar as influências do uso de recursos do equipamento na visualização 
dos defeitos. Estudo de caso comparando o mapeamento de descolamento cerâmico realizado com a técnica de "percussão" com a termografia.

- Conclusões: apresenta as principais conclusões dessa dissertação, salientando aspectos relacionados à aplicabilidade do escaneamento 3D laser e da termografia para o uso proposto, além de sugestões para próximos trabalhos.

- Referências Bibliográficas 


\section{REVISÃO BIBLIOGRÁFICA}

\subsection{Desempenho}

$O$ atendimento à condição de desempenho das edificações no Brasil ganha importância gradual por meio da Norma Brasileira de Desempenho de Edifícios Habitacionais - NBR 15575 como meio para garantir qualidade, conforto, manutenabilidade e durabilidade das edificações.

A NBR 15575-1 (ABNT, 2013) define desempenho como o "comportamento em uso de um edifício habitacional e dos sistemas que o compõe" e, para atingí-lo, estabelece patamares mínimos para assegurar condições adequadas de uso, parâmetros voltados ao mercado para redução de não conformidades, papéis e responsabilidades mais claras do projeto à manutenção.

Os requisitos de desempenho conforme a NBR 15575-1 (ABNT, 2013) são qualitativos em relação ao que se deseja dos elementos e componentes do edifício, e os critérios de desempenho são a quantificação dos requisitos que visam representar tecnicamente as exigências do usuário (ANTUNES, 2010).

\subsection{Durabilidade/Vida Útil}

Dentre as diferentes definições de durabilidade relacionadas à construção civil, a ASTM E632-82 (1996) considera durabilidade a capacidade de um produto, componente, montagem ou construção de manter-se em serviço ou em utilização, ou de desempenhar as funções para as quais foi projetado durante um determinado período de tempo.

A durabilidade está intimamente ligada à vida útil da edificação, já que, segundo a norma NBR 5674, ela consiste no intervalo de tempo ao longo do qual a edificação atende aos requisitos funcionais de projeto desde que atendidos os planos de operação, uso e manutenção (ABNT, 2012).

A durabilidade e o desempenho das fachadas dependem do cumprimento de decisões tomadas no processo que vão da etapa de projeto dos edifícios, passando pela construção e indo até a manutenção, todas sob a interferência dos materiais 
aplicados, mão de obra utilizada e controles adotados, levando a uma série de atividades programadas que prolongam a vida útil da edificação (CONSOLI, 2006).

\subsection{Sistema de Revestimento de Fachada}

Quando se pensa no conceito de revestimento externo, segundo a NBR 13755 (ABNT, 1996), naturalmente tem-se a ideia de conjunto - formado por camadas superpostas (estrutura suporte, alvenarias, camadas sucessivas de argamassas e revestimento final), intimamente ligadas e suscetíveis à influência umas das outras em razão de suas diferentes propriedades e comportamentos -, cuja função é proteger a edificação de fatores externos associados a diferentes tipos de solicitações e dar acabamento estético.

No caso dos sistemas de revestimento de fachada, os cuidados devem receber atenção especial já que há uma carga extra de intensidade dos fatores externos incidentes sobre ele, tal como ilustrados na Figura 1. Vale ressaltar que o revestimento é parte integrante das vedações verticais e este depende das características da camada de ancoragem, das propriedades da argamassa e do substrato (CINCOTTO, 1995; COSTA, 2007).

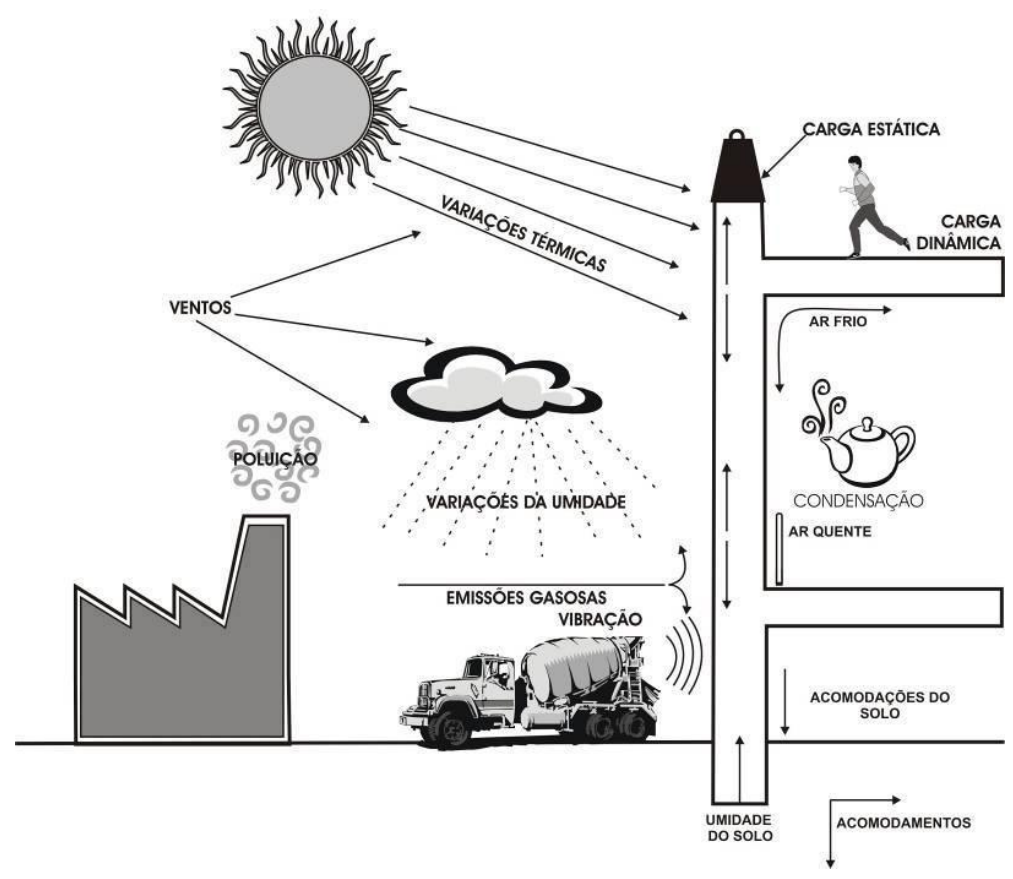

Figura 1. Representação esquemática dos agentes atuantes em sistema de revestimento de argamassa (SELMO, 1989). 
Os elementos da fachada (Figura 2) associados ao sistema de revestimento, suas composições e respectivas funções são apresentados na Tabela 1, adaptada de ANTUNES (2010) onde foram compilados dados de Medeiros e Sabbatini (1999) e da NBR 13755 (ABNT, 1996).

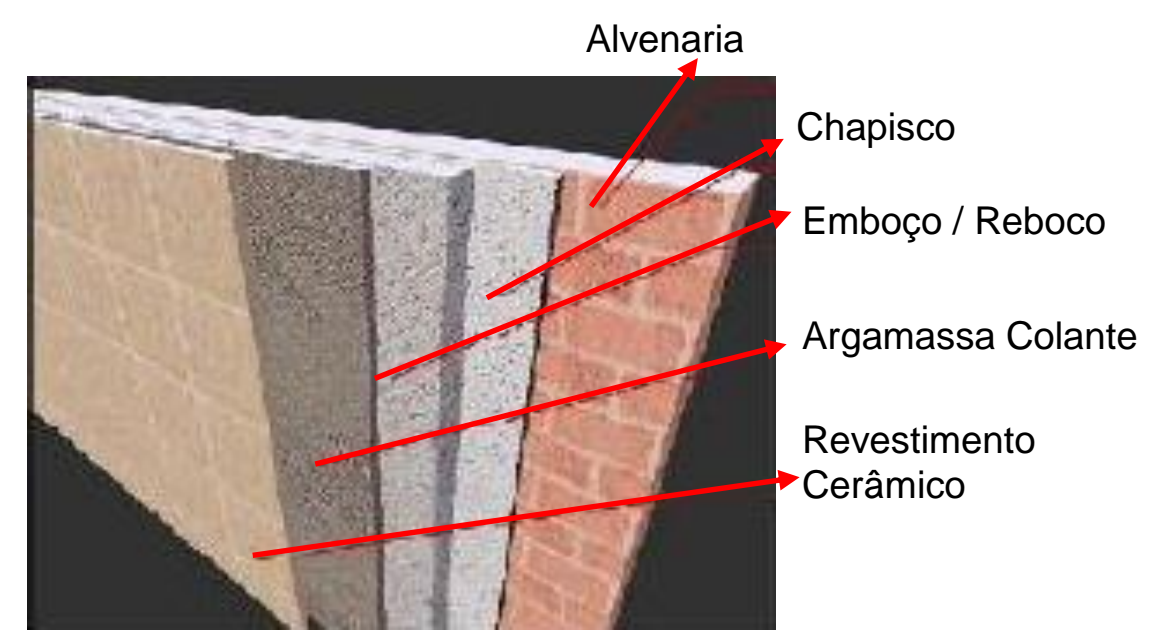

Figura 2. Camadas constituintes do revestimento (Disponível em: https://www.aprovaconcursos.com.br/questoes-de-concurso/questao/211692).

As fachadas dos edifícios são compostas por revestimentos de diferentes tipos. Neste trabalho, serão considerados como foco de estudo:

- revestimento de argamassa cimentícia, em que a norma NBR 13749 (ABNT, 2013) recomenda para emboço em parede externa espessuras entre 20 e 30 $\mathrm{mm}$;

- revestimento cerâmico, definido pela NBR 13816 (ABNT, 1997) como o conjunto formado pela placa cerâmica, pela argamassa de assentamento e pelo rejunte, em que a norma NBR 14081 (ABNT, 2012) recomenda o uso de no mínimo argamassa adesiva tipo AC-II no assentamento de revestimento cerâmico de fachada, e a norma NBR 14992 (ABNT, 2003) prevê as argamassas de rejuntamento tipos I e II, classificadas de acordo com o local de aplicação e características, estando a tipo II mais adequada à fachada. 
Tabela 1. Elementos de fachada associados ao sistema de revestimento, composição e principais funções (Adaptado de ANTUNES, 2010).

\begin{tabular}{|c|c|c|}
\hline Elemento da fachada & Composição & Função \\
\hline Base ou substrato & $\begin{array}{l}\text { Constituído por superfície plana de } \\
\text { parede, podendo ser de concreto } \\
\text { armado ou alvenaria de bloco: } \\
\text { cerâmico, concreto, concreto celular } \\
\text { ou sílico calcário. }\end{array}$ & $\begin{array}{l}\text { vedação ou estrutural / receber o } \\
\text { revestimento de argamassa. }\end{array}$ \\
\hline Chapisco & Argamassa de cimento areia e água. & $\begin{array}{l}\text { Uniformizar a absorção da superfície } \\
\text { da base / melhorar a aderência do } \\
\text { revestimento. }\end{array}$ \\
\hline Emboço & \multirow{2}{*}{$\begin{array}{l}\text { Mistura homogênea de agregado(s) } \\
\text { miúdo(s), aglomerantes(s) } \\
\text { inorgânico(s) e água contendo ou } \\
\text { não aditivos e adições, com } \\
\text { propriedades de aderência e } \\
\text { endurecimento. }\end{array}$} & $\begin{array}{l}\text { Cobrir e regularizar a superfície da } \\
\text { base ou chapisco corrigindo defeitos e } \\
\text { irregularidades da mesma para } \\
\text { receber o reboco ou revestimento } \\
\text { decorativo ou acabamento final. }\end{array}$ \\
\hline Reboco & & $\begin{array}{l}\text { Cobrir o emboço para receber o } \\
\text { revestimento decorativo ou } \\
\text { acabamento final. }\end{array}$ \\
\hline Argamassa colante & $\begin{array}{l}\text { Mistura constituida de agregado } \\
\text { mineral, aglomerantes(s) } \\
\text { hidráulico(s), aditivo(s) e água, } \\
\text { formando uma massa viscosa, } \\
\text { plástica e aderente. }\end{array}$ & Aderir as palcas cerâmicas à base. \\
\hline Acabamento decorativo & $\begin{array}{l}\text { Tinta ou placa cerâmica e } \\
\text { argamassa de rejunte. }\end{array}$ & $\begin{array}{l}\text { Contribuir para a definição estética do } \\
\text { edifício e conferir a fachada resistência } \\
\text { à penetração de água, isolamento, } \\
\text { limpabilidade, entre outros. }\end{array}$ \\
\hline Argamassa de rejunte & $\begin{array}{l}\text { Pode ser argamassa a base de } \\
\text { cimento, areia e/ou outros agregados } \\
\text { finos, inertes com adição de aditivos; } \\
\text { nata de cimento; resina epóxi ou } \\
\text { outro material específico para a } \\
\text { função. }\end{array}$ & $\begin{array}{l}\text { Preencher juntas de assentamento de } \\
\text { placas cerâmicas. }\end{array}$ \\
\hline
\end{tabular}

\subsection{Defeitos em revestimentos de fachada}

Os defeitos são reflexos da queda precoce de desempenho do sistema a um nível crítico e sua origem nos sistemas de revestimentos pode estar relacionada ao componente que o manifesta ou estar vinculado a danos e falhas decorrentes de outros elementos da edificação (ANTUNES, 2010).

Nas edificações, os defeitos podem ser classificados conforme suas origens: os congênitos originários da fase de projeto, os construtivos com origem relacionada à fase de execução da obra, estando associados ou não à falha do material, os 
adquiridos durante a vida útil do edifício e os acidentais caracterizados pela ocorrência de algum fenômeno atípico (PEDRO, 2002).

Normalmente surgem como consequência de diferentes fatores, entre eles estão a degradação por agentes mecânicos, térmicos, biológicos, entre outros; todos promovendo alterações que impactam o desempenho das edificações (CAMPANTE, 2011; JOHN; SATO, 2006). Fissuras de retração e deficiência de aderência são exemplos de defeitos em fachadas causados pela ação conjunta de agentes como chuva, vento e temperatura, sendo esta última considerada a mais agressiva à medida que provoca variações físicas e químicas nos materiais (SOUZA; ALMEIDA, 2005; CONSOLI, 2006).

A utilização crescente de projetos com estruturas reticuladas, esbeltas, com grandes vãos e de elevadas alturas aumentou significativamente as deformações impostas à alvenaria/revestimento, consequentemente também são motivos de ampliação da incidência de defeitos, como a fissuração da argamassa e descolamentos na interface argamassa/substrato (CINCOTTO; SILVA; CARASEK, 1995; CEOTTO; BANDUK; NAKAKURA, 2005).

\subsubsection{Descolamento/Desplacamento}

Descolamentos são falhas ou rupturas na interface das camadas que constituem o revestimento, ou na interface com o substrato, e podem ser causadas quando as tensões atuantes são maiores que a resistência dos materiais que compõem o revestimento ou superam a capacidade de aderência das ligações entre as camadas (BARROS et al., 1997; SARAIVA, 1998).

O desenvolvimento desse tipo de defeito ocorre ao longo do tempo e não está necessariamente condicionado à queda imediata do revestimento de argamassa ou de placas cerâmicas. O defeito inicia com a ruptura na interface entre camadas e formação de bolsões que evoluem ao ponto de instabilizar estruturalmente o sistema de revestimento. A primeira evidência do aparecimento do descolamento é a presença de som oco ou visivelmente por meio do afastamento físico da camada (ANTUNES, 2010; CHAVES, 2009). 
Espessuras excessivas de argamassa (superiores a 3,0 cm) podem, por retração, apresentar tensões elevadas de tração entre a interface argamassa/substrato podendo provocar o descolamento do revestimento. Uma das causas de elevadas espessuras de argamassa é o acúmulo de erros durante o processo executivo. Nesses casos, não sendo possível atender às espessuras admissíveis, devem ser tomados cuidados especiais para garantir a aderência entre as camadas. (BARROS et al., 1997).

Em revestimentos cerâmicos colados o deslocamento pode ser localizado perante deficiências pontuais de aplicação ou do substrato, podendo ter origem em pequenas fissuras, zona de concentração de tensões, entrada de água para o substrato ou quando se utilizam argamassas / argamassas colantes além do tempo de abertura; ou generalizado normalmente associado à elevada expansão dos revestimentos, falta de qualidade do material de colagem, deficiente aplicação ou à incompatibilidade entre as várias camadas do sistema (APICER, 2003).

\subsubsection{Fissuras}

O grau de fissuração é função de vários fatores, mas de modo geral resultam do alívio de tensões entre partes de um elemento ou entre dois elementos em contato. Quando a argamassa é fraca, as tensões podem ser dissipadas através de microfissuração, pois as ligações internas entre agregado e aglomerante são menos resistentes. Ao contrário, na argamassa forte pode ocorrer acúmulos de tensões e consequentemente ruptura através de macrofissuras de forma que as regiões próximas das fissurações podem ter a capacidade de aderência comprometida (CARVALHO, 2005; MEHTA; MONTEIRO, 1994).

Assim, pode-se estabelecer uma relação importante na qual o módulo de deformação juntamente com a resistência de aderência caracteriza a resposta mecânica da argamassa apontando para a propensão à fissuração das argamassas e passam a ser um indicador do grau de hidratação do material.

Pela NBR 9575 (ABNT, 2010) são consideradas fissuras as aberturas ocasionadas por ruptura de um material ou componente e são classificadas como: microfissuras (abertura com espessura inferior a $0,05 \mathrm{~mm}$ ); fissuras (espessura inferior ou igual 0,5 $\mathrm{mm}$ ) e trinca (abertura superior a 0,5 $\mathrm{mm}$ e inferior a $1 \mathrm{~mm}$ ). 


\subsection{Identificação de Defeitos}

As suspeitas da existência de defeitos levam normalmente à execução de ensaios para comprovação e levantamento de sua extensão. Numa análise realizada sobre as técnicas de controle e diagnóstico atualmente praticados em obra identificou-se que a maior parte é do tipo destrutiva conforme detalhado na Figura 3, chamadas assim por necessitar de intervenções que danificam o local analisado.

Observa-se que tanto os métodos de ensaio quanto os processos de medição estão suscetíveis a um grande número de interferências, conforme ilustrado na Figura 4, que direta ou indiretamente direcionam a erros sistemáticos justificando a alta variabilidade e incerteza dos resultados apurados por esses ensaios (LINK, 2000; COSTA, 2007).

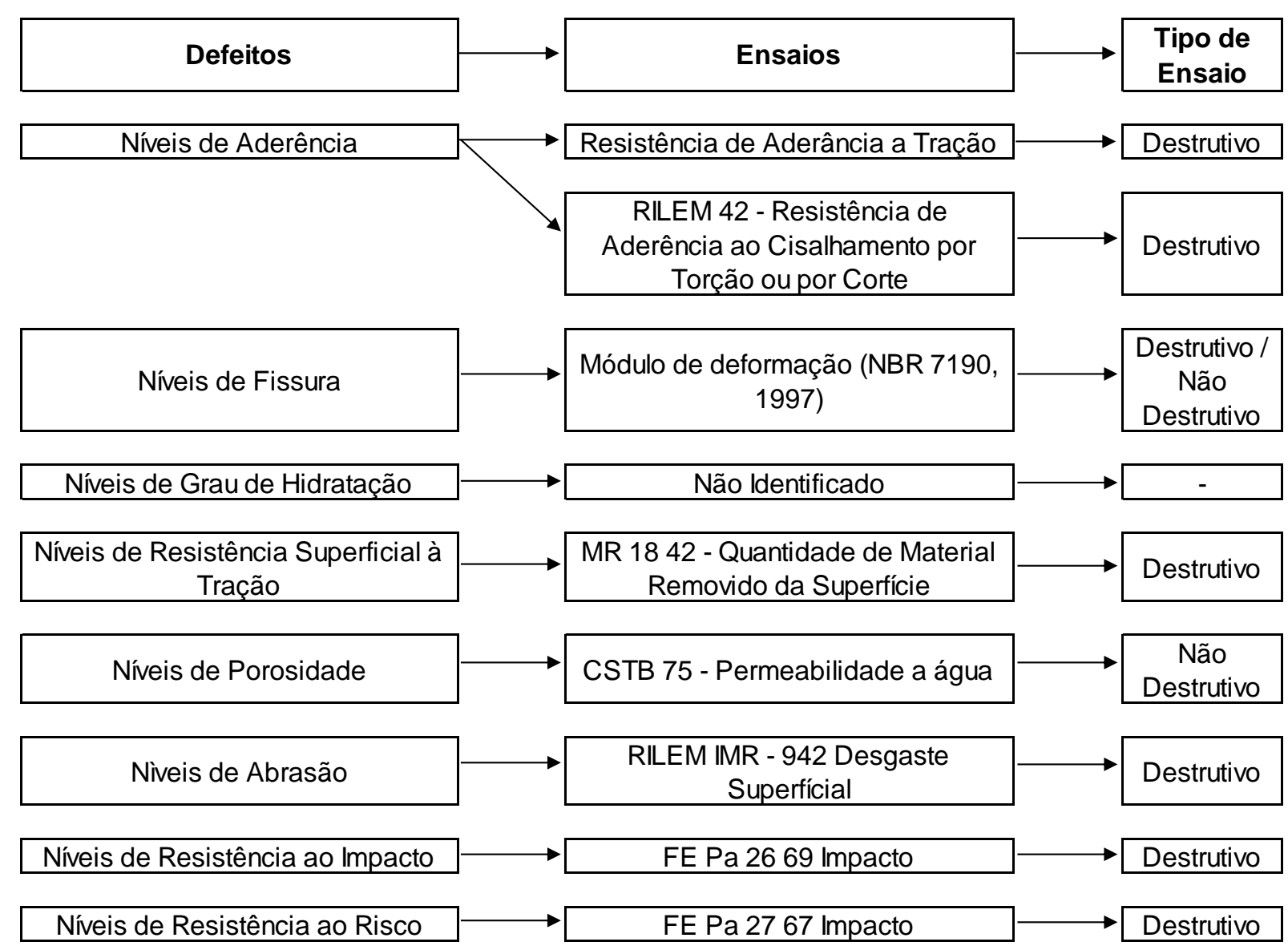

Figura 3. Listagem de defeitos x ensaios destrutivos (Fonte: Elaborado pelo autor). 


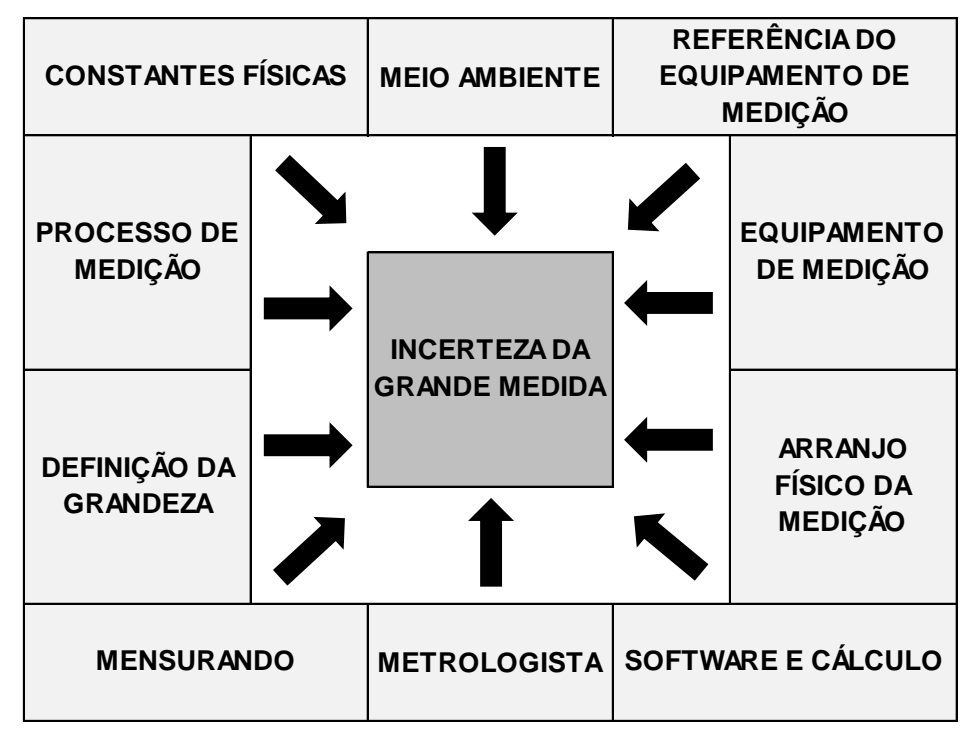

Figura 4. Fontes de erro (LINK, 2000).

Como o objetivo do trabalho é identificar os defeitos de fissura de descolamento no estado endurecido da argamassa, e não suas causas, destacam-se os ensaios de módulo de deformação e de resistência de aderência à tração.

\subsubsection{Módulo de deformação (NBR 7190, 1997)}

Pela lei de Hooke, define-se o módulo de elasticidade como a relação entre a tensão normal e a deformação correspondente, dentro do limite elástico. No sentido restrito do termo, é entendido como a capacidade do material de se deformar sem apresentar ruptura quando sujeito a solicitações diversas e de retornar à dimensão original quando cessam essas solicitações. Para o caso das argamassas, material não elástico, a lei de Hooke é aplicada de forma aproximada e grosseira, podendo ser entendido como o estado tal de deformação (plástica) em que a ruptura ocorre sob a forma de fissuras microscópicas ou capilares não prejudiciais (CINCOTTO, 1995; HAECKER et al., 2005; MACIEL; BARROS; SABBATINI, 1998).

A magnitude das tensões de cisalhamento na interface argamassa/substrato é dada pelo módulo de elasticidade do revestimento de argamassa e da espessura da camada. Quanto maior o módulo de elasticidade maior será o esforço que a interface deverá suportar para um mesmo nível de deformação. Desse modo, a argamassa de revestimento ideal possui baixo módulo de elasticidade (JOHN, 2003). 


\subsubsection{Resistência de aderência à tração}

Representa a máxima tensão que um revestimento suporta quando submetido a um esforço normal de tração; o ensaio consiste na imposição de um esforço de tração perpendicular ao revestimento a ser ensaiado (GONÇALVES, 2004) e é referenciado por duas normas técnicas:

- NBR 13528 (ABNT, 2010) - prescreve o método de ensaio da resistência de aderência à tração para revestimentos de paredes e tetos.

- NBR 13749 (ABNT, 2013) - determina as especificações necessárias aos revestimentos, incluindo os limites mínimos de resultado para este ensaio.

Nos resultados deste tipo de ensaio, fatores como variação da sucção dos substratos e do teor de água das argamassas, processo executivo do revestimento, materiais utilizados, condições climáticas, entre outros geram uma variabilidade intrínseca de 52\% (GONÇALVES, 2004).

Reforçando as questões relacionadas à imprecisão dos resultados, a influência dos esforços cíclicos de diferentes origens na interface argamassa/substrato e na própria argamassa reduz gradualmente a resistência de aderência (JOHN, 2003). Somado a isso, diferentes tipos de tensões atuantes nos revestimentos podem influenciar os resultados de aderência (FIORITO, 1994).

Como agravante, as especificações normativas não prescrevem níveis máximos de resistência de aderência à tração cujos resultados tendem a ser diretamente proporcionais ao módulo de deformação. Assim, quando os valores são altos, traduzse em revestimentos rígidos e com maior grau de fissuração potencial na medida em que possuem maior dificuldade de absorver deformações. Dessa forma, confiar apenas nos resultados deste tipo de ensaios, prática utilizada na maioria das obras, podem trazer informações insuficientes para serem utilizadas como critério de aceitação dos revestimentos, pois elevados valores de resistência de aderência não são, por si só, indicadores de durabilidade e qualidade dos revestimentos. (ARAÚJO, 2004). 


\subsection{Controle Preventivo e Corretivo}

O passar do tempo agrava os defeitos da fachada, dessa forma, como expresso na Lei de Sitter (Figura 5), quanto mais cedo as correções forem planejadas e realizadas, mais duráveis, fáceis de executar e baratas elas serão.

Caso as decisões que impliquem o prolongamento da vida útil de uma fachada forem definidas na fase de execução, e não de projeto, conduzem a um custo cinco vezes mais elevado para se alcançar o mesmo resultado. As operações isoladas de manutenção (preventiva), com o objetivo de assegurar condições favoráveis da fachada durante o seu período de vida útil, podem custar vinte e cinco vezes o valor, se as mesmas fossem consideradas em fase de projeto. Caso a fachada já tenha atingido um nível de desempenho inferior ao definido em projeto, apresentando anomalias claras, será necessária uma intervenção de reparo ou reforço (manutenção corretiva), à qual está associada a um custo cento e vinte e cinco vezes maior do que se as mesmas fossem contempladas na fase de projeto. (CHAVES, 2009).

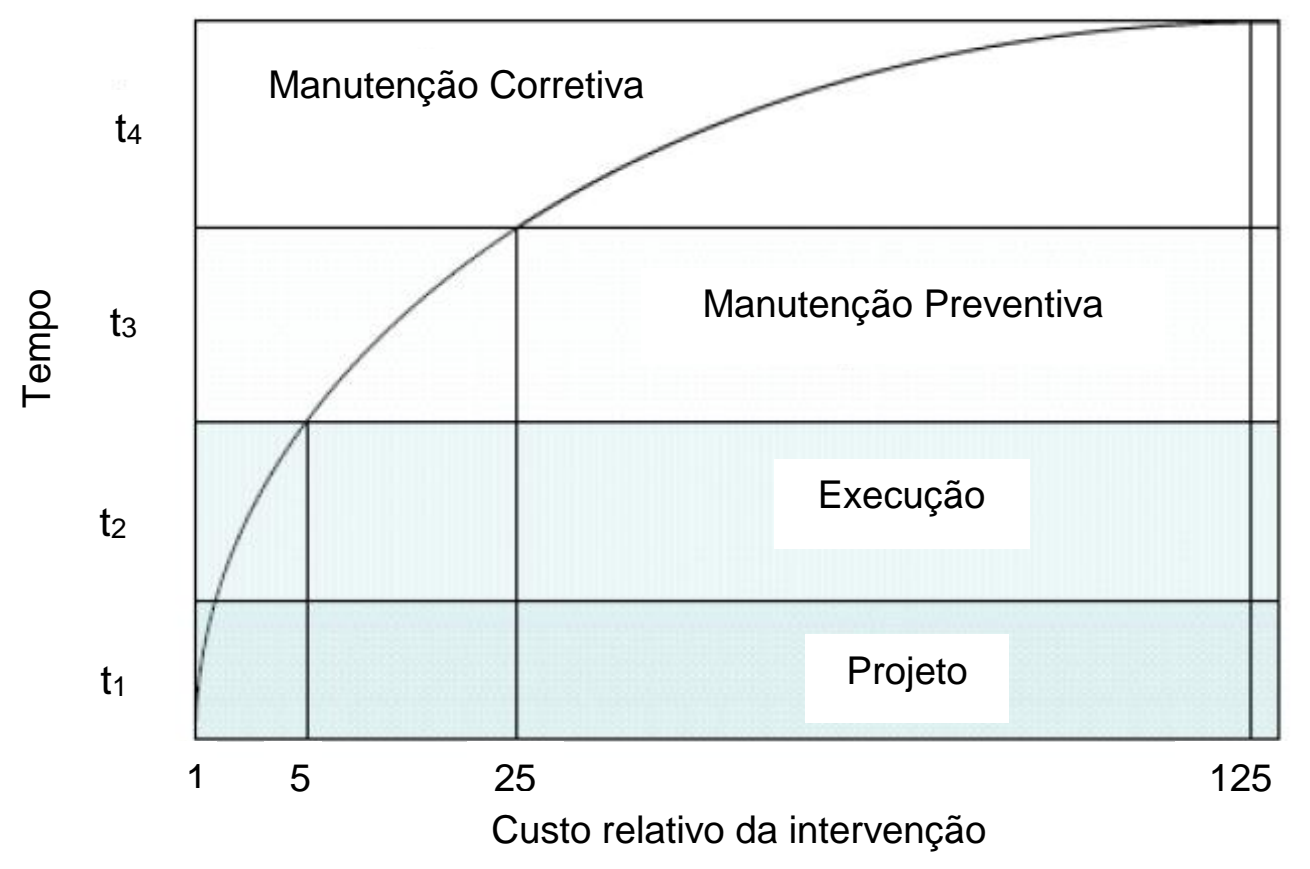

Figura 5. Lei de evolução de custos ou Lei de Sitter (SILVA, 2007).

Como normas de construção por si só não garantem a qualidade dos sistemas e não impedem falhas executivas, pelo menos as partes vitais da construção devem ser acompanhadas de avaliações sistemáticas, para determinar defeitos visíveis e 
ocultos. Assim, garantir à construção durabilidade, conforto e satisfação aos usuários passa a depender não só de um projeto bem estruturado, mas também de outros fatores, como o desenvolvimento das técnicas de controle voltadas às etapas executivas, capazes de acompanhar o novo ritmo dos canteiros com menor interferência, máxima abrangência e confiabilidade dos resultados, proporcionando informações que sinalizem a necessidade de medidas corretivas de forma rápida, contribuindo para o maior controle dos procedimentos técnicos e melhor desempenho das edificações (MEOLA et al., 2005; BARREIRA; FREITAS, 2005).

Para isso, a periodicidade das inspeções, a velocidade e a precisão na identificação dos defeitos são determinantes, pois permitem descobrir as deficiências de construção em um estágio incipiente e realizar a recuperação de forma correta e econômica, enquanto a mão de obra, os materiais e os equipamentos estão prontamente disponíveis na obra, evitando falhas, simplificando o processo e evitando maiores desperdícios relacionados à demolição de etapas subsequentes ou intervenções corretivas pós obra. Com isso, o uso de técnicas auxiliares de diagnóstico, especialmente aquelas in situ, permitem avaliar, com mais precisão, o nível de desempenho das fachadas (MEOLA et al., 2005; BARREIRA et. al, 2004; GALVÃO, 2009).

Assim, o tema controle ganha destaque por representar uma maneira de garantir que cada parte do sistema seja executada corretamente de forma a cumprir integralmente sua função e propiciar o melhor desempenho das etapas subsequentes. Nessa linha, os ensaios não destrutivos possuem representativo potencial para manutenção preventiva e corretiva, possibilitando avaliar o comportamento dos materiais aplicados sem danificá-los, permitindo a repetição do ensaio no mesmo local ou em local muito próximo com baixa ou nenhuma interferência na obra viabilizando um constante monitoramento e o acompanhamento de variações ao longo do tempo, características em linha com a nova necessidade e expectativa do setor construtivo. (BARREIRA; FREITAS, 2004).

\subsection{Impacto do Controle Geométrico da Estrutura de Concreto}

Apesar de o controle geométrico estar presente em todas as fases de construção do edifício e representar uma ferramenta importante na racionalização construtiva, ainda 
não é executado integral e corretamente em boa parte das edificações no Brasil (COSTA, 2005; BARROS, 2001). Dessa forma, falhas no método de controle geométrico da estrutura reduzem a assertividade para o cálculo do volume de argamassa, aumentam a dificuldade para corrigir e agir de forma efetiva na melhoria da espessura final do revestimento de argamassa, além de gerar defeitos.

As influências na regularização de fachadas têm como um dos fatores críticos 0 controle geométrico das superfícies de pilares e fachadas pelo fio de prumo, técnica rudimentar utilizada para aferir $o$ alinhamento e nivelamento das fôrmas de concretagem de cada pavimento e entre pavimentos, e também para referenciar o mapeamento das espessuras de argamassa na fachada após a execução da alvenaria (BARROS, 2001).

Construído com arames presos em uma das extremidades a hastes metálicas ou de madeira alocadas na cobertura da edificação e na outra ponta fixo a pesos normalmente feitos de corpo de prova de concreto ou lata de tinta preenchida com concreto para tencionar o fio de arame e garantir o alinhamento conforme ilustrado na Figura 6-a, sua tolerância para desvios $( \pm 15 \mathrm{~mm})$ é a maior entre as demais técnicas para aferir a verticalidade considerada pela norma ISO 7976-1 (BARROS, 2001).

A pouca abrangência em relação à área mapeada, aproximadamente $30 \%$ do número de paredes externas em cada pavimento, e sua imprecisão fazem com que o uso do fio de prumo resulte no desalinhamento entre os pavimentos e consequentemente na falta de esquadro e de prumo da estrutura de concreto e alvenaria. Essa condição favorece o acúmulo de erros e levam a variações nas espessuras médias do revestimento de argamassa da fachada (Figura 6-b), que vão de $26 \%$ a $73 \%$ (COSTA, 2005; OLIVEIRA, et al., 1995).

Como consequência, as espessuras abaixo do intervalo de $2 \mathrm{~cm}$ a $3 \mathrm{~cm}$, indicadas pela NBR13749 (ABNT, 2013) para revestimentos externos, podem transformar-se em pontos frágeis que provocarão defeitos de descolamentos/desplacamentos e fissuras, comprometendo a função protetora do revestimento, enquanto as sobrespessuras, além de representarem perdas de material que variam de $6 \%$ a $39 \%$, potencializam os riscos dos defeitos citados e de cargas adicionais na estrutura (COSTA, 2005). As sobrespessuras são consideradas em muitos estudos como um dos maiores fatores 
de desperdícios de argamassa (PICCHI, 1993; PALIARI et al., 1999; AGOPYAN et al., 1998; SOIBELMAN, 1993).

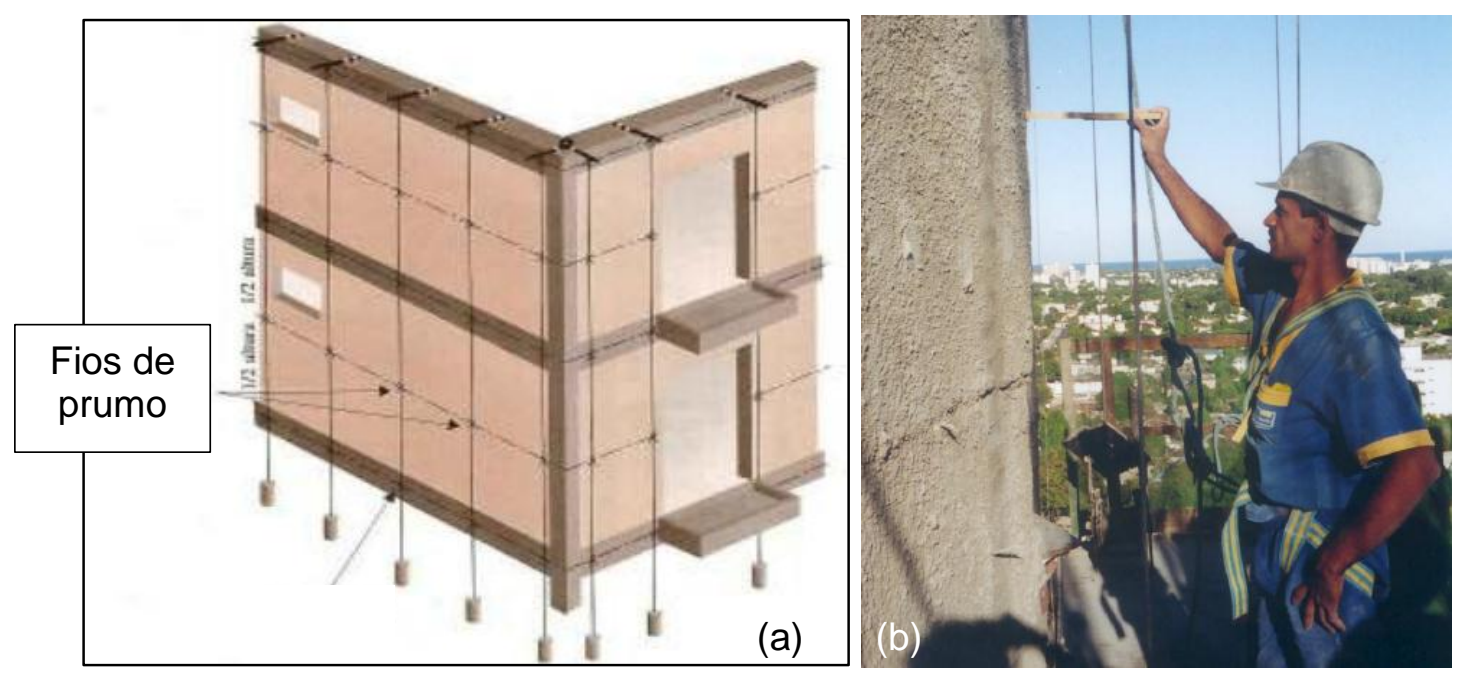

Figura 6. (a) Fio de prumo posicionado na fachada (DIOGO, 2007); (b) Pontos de leitura para o mapeamento da fachada com fio de prumo (BARROS, 2001).

\subsection{Princípio básico do escaneamento 3D laser}

O escaneamento 3D laser é uma tecnologia de medição e digitalização remota de alta precisão e detalhamento nos levantamentos tridimensionais, proporcionando baixo erro em relação aos métodos tradicionais, traduzida na realização de projetos de especial complexidade técnica em diferentes áreas, como engenharia, arquitetura e infraestruturas (Disponível em: <http://en.wikipedia.org/wiki/3D_scanner>. Acesso em: 28 mar. 2015).

O nome se deu pelo uso do laser para medições lineares e pelo uso da varredura (escâner) horizontal e vertical para medições angulares e pelo fato de armazenar como dado bruto, essencialmente coordenadas $\mathrm{X}, \mathrm{Y}$, e Z (3D), calculadas em tempo real a partir das medições lineares e angulares (Disponível em: <http://mundogeo.com/blog/2013/06/05/evolucao-historica-dos-levantamentos-alaser/>. Acesso em: 28 mar. 2015).

Podemos dividir sua evolução até os dias de hoje em quatro gerações (Tabela 2). 
Tabela 2. Evolução do escâner laser 3D (Fonte: Elaborado pelo autor).

\begin{tabular}{|c|c|c|c|c|c|c|c|}
\hline Geração & Portabilidade & $\begin{array}{c}\text { Frequência } \\
\text { de medição } \\
\text { (pontos } \\
\text { /segundo) }\end{array}$ & $\begin{array}{l}\text { Alcance } \\
\text { (m) }\end{array}$ & $\begin{array}{c}\text { Prisma de } \\
\text { direcionamento } \\
\text { do laser }\end{array}$ & $\begin{array}{l}\text { Velocidade de } \\
\text { Processamento }\end{array}$ & $\begin{array}{l}\text { Trabalhos } \\
\text { em Campo }\end{array}$ & Acessórios \\
\hline 1997 & baixa & 1.000 a 5.000 & 200 & $\begin{array}{c}\text { fixo - limitado a } \\
\text { uma janela, giro } \\
\text { do equipamento } \\
\text { manual para } \\
\text { obter nuvem no } \\
\text { entorno do } \\
\text { equipamento }\end{array}$ & complexo / lento & $\begin{array}{l}\text { limitados - } \\
\text { elevado } \\
\text { tempo para } \\
\text { execução e } \\
\text { quantidade } \\
\text { de dados } \\
\text { gerados }\end{array}$ & \begin{tabular}{|c} 
não \\
integrados - \\
computador \\
para \\
armazena \\
mento e \\
fonte de \\
energia \\
externos \\
\end{tabular} \\
\hline 2000 & baixa & 100.000 & 600 & $\begin{array}{c}\text { giro de } 360 \\
\text { graus na } \\
\text { horizontal }\end{array}$ & complexo / lento & $\begin{array}{l}\text { possíveis - } \\
\text { mineração }\end{array}$ & - \\
\hline 2007 & alta & 500.000 & 2.000 & - & $\begin{array}{c}\text { amigável / produtivo - } \\
\text { integrado }\end{array}$ & $\begin{array}{c}\text { extendido p/ } \\
\text { outras } \\
\text { áreas de } \\
\text { atuação. } \\
\text { Ex: } \\
\text { arquitetura }\end{array}$ & $\begin{array}{c}\text { integrados } \\
\text { (armazena } \\
\text { mento, } \\
\text { bateria e } \\
\text { câmera } \\
\text { fotográfica) }\end{array}$ \\
\hline 2010 & alta & 1.000 .000 & 4.000 & $\begin{array}{c}\text { giro de } 360^{\circ} \text { na } \\
\text { horizontal e } 270^{\circ} \\
\text { na vertical - } \\
\text { câmeras } \\
\text { fotográficas } \\
\text { associadas ao } \\
\text { movimento }\end{array}$ & $\begin{array}{l}\text { amigável / uso de } \\
\text { complexos } \\
\text { algoritmos para } \\
\text { modelagem e } \\
\text { extração ágil de } \\
\text { informações - } \\
\text { processamento de } \\
\text { dados em campo }\end{array}$ & $\begin{array}{c}\text { aplicável } \\
\text { em muitas } \\
\text { áreas de } \\
\text { atuação }\end{array}$ & integrados \\
\hline
\end{tabular}

Na tecnologia ativa, o processo físico do escâner laser ocorre através da emissão de uma fonte de luz (laser) e detecção da reflexão, gerando representações tridimensionais precisas da superfície desse objeto. Os principais escâneres utilizados neste tipo de tecnologia são de três tipos, conforme descrito na Tabela 3 (ZHANG; ARDITI, 2013).

O surgimento de métodos de medição 3D por laser para uma vasta gama de aplicações nos últimos anos (SU; HASHASH; LIU, 2006), estimulado por necessidades específicas, contribuiu para a disponibilização de diferentes tipos de escâneres 3D no mercado (GRYZAGORIDIS, 2012). Associado ao amadurecimento da tecnologia tornou possível a execução de procedimentos no campo em um tempo relativamente curto e, embora os custos de equipamentos (hardware e software) ainda representem uma restrição (SU; HASHASH; LIU, 2006), não é impedimento para suas aplicações em obra. 
Tabela 3. Uso de êscaner laser 3D - equipamento vs precisão (ZHANG; ARDITI, 2013).

\begin{tabular}{|c|c|c|c|c|c|c|c|c|}
\hline \multirow{2}{*}{ Tipo } & \multirow{2}{*}{ Princípio } & \multirow{2}{*}{$\begin{array}{l}\text { Principais } \\
\text { Vantagens }\end{array}$} & \multirow{2}{*}{$\begin{array}{l}\text { Principal } \\
\text { Limitação }\end{array}$} & \multirow{2}{*}{$\begin{array}{l}\text { Precisão } \\
\text { máxima } \\
\text { final em } \\
\text { campo }\end{array}$} & \multirow{2}{*}{$\begin{array}{l}\text { Frequência } \\
\text { de medição } \\
\text { (pontos / } \\
\text { segundo) }\end{array}$} & \multirow{2}{*}{ Alcance } & \multicolumn{2}{|c|}{ Aplicações } \\
\hline & & & & & & & Tipo & Descrição \\
\hline $\begin{array}{c}\text { Time } \\
\text { of } \\
\text { flight }\end{array}$ & \begin{tabular}{|c} 
Medição do \\
tempo no qual o \\
pulso laser \\
emitido leva para \\
retornar ao \\
equipamento \\
para cálculo das \\
distâncias dos \\
pontos do objeto
\end{tabular} & $\begin{array}{l}\text { Longo } \\
\text { alcance }\end{array}$ & $\begin{array}{l}\text { Velocidade } \\
\text { de captura } \\
\text { de dados } \\
\text { baixa - } \\
\text { cálculo de } \\
\text { apenas um } \\
\text { ponto por } \\
\text { vez }\end{array}$ & $10 \mathrm{~cm}$ & $\begin{array}{c}10.000 \sim \\
100.000\end{array}$ & $20 \mathrm{~km}$ & \multicolumn{2}{|c|}{$\begin{array}{c}\text { Eng a civil: levantamentos } \\
\text { topográficos de estradas e } \\
\text { edifícios }\end{array}$} \\
\hline & \multirow[b]{2}{*}{$\begin{array}{c}\text { Medição da } \\
\text { mudança de fase } \\
\text { da luz de laser } \\
\text { para cálculo das } \\
\text { distâncias entre } \\
\text { escâner e objeto }\end{array}$} & \multirow[b]{2}{*}{$\begin{array}{l}\text { Velocidade } \\
\text { de captura } \\
\text { de dados } \\
\text { mais alta }\end{array}$} & \multirow[b]{2}{*}{$\begin{array}{l}\text { Médio } \\
\text { alcance: } \\
<500 \text { m }\end{array}$} & \multirow[b]{2}{*}{$20 \mathrm{~mm}$} & \multirow[b]{2}{*}{ > 1 milhão } & \multirow[b]{2}{*}{$500 \mathrm{~m}$} & \multirow[b]{2}{*}{$\begin{array}{l}\text { Plantas } \\
\text { industriais, } \\
\text { eng }{ }^{\text {a civil ou }} \\
\text { arquitetura }\end{array}$} & $\begin{array}{c}\text { Definição de } \\
\text { espaços }\end{array}$ \\
\hline $\begin{array}{l}\text { Phase } \\
\text { based }\end{array}$ & & & & & & & & $\begin{array}{c}\text { Preenchimento } \\
\text { de modelos } \\
\text { detalhados de } \\
\text { informação de } \\
\text { construção de } \\
\text { instalações } \\
\text { existentes }\end{array}$ \\
\hline $\begin{array}{c}\text { Phase } \\
\text { shift }\end{array}$ & $\begin{array}{l}\text { Pulso sobre a } \\
\text { fase da onda, } \\
\text { associado aos } \\
\text { anteriores. }\end{array}$ & $\begin{array}{c}\text { Máxima } \\
\text { precisão e } \\
\text { menor ruído } \\
\text { (imprecisão) }\end{array}$ & $\begin{array}{l}\text { Curto a } \\
\text { médio } \\
\text { alcance: } \\
<150 \mathrm{~m}\end{array}$ & $0.5 \mathrm{~mm}$ & > 1 milhão & $150 \mathrm{~m}$ & \begin{tabular}{|c|} 
Mecânicas, \\
equipamentos, \\
instalações e \\
plantas \\
industriais, \\
enga civil e \\
arquitetura \\
\end{tabular} & $\begin{array}{l}\text { Sempre que a } \\
\text { precisão e } \\
\text { riqueza de } \\
\text { detalhes tiver } \\
\text { papel mais } \\
\text { relevante. }\end{array}$ \\
\hline
\end{tabular}

Os atuais escâneres aplicados na engenharia civil e arquitetura são os de varredura esférica (Figura 7), compostos pela rotação vertical de um espelho combinada com a rotação horizontal do escâner; assim, o escâner digitaliza todo o seu campo de visão ponto a ponto, mudando a direção do telêmetro, dispositivo de precisão destinado à medição de distâncias em tempo real, porém o telêmetro a laser só detecta a distância de um ponto em sua direção de visão reproduzindo fielmente a distância da origem do escâner até 0 objeto. (Disponível em: <http://en.wikipedia.org/wiki/3D_scanner>. Acesso em: 28 mar. 2015).

O resultado de uma varredura é uma "nuvem de pontos", conjunto de pontos (como um arquivo de dados) em um sistema de coordenadas tridimensional ( $X, Y$ e $Z$ ), representando a superfície externa de objetos (Figura 8-a), que depois de capturados por um escâner a laser pode ser processada e combinada em modelos 3D (Figura 8b) precisos compostos por milhões de pontos, utilizando normalmente um software próprio (SU; HASHASH; LIU, 2006). A densidade dos pontos depende da velocidade com que o laser percorre a superfície. Um escâner a laser pode fornecer uma análise rápida de boa qualidade e precisa, além da detecção da característica de qualquer 
objeto (ZHANG; ARDITI, 2013). Medições de pontos individuais podem ter uma precisão de alguns centímetros ou menos de um milímetro de acordo com o sensor, o intervalo e a superfície que está sendo digitalizada (XIONG et al., 2013).

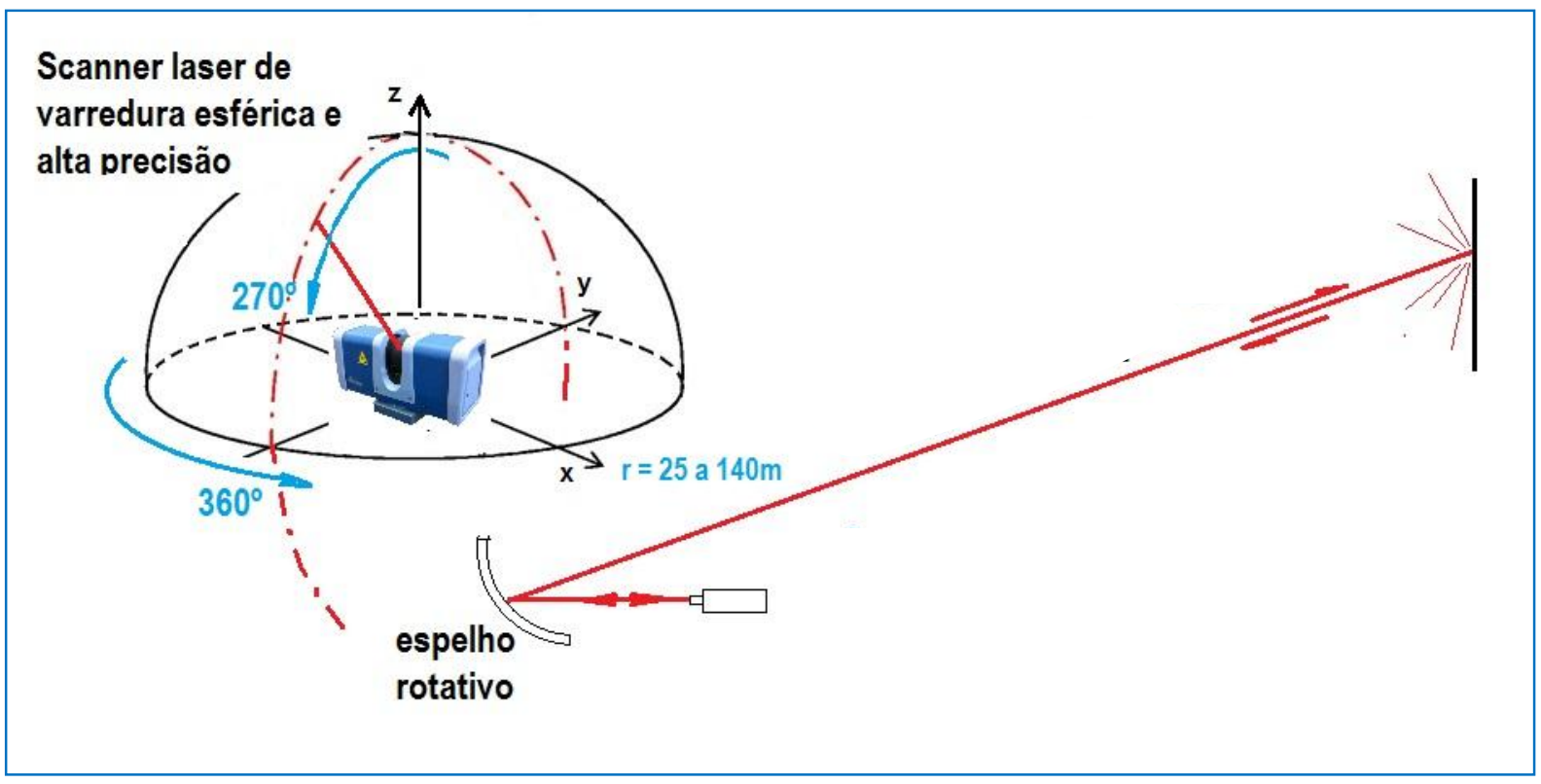

Figura 7. Esquema de Varredura 360ำ (Fonte: T1 Engenharia).

Uma característica única de varredura a laser ao longo do levantamento é a capacidade de manipular e visualizar dados em alta resolução, geralmente sem sofrer limitações pelas condições ambientais durante a operação (GOLPARVARFARD et al., 2011). Mais recentemente, sistemas de digitalização móveis tornaramse disponíveis, reduzindo o tempo de trabalho à custa de alguma precisão da nuvem de pontos registrada. Aplicado às fachadas de um edifício, o método tem como entrada um conjunto de nuvens de pontos, que, levados a um sistema de coordenadas comum - processo normalmente chamado de alinhamento ou de registro - e obtidos a partir de vários pontos da fachada, fundem-se para formar um modelo 3D completo semanticamente rico que contém a informação geométrica e de identidade da fachada (BERNARDINI; RUSHMEIER, 2002; XIONG et al., 2013). 


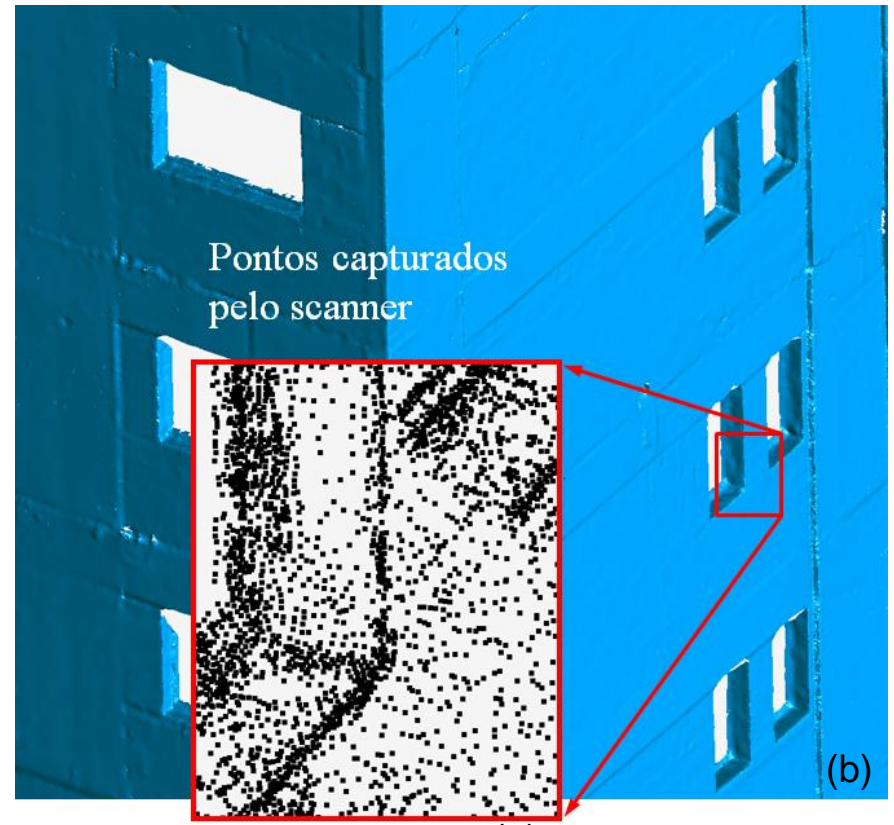

(a)

Figura 8. (a) llustração de uma nuvem de pontos, capturada pelo escâner (Fonte: T1 Engenharia); (b) modelo 3D processado a partir da nuvem de pontos capturada pelo escâner.

Apesar da alta precisão do escâner a laser, um conjunto de limitações e desafios na sua implementação em obras pode reduzir os benefícios observados (GOLPARVARFARD et al., 2011). Essas limitações incluem o fato de só poderem retornar dados de objetos que estão dentro da linha de visão do escâner causando descontinuidade da informação espacial por obstáculos/interferências que impedem a leitura pelo laser (JASELSKIS; GAO, 2003), chamado neste trabalho de zona de sombreamento, podendo criar ocultações no objeto-alvo e até gerar interpretações equivocadas do modelo. Além disso, é dependente de uma série de fatores, incluindo a distância mínima e máxima entre o objeto e o escâner, a refletividade da superfície-alvo, ângulo de medida e tempo para uma varredura completa (AKBARZADEH et al., 2006).

Apesar de a maioria dos trabalhos assumir que as ocultações são mínimas ou que as regiões ocultas de um ponto de vista podem ser observadas a partir de outro (FRUEH et al., 2005, PU; VOSSELMAN, 2009), há muitas soluções propostas para o problema geral de reconstrução de superfícies ocultas em 3D, também conhecido como "preenchimento de buracos" (DAVIS et al., 2002; SALAMANCA et al., 2008). 
Em estudos direcionados para o problema da reconstrução de exteriores de edifícios, usando dados do escâner a laser, por exemplo (FRUEH, et al. 2005), a ênfase, em geral, tem sido na criação de modelos visuais realistas em vez de geometricamente precisos. Por meio de algoritmos extraem-se correções planas a partir dos dados (nuvem de pontos), mas não se reconhecem explicitamente a identidade dos componentes ocultos (XIONG et al., 2013).

\subsection{Princípio básico da termografia infravermelha (TIV)}

A origem da termografia infravermelha volta para o início de 1800, quando William Herschel descobriu a radiação térmica, a luz invisível mais tarde chamada infravermelha. Em meados dos anos 1960, a TIV tornou-se uma técnica de mapeamento de temperatura e durante os últimos anos evoluiu como ferramenta de investigação e controle não destrutivo, sendo capaz de fornecer informação útil para a caracterização de materiais e estruturas em uma ampla gama de aplicações, em que cada campo apresenta características e requisitos específicos que implicam a escolha correta do sistema de infravermelho, o procedimento de teste e a análise de dados (GIORLEO et al., 2002; MEOLA et al., 2003; MEOLA et al., 2005).

O princípio da TIV, uma vez que todo corpo com temperatura acima do Zero Absoluto emite radiação térmica, é transformar esta energia irradiada na faixa infravermelha do espectro electromagnético em uma imagem visível onde cada nível de energia é representado por uma cor ou nível de tonalidade cinza. A TIV se baseia na perturbação do fluxo de calor, gerado interna ou externamente, produzindo desvios na distribuição da temperatura superficial do objeto que são captadas pelos equipamentos termográficos gerando uma imagem (CORTIZO, 2007).

$\mathrm{Na}$ termografia são utilizadas as abordagens passiva e ativa para gerar diferenças de temperatura na superfície sobre as áreas com defeitos ocultos (EDIS et al., 2014).

- Termografia Ativa:

Uma fonte externa de calor é necessária para estimular a temperatura dos materiais a serem inspecionados, e as imagens térmicas são tomadas durante ou após o aquecimento artificial (MALDAGNE, 1992; ROSINA; ROBISON, 2002). 
A termografia ativa, em especial a de arrefecimento, ja é bem estabelecida em ensaios não destrutivos de materiais, como metais, cerâmicas e plásticos. Nesse método, as informações sobre a estrutura em teste são obtidas por meio do aquecimento da superfície da amostra com uma unidade de aquecimento artificial. A duração do impulso de aquecimento pode variar entre segundos e alguns minutos, dependendo da aplicação. O arrefecimento, logo após o aquecimento, é observado por meio de captura de imagens térmicas em intervalos de tempo pré-definidos. A partir do comportamento de arrefecimento em diferentes posições sobre a superfície, as estruturas da região perto da superfície podem ser localizadas quanto a diferenças de condutividade térmica, capacidade de calor específico e densidade (KAUPPINEN, 1999).

- Termografia Passiva

O Fluxo de calor através do material é gerado por condições de contorno naturais, ou seja, os materiais naturalmente estão a uma temperatura diferente do ambiente (MALDAGNE, 1992; GRINZATO et al., 2002).

Estudos recentes sobre a detecção de defeitos por meio da termografia usam principalmente a abordagem ativa, no entanto, apesar de possível, o aquecimento artificial da fachada não é prático em edifícios, já a energia solar como fonte de calor (abordagem passiva) mostrou potencial como técnica preliminar de inspeção para detectar defeitos em revestimentos aderidos, porém o teste termográfico fica condicionado à incidência da radiação solar direta (EDIS et al., 2014).

A abordagem passiva na investigação de edifícios é geralmente uma forma qualitativa de avaliação, cujo objetivo é identificar avarias, porém as leituras corretas de temperatura e os resultados quantitativos nesse tipo de abordagem geralmente só são alcançados com o uso dos valores corretos de emissividade dos materiais. (AVDELIDIS; MOROPOULOU, 2002).

\subsubsection{Energia Infravermelha}

A energia infravermelha é parte do espectro eletromagnético e se comporta de forma semelhante à luz visível. Ele viaja através do espaço à velocidade da luz e pode ser refletida, refratada, absorvida e emitida. O comprimento de onda (L) da energia 
infravermelha é superior à luz visível, entre 0,7 e $1000 \mu \mathrm{m}$ (Figura 9) e por consequência não é visível para os seres humanos, entretanto, ela pode ser notada em forma de calor. O nome significa "abaixo do vermelho", isso se deve ao fato de a cor vermelha ter a menor frequência do espectro de luz visível e o infravermelho ser uma frequência logo abaixo. (BARREIRA et al., 2014).

Porém, quando se trata da tecnologia de termografia apenas a faixa entre 1 e $15 \mu \mathrm{m}$ é utilizada, normalmente nas regiões 2-5 (banda de onda média), 6 e 8-14 $\mu$ m (banda de onda longa). Essas duas bandas espectrais são normalmente utilizadas, por causa da sua baixa absorção atmosférica e por apresentar disponibilidade de dectetores adequados (MALDAGUE, 1993).

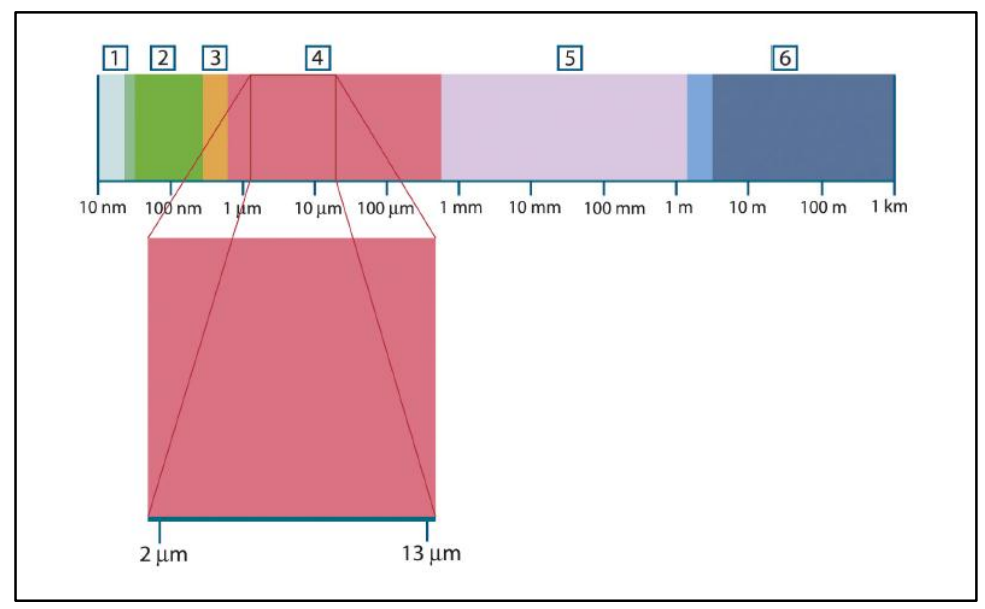

Figura 9. Comprimento de onda 1: Raio X; 2: UV; 3: Visível; 4: Infravermelho; 5: Microondas; 6: Ondas de Rádio (Fonte: Manual do usuário FLIR T6 series, página 117).

\subsubsection{Corpo Negro}

Um corpo negro é uma superfície ideal que absorve toda a radiação incidente sobre ele, independente do comprimento de onda e da direção. O poder emissivo espectral do corpo negro é governado pela distribuição de Planck, ilustrada na equação 1 (GAUSSORGUES,1999):

$$
\frac{d R(\lambda, T)}{d \lambda}=\frac{2 \cdot \pi \cdot h \cdot c^{2} \cdot \lambda^{-5}}{\exp \left(\frac{h \cdot c}{\lambda \cdot k \cdot T}\right)-1}
$$


onde $d R(\lambda, T)$ / $d \lambda$ é o brilho espectral ou poder emissivo por unidade de área do corpo negro e comprimento de onda, $h$ é a constante de Planck $\left(h=6.626176 \times 10^{-34}\right.$ Js), $k$ é a constante de Boltzmann $\left(k=1.380662 \times 10^{-23} \mathrm{~J} / \mathrm{K}\right)$, $c$ é a velocidade da luz ( $c$ $=2.998 \times 108 \mathrm{~m} / \mathrm{s}), \lambda$ é o comprimento de onda $(\mu \mathrm{m})$ e $T$ é a temperatura $(K)$.

\subsubsection{Emissividade}

A propriedade que descreve a relação entre a radiação emitida e a temperatura do material é denominada emissividade $(\varepsilon)$. Ela é calculada (equação 2) pela razão entre a radiação emitida pela superfície do material e a radiação emitida por um corpo negro à mesma temperatura (INCROPERA; WITT, 2001), ou seja, a radiação emitida por um objeto é a radição de um corpo negro multiplicada pela emissividade do objeto (AVDELIDIS; MOROPOULOU, 2002).

$$
\varepsilon(\lambda)=\frac{d R(\lambda, T) / d \lambda}{d R_{c n}(\lambda, T) / d \lambda}
$$

Como se trata de uma propriedade de superfície que prevê a possibilidade de o material emitir energia ela é afetada (BARREIRA, 2004):

- pela temperatura: os materiais neste estudo encontram-se em temperatura ambiente, zona em que a emissividade não altera significativamente.

- pelo comprimento de onda da energia

- pelo ângulo de medição: para não metais, a variação da emissividade é praticamente nula para ângulos entre $0^{\circ}$ e $60^{\circ}$ em relação a perpendicular à superfície.

Por emitirem uma quantidade de radiação variada, superfícies reais não se comportam como um corpo negro que possui $\varepsilon=1$, representando a máxima emissão de radiação, enquanto um objeto $\operatorname{com} \varepsilon=0$ (refletor perfeito - espelho) não emite radiação independente da sua temperatura. Já um objeto que possui $\varepsilon<1$ constante para todos os comprimentos de onda é chamado de corpo cinza (Manual Técnico FLIR, 2009). Uma superfície com uma emissividade baixa (alta refletância), como uma cerâmica esmaltada, atua como um espelho (AVDELIDIS; MOROPOULOU, 2002). 
As medições termográficas em materiais de contrução são influenciadas por emissividade, condições ambientais, cor e refletividade, mas apesar de o valor criterioso de emissividade contribuir de forma decisiva para medições em que a precisão dos valores de temperatura registrados pela câmera térmica representa um fator crítico na interpretação dos termogramas e análise quantitativa dos resultados, para as aplicações cujas análises qualitativas são suficientes, como diferenças de temperatura superficial, o valor de emissividade não é muito importante, não representando uma limitação para uso da tecnologia em áreas externas de edifícios, mesmo com todas as variáveis existentes (HART, 1991).

Já as variações nas condições ambientais (temperatura e umidade relativa) induzem a mudanças nas imagens térmicas, pois podem interferir com a deteç̧ão de infravermelho e porque a evaporação superficial é suscetível à sua influência, já que ela induz ao resfriamento da superfície local durante o processo de umedecimento e secagem de materiais de construção e gera diferenças de temperatura proporcionando um meio de reconhecer áreas "molhadas" e "secas", no entanto, a termografia detecta umidade apenas superficial (BARREIRA, 2004; BARREIRA; FREITAS, 2005).

Nesse processo, é necessário que a temperatura varie de, pelo menos, $1^{\circ} \mathrm{C}$ a partir da temperatura ambiente para ser detectada, por isso, essa tecnologia não pode ser utilizada para estudar objetos em equilíbrio térmico ou em domínio higroscópico (BARREIRA, 2004; HART, 1991).

A maioria dos materiais de construção comuns (gesso, pedra, cimento etc.) têm altos valores de emissividade (geralmente maior que 0,8 ) e, apesar de a norma ASTM E1933-97 fornecer um guia de medidas para determinar a emissividade de uma variedade de materiais, utilizando sistemas de imagem de infravermelhos, o uso de um material emissor de referência com um valor de emissividade conhecido deve ser utilizado para atingir os valores de emissividade do material investigado (AVDELIDIS; MOROPOULOU, 2002).

\subsubsection{Refletância e Cor}

Refletividade e cor podem mascarar defeitos e causar erros de interpretação em materiais ou componentes de construção, devendo ser considerados durante o teste 
termográfico. Refletividade é especialmente importante para materiais com baixa emissividade, uma vez que é complemento da emissividade em materiais opacos. Como tal, um objeto com baixa emissividade induz uma maior variação de temperatura superficial devido à reflexão térmica (HART, 1991). Li Z., et al. (2000) mencionou em seu trabalho o problema de refletância na inspeção termográfica de revestimentos cerâmicos e sugeriu um método para identificar reflexões solares irrelevantes.

Cores influênciam significativamente as medições termográficas causando diferenças de temperatura dependendo da tonalidade. Quanto mais intensa a cor maior a temperatura (BARREIRA; FREITAS, 2004).

\subsubsection{Transferência de Calor}

Sempre que existir uma diferença de temperatura em um meio ou entre meios diferentes, ocorre necessariamente transferência de calor por meio de mecanismos chamados radiação, condução e convecção, conforme ilustrado na Figura 10 (VALÉRIO, 2007).

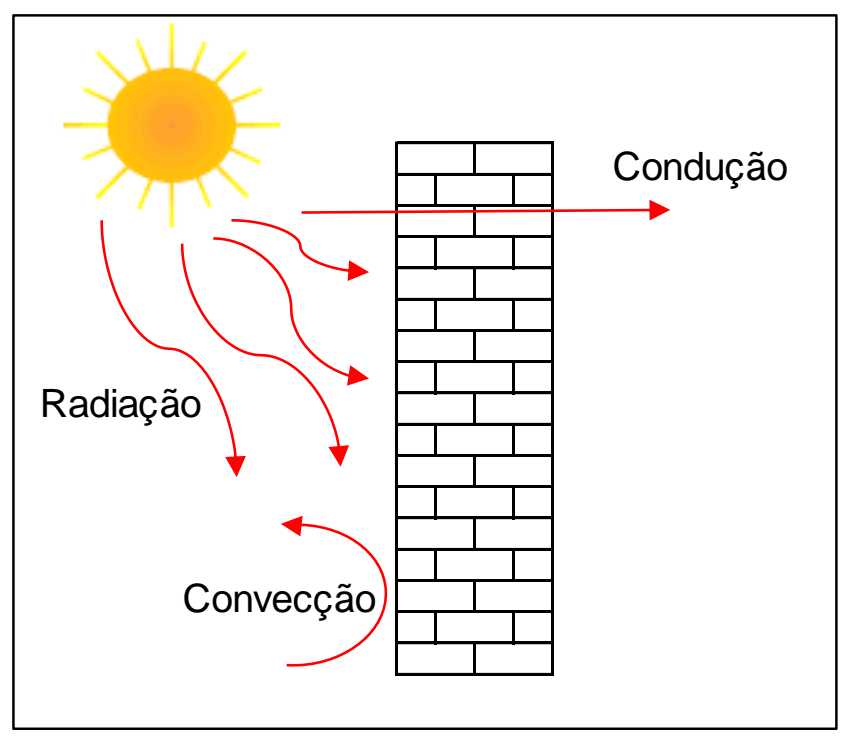

Figura 10. Mecanismo de transmissão de calor em fachadas (Adaptado de VALÉRIO, 2007, p. 7).

A transmissão do calor pela condução é a transferência de energia cinética das moléculas em sólidos, líquidos e gases. Nos sólidos e líquidos não condutores a transmissão térmica ocorre devido às oscilações longitudinais das estruturas moleculares (vibrações) e nos gases devido à colisão elástica entre as moléculas. Processo dependente da condutibilidade dos materiais e das espessuras dos 
elementos que o compõem (VALÉRIO, 2007). A lei da condução térmica, também conhecida como lei de Fourier, conforme ilustrado na equação 3 , estabelece que 0 fluxo de calor através de um material, quantidade de energia que flui através de uma unidade de área por unidade de tempo, é proporcional ao gradiente negativo de temperatura.

$$
Q=\frac{\lambda}{d}-A\left(T_{2}-T_{1}\right)
$$

Onde:

- Q é o calor transferido;

- $T_{2}$ é a temperatura da superfície quente;

- $T_{1}$ é a temperatura da superfície fria;

- A é a área através da qual o calor flui;

- $\lambda$ é a condutividade térmica, geralmente um parâmetro do material dependente da temperatura, e

- D é a espessura do corpo, medido de parede a parede.

Na convecção, a transmissão do calor é resultante da não uniformidade do número de choques por unidade de volume, durante o movimento aleatório dos fluidos (líquidos ou gasosos), e depende da velocidade e do regime de escoamento. Na radiação não há necessidade de suporte físico para ocorrer a transmissão de calor, já que se trata de um fenômeno eletromagnético de natureza ondulatória onde basta haver diferença de temperatura entre as superfícies independente do meio que as separa (LABRINCHA, 2006).

$\mathrm{Na}$ identificação de defeitos em uma edificação composta naturalmente por diferentes tipos de materiais e diferentes geometrias das superfícies podem ocorrer os três mecanismos de transmissão em diferentes direções, são as chamadas pontes térmicas: condução entre os elementos que compõem o revestimento de fachada, convecção através da troca de energia com o ar na fachada e radiação emitida pela fonte de energia como o sol. (INCROPERA, 2003; CORVACHO, 1998).

Segundo Valério (2007), as pontes térmicas:

- seguem a trajetória com menor resistência térmica. 
- podem ser originadas por intermédio da transição entre materiais com diferentes condutividades térmicas, de alterações na espessura de um elemento e diferenças entre áreas internas e externas.

- apresentam maiores taxas de perda de calor, causando temperaturas superficiais mais baixas nos locais de sua ocorrência e diferenças na distribuição das temperaturas no interior dos elementos.

\subsubsection{Reflexão, Transmissão e Absorção}

Os corpos reais, de maneira geral, não são corpos negros. A radiação incidente sobre um corpo real é parte refletida, parte transmitida e parte absorvida (Figura 11) em proporções que vão depender da temperatura do objeto, das características de emissividade e de refletância da superfície e da composição do material, contudo, baseado no princípio da conservação de energia, a soma dessas partes é igual à energia incidente total (BERTIL; BENGT, 1980).

A refletividade $(\rho)$ é uma propriedade que determina a fração da radiação incidente que é refletida pela superfície (devolução da radiação recebida); a absortividade ( $\alpha$ ) é uma propriedade que determina a fração da radiação captada que é absorvida pela superfície e a transmissividade $(\tau)$ é a propriedade que determina a fração da radiação que é transmitida através da superfície.

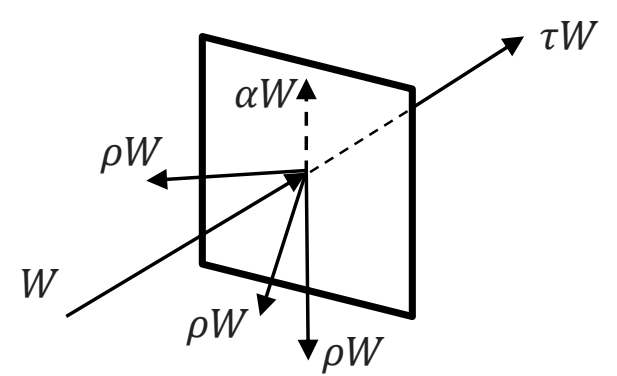

$$
\begin{aligned}
& \rho=\text { refletância } \\
& \alpha=\text { absortância } \\
& \tau=\text { transmitância } \\
& W=\text { radiação incidente }
\end{aligned}
$$

Figura 11. Ilustração de radiação incidênte $(W)$, radiação refletida $(\rho W)$, radiação absorvida $(\alpha W)$ e radiação transmitida $(\tau W)$ (Fonte: Measurement in thermography).

Esses parâmetros dependem do comprimento de onda e para um mesmo comprimento de onda a soma das três propriedades é igual a um, conforme ilustrado na equação 4 (HAGENTOFT, 2001).

$$
\alpha(\lambda)+\sigma(\lambda)+\tau(\lambda)=1
$$


onde $\alpha(\lambda)$ é a absorção espectral para um determinado comprimento de onda, $\rho(\lambda)$ é o espectro de reflexão para um determinado comprimento de onda e $\tau(\lambda)$ é a transmissão espectral para um determinado comprimento de onda. De acordo com a Lei de Kirchhoff, em equilíbrio térmico, a emissividade de uma superfície é igual à absortividade, conforme a equação 5 (INCROPERA; WITT, 2001).

$$
\alpha(\lambda)=\varepsilon(\lambda)
$$

eq. 5

Considerando-se a Lei de Kirchhoff, a equação pode ser escrita como (equação 6):

$$
\varepsilon(\lambda)+\rho(\lambda)+\tau(\lambda)=1
$$

eq. 6

\subsubsection{Câmera Térmica}

Não há câmera infravermelha que consiga ler a temperatura diretamente. Elas transformam a radiação infravermelha (emitida, refletida e transmitida) proveniente da superfície investigada e invisível ao olho humano, modificando a frequência para faixa visível do espectro eletromagnético. (AVDELIDIS; MOROPOULOU, 2002).

Para isso, a câmera térmica é equipada com uma série de lentes mutáveis, onde o núcleo da câmera é o detector infravermelho que capta a radiação emitida pelo objeto, converte em tensão elétrica ou corrente e cria uma imagem térmica, mostrando a distribuição de temperatura superficial do corpo. Cada tonalidade expressa um intervalo específico de temperatura (BARREIRA; FREITAS, 2005).

Um termovisor profissional de alto desempenho possui mais de 300 mil sensores de temperatura independentes, conhecidos como pixels que captam apenas energia radiante recebida da superfície do objeto, e não sua luz visível refletida, o que significa que as imagens térmicas podem ser obtidas mesmo em total escuridão (RAO, 2008).

A distância entre o termovisor e o objeto altera de acordo com a combinação termovisor vs lente. Um mesmo termovisor poderá possuir diferentes campos de visão (FOV - Figura 12-a) se utilizado com mais de um tipo de lente. Consequentemente, o campo de visão instantâneo (IFOV - Figura 12-b) que é a dimensão projetada do pixel na cena irá também variar seu tamanho. Um termovisor com lente de $24^{\circ}$ a um metro 
de distância do alvo poderia identificar um objeto de no máximo 0,65 mm de diâmetro, ao ponto que se substituirmos a lente de $24^{\circ}$ por uma lente de $12^{\circ}$, esse mesmo termovisor poderia identificar um objeto de $0,33 \mathrm{~mm}$ de diâmetro na mesma distância (Manual Técnico FLIR, 2009).

Não há distância máxima, o que limita a distância é o tamanho do alvo, assim, a área sensoriada (alvo) deve preencher o campo de visão (Figura 13). Quanto maior a distância do termovisor em relação ao alvo (aumento do campo de visão), maior será a área coberta por um pixel, perdendo definição. Para melhorar a assertividade da medição e melhorar a resolução é necessário aumentar a densidade de pixel por detector (Figura 14) ou reduzir a distância em relação ao alvo.
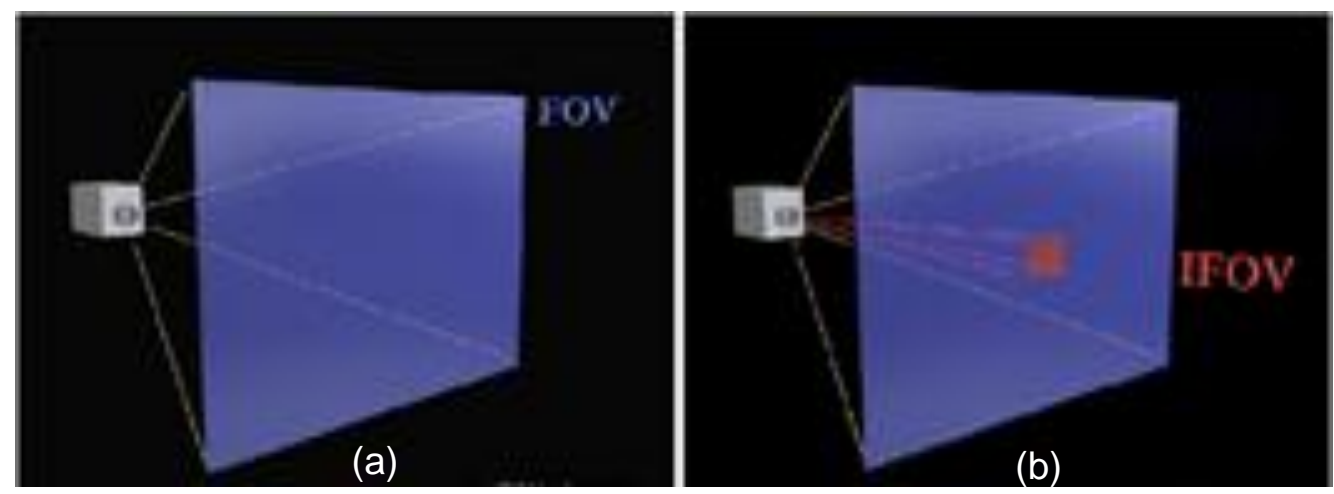

Figura 12. (a) Campo de visão - FOV; (b) Campo de visão instantâneo - IFOV (Fonte: Manual do usuário FLIR).

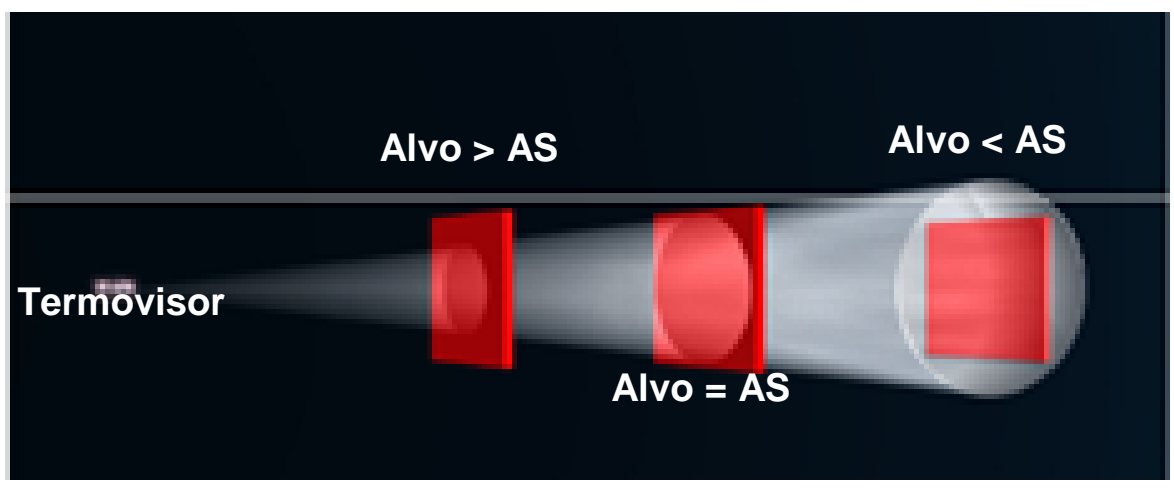

Figura 13. Relação Alvo x Área Sensoriada (AS). (Fonte: Manual do usuário FLIR). 


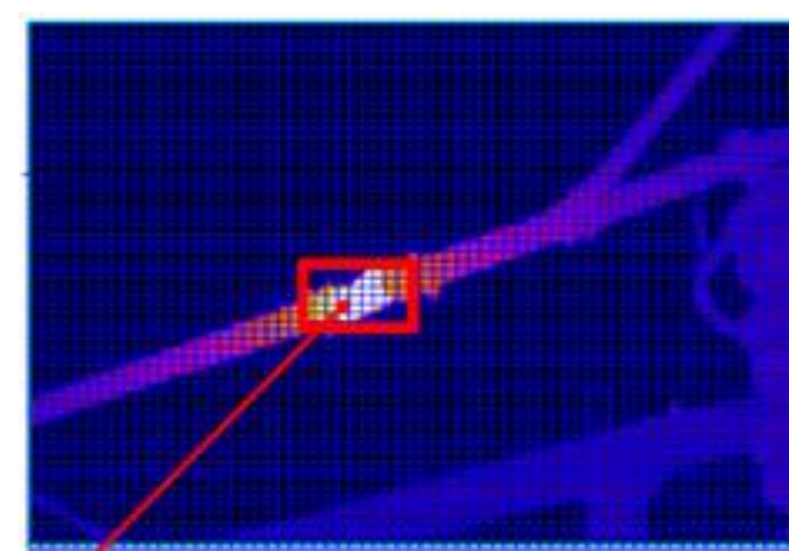

Figura 14. Quantidade de pixel cobrindo o objeto (Fonte: Manual do usuário FLIR).

\subsubsection{Imagem Infravermelha}

Saber interpretar uma imagem térmica é fundamental para se tirar conclusões assertivas. Dentre as características da imagem térmica, a cor é utilizada para análises qualitativas e sua variação é determinada pela temperatura de cada pixel, podendo ser interpretada equivocadamente caso os critérios corretos não sejam utilizados. Pelos recursos atualmente disponíveis nos equipamentos, é possível obter imagens que variam cores e tons através de diferentes paletas de cores, mas cuja cena, escala e temperaturas são idênticas (Manual Técnico FLIR, 2009).

Na prática, pode-se utilizar, grosso modo, as seguintes definições (Manual Técnico FLIR, 2009).

- pequenas variações de temperatura são mais facilmente identificadas quanto maior a quantidade de cores, dessa forma, para cenas com baixo contraste térmico, deve-se usar um alto contraste de cores;

- caso pequenas variações de temperatura não sejam relevantes, potenciais defeitos são mais facilmente identificados com menos cores, assim, para cenas com alto contraste térmico recomenda-se usar um baixo contraste de cores.

Somado a esses critérios, está o foco térmico ou ajuste térmico da imagem, por meio do qual se estabelece a amplitude (temperaturas máximas e mínimas da cena) e nível (ponto intermediário da amplitude), ambos características da imagem, utilizando os recursos da câmera térmica ou o software de análise com o objetivo de salientar o que se deseja investigar. Esse recurso é possível, pois, para cada pixel da imagem que possui uma cor há também uma temperatura associada. Uma imagem sem foco 
diminui a temperatura lida em um corpo quente podendo levar a erros de interpretação (Manual Técnico FLIR, 2009).

As medições podem ser qualitativas ou quantitativas. A qualitativa compara a assinatura térmica de um componente com outro igual ou similar sob as mesmas condições de operação. O defeito é identificado pela variação de intensidade entre dois objetos similares sem valores de temperatura. Essa técnica é facil e usualmente não requer nenhum ajuste do sistema de imagem térmica para compensar as condições atmosféricas ou emissividade da superfície. Medidas qualitativas são usadas para inspeções de obra (HOLST, 2000). A medição quantitativa é usada para classificar a seriedade de uma anomalia e envolve medição de temperatura.

\subsubsection{Fatores que influenciam medições termográficas em edificações}

Apesar de qualquer objeto emitir energia proporcional à sua temperatura superficial, a energia realmente detectada depende da emissividade da superfície sob medição, da distância do objeto, da temperatura e do ambiente (BARREIRA et al., 2014).

De fato, uma fração da radiação pode ser absorvida pela atmosfera entre o objeto e a câmera ou adicionada como energia refletida pela superfície do entorno podendo levar a erros na análise e interpretação de dados. Para que essa composição possa ser determinada corretamente é preciso fornecer parâmetros precisos ao instrumento para a compensação dessas variáveis e cálculo da temperatura do objeto com uma aproximação aceitável da temperatura real. O ajuste de emissividade em um equipamento infravermelho compensa a energia não emitida pelo corpo (AVDELIDIS; MOROPOULOU, 2002; MINKINA; DUDZIK, 2009; EDIS, 2013).

Outros fatores que influenciam na medição da temperatura através da câmera termográfica, dentre eles estão: o vento, se possuir uma velocidade considerável pode afetar no resultado das imagens térmicas; uma fonte de calor externa, por exemplo, o sol, que pode alterar o fluxo normal de calor do interior para o exterior da fachada em estudo (BARREIRA, 2004).

\subsubsection{Termografia aplicada à identificação de defeitos em edificações}

Estudos voltados ao desenvolvimento de aplicações da técnica de termografia para controle preventivo e corretivo em obra viabilizando a identificação e mapeamento de 
defeitos ocultos nos revestimentos de fachadas simplificam e tornam a recuperação de defeitos mais rápida e econômica, contribuindo com a redução/eliminação de intervenções pós obra causados por falhas durante a execução.

Em análises termográficas de edificações procuram-se identificar a existência de incoerências nos padrões de temperatura dos elementos construtivos, quando analisados nas mesmas condições. A ocorrência de diferenças de temperatura pode indicar a existência de problemas. Na aplicação da tecnologia para identificar defeitos, quanto menores as variações de temperatura capturadas pelo equipamento de termografia em temperatura ambiente (que corresponde a aproximadamente $300 \mathrm{~K})$ maior a capacidade de identificar defeitos, independente do uso de fontes de calor naturais (sol) ou artificiais (luzes) ou de resfriamentos forçados necessários para gerar variações de temperaturas que ressaltem tais defeitos nas imagens térmicas. No entanto, esse aumento da sensibilidade do equipamento requer uma acuracidade maior na interpretação da imagem para evitar diagnósticos equivocados (Manual Técnico FLIR, 2009).

A lei de deslocamento de Wien cria uma relação simples entre o comprimento de onda de pico e a temperatura (equação 7).

$$
\lambda_{\text {pico }}=\frac{2898}{T}[\mu m]
$$

Onde $\lambda(\mu \mathrm{m})$ é o comprimento de onda e $T$ é a temperatura $(\mathrm{k})$. Nesse caso, para a temperatura de 300K a Lei de Wien indica que o pico de energia encontra-se na região de comprimento de onda de $10 \mu \mathrm{m}$, ou seja, para essa aplicação, o mais indicado é utilizar um equipamento de onda longa (LW - long wave) que possibilita medir a menor porção de energia emitida pelo ambiente. (Manual Técnico FLIR, 2009).

Na maioria dos estudos de investigação sobre a detecção de problemas de umidade por TRI, o resfriamento evaporativo é usado como uma força motriz em materiais porosos/permeáveis. No caso de fachadas com cerâmica, a resina da cerâmica impede a evaporação e, portanto, o arrefecimento por evaporação não pode atuar 
como uma força motriz. Assim, o aumento da capacidade de armazenamento de calor do material úmido pode então ser usado como uma força motriz (EDIS, E. et al., 2014).

In situ, as microfissuras também são difíceis de detectar e são altamente dependentes das condições meteorológicas não sendo possível detectá-las em dias com nebulosidade devido ao baixo efeito de aquecimento da radiação solar. Embora as microfissuras com retenção de umidade na maioria das vezes possam ser identificadas a olho nu durante o processo de secagem, o potencial de visualização através da termografia aumenta devido ao efeito de variação de temperatura entre a fissura e a superfície próxima em razão do resfriamento evaporativo ou pelo aumento da capacidade de armazenamento de calor gerado pela água presente no interior da fissura. Atualmente, devido ao grande desenvolvimento das câmeras térmicas disponíveis no mercado, é possível obter imagens com alto nível de detalhe dos defeitos de fissuras a curta distância (ROSINA; LUDWIG, 1999; BARREIRA, et al. 2014).

\subsubsection{Tipos de Termografia}

Geralmente o uso da termografia para avaliação não destrutiva ocorre por duas técnicas:

- Pulso termografia (PT):

$\mathrm{Na}$ maior parte das vezes realizada estimulando o objeto através de um pulso de aquecimento (Figura 15-a) e monitoramento da evolução da temperatura de sua superfície durante a fase de aquecimento transitório ou de arrefecimento. Análises com a PT podem ser realizadas de dois modos diferentes: transmissão e reflexão. No modo de transmissão, a câmera infravermelha vê a face posterior (traseira), ou seja, oposta à fonte de aquecimento/arrefecimento. No entanto, nas aplicações reais, o lado oposto é geralmente não acessível e, portanto, o modo de reflexão deverá ser aplicado tanto com a câmera infravermelha e o estímulo à fonte do mesmo lado (MEOLA, C. et al., 2003).

A energia térmica propaga abaixo da superfície por condução (Figura 15-b) enquanto a câmera infravermelha monitora as variações de temperatura da superfície. Obviamente, a distribuição de temperatura é uniforme no caso de um aquecimento 
uniforme e material homogêneo, assim, a presença de um defeito numa determinada camada interfere com a propagação da energia térmica e provoca uma diferença de temperatura localizada (Figura 15-c).

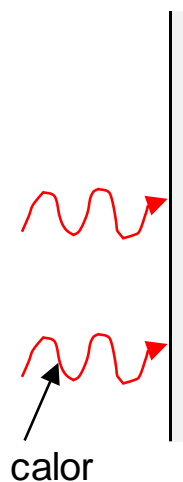

calor

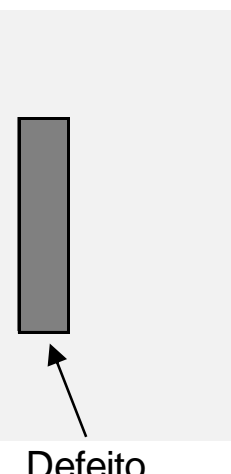

(a)

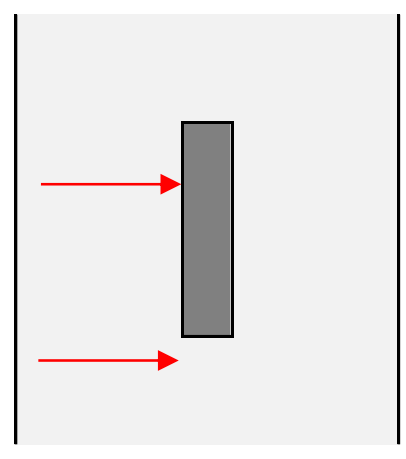

(b)

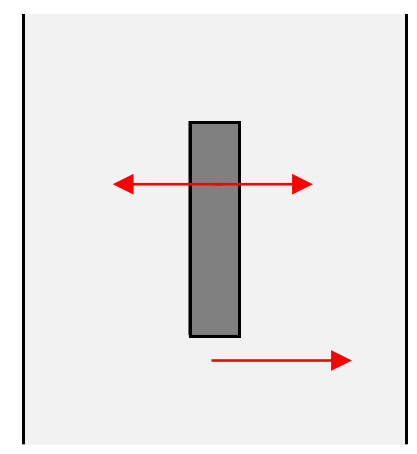

(c)

Figura 15. Propagação de um pulso de calor em um material: (a) Um impulso de energia é aplicado à superfície; (b) O pulso de calor viaja dentro do material e encontra um defeito; (c) O defeito reflete parcialmente e transmite parcialmente o pulso (Adaptado de HOLST, 2000).

Geralmente, um defeito profundo se torna visível depois que a primeira camada interna e um grande defeito produz uma diferença de temperatura maior do que a área sem defeito. A evolução do fenômeno pode ser observado por intermédio do registro de uma sequência de imagens, que, após tratadas com o uso de softwares específicos, dão informações sobre defeitos. É importante resaltar que os resultados podem ser afetados pelo aquecimento não uniforme e emissividade (MEOLA, C. et al., 2003; VAVILOV, 1992).

- Termografia em bloqueio (LT):

A técnica de bloqueio utiliza ondas térmicas. O processo consiste em acoplar o equipamento que utiliza o sistema de bloqueio a uma fonte térmica de onda que é operada de tal maneira que resulta em uma modulação de temperatura sinusoidais; a modulação é gerada por um sinal elétrico não linear produzido pelo módulo de bloqueio em que tem uma tabela de forma de onda para esta finalidade. A fonte de calor tem de ser calibrada (para cada frequência) para assegurar que a temperatura da onda formada seja realmente sinusoidal (MEOLA, C. et al., 2002). 
A transferência periódica de calor na superfície (profundidade $z=0$ ) de um material semi-infinito homogêneo resulta em uma (dependente do tempo) onda térmica, que em uma dimensão, é dada pela equação 8:

$$
T(z, t)=T_{0} \exp \left(-\frac{z}{\mu}\right) \exp i\left(w t-\frac{z}{\mu}\right)=A(z) \exp i[\omega t-\emptyset(z)]
$$

onde $A(z)$ é a amplitude térmica, $\varnothing(z)$ é o desvio de fase da onda térmica que passa no interior do material, $\mu$ é o comprimento de difusão térmica, que é calculado a partir da difusividade térmica $\alpha$ é uma frequência de onda $f=\omega / 2 \pi$ (equação 9).

$$
\mu=\sqrt{\frac{\alpha}{\pi f}}
$$

$\mathrm{Na}$ análise do bloqueio, o sistema recolhe uma série de imagens e compara as suas temperaturas computando amplitude e ângulo de fase da onda sinusoidal padrão em cada ponto e que a imagem resultante pode ser uma imagem de amplitude ou uma imagem de fase. O intervalo de profundidade, para a amplitude da imagem, é dado por $\mu$, enquanto a profundidade máxima, $\rho$, que pode ser inspecionada, para a imagem de fase corresponde a 1,8 $\mu$. A técnica de LT é insensível ao aquecimento não uniforme e à variação de emissividade local; é particularmente atraente para a investigação de mosaicos, afrescos e pinturas. 


\section{METODOLOGIA}

\subsection{Escaneamento 3D laser aplicado à planicidade e volumetria de argamassa em fachada}

A viabilidade do uso do escaneamento 3D laser em obras passa por diferentes fatores intervenientes que vão desde a escolha do escâner, passando pelas características do canteiro e do projeto. Para se alcançar o objetivo do trabalho foi desenvolvido um estudo de caso em um prédio em construção, no qual a partir do modelo escaneado de uma das fachadas foram realizadas uma série de análises e interpretações.

\subsubsection{Escolha do equipamento}

O tempo para uma varredura completa foi apontado em alguns estudos anteriores como uma limitação do escaneamento 3D, dessa forma, o primeiro ponto para viabilizar o uso dessa tecnologia em fachada de edifícios foi identificar um equipamento com capacidade de escanear rapidamente a superfície em questão, com portabilidade suficiente para ser facilmente transportado e montado, favorecendo seu deslocamento e uso no canteiro de obras.

O escâner escolhido foi o SURPHASER 25HSX (Figura 16-a) que utiliza a tecnologia de varredura hemisférica a laser de alta precisão do tipo phase-shift. O laser é escaneado em torno da cena que está sendo digitalizada, em três dimensões, reunindo medições de distância em intervalos de ângulo especificados (Figura 16-b). O equipamento apresenta uma precisão de $0,1 \mathrm{~mm}$ a 0,2 $\mathrm{mm}$, raio máximo de leitura de 25 metros, ângulo máximo de 85 graus e velocidade de captura que varia de 300.000 a 1.200 .000 pontos por segundo, permitindo a varredura de uma fachada em poucos minutos. O nível de ruído (imprecisão) abaixo de 0,2 $\mathrm{mm}$ associados à densidade de pontos permite capturar detalhes precisos da superfície escaneada.

Para manutenção da estabilidade, o equipamento fica acoplado a um tripé e os dados coletados durante a varredura são armazenados em um notebook conectado ao equipamento por meio de um cabo USB ou via wireless. 


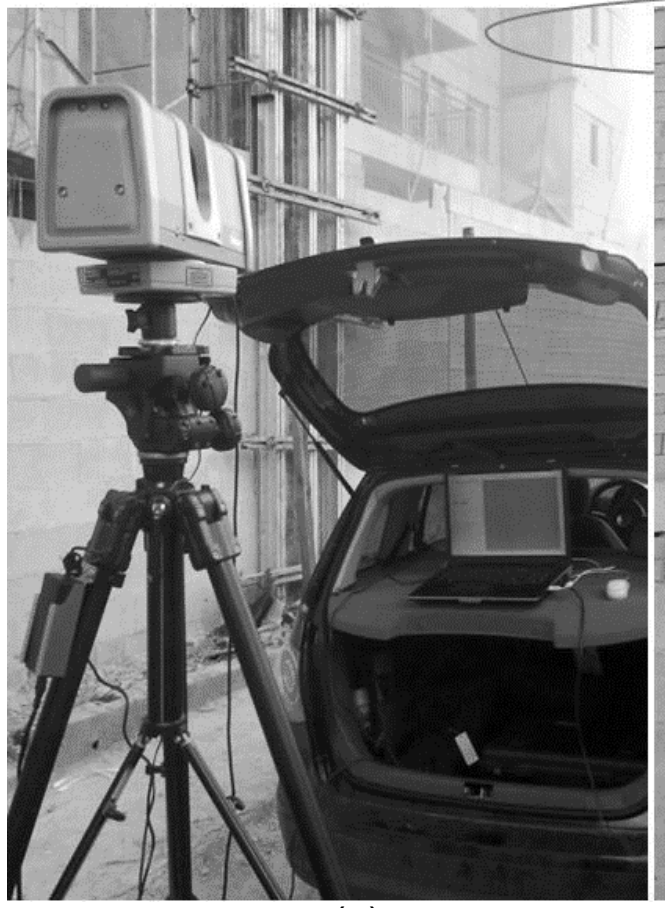

(a)

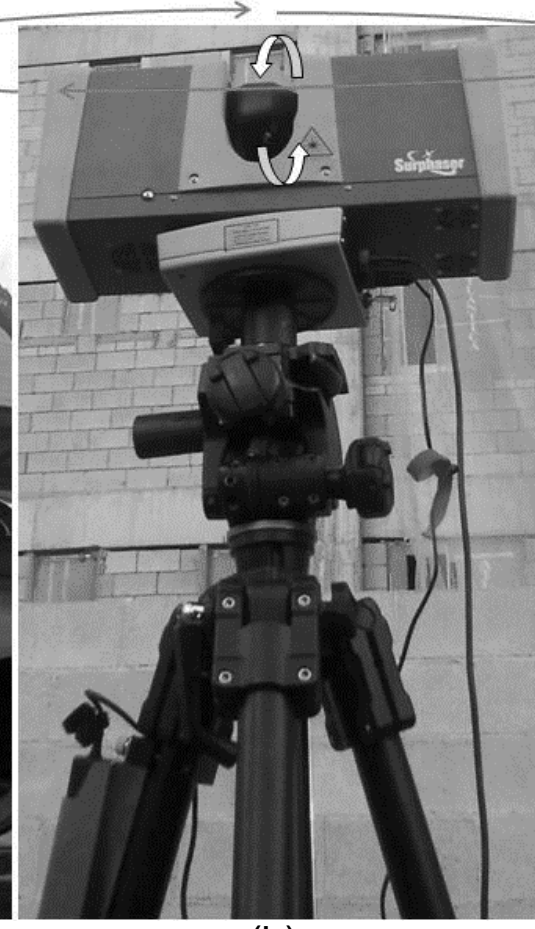

(b)

Figura 16. Escâner SURPHASER 25HSX (Fonte: T1 Engenharia).

Conforme ilustrado na Figura 17, para produzir um modelo 3D, esse tipo de escâner gira horizontalmente a $360^{\circ}$, enquanto a cápsula onde se encontra o espelho rotativo, posicionada na parte central do cabeçote, emite o laser infravermelho na medida em que gira $360^{\circ}$ na vertical para medir a distância do objeto no seu caminho, viabilizando, assim, o escaneamento hemisférico e campo de visão de $360^{\circ} \times 270^{\circ}$.

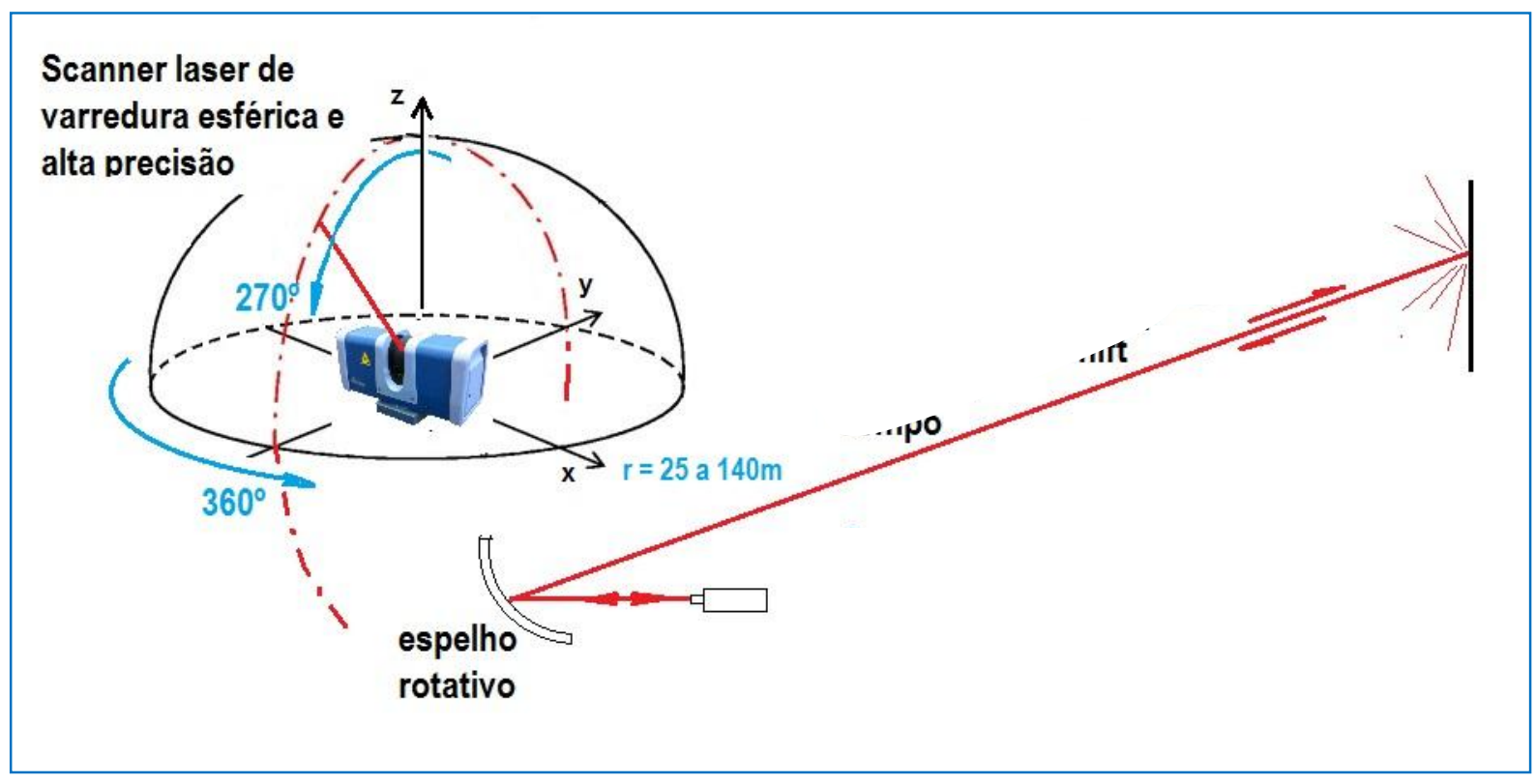

Figura 17. Esquema de varredura 360 (Fonte: T1 Engenharia Digital). 


\subsubsection{Escolha da obra}

Do conjunto de obras disponibilizadas, o estudo foi realizado naquela que melhor se ajustava às condições de contorno e aos requisitos estabelecidos como necessários na etapa de planejamento para uma leitura plena da superfície do substrato.

- características da obra:

$>$ obra em estrutura de concreto armado cujos alinhamentos e nivelamentos das fôrmas de concretagem fossem realizadas pela técnica do fio de arame.

> alvenaria de vedação em bloco de concreto alinhada e nivelada pela mesma técnica.

$>$ área de fachada sem zonas de sombreamento (ocultações).

- fase da obra: estrutura de concreto e alvenaria de vedação concluída, execução de chapisco e regularização em argamassa não iniciada.

A obra escolhida foi um edifício de 24 pavimentos, porém, como o afastamento máximo possível entre o escâner e a fachada foi de $10 \mathrm{~m}$, aproximadamente, e parte da fachada apresentava tela (Figura 18-a), apenas sete pavimentos de uma fachada frontal foram escaneados, ou seja, a área analisada representou $14,3 \%$ dessa fachada, conforme ilustrado na Figura 18-b.

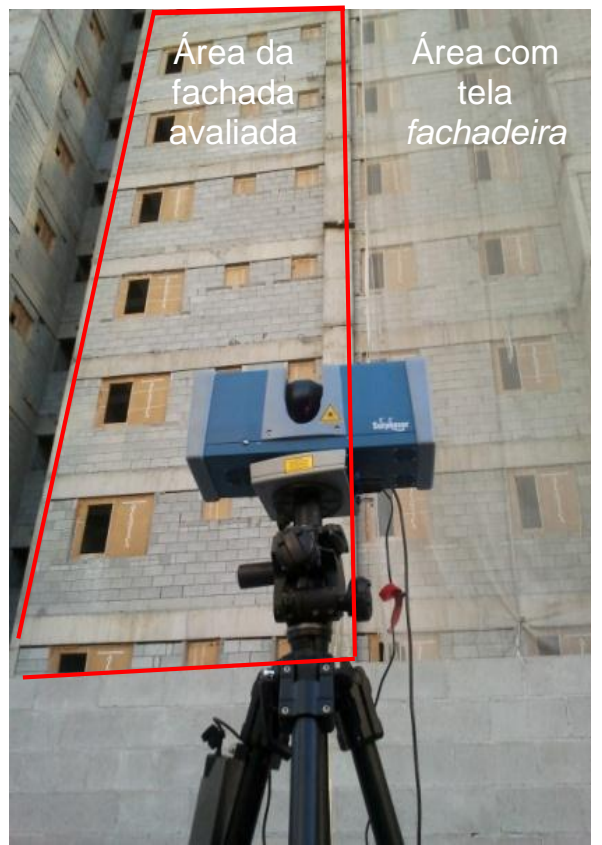

(a)

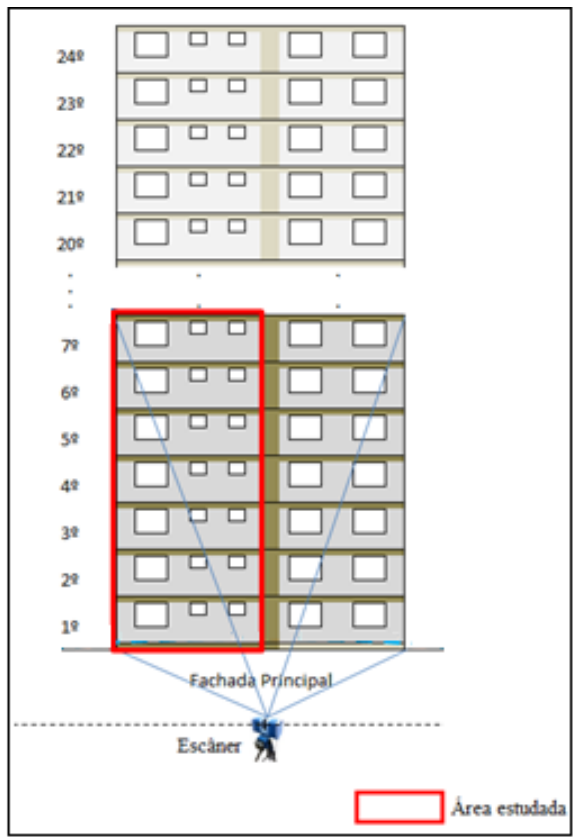

(b)

Figura 18. (a) Imagem da obra com detalhe da fachada avaliada e da tela fachadeira; (b) Esquemático da localização do escâner em relação ao prédio. (Fonte: Elaborado pelo autor). 


\subsubsection{Uso do software Geomagic}

Para analisar a planicidade da fachada e quantificar volumetricamente a argamassa com uso do software Geomagic, após o escaneamento da fachada, foram cumpridos os seguintes passos:

- Planicidade da fachada:

> posicionar o modelo 3D completo em relação ao projeto original;

> calcular o plano de referência da fachada passando pelo eixo das vigas a partir do ponto médio de suas superfícies;

> gerar o mapa de cores mostrando visualmente todas as depressões e protuberâncias do substrato no software, a partir do plano médio;

> visualizar as áreas com maiores graus de impacto sobre a planicidade da fachada (estrutura e alvenaria) e identificar os locais com as maiores e menores espessuras de argamassa;

> calcular planos, simulando diferentes espessuras de argamassa de revestimento, mostrando por meio de escala de cores as variações de espessura por meio do cálculo da distância de cada ponto dos planos até a superfície da fachada escaneada;

> comparar a maior espessura e espessura média do revestimento de argamassa em cada plano com a espessura de $25 \mathrm{~mm}$ (média da espessura entre o intervalo de $20 \mathrm{~mm}$ a $30 \mathrm{~mm}$ indicado pela NBR13749 (ABNT, 2013);

$>$ identificar os planos com maior e menor percentual de área com espessura mínima de 25 mm e locais de concentração dessas áreas.

- Volumetria de argamassa:

posicionar o modelo 3D completo em relação ao projeto original;

calcular o plano de referência da fachada passando pelo ponto mais externo da fachada, mostrando a distribuição de espessuras nas regiões da fachada atrás do plano por meio de uma escala de cores; 
> gerar o mapa de cores mostrando visualmente o percentual total de área com espessura mínima de $25 \mathrm{~mm}$;

- calcular planos simulando diferentes espessuras de argamassa de reboco até o limite de $25 \mathrm{~mm}$ sobre o ponto mais externo da fachada (100\% da fachada com espessura mínima de $25 \mathrm{~mm}$ ), mostrando por meio de escala de cores as variações de espessura através do cálculo da distância de cada ponto dos planos até a superfície da fachada escaneada;

> comparar o consumo de argamassa em cada plano vs o percentual total de área com espessura mínima de $25 \mathrm{~mm}$;

> identificar a economia no consumo de argamassa a partir da redução percentual do volume em comparação com o plano onde $100 \%$ da fachada, independente das irregularidades, apresenta espessura mínima de $25 \mathrm{~mm}$;

analisar a viabilidade econômica do uso da técnica de escaneamento 3D neste estudo de caso.

\subsubsection{Experimento realizado e definição de planos de referência}

Para a realização da varredura, o escâner foi posicionado de frente para a fachada (Figura 19-a). A partir do modelo escaneado e com recursos do software Geomagic, desenvolvido pelo próprio fabricante do equipamento, foram criados dois planos de referência utilizados como base para os estudos de consumo de argamassa de revestimento.

Conforme ilustrado na Figura 19-b, o primeiro plano de referência P0 corta o eixo das sete vigas passando pelo ponto médio de suas superfícies. A partir dele foram traçados cinco novos planos paralelos nomeados como P1, P2, P3, P4, P5, afastados 5, 10, 15, 20 e $25 \mathrm{~mm}$ respectivamente de P0 (Figura 19-c), simulando diferentes espessuras de argamassa de revestimento. 


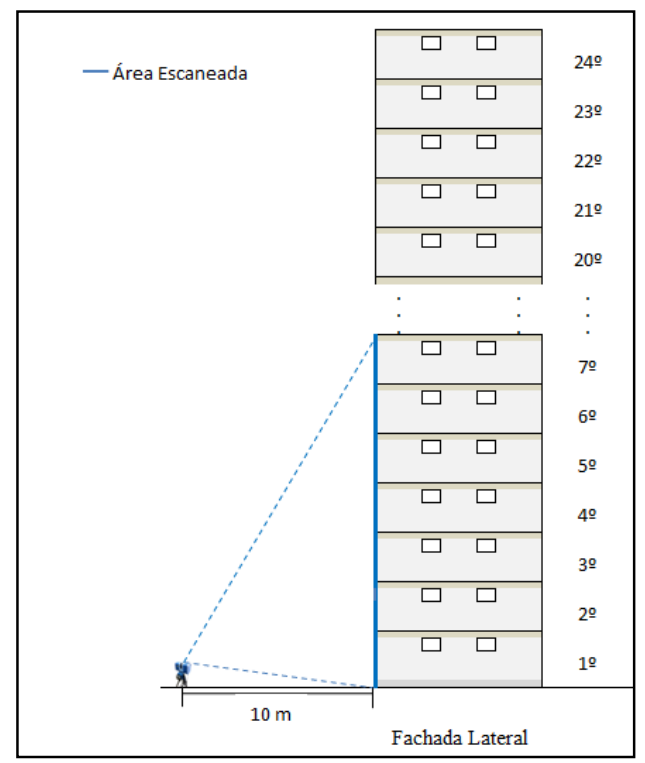

(a)

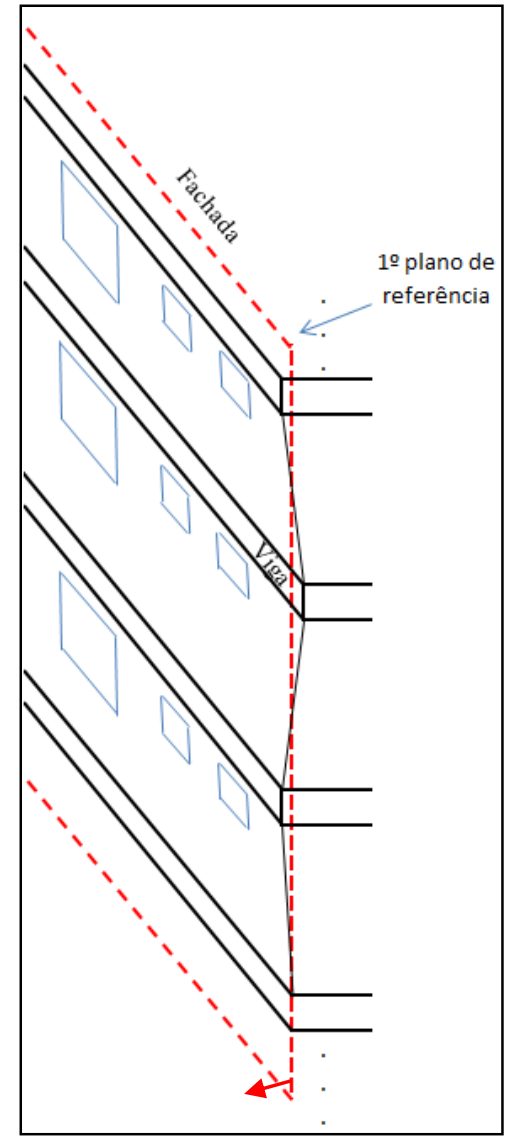

(b)

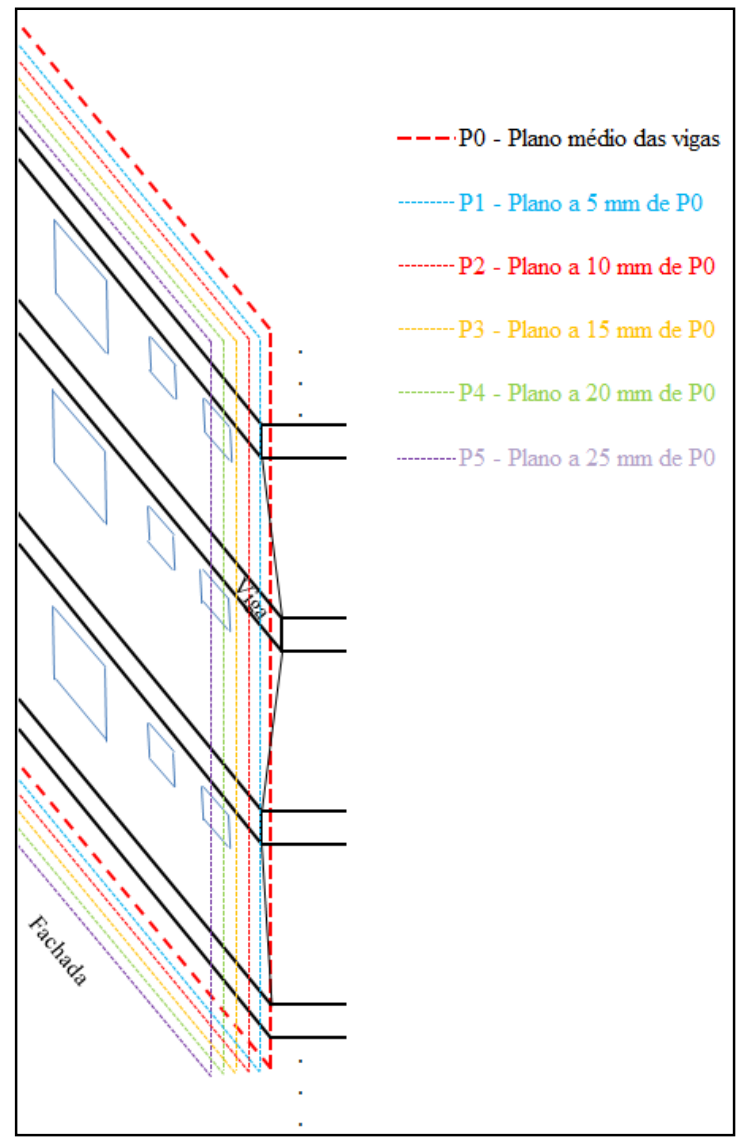

(c)

Figura 19. (a) Distância do escâner em relação à fachada; (b) $1^{\circ}$ Plano de referência; (c) Planos simulando diferentes espessuras de argamassa (5 mm - azul / $10 \mathrm{~mm}$ - vermelho / $15 \mathrm{~mm}$ amarelo / $20 \mathrm{~mm}$ - verde / $25 \mathrm{~mm}$ - cinza) e paralelos ao 1ํ plano de referência.

(Fonte: Elaborado pelo autor). 
Enquanto o primeiro plano de referência foi traçado a partir das vigas da fachada, o segundo plano de referência foi traçado a partir do ponto mais externo da fachada, conforme ilustrado na Figura 20-a. A partir dele foram criados três novos planos afastados 5, 15 e 25 milímetros respectivamente (Figura 20-b) com o objetivo de simular um revestimento de argamassa que atendesse à espessura de $25 \mathrm{~mm}$ (espessura intermediária entre o intervalo de 2 a $3 \mathrm{~cm}$ indicado pela NBR 13749 (ABNT, 1996) em $100 \%$ da área da fachada comparativamente com revestimentos que não atendessem a esta premissa $(5 \mathrm{~mm}$ e $15 \mathrm{~mm})$.

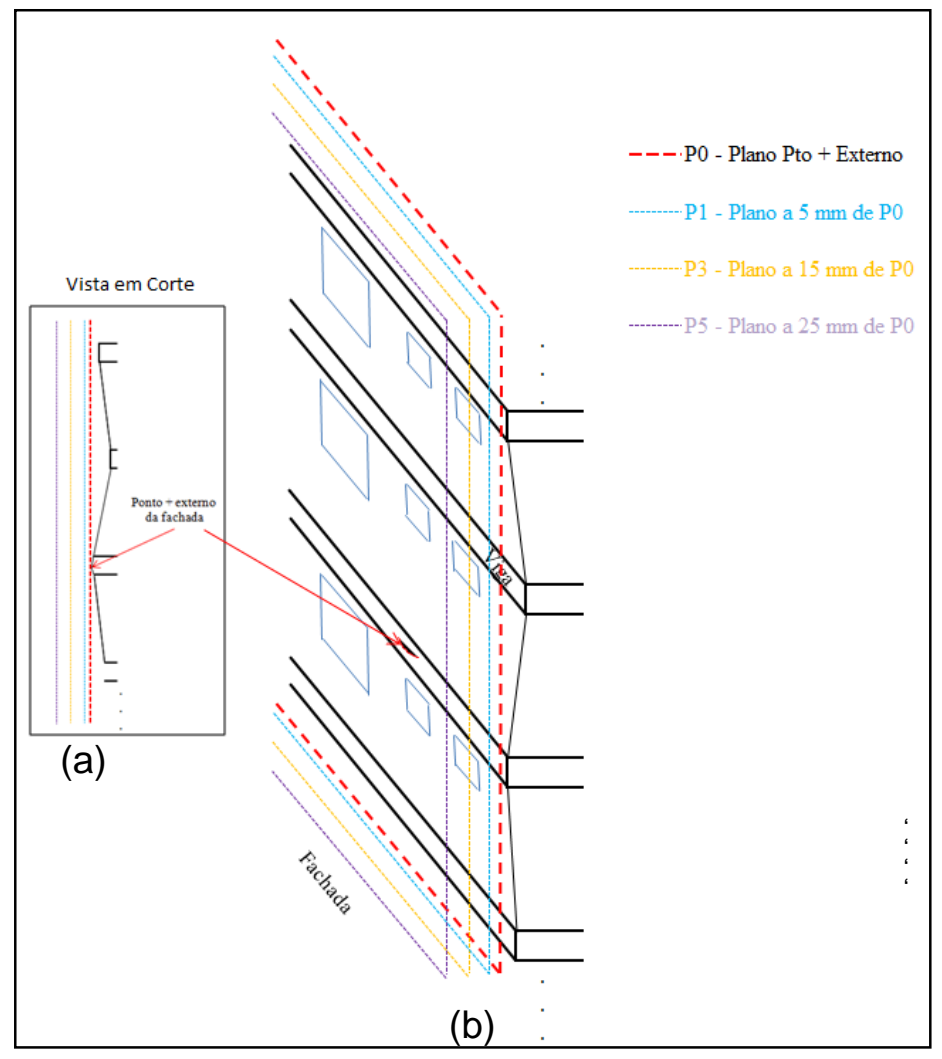

Figura 20. (a) Detalhe do ponto mais externo da fachada no Plano 0'; (b) llustração dos planos a $5 \mathrm{~mm}$ (azul), $15 \mathrm{~mm}$ (amarelo) e $25 \mathrm{~mm}$ (cinza) em relação ao plano (vermelho) traçado a partir do ponto mais externo da fachada. (Fonte: Elaborado pelo autor).

\subsection{Aplicação da termografia infravermelha na identificação de defeitos de fachada}

O método utilizado para desenvolver os objetivos propostos neste estudo foi baseado na análise de termogramas obtidos por câmeras térmicas sob abordagens passiva e ativa para gerar diferenças de temperatura na superfície de revestimentos, permitindo medições qualitativas para avaliar a existência ou não de defeitos ocultos. 
Para isso, o trabalho foi divido em três etapas experimentais: laboratório, campo e in situ, conforme já descrito no item 2.1.

\subsubsection{Escolha do equipamento}

A câmera térmica selecionada foi a T-640 do fabricante Flir (Figura 21) por atender aos requisitos de portabilidade e possuir ajustes para minimizar os impactos causados por diferentes fontes de interferência em ambientes externos (fachadas) e cujos detalhes técnicos encontram-se nas Tabela 4.

- $\mathrm{T}-650$
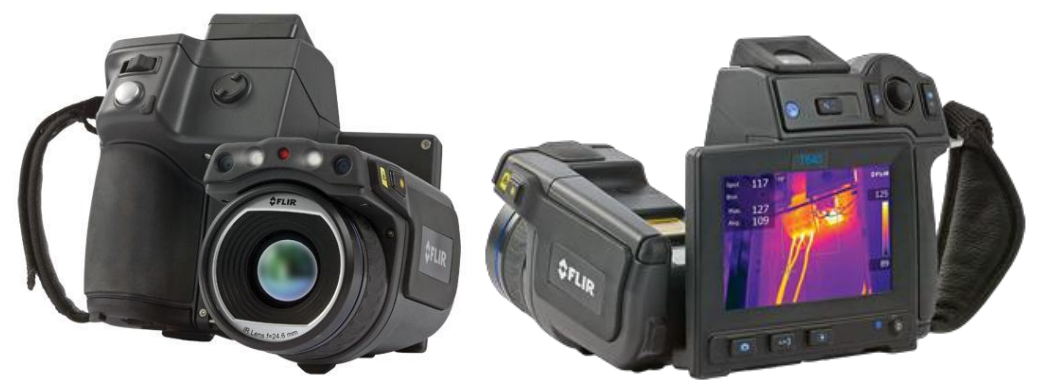

Figura 21. Detalhes da câmara térmica T-650 (Fonte: Flir).

Tabela 4. Características da Câmera Térmica T-640 (Fonte: Flir).

\begin{tabular}{|l|c|}
\hline \multicolumn{2}{|c|}{ Flir T640 } \\
\hline Precisão & $\pm 2 \%$ ou $2^{\circ} \mathrm{C}$ \\
\hline Resolução & 307.200 pixels $(640 \times 480)$ \\
\hline Sensibilidade Térmica & $<0.035^{\circ} \mathrm{C}$ \\
\hline Faixa de Temperatura & $-40^{\circ} \mathrm{C}$ até $2.000^{\circ} \mathrm{C}$ \\
\hline Campo de Visão & $25^{\circ} \times 19^{\circ}$ \\
\hline Distância Mínima para foco & $0.25 \mathrm{~m}$ \\
\hline Zoom Digital & $8 \times$ \\
\hline Peso (incluindo bateria) & $1.3 \mathrm{~kg}$ \\
\hline
\end{tabular}

Para garantir a qualidade das imagens térmicas, a estabilidade do equipamento é fundamental. Para isso, nas etapas de laboratório e de campo a câmera foi acoplada 
a um tripé e mantida a uma distância fixa das superfícies analisadas de acordo com cada uma das etapas experimentais.

Para realizar imagens com melhor resolução na etapa in situ foi utilizado o recurso do drone (Figura 22) ao qual a câmera térmica foi acoplada para aproximação às regiões com defeitos.

Com o auxílio dos recursos disponíveis no software FLIR Tools, as imagens capturadas durante os ensaios foram trabalhadas para permitir análises com o melhor grau de precisão e confiabilidade possível.

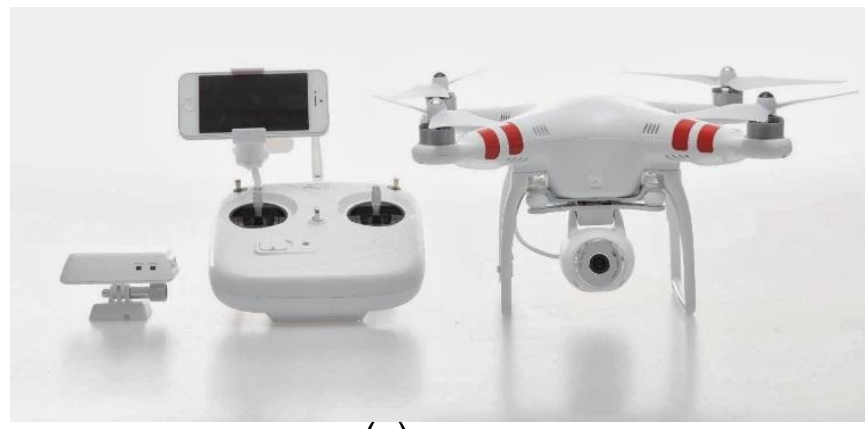

(a)

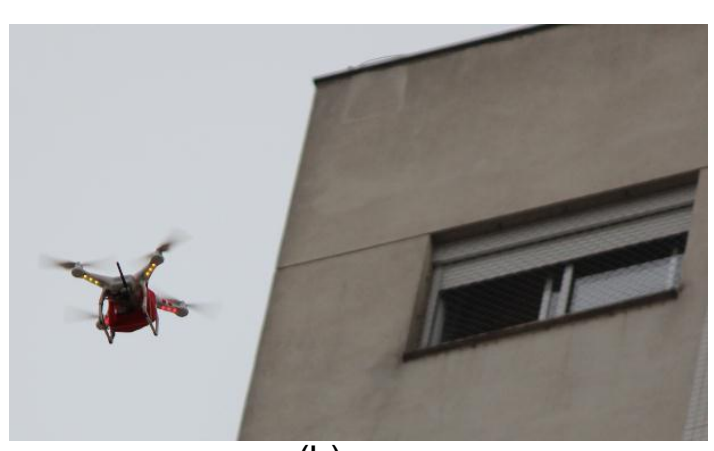

(b)

Figura 22. (a) Imagem do drone e acessórios utilizados; (b) Imagem do drone próximo à fachada (Fonte: Elaborado pelo autor).

\subsubsection{Moldagem dos painéis utilizados nas etapas de laboratório e campo}

A moldagem dos painéis seguiu as etapas do fluxograma ilustrado na Figura 23.

\begin{tabular}{|c|c|c|}
$\begin{array}{c}\text { Execução dos painéis } \\
\text { em alvenaria de tijolo } \\
\text { cerâmico e bloco de } \\
\text { concreto }\end{array}$ & $\begin{array}{c}\text { Preparo do substrato e } \\
\text { inclusão dos defeitos } \\
\text { sob a argamasáis dos } \\
\text { revestimento }\end{array}$ \\
$\begin{array}{c}\text { Assentamento e } \\
\text { rejuntamento do } \\
\text { revestimento cerâmico }\end{array}$ & $\begin{array}{c}\text { Inclusão dos } \\
\text { defeitos sob o } \\
\text { revestimento } \\
\text { cerâmico }\end{array}$ & $\begin{array}{c}\text { Mistura e aplicação de } \\
\text { argamassa de } \\
\text { revestimento } \\
\text { projetado }\end{array}$ \\
\hline
\end{tabular}

Figura 23. Etapas de moldagem dos painéis. 


\subsubsection{Estrutura dos painéis}

Os painéis foram executados em pórticos metálicos de dimensões 1,20 x 1,50 metros de vão e com rodas para dar mobilidade na área do laboratório durante a realização dos ensaios conforme ilustrado na Figura 24-a.

No total foram preparados seis painéis, dos quais três em alvenaria de bloco cerâmico e três em bloco de concreto. (Figura 24- b), ambos com dimensões de 19 x 19 x $39 \mathrm{~cm}$, normatizados (ABNT) e certificados. Como o estudo foi realizado com paredes de alvenaria, alvenaria revestida com argamassa e alvenaria revestida com argamassa mais cerâmica $10 \times 10 \mathrm{~cm}$, cada painel recebeu uma identificação na lateral (Figura 25-a) e no canto superior esquerdo do pórtico (Figura 25-b) pelas abreviações PCE (Painel de Tijolo Cerâmico) ou PCO (Painel de Bloco de Concreto), seguido por números de 1 a 3 e pela letra $A$ ou $B$, identificando a face.

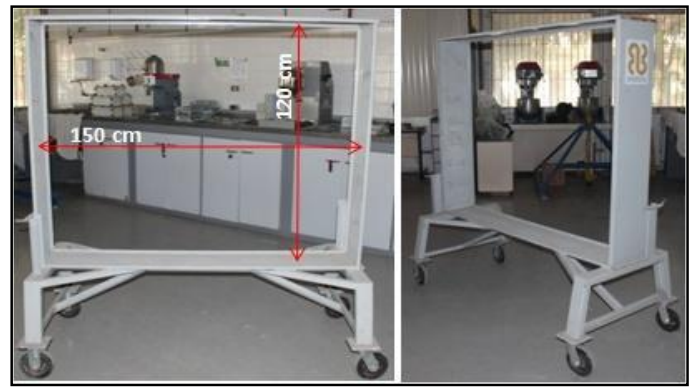

(a)

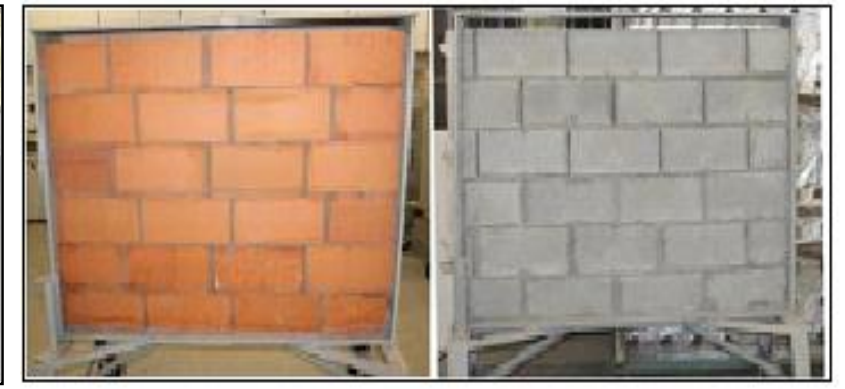

(b)

Figura 24. (a) Pórticos metálicos; (b) Painéis executadas com as alvenarias em tijolo cerâmico e bloco de concreto (Fonte: Elaborado pelo autor).

Painéis de tijolo cerâmico:

PCE 1-A: alvenaria + revestimento de argamassa

$>$ PCE 1-B: alvenaria

> PCE 2-A e B: alvenaria + revestimento de argamassa

PCE 3-A e B: alvenaria + revestimento de argamassa + revestimento cerâmico

Painéis de blocos de concreto:

$>$ PCO 1-A: alvenaria + revestimento de argamassa

PCO 1-B: alvenaria 
> PCO 2-A e B: alvenaria + revestimento de argamassa

PCO 3-A e B: alvenaria + revestimento de argamassa + revestimento cerâmico

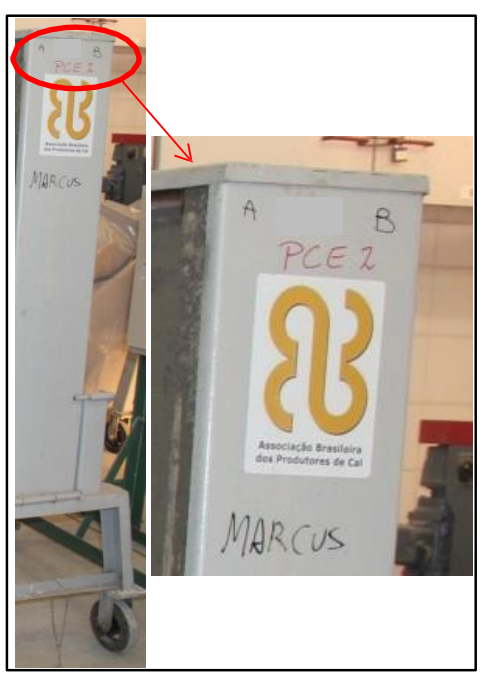

(a)

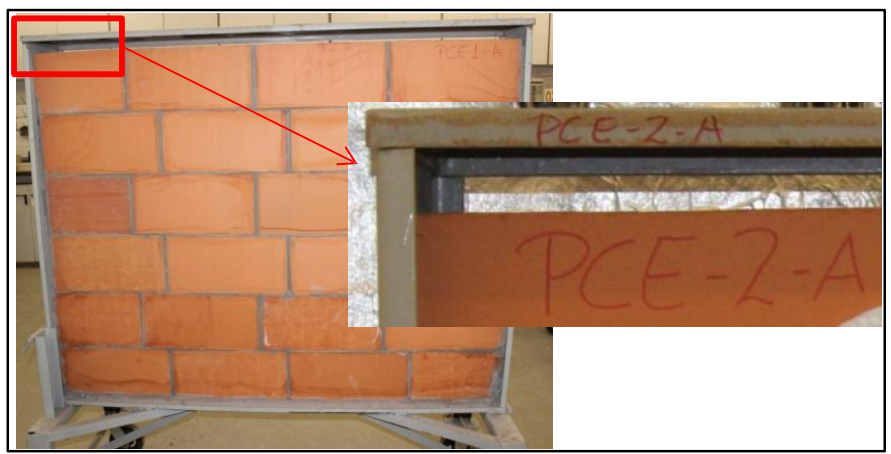

(b)

Figura 25. (a) Identificação lateral do painel; (b) Identificação frontal do painel (Fonte: Elaborado pelo autor).

\subsubsection{Defeitos}

No estudo, foram criados defeitos reais e simulados com diferentes formatos, dimensões e espessuras, utilizando isopor, EVA e plástico. Os defeitos foram posicionados na alvenaria, na interface alvenaria/reboco e na interface reboco/revestimento cerâmico, conforme detalhado:

- defeitos na alvenaria: fissuras e juntas verticais da alvenaria sem argamassa de assentamento

- defeitos no reboco: desplacamentos e fissuras

- defeitos no revestimento cerâmico: desplacamentos e vazios (falhas de assentamento)

Para cada face dos painéis foi definido um conjunto de defeitos conforme plano de moldagens na Tabela 5. 
Tabela 5. Tabela de planejamento de moldagens das paredes (Fonte: Elaborado pelo autor).

\begin{tabular}{|c|c|c|c|c|c|c|c|c|c|c|c|c|c|c|c|c|}
\hline \multirow[b]{3}{*}{ Painel } & \multirow[b]{3}{*}{ Face } & \multicolumn{15}{|c|}{ DEFEITOS } \\
\hline & & \multirow[b]{2}{*}{ 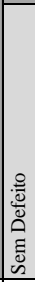 } & \multirow[b]{2}{*}{ 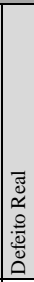 } & \multirow[b]{2}{*}{ 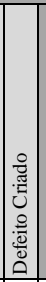 } & \multirow[b]{2}{*}{ Tipo } & \multicolumn{5}{|c|}{ Posição } & \multirow[b]{2}{*}{ Forma } & \multicolumn{3}{|c|}{ Dimensões } & \multirow[b]{2}{*}{$\begin{array}{l}\text { Espessura } \\
(\mathrm{mm})\end{array}$} & \multirow[b]{2}{*}{ Material } \\
\hline & & & & & & 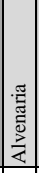 & 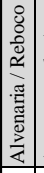 & 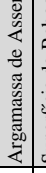 & 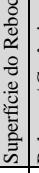 & 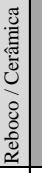 & & Dimensões (x,y) (mm) & Diâmetro (mm) & Largura $(\mathrm{mm})$ & & \\
\hline \multirow{4}{*}{ PCE1 } & \multirow{2}{*}{ A } & - & - & $\mathrm{x}$ & Vazios / Desplacamento & - & $\mathrm{x}$ & - & - & - & circulo & - & 275 & - & - & Plástico \\
\hline & & - & $\mathrm{x}$ & - & Falhas de preenchimento & $\mathrm{x}$ & - & $\mathrm{x}$ & - & - & - & - & - & 10 & - & - \\
\hline & \multirow{2}{*}{ B } & - & $\mathrm{x}$ & - & Fissuras & $\mathrm{X}$ & - & $\mathrm{x}$ & - & - & - & - & - & 1 & - & - \\
\hline & & - & $\mathrm{x}$ & - & Falhas de preenchimento & $\mathrm{X}$ & - & $\mathrm{x}$ & - & - & - & - & - & 10 & - & - \\
\hline \multirow{9}{*}{ PCE2 } & \multirow{8}{*}{ A } & \multirow{8}{*}{-} & \multirow{8}{*}{-} & & & & & & & & quadrado & $\begin{array}{c}200 \times 200 / 100 \times 100 / \\
50 \times 50 / 20 \times 20\end{array}$ & - & - & 2 & EVA \\
\hline & & & & & & & & & & & & - & $300 / 200 / 150$ & - & 10 & Isopor \\
\hline & & & & & & & & & & & circulo & - & $100 / 50 / 20$ & - & 5 & Isopor \\
\hline & & & & $\mathrm{x}$ & Vazios / Desplacamento & - & $\mathrm{x}$ & - & - & - & retângulo & $10 \times 100 / 20 \times 200$ & - & - & 2 & EVA \\
\hline & & & & & & & & & & & & $10 \times 100 / 10 \times 300$ & - & - & - & Madeira \\
\hline & & & & & & & & & & & cllindro & $20 \times 500$ & - & - & - & Silicone \\
\hline & & & & & & & & & & & esfera & - & $20 / 10$ & - & - & Isopor \\
\hline & & & & & & & & & & & $\begin{array}{l}\text { letras e números } \\
\text { (PCE 2 FA) }\end{array}$ & - & - & - & 5 & EVA \\
\hline & B & - & - & $\mathrm{X}$ & Vazios / Desplacamento & - & $\mathrm{x}$ & - & - & - & retângulo & - & $500 \times 600$ & - & 5 & Isopor \\
\hline & & & & & & & & & & & circulo & - & $300 / 200 / 150$ & - & 10 & Isopor \\
\hline & A & - & - & $\mathrm{x}$ & Vazios / Desplacamento & - & $\mathrm{x}$ & - & - & - & quadrado & $\begin{array}{c}300 \times 300 / 150 \times 150 / \\
100 \times 100 \\
\end{array}$ & - & - & 5 & Isopor \\
\hline & & - & $\mathrm{x}$ & - & Vazios / Desplacamento & - & - & - & - & $\mathrm{x}$ & & VAZIOS DE ARG & IAMASSA DE AS & SSENTAMENT & & \\
\hline & & - & - & $\mathrm{X}$ & Vazios / Desplacamento & - & $\mathrm{x}$ & - & - & - & retângulo & - & $500 \times 600$ & \begin{tabular}{|l|}
- \\
\end{tabular} & 5 & Isopor \\
\hline PCE3 & & & T & & & & & 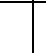 & & & circulo & - & 200 & - & 10 & Isopor \\
\hline & B & & & & & & & & & & quadrado & $200 \times 200$ & - & - & 5 & Isopor \\
\hline & & - & - & $\mathrm{x}$ & Vazios / Desplacamento & - & - & - & - & $x$ & retângulo & $10 \times 250$ & - & - & 2 & EVA \\
\hline & & & & & & & & & & & números (0 a 8) & - & - & - & 5 & EVA \\
\hline & A & - & - & $\mathrm{X}$ & Vazios / Desplacamento & - & $\mathrm{x}$ & - & - & - & circulo & - & 275 & - & - & Plástico \\
\hline $\mathrm{PCO} 1$ & A & - & $\mathrm{x}$ & - & Falhas de preenchimento & $\mathrm{x}$ & - & \begin{tabular}{l|l}
$x$ \\
\end{tabular} & - & - & - & - & - & 10 & - & - \\
\hline PCOT & B & - & $\mathrm{x}$ & - & Fissuras & $\mathrm{x}$ & - & $\mathrm{x}$ & - & - & - & - & - & 1 & - & - \\
\hline & B & - & $\mathrm{x}$ & - & Falhas de preenchimento & $\mathrm{X}$ & - & $\mathrm{x}$ & - & - & - & - & - & 10 & - & - \\
\hline & & & & & & & & & & & quadrado & $\begin{array}{c}200 \times 200 / 100 \times 100 / \\
50 \times 50 / 20 \times 20\end{array}$ & - & - & 2 & EVA \\
\hline & & & & & & & & & & & circulo & - & $300 / 200 / 150$ & - & 8 & Isopor \\
\hline & & & & & & & & & & & circulo & - & $100 / 50 / 20$ & - & 5 & Isopor \\
\hline & A & - & - & $\mathrm{x}$ & Vazios / Desplacamento & - & $\mathrm{x}$ & - & - & - & retângulo & $10 \times 100 / 20 \times 200$ & - & - & 2 & EVA \\
\hline $\mathrm{PCO} 2$ & & & & & & & & & & & cilindro & $10 \times 100 / 10 \times 300$ & - & - & - & Madeira \\
\hline & & & & & & & & & & & culindro & $20 \times 500$ & - & - & - & Silicone \\
\hline & & & & & & & & & & & esfera & - & $20 / 10$ & - & - & Isopor \\
\hline & & & & & & & & & & & $\begin{array}{l}\text { letras e números } \\
\text { (PCO 2 FA) }\end{array}$ & - & - & - & 5 & EVA \\
\hline & B & - & - & $x$ & Vazios / Desplacamento & - & $\mathrm{x}$ & - & - & - & retângulo & - & $500 \times 600$ & - & 5 & Isopor \\
\hline & & & & & & & & & & & circulo & - & $300 / 200 / 150$ & - & 10 & Isopor \\
\hline & & - & - & $\mathrm{x}$ & Vazios / Desplacamento & - & $\mathrm{x}$ & - & - & - & quadrado & $\begin{array}{c}300 \times 300 / 150 \times 150 / \\
100 \times 100\end{array}$ & - & - & 5 & Isopor \\
\hline & A & & & & & & & & & & circulo & - & $200 / 100 / 50$ & - & 10 & Isopor \\
\hline $\mathrm{PCO} 3$ & & - & - & $\mathrm{x}$ & Vazios / Desplacamento & - & - & - & - & $\mathrm{x}$ & quadrado & $200 \times 200 / 50 \times 50$ & - & - & 5 & Isopor \\
\hline & & & & & & & & & & & retângulo & $10 \times 250$ & - & - & 2 & EVA \\
\hline & $B$ & - & - & $\mathrm{x}$ & Vazios / Desplacamento & - & $\mathrm{x}$ & - & - & - & circulo & - & $300 / 200$ & - & 5 & Isopor \\
\hline & & - & $\mathrm{x}$ & - & Vazios / Desplacamento & - & - & - & - & $\mathrm{x}$ & & VAZIOS DE ARG & IAMASSA DE AS & ENTAME & & \\
\hline
\end{tabular}


Os painéis foram divididos em dois quadrantes (Figura 26), com o objetivo de localizar os defeitos sobre o substrato e, através dos termogramas, facilitar as análises de posicionamento dos defeitos.

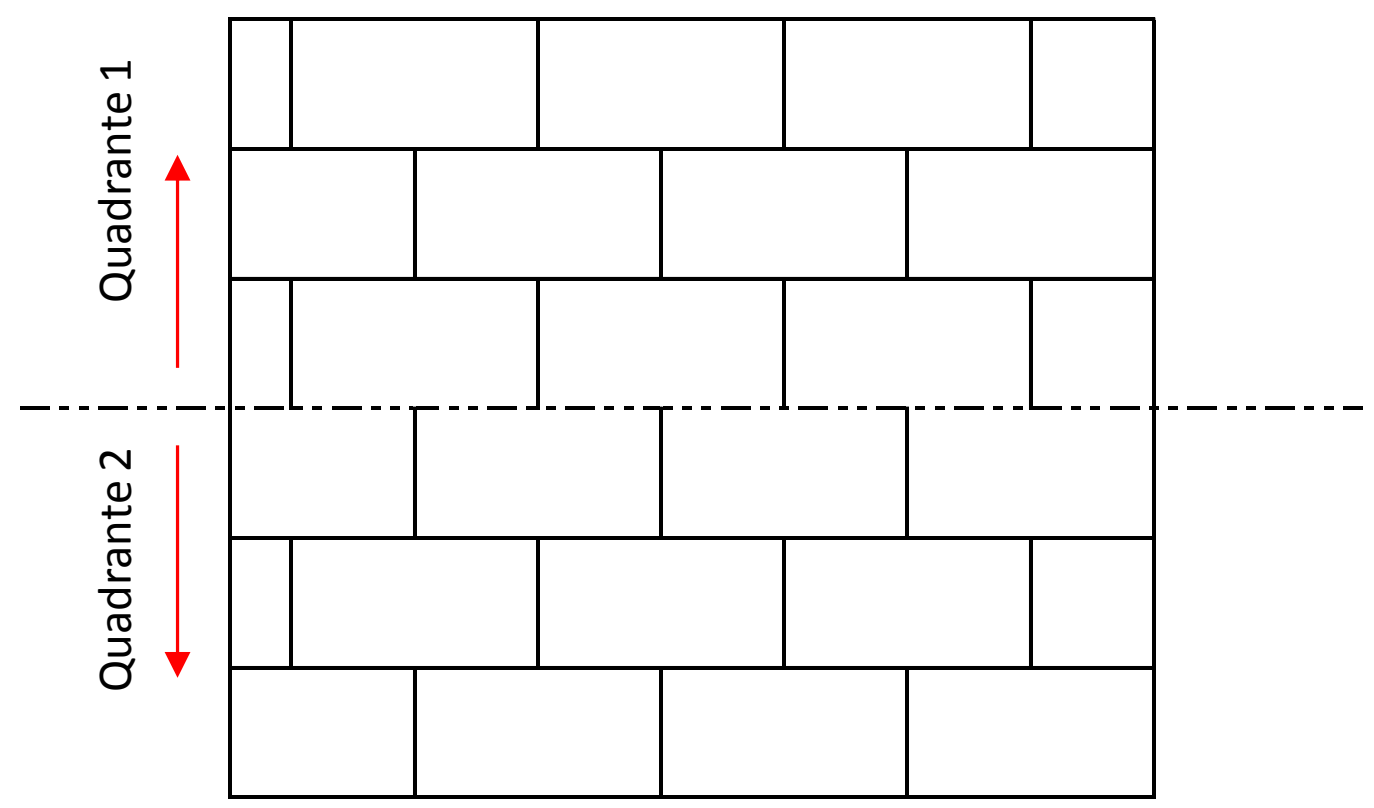

Figura 26. llustração dos quadrantes em cada painel (Fonte: Elaborado pelo autor).

\subsubsection{Preparo do substrato e inclusão dos defeitos}

O procedimento de moldagem foi iniciado pela limpeza das paredes com jato de ar comprimido.

Conforme ilustração na Figura 27-a, no painel PCE1, os defeitos de fissuras da argamassa de assentamento da alvenaria foram criados com a vibração do painel durante movimentação sobre superfície irregular. No painel PCO1 as fiadas do quadrante 1 foram assentadas sem argamassa na junta vertical, que variaram de 5 a $10 \mathrm{~mm}$ (Figura 27-b).

O vazio sob a argamassa de revestimento no painel PCO1-A foi criado com auxílio de um círculo de plástico de 270 milímetros de diâmetro fixado apenas pelas extremidades na alvenaria conforme detalhado na Figura 28. 


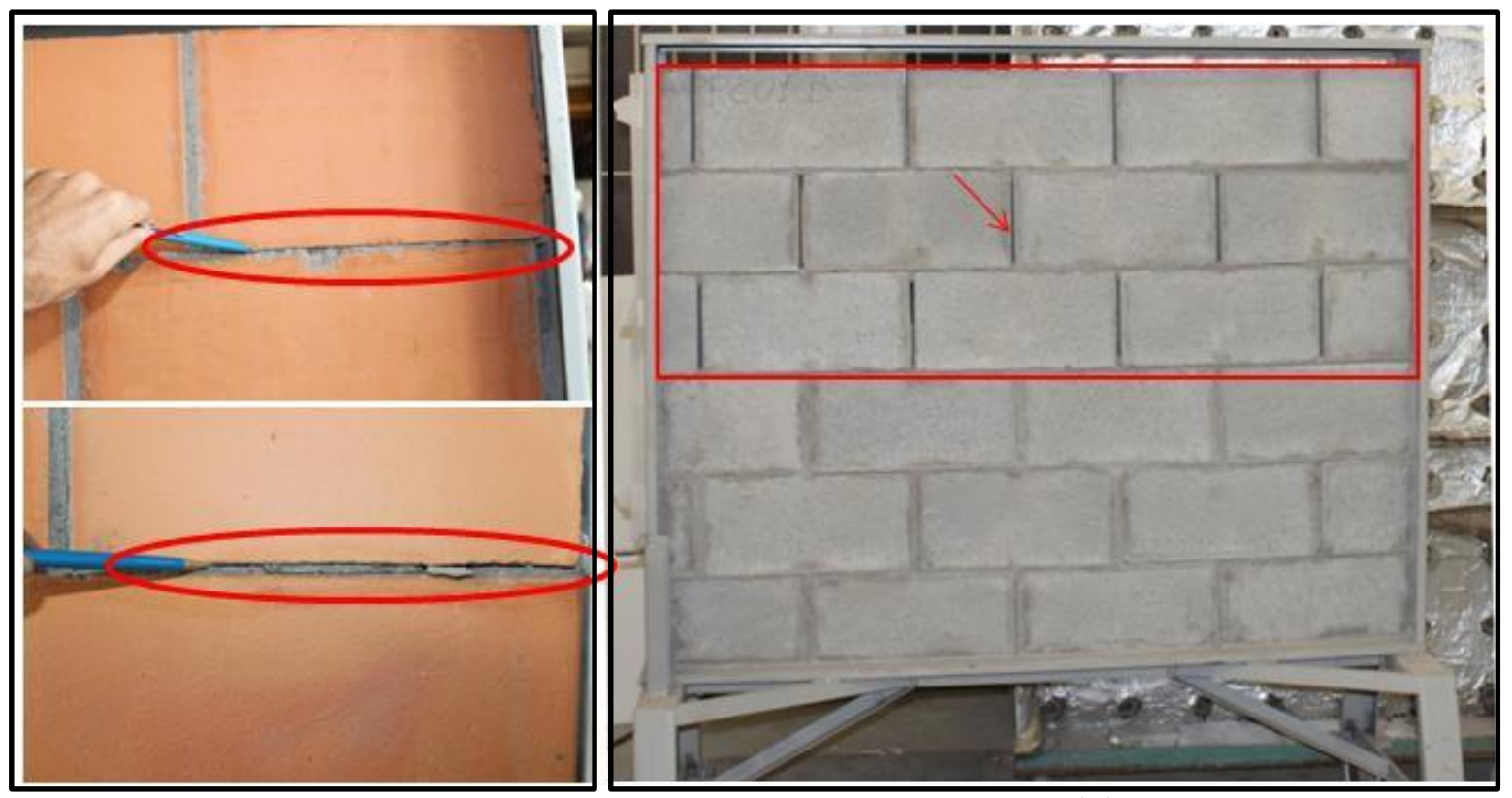

(a)

(b)

Figura 27. Criação de defeitos reais na alvenaria de bloco cerâmico e concreto: (a) defeito de fissura na argamassa de assentamento da alvenaria no painel PCE1; (b) ausência de argamassa de assentamento na junta vertical da alvenaria. (Fonte: Elaborado pelo autor).

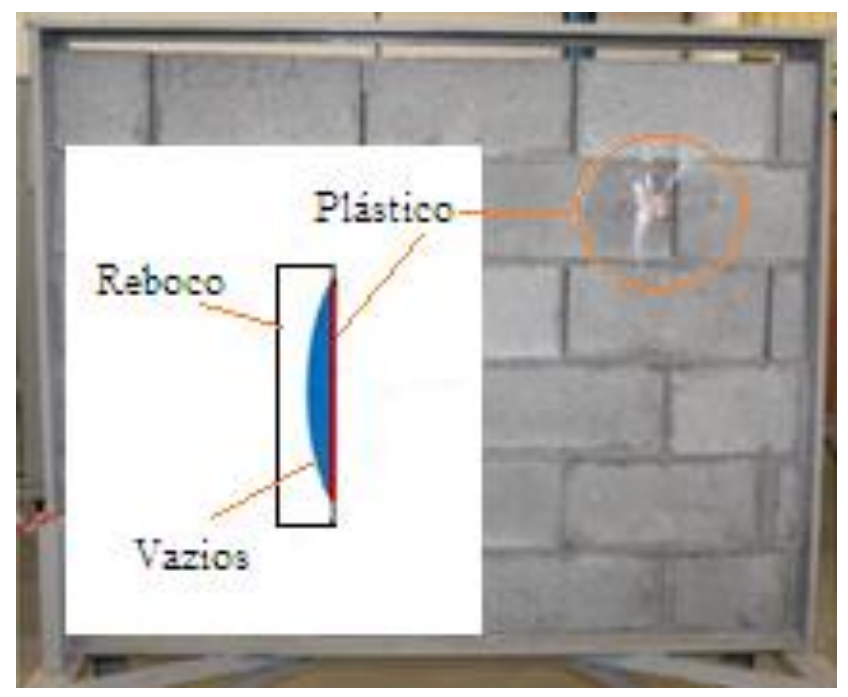

Figura 28. Ilustração esquemática da criação de vazios na interface entre alvenaria e reboco (Fonte: Elaborado pelo autor).

De acordo com a Figura 29-a, Figura 29-b, Figura 29-c e Figura 29-d, os defeitos de desplacamentos dos painéis PCO2, PCO3, PCE2 e PCE3 respectivamente, foram posicionados e fixados na alvenaria utilizando cola para isopor e cola instantânea Super Bonder seguindo o plano de moldagem. 

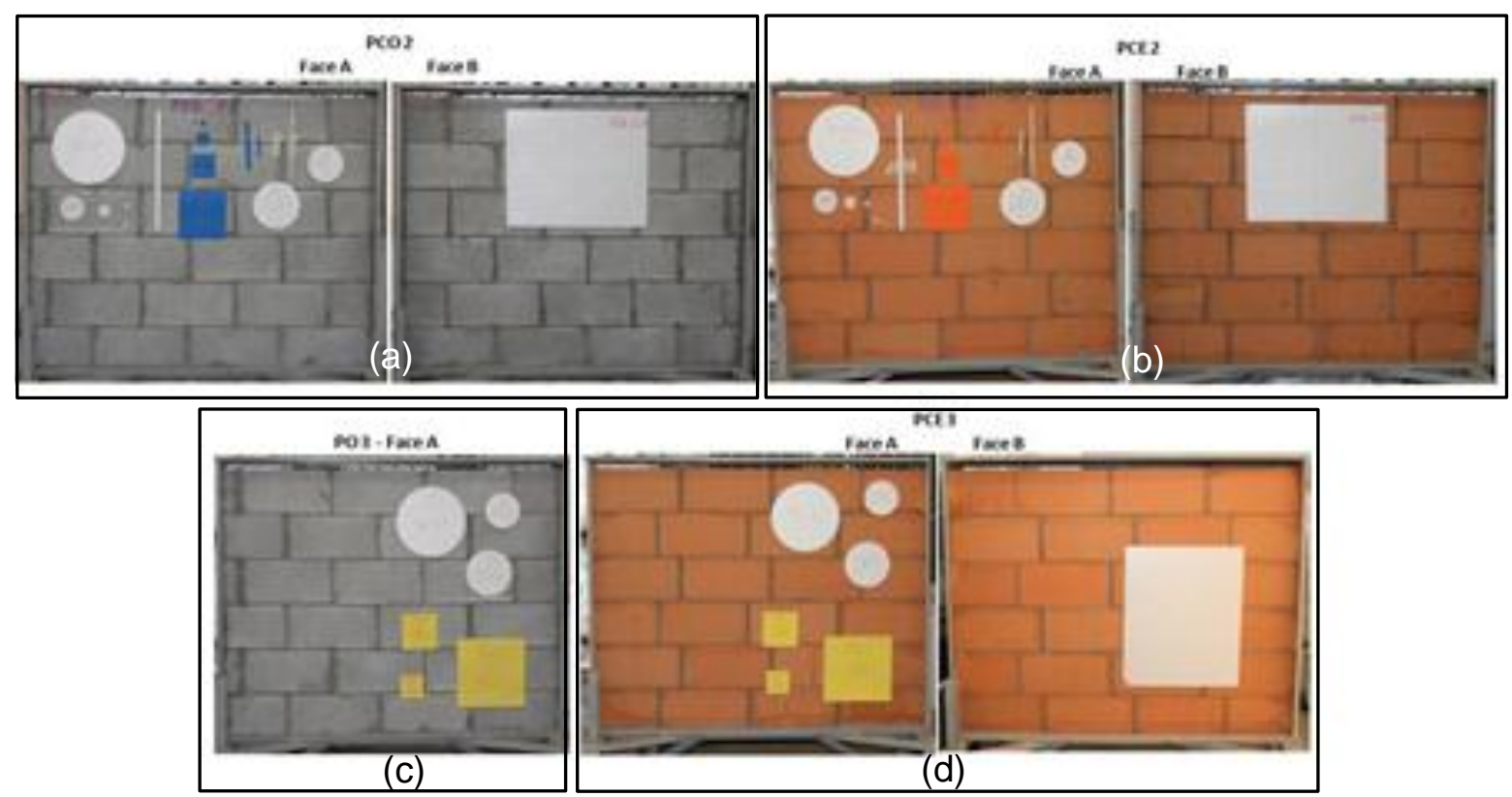

Figura 29. Posicionamento e fixação dos defeitos nos painéis de acordo com o plano de ensaio: (a) PCO2-A e B; (b) PCE2-A e B; (c) PCO3-A; (d) PCE3-A e B. (Fonte: Elaborado pelo autor).

$\mathrm{Na}$ sequência foram fixados os limitadores de espessura da argamassa de revestimento, parafusando réguas de alumínio com 2,5 centímetros de espessura nas extremidades à direita e à esquerda de cada parede, paralelos às bordas laterais do pórtico, conforme detalhado na Figura 30.

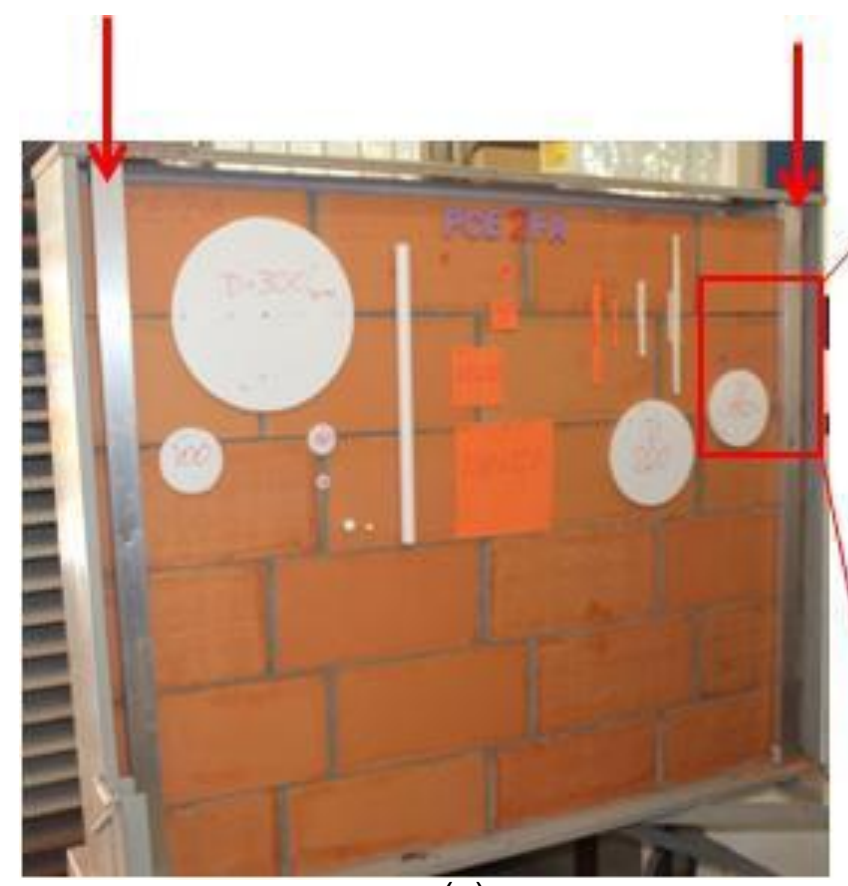

(a)

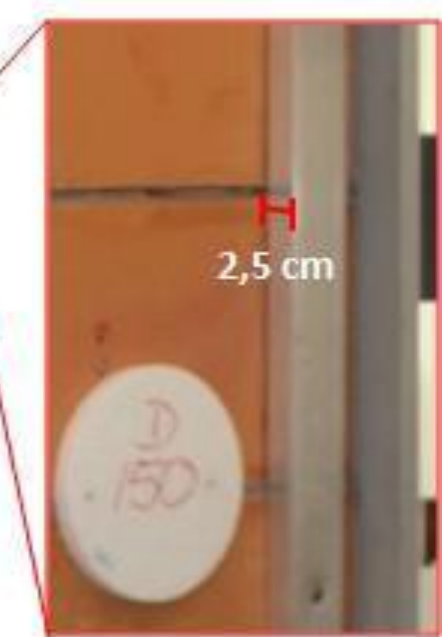

(b)

Figura 30. (a) Fixação dos limitadores de espessura de argamassa de regularização nos painéis de alvenaria; (b) detalhe. (Fonte: Elaborado pelo autor). 


\subsubsection{Mistura e aplicação de argamassa projetada}

Em todas as etapas de estudos foram utilizadas argamassa de projeção industrializada, todas de um mesmo palete com 40 sacos de $50 \mathrm{~kg}$, produzidas em uma mesma batelada, conforme data e no de lote de produção registrados na embalagem (Figura 31), dessa forma, considerou-se o produto de cada saco uniforme.

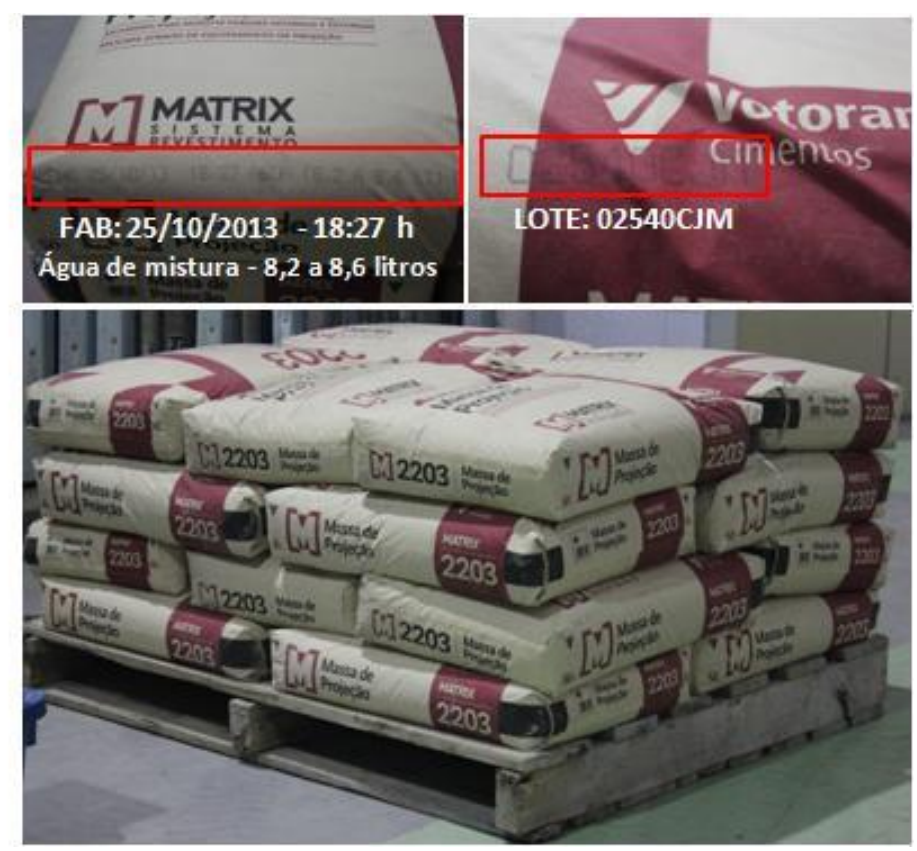

Figura 31. Identificação de data de fabricação, volume de água de mistura e lote de fabricação, volume de água de mistura e lote de fabricação da argamassa de projeção utilizada na moldagem dos CPs (Fonte: Elaborado pelo autor).

Como o foco deste trabalho está na aplicação das técnicas de ensaios não destrutivos, a caracterização da argamassa foi feita de forma superficial atentando-se somente para os aspectos físicos do produto.

A argamassa apresenta distribuição granulométrica, conforme indicado na Figura 32a e Figura 32-b, densidade real de $1750 \mathrm{~g} / \mathrm{cm}^{3}$ e área superficial específica total de $5000 \mathrm{~m}^{2} / \mathrm{g}$. 


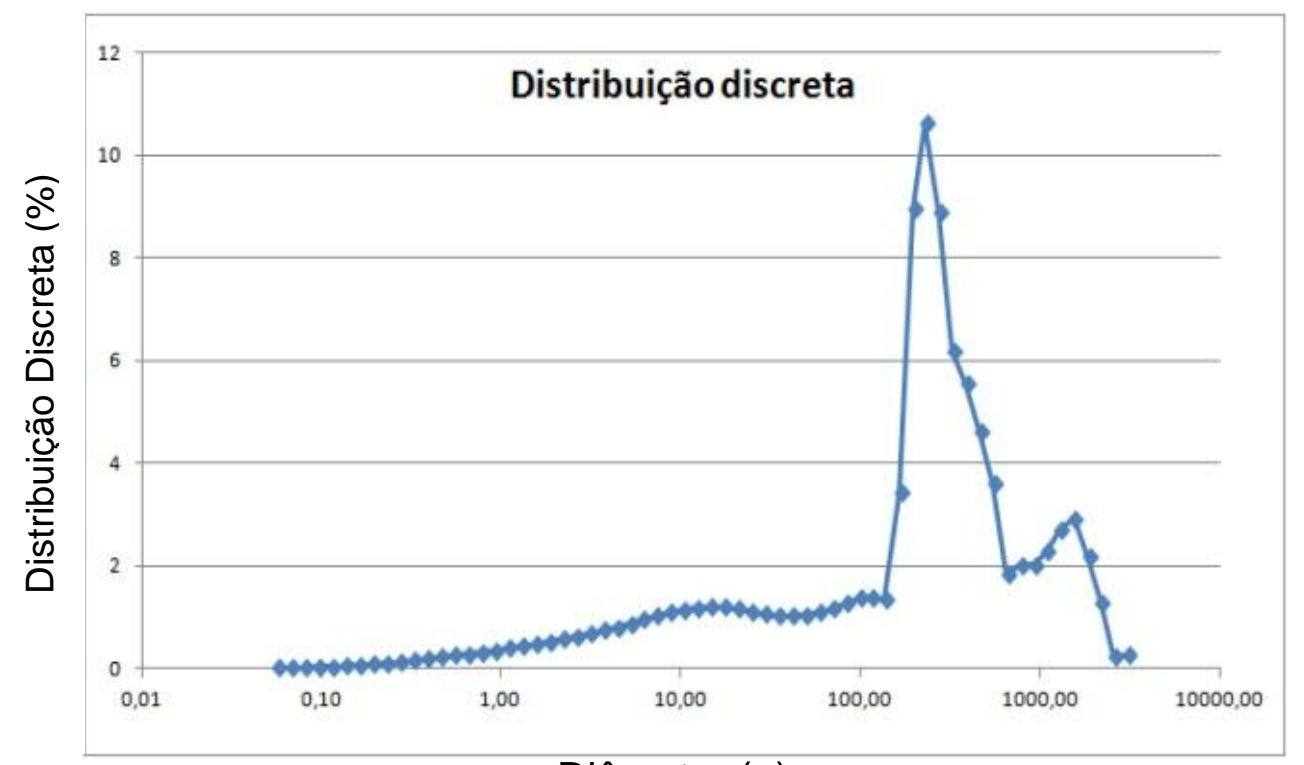

(a)

Diâmetro $(\mu)$

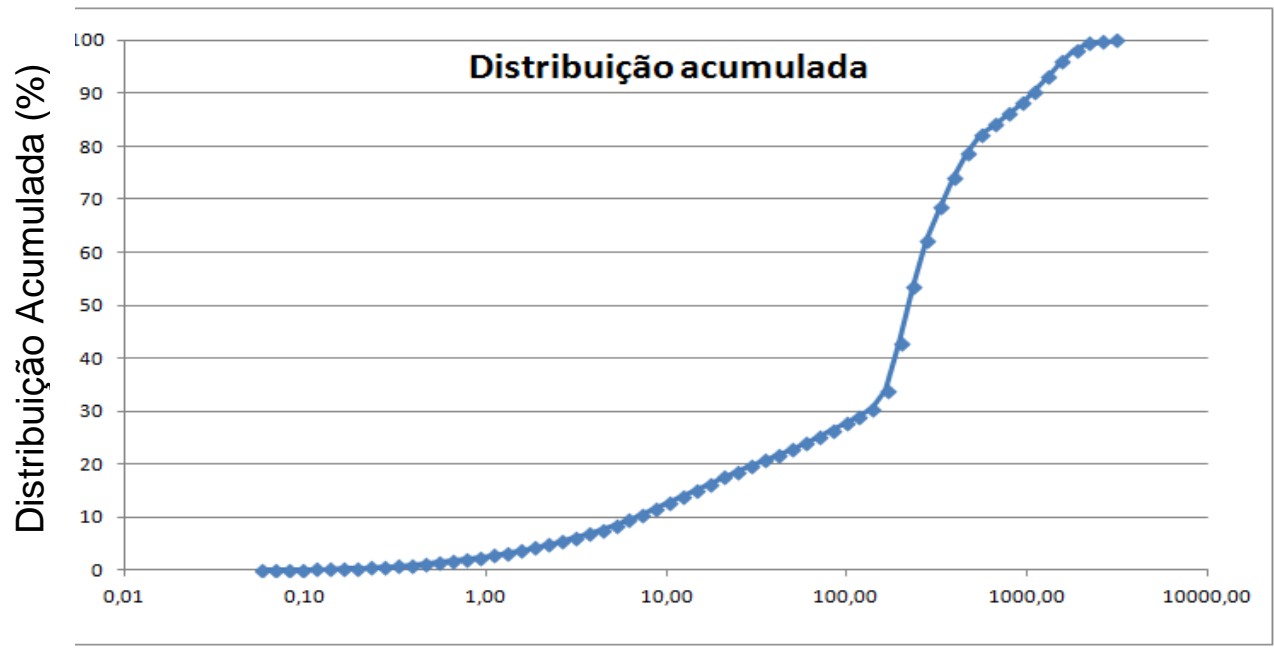

(b)

Diâmetro $(\mu)$

Figura 32. (a) Gráfico de distribuição discreta e (b) Gráfico de distribuição acumulada (Fonte: Elaborado pelo autor).

As misturas da argamassa foram realizadas em laboratório com 17,2\% de água, conforme indicação do fabricante, resultando em uma consistência adequada para aplicação via projeção com uso do conjunto misturador por batelada (

Figura 33-a) e projetora de argamassa (

Figura 33-b). 
Nas faces dos painéis sem defeitos a argamassa foi aplicada em única etapa, conforme ilustrado na Figura 34. Nos painéis com defeitos, a aplicação ocorreu em duas etapas com intervalo de 10 minutos entre elas para evitar o escorrimento/desplacamento da argamassa, já que o isopor e o EVA não absorvem água (Figura 35-a). Nos casos dos defeitos maiores (Figura 36-a), primeiro projetou-se uma fina camada de argamassa (Figura 36-b) e após aproximadamente 30 minutos completou-se o preenchimento. O sarrafeamento e acabamento da argamassa de revestimento foram executados com a argamassa ainda no estado plástico utilizando a "régua H" (Figura 35-b), ferramenta que facilita o corte no estado fresco para deixar o revestimento plano e nivelado.

No início da projeção, o ar incorporado mensurado foi de 27,5\%. Deve ser salientado que o desvio médio do ar incorporado das medições foi de 2,1\% indicando bom controle da mistura e uniformidade da aplicação.

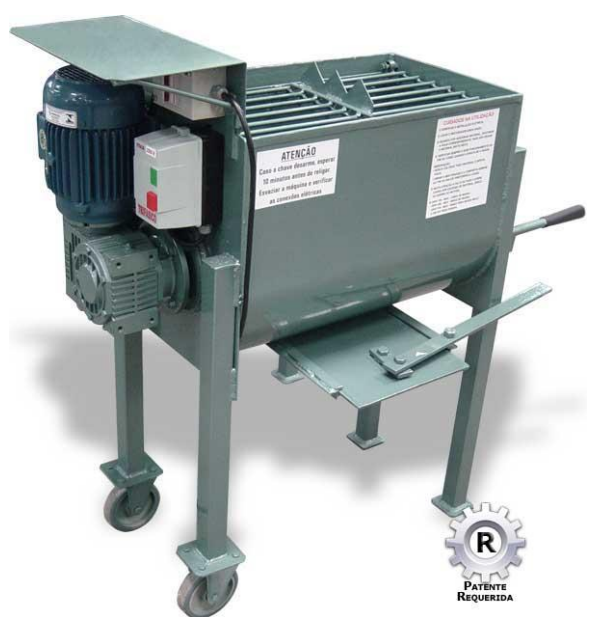

(a)

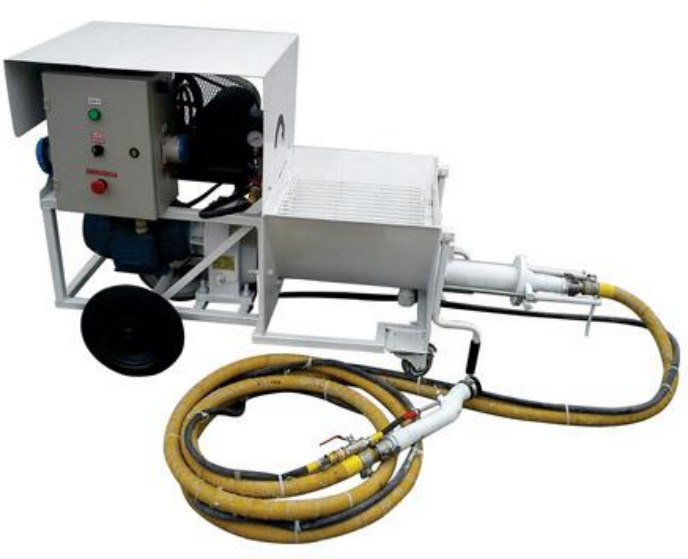

(b)

Figura 33. (a) Misturador de argamassa por batelada; (b) Projetor de argamassa. (Fonte: Elaborado pelo autor). 


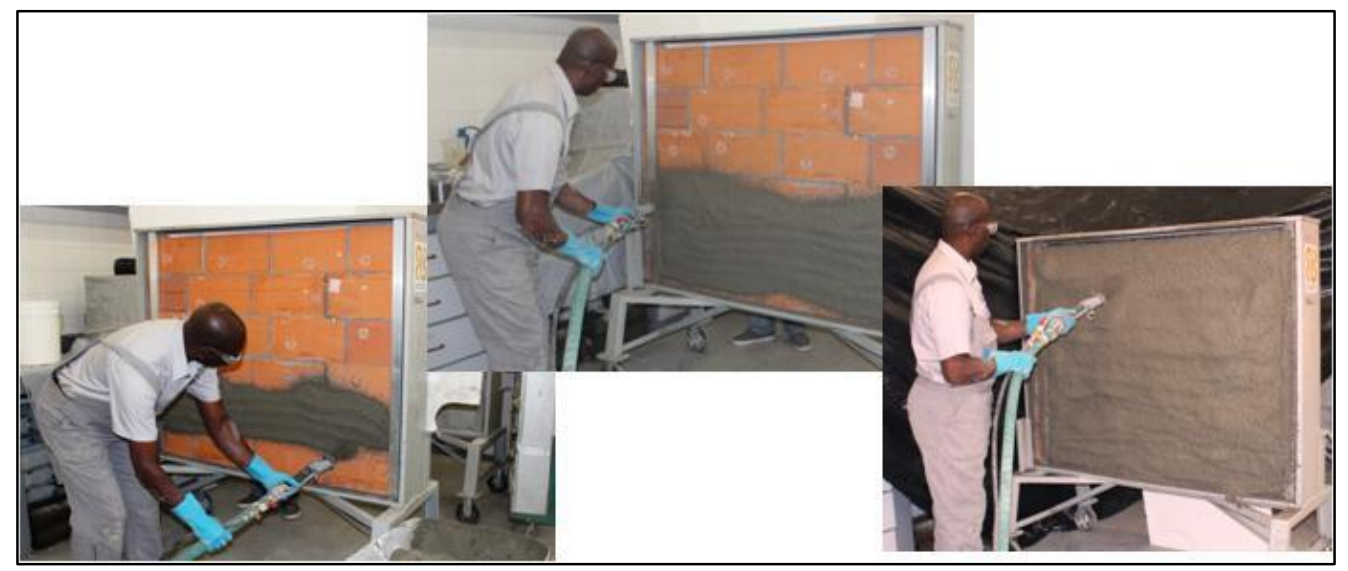

Figura 34. Sequência de aplicação de argamassa de projeção sobre parede sem defeitos (Fonte: Elaborado pelo autor).

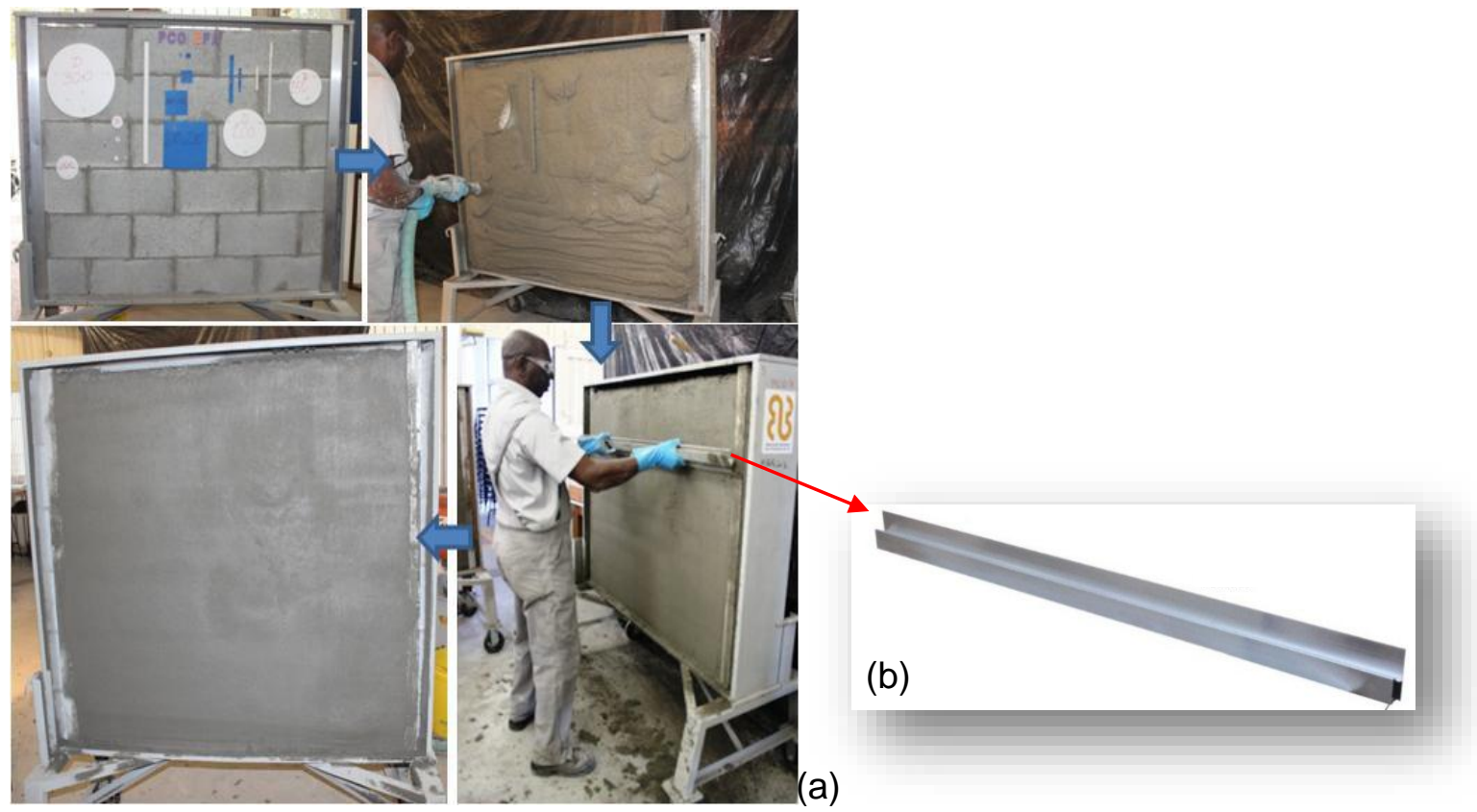

Figura 35. (a) Sequência de aplicação de argamassa de projeção em duas camadas sobre parede com diferentes tipos de defeitos; (b) Régua H. (Fonte: Elaborado pelo autor).

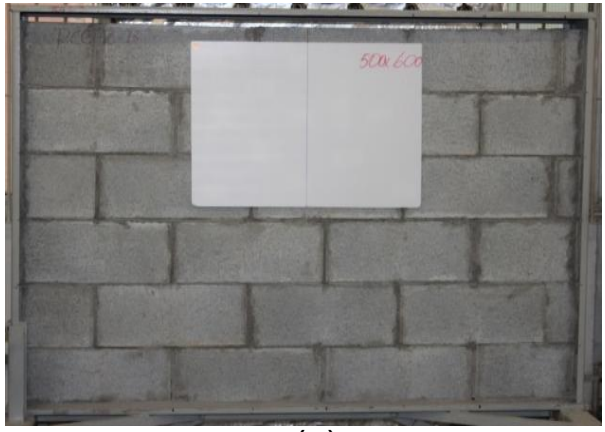

(a)

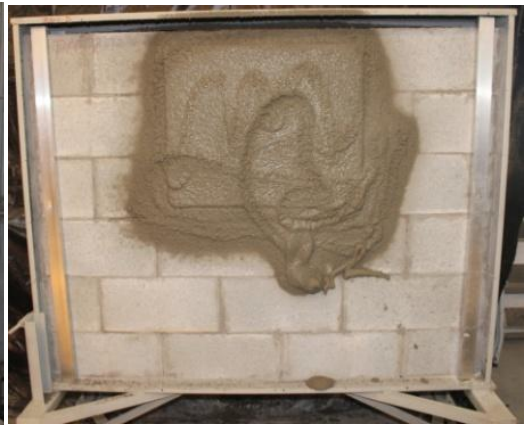

(b)

Figura 36. (a) Defeito de desplacamento aplicado sobre a alvenaria; (b) Aplicação de camada de argamassa de projeção sobre o defeito para evitar o escorrimento ou desplacamento da argamassa. (Fonte: Elaborado pelo autor). 
$\mathrm{Na}$ criação dos defeitos reais de fissura de retração no reboco, a Figura 37 mostra que os painéis PCE1 e PCO1 face "A" foram submetidos a aquecimento com painel térmico imediatamente após a finalização do reboco.

Não foi realizada cura úmida nas argamassas de revestimento dos painéis e finalizadas as moldagens; os painéis foram estocados e mantidos sem movimentação por 28 dias.

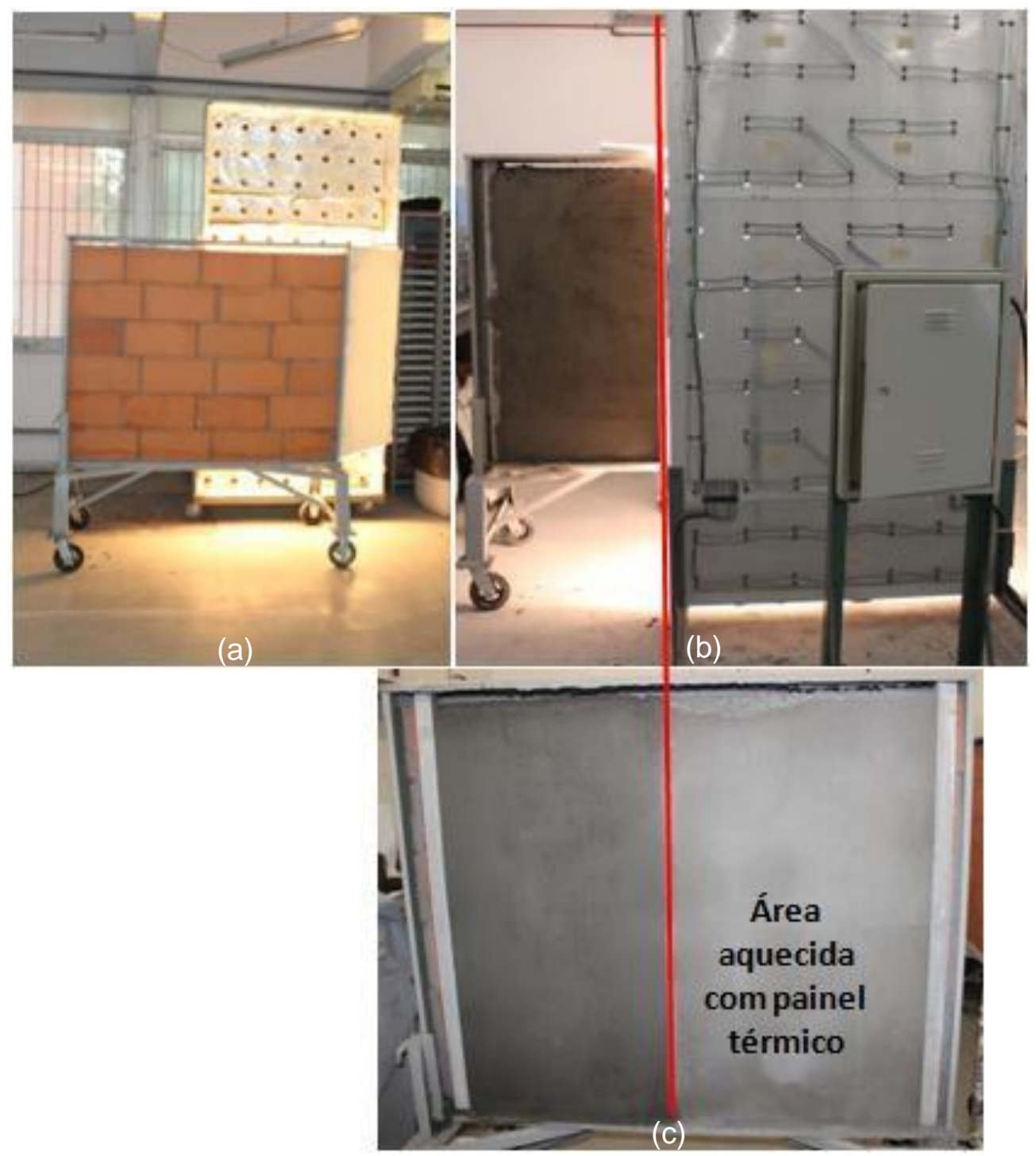

Figura 37. Aquecimento de metade de uma das faces do painel para criar fissuras de retração no reboco: (a) vista frontal do painel térmico; (b) vista posterior do painel térmico;

(c) vista do painel após aquecimento. (Fonte: Elaborado pelo autor). 


\subsubsection{Aplicação da cerâmica}

Os painéis PCE3 e PCO3 receberam o revestimento cerâmico após a realização dos termogramas do reboco com os defeitos de desplacamento.

Foram assentadas, de forma intercalada, cerâmicas com tonalidades claras (branca) e escuras (azul) e superfícies foscas e brilhantes com defeitos de desplamentos e vazios de argamassa colante inseridos na interface reboco/cerâmica para análises posteriores (Figura 38, Figura 39, Figura 40 e Figura 41). O assentamento foi realizado com argamassa do tipo AC-II do mercado e o procedimento de mistura seguiu as orientações do fabricante.

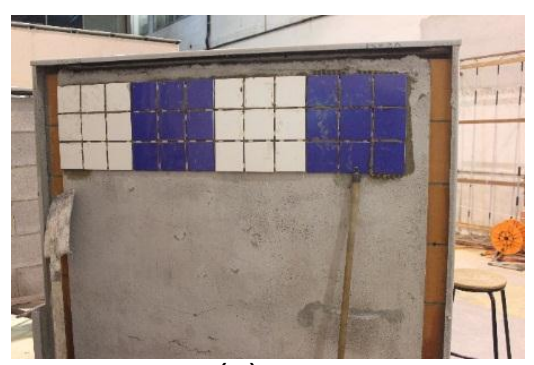

(a)

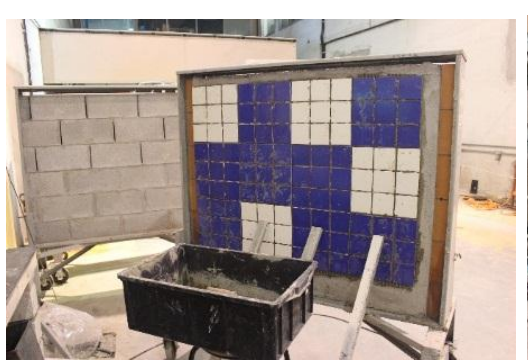

(b)

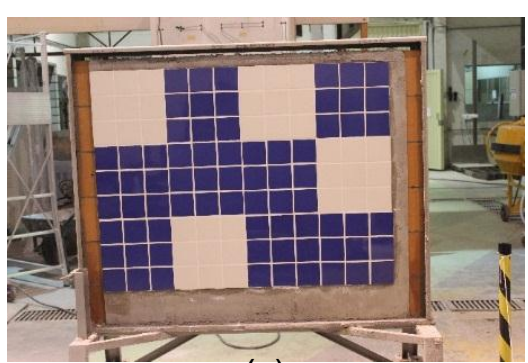

(c)

Figura 38. Sequência de assentamento de revestimento cerâmico no painel PCE3-A: (a) início do assentamento; (b) final do assentamento; (c) após rejuntamento. (Fonte: Elaborado pelo autor).

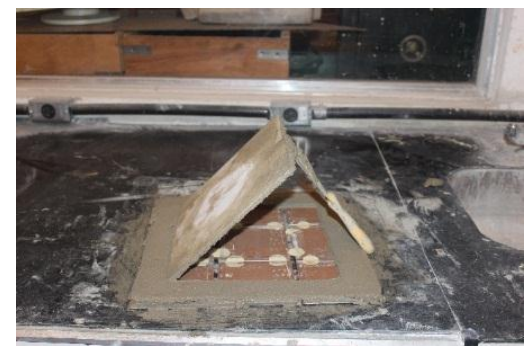

(a)

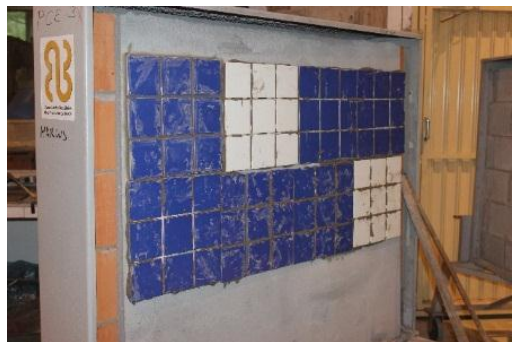

(b)

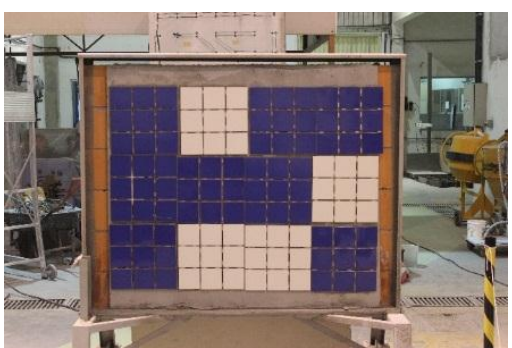

(c)

Figura 39. Sequência de assentamento de revestimento cerâmico no painel PCE3-B: (a) execução de vazio quadrado de $200 \times 200$ mm sob o revestimento cerâmico; (b) execução da segunda fiada; (c) painel sem rejunte. (Fonte: Elaborado pelo autor). 


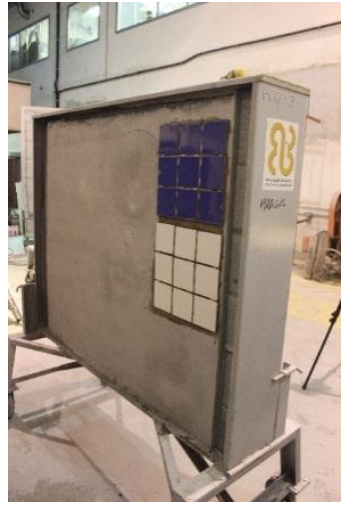

Figura 40. Sequência de assentamento (b) de revestimento cerâmico no painhel PCO3-A: (a)

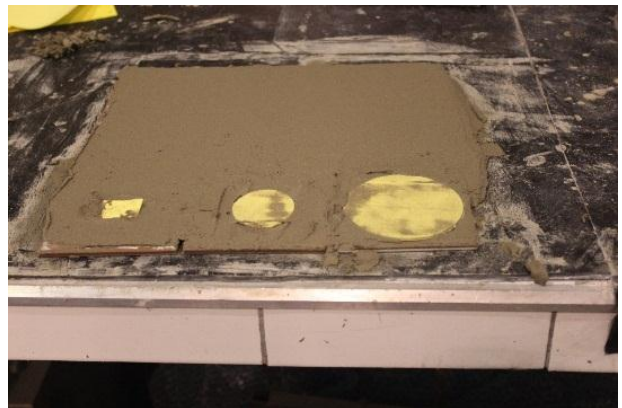

Figura 40. Sequência de assentamento (b) de revestimento cerâmico no painhel PCO3-A: (a)

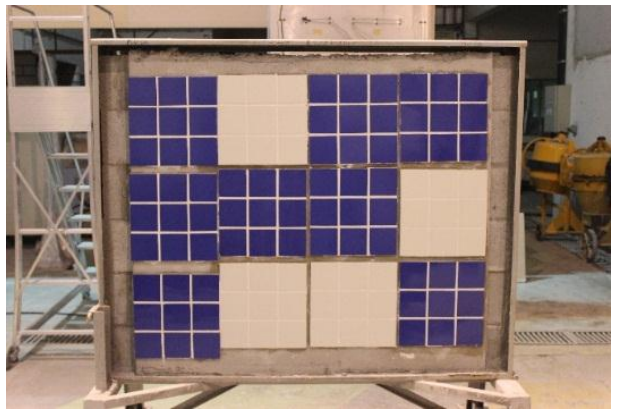

Figura 40.) Sequência de assentamento de revestimento cerâmico no palinel PCO3-A: (a) Início do assentamento; (b) detalhe de defeitos circulares de $100 \mathrm{~mm}$ e $50 \mathrm{~mm}$ de diâmetro e defeito quadrado de $500 \mathrm{~mm}$ de lado; (c) painel rejuntado. (Fonte: Elaborado pelo autor).

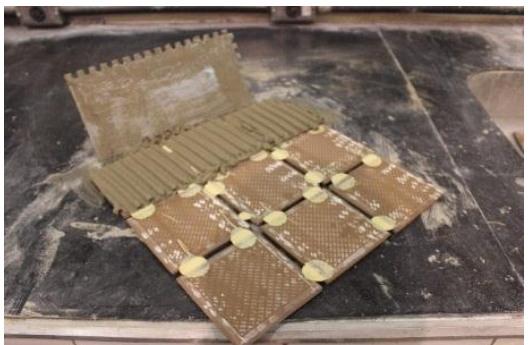

(a)

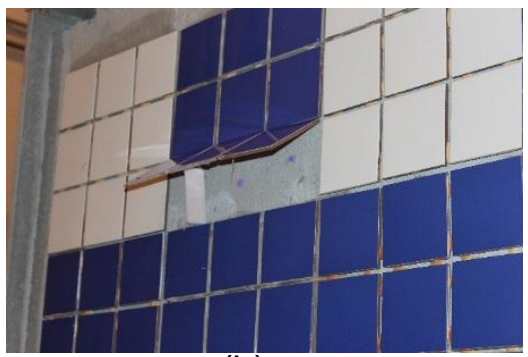

(b)

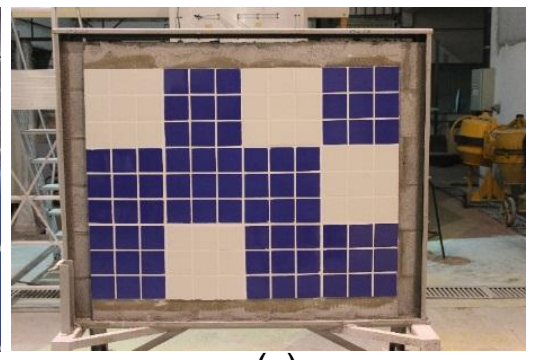

(c)

Figura 41. Sequência de assentamento de revestimento cerâmico no painel PCO3-B: (a) detalhe de defeitos vazios de argamassa; (b) detalhe de defeito após aplicação (c) painel rejuntado. (Fonte: Elaborado pelo autor).

\subsubsection{Condição de contorno para realização dos termogramas}

Diferentes situações podem gerar interferências que alteram a condição natural da superfície em análise, levando a interpretações equivocadas dos termogramas; dessa forma, foram consideradas algumas condições para garantir uniformidade na leitura dos painéis e fachadas permitindo a melhor interpretação dos termogramas.

Nas etapas de Laboratório e campo foram considerados os seguintes pontos:

- argamassas de assentamento de alvenaria e de revestimento no estado endurecido a partir de 28 dias da data da moldagem.

- revestimento cerâmico assentado a partir de 28 dias da data da moldagem.

- aquecimento das faces dos painéis a serem ensaiadas apenas através de incidência direta de radiação térmica simulando a condição de fachada. Para cumprir essa condição, as leituras térmicas na etapa de laboratório foram realizadas apenas durante o resfriamento das faces, já que durante o aquecimento as superfícies em estudo ficam obstruídas pelo painel térmico e 
na etapa de campo durante o aquecimento (exposição ao sol) e resfriamento das faces (sombra) já que as superfícies em estudo não ficam obstruídas durante o aquecimento.

As condições de contorno in situ são:

- escolha dos sites: as medições in situ ocorreram nas fachadas de diferentes edifícios revestidos com pintura e/ou cerâmica localizados nas cidades de são paulo e brasília com defeitos de fissuras e desplacamentos de revestimentos similares aos analisados nos painéis moldados para as etapas de laboratório e campo.

- uso da energia solar acumulada pelas fachadas para gerar diferenças de temperaturas entre as regiões de defeitos e não defeitos.

- tempo de exposição ao sol.

\subsubsection{Características preliminares de ensaio}

Em razão da grande quantidade de informações a serem observadas antes dos ensaios e coletadas durante e após os mesmos foi estabelecido previamente um conjunto de características padrão para cada etapa experimental (Tabela 6).

Apenas para as etapas de laboratório e campo também foi estabelecido um conjunto de dados que caracterizam cada ensaio, sendo eles:

- número do ensaio

- painel e face/fachada ensaiada

- superfície analisada

- emissividade da superfície

- tipo de defeito 
Tabela 6. Características padrão para cada etapa experimental (Fonte: Elaborado pelo autor).

\begin{tabular}{|c|c|c|c|}
\hline \multirow{2}{*}{$\begin{array}{c}\text { CARACTERÍSTICAS } \\
\text { PRELIMINARES DE ENSAIO }\end{array}$} & \multicolumn{2}{|c|}{ ETAPAS EXPERIMENTAIS } & \multirow{2}{*}{\begin{tabular}{|c} 
ETAPAS EXPERIMENTAIS \\
In site \\
\end{tabular}} \\
\hline & \begin{tabular}{|l|l} 
Laboratório &
\end{tabular} & Campo & \\
\hline Tipo de abordagem térmica & Ativa & Passiva & Passiva \\
\hline Fonte de radiação & Forçada - Painel térmico & Natural - sol & Natural - sol \\
\hline Incidência de radiação & \begin{tabular}{|c|} 
Direta \\
\end{tabular} & Direta & Direta \\
\hline Condição de leitura térmica & Resfriamento & $\begin{array}{l}\text { Aquecimento / } \\
\text { Resfriamento }\end{array}$ & Aquecimento / Resfriamento \\
\hline Fonte de resfriamento & $\begin{array}{c}\text { Ambiente / Forçada } \\
\text { com painel de } \\
\text { resfriamento }\end{array}$ & Ambiente & Ambiente \\
\hline $\begin{array}{l}\text { Temperatura ambiente e } \\
\text { umidade }\end{array}$ & Não controlada & Não controlada & Não controlada \\
\hline $\begin{array}{l}\text { Espessura da argamassa de } \\
\text { reboco }\end{array}$ & Constante $-2,5 \mathrm{~cm}$ & Constante $-2,5 \mathrm{~cm}$ & Variada \\
\hline $\begin{array}{l}\text { Intervalo entre imagens } \\
\text { térmicas }\end{array}$ & 5 minutos & 5 minutos & Não controlada \\
\hline $\begin{array}{l}\text { Tempo de exposição da } \\
\text { superfície ao aquecimento }\end{array}$ & $\begin{array}{l}\text { - } 16 \text { a } 20 \text { minutos para } \\
\text { alvenaria e reboco } \\
\text { - } 12 \text { a } 14 \text { minutos para } \\
\text { revestimento cerâmico }\end{array}$ & Não controlada & Não controlada \\
\hline $\begin{array}{l}\text { Tempo de exposição ao } \\
\text { resfriamento }\end{array}$ & 5 minutos & Não controlada & Não controlada \\
\hline Tempo de leitura & até o equilíbrio térr & nico do painel & Não controlada \\
\hline $\begin{array}{l}\text { Distância entre câmera } \\
\text { térmica e painel }\end{array}$ & $323 \mathrm{~cm}$ & $323 \mathrm{~cm}$ & Variada \\
\hline
\end{tabular}

\subsubsection{Ciclos de aquecimento e resfriamento}

A energia emitida por uma superfície é afetada pelas propriedades do corpo e os defeitos resultam em alterações na temperatura superficial permitindo a sua análise (RAO, 2008). Os defeitos foram avaliados pela diferença de temperatura entre a zona defeituosa e sem defeito, usando ciclo dinâmico de aquecimento e resfriamento. Processo, em parte, similar ao utilizado no trabalho de Barreira et al. (2014).

- Painel térmico de aquecimento

Como fator causador das mudanças de temperatura da superfície a ser analisada pode-se utilizar fontes artificiais de calor ou fontes naturais, como o sol (EDIS et al., 2014). O aquecimento das paredes na etapa de Laboratório foi realizado artificialmente por meio de painel térmico ilustrado na Figura 42, cujo calor é gerado por um conjunto de lâmpadas incandescentes de 150W. Já nas etapas de campo e obra o aquecimento foi por incidência direta do sol. 


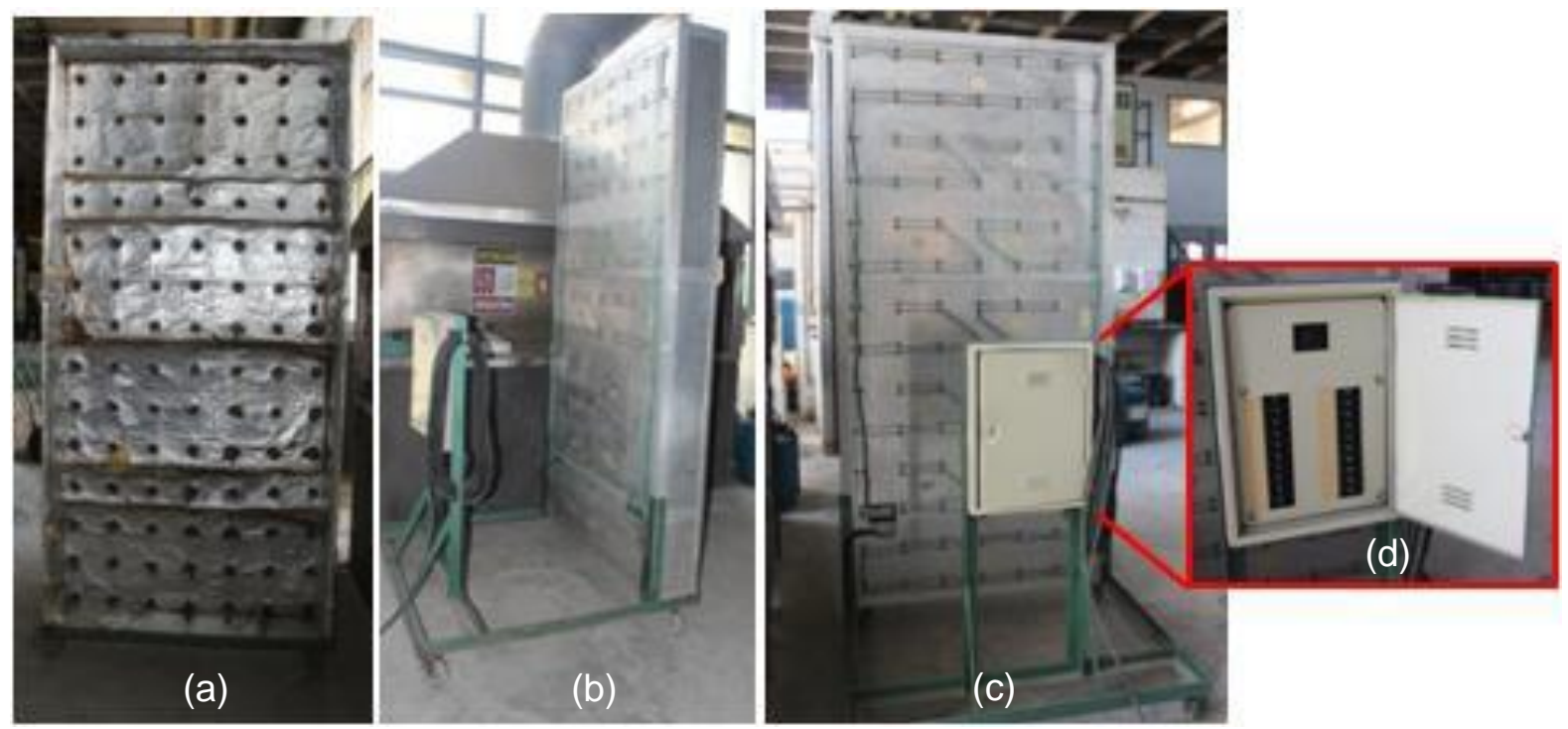

Figura 42. Detalhamento do painel térmico: (a) frente; (b) lateral; (c) fundo; (d) quadro de energia. (Fonte: Elaborado pelo autor).

Conforme ilustrado na Figura 43-a, a região do painel térmico efetivamente utilizada fica limitada à área do pórtico. Com potência total de 7350 Watts ou $4083 \mathrm{~W} / \mathrm{m}^{2}$, posicionado a uma distância média de $25 \mathrm{~cm}$ da superfície a ser aquecida por incidência direta (Figura 43-b) proporcionou uma temperatura superficial entre $60^{\circ} \mathrm{C} \mathrm{e}$ $70^{\circ} \mathrm{C}$, em um tempo de exposição de 16 a 20 minutos para o substrato de bloco de concreto ou reboco e de 12 a 14 minutos para tijolo cerâmico ou revestimento cerâmico.

O menor tempo de aquecimento do revestimento cerâmico para chegar à mesma temperatura do reboco é devido à condutividade térmica mais elevada e maior capacidade de calor dos materiais cerâmicos em relação ao reboco e ao bloco de concreto.

Apesar do aquecimento forçado ser maior que a incidência de radiação solar sobre uma fachada de edifício, o pulso de energia mais intenso dá melhores resultados no tempo mais curto.

Em cada ensaio o painel térmico ficou posicionado de forma a promover o aquecimento de toda a parede. Em ambos os casos, as laterais (Figura 44-a) e parte superior dos painéis (Figura 44-b) foram isolados com placas de drywall, isopor e/ou papelão para garantir o direcionamento do calor à área desejada. 
Para a etapa de campo, a fonte de radiação utilizada foi o sol, situação igual à vivenciada pelas fachadas dos edifícios para que os comportamentos fossem estudados em condições reais.

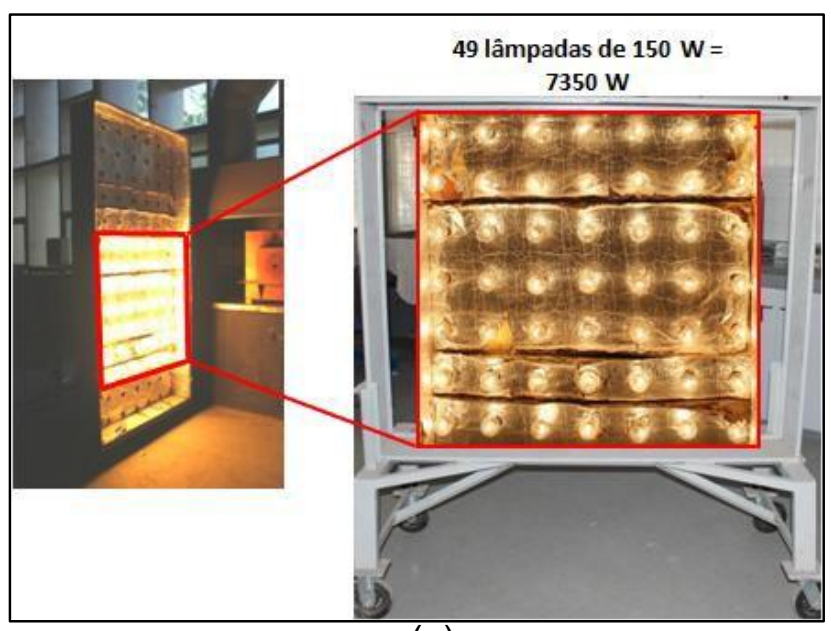

(a)

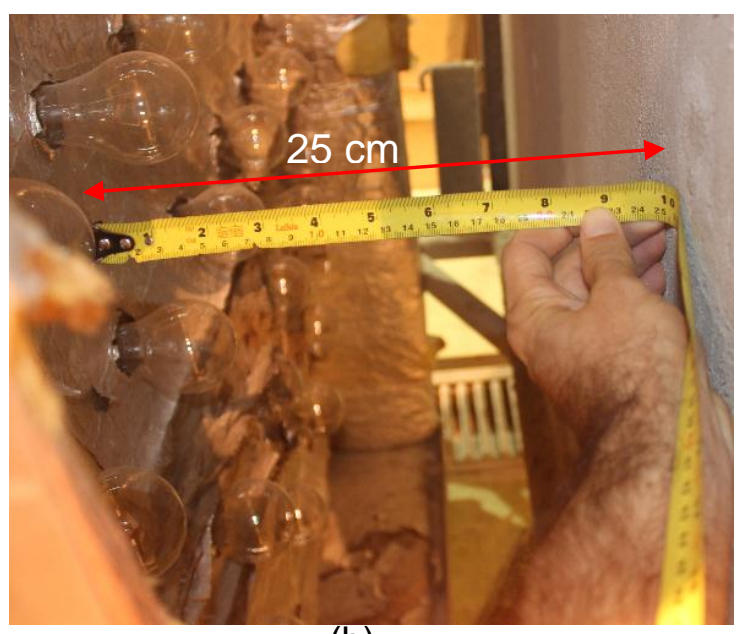

(b)

Figura 43. (a) Área de uso do painel térmico; (b) Distância entre painel e superfície dos painéis. (Fonte: Elaborado pelo autor).

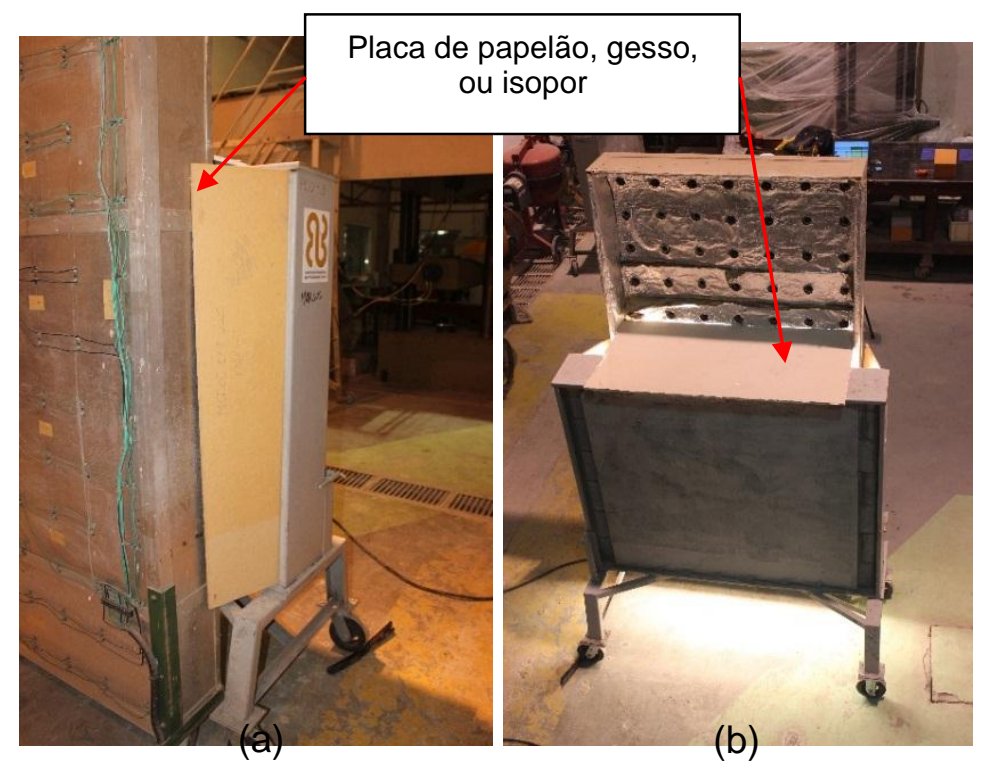

Figura 44. (a) Detalhe do isolamento lateral do painel térmico; (b) Detalhamento da posição do painel térmico em relação às paredes e isolamento térmico superior. (Fonte: Elaborado pelo autor).

- Painel de resfriamento

$\mathrm{Na}$ identificação de umidade através da termografia de infravermelho, o resfriamento evaporativo na área úmida, a diminuição da resistência térmica e o aumento da 
capacidade de armazenamento de calor do material úmido (ASTM C1153-10, 2010), normalmente conduzem à criação de variações de temperatura na superfície em observação fundamental para a identificação dos defeitos (ROSINA; LUDWIG, 1999).

O resfriamento foi feito de forma natural por exposição à temperatura ambiente em todas as etapas e também forçada, unicamente na etapa de laboratório, através do uso de um painel de resfriamento (Figura 45-a) estruturado por um pórtico de madeira contendo uma rede de mangueiras e bicos de aspersão que pulveriza água, conforme ilustrado na Figura 45-b. A alimentação de água é feita por uma torneira (Figura 45-c) que proporciona uma vazão constante de água.
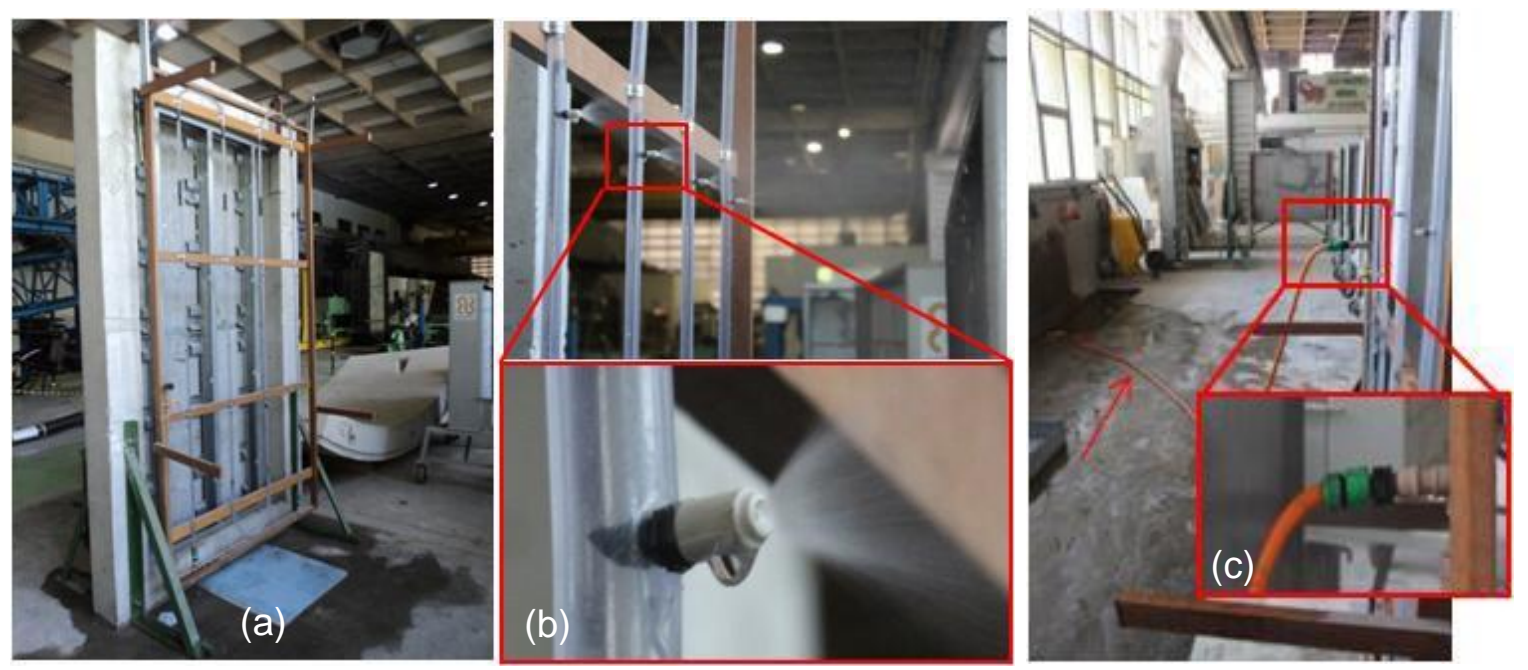

Figura 45. (a) Painel de resfriamento; (b) Detalhamento do bico aspersor de água; (c) Detalhamento da alimentação de água do painel de resfriamento. (Fonte: Elaborado pelo autor).

As paredes ficaram sempre posicionadas à mesma distância de $37,5 \mathrm{~cm}$ do painel de resfriamento (Figura 46-a) através de hastes de madeira fixadas nas duas laterais, conforme destacado na Figura 46-b. 


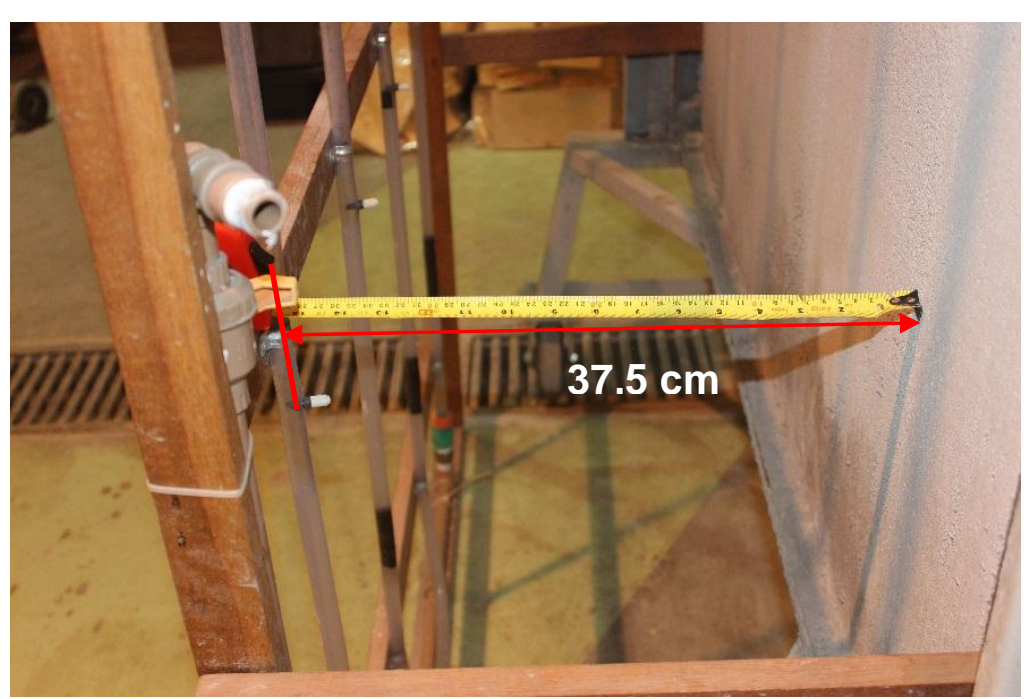

(a)

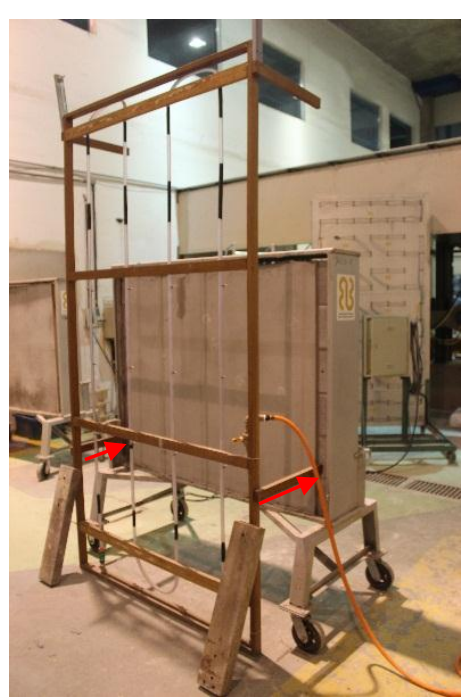

(b)

Figura 46. (a) Detalhe da haste de madeira que mantém as paredes a uma distância fixa do painel de resfriamento; (b) Visão do conjunto painel PCO2 e painel de resfriamento. (Fonte:

Elaborado pelo autor).

\subsubsection{Experimento realizado}

\subsubsection{Planejamento de ensaios: etapas de laboratório e campo}

Para cada face dos painéis foram estabelecidos os tipos de análises a serem realizadas através dos termogramas para identificação de defeitos na condição de diferenças de temperatura entre a região com defeito e seu entorno:

- PCE1-A (Figura 47-a): revestimento de argamassa na condição sem defeitos.

$>$ diferenciar as juntas de assentamento de alvenaria dos blocos de concreto ou tijolo cerâmico sob o reboco.

- PCE1-B (Figura 47-b): alvenaria na condição sem defeitos e com defeitos reais de fissuras (em vermelho) na argamassa de assentamento dos tijolos cerâmicos (face não revestida com reboco).

identificar fissuras de até $0,5 \mathrm{~mm}$ e fissuras inferiores a $1,0 \mathrm{~mm}$ na argamassa de assentamento. 


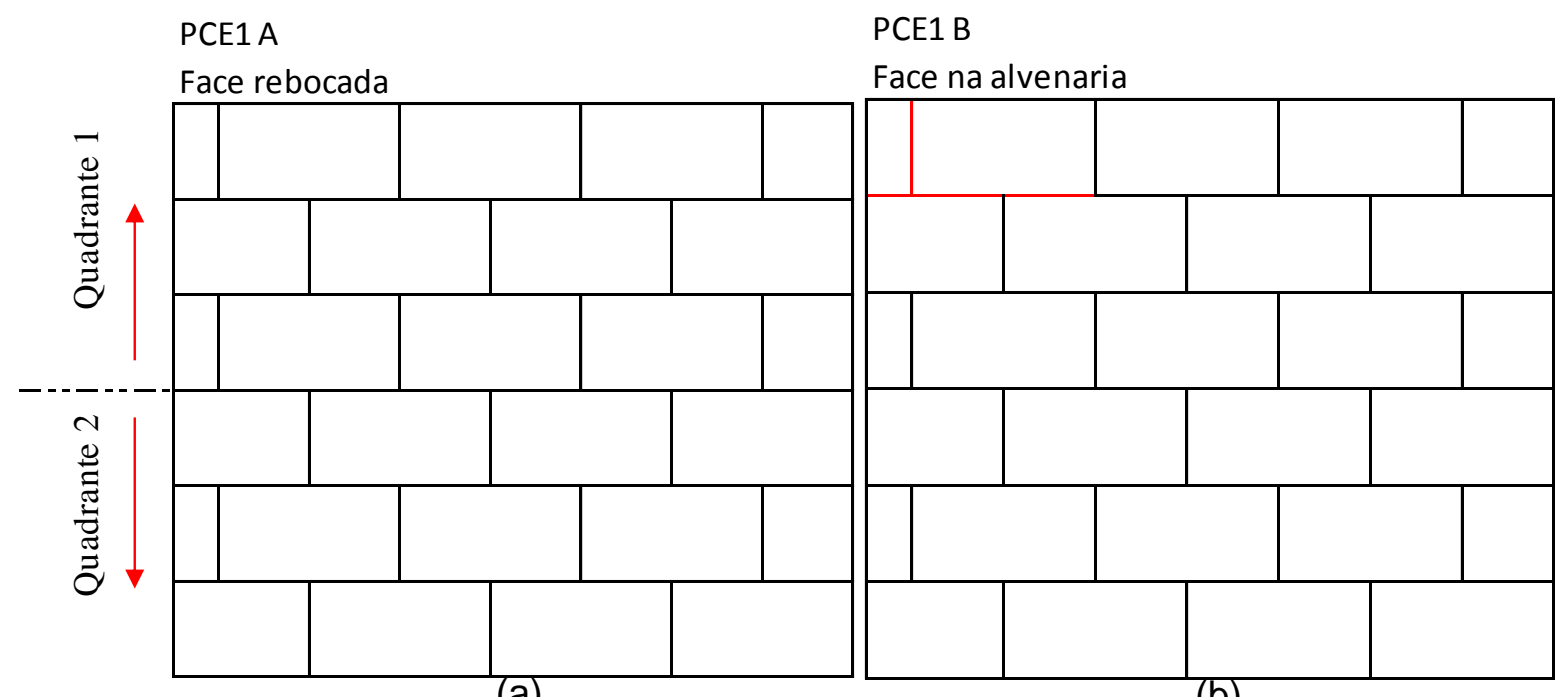

(a)

(b)

Figura 47. (a) Ilustração do painel PCE1-A sem defeitos; (b) llustração do painel PCE1-B com a localização de defeitos de fissuras na argamassa de assentamento de alvenaria (linhas vermelhas). (Fonte: Elaborado pelo autor).

- PCO1-A (Figura 48-a): revestimento de reboco na condição de defeito simulando descolamento de reboco (azul) e alvenaria com ausência de argamassa de assentamento nas juntas verticais da alvenaria (em vermelho):

diferenciar as juntas verticais da alvenaria com e sem argamassa de assentamento sob o reboco.

> identificar junta de assentamento de alvenaria sem argamassa sob descolamento na interface alvenaria/reboco.

- PCO1 B (Figura 48-b): alvenaria na condição de ausência de argamassa de assentamento nas juntas verticais (em vermelho).

diferenciar as juntas verticais da alvenaria com e sem ausência de argamassa de assentamento. 


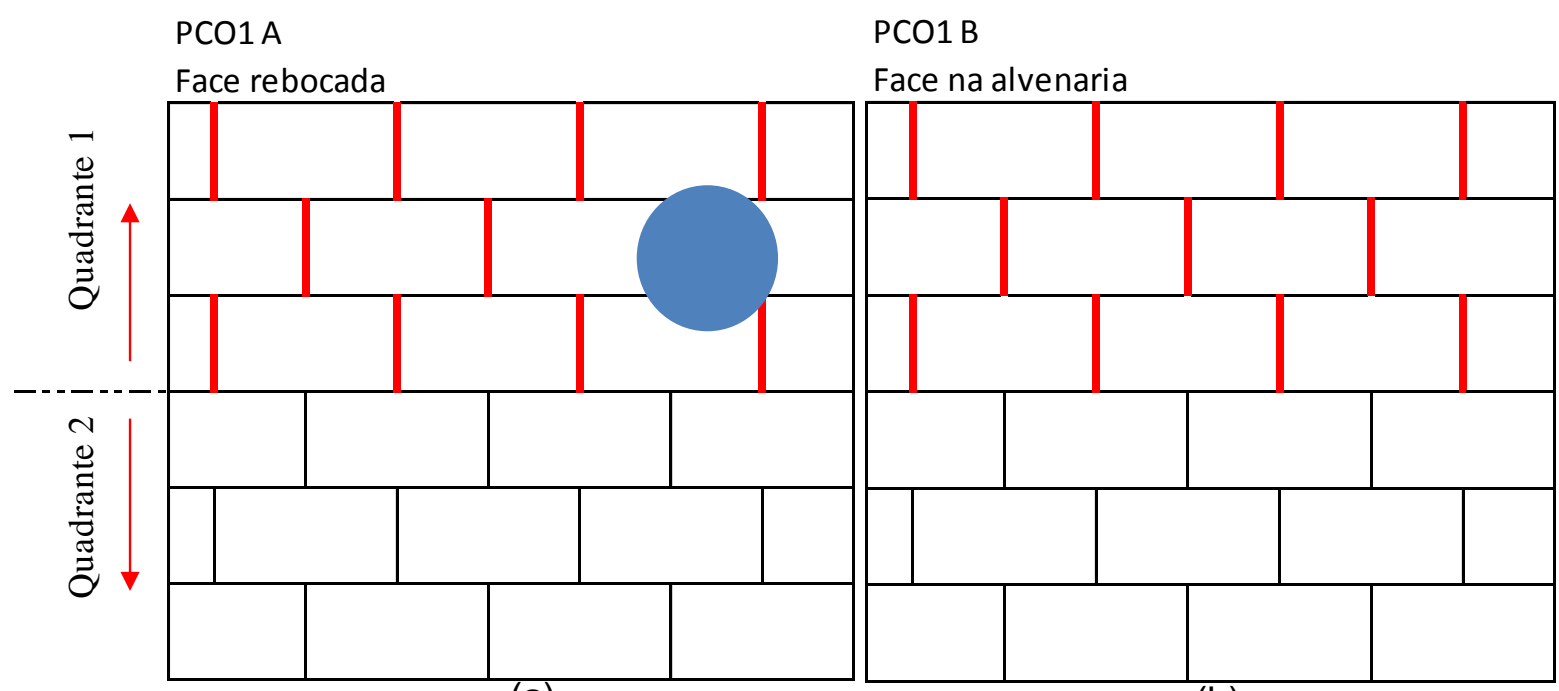

(a)

(b)

Figura 48. (a) Ilustração do painel PCO1-A com a localização das juntas verticais de assentamento da alvenaria sem argamassa e do defeito de descolamento (isopor); (b) llustração do painel PCO1-B com a localização das juntas verticais de assentamento da alvenaria sem argamassa. (Fonte: Elaborado pelo autor).

- PCE 2 (Figura 49) e PCO 2 (Figura 50) - Faces A e B: revestimento de reboco na condição de defeitos e não defeitos de descolamento (Figura 49 e Figura $50)$.

identificar fissuras de 0,5 $\mathrm{mm}$ e trincas de até $1,0 \mathrm{~mm}$ na superfície do reboco.

identificar defeitos de descolamento na interface alvenaria/reboco quanto à dimensão, à forma, à espessura e ao tipo de material que compõe o defeito. 


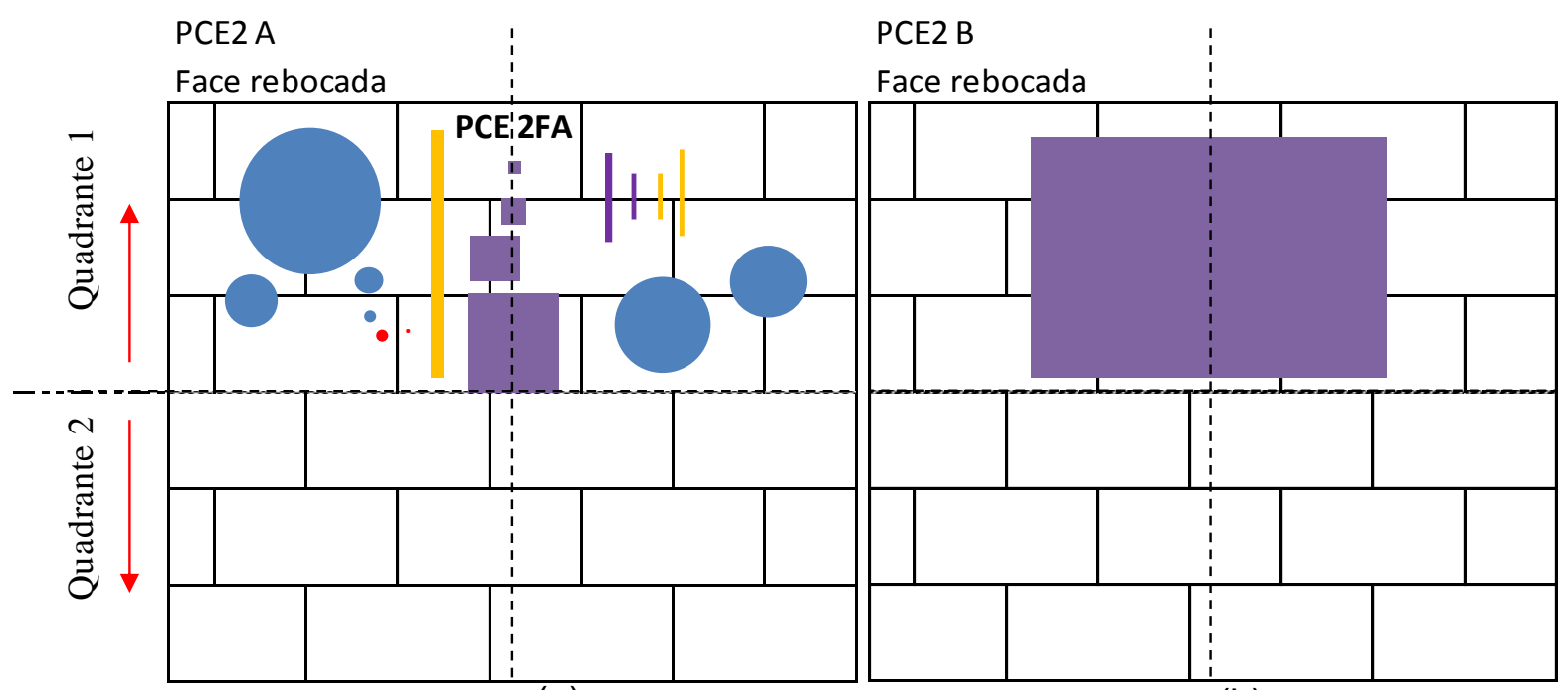

(a)

(b)

Figura 49. Ilustração com a localização dos defeitos de descolamento na interface alvenaria/reboco no painel: (a) PCE2-A; (b) PCE2-B. (Fonte: Elaborado pelo autor).

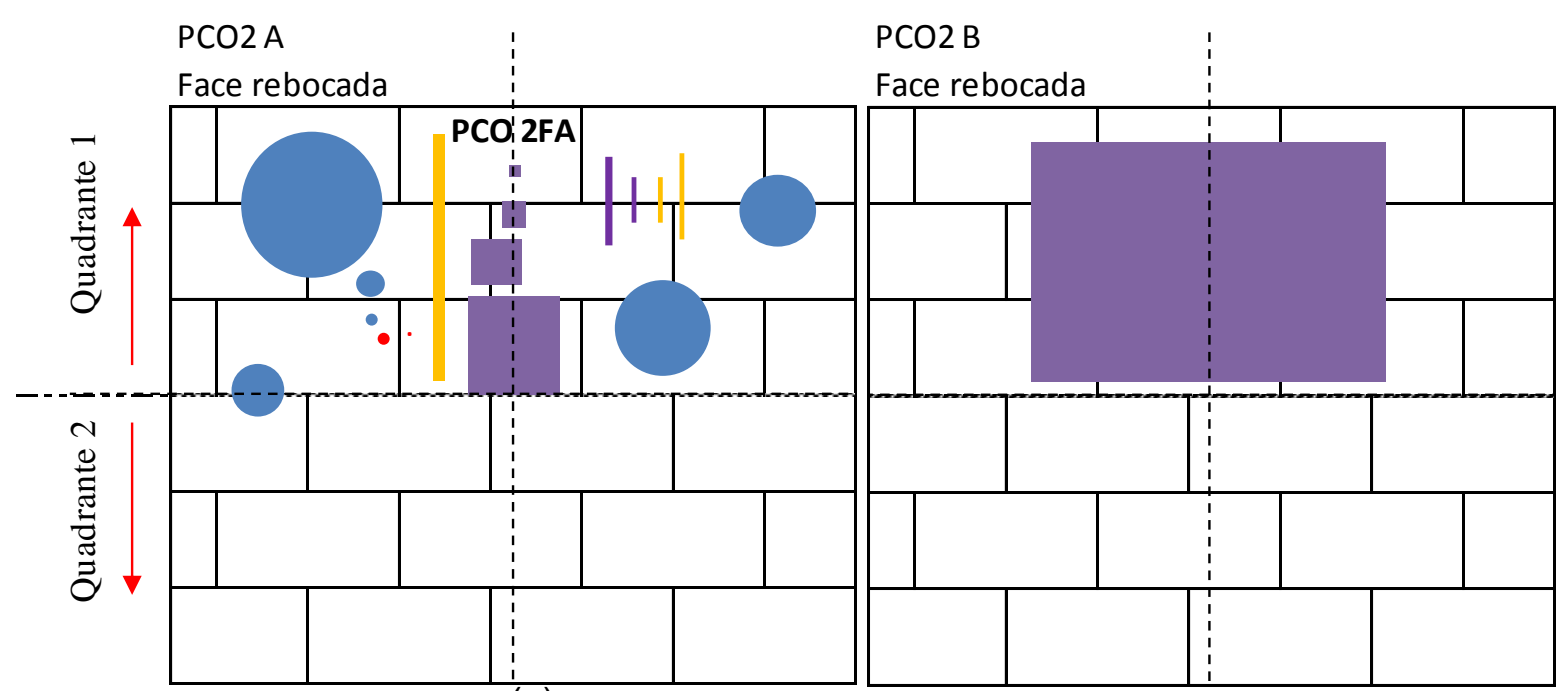

(a)

(b)

Figura 50. Ilustração com a localização dos defeitos de descolamento na interface alvenaria / reboco no painel: (a) PCO2-A; (b) PCO2-B. (Fonte: Elaborado pelo autor).

- PCE3 B e PCO3 A (Figura 51-a e Figura 51-b respectivamente): revestimento cerâmico na condição de defeitos e não defeitos de descolamento.

$>$ identificar descolamento na interface reboco/revestimento cerâmico quanto à dimensão e à forma que compõem o defeito. 

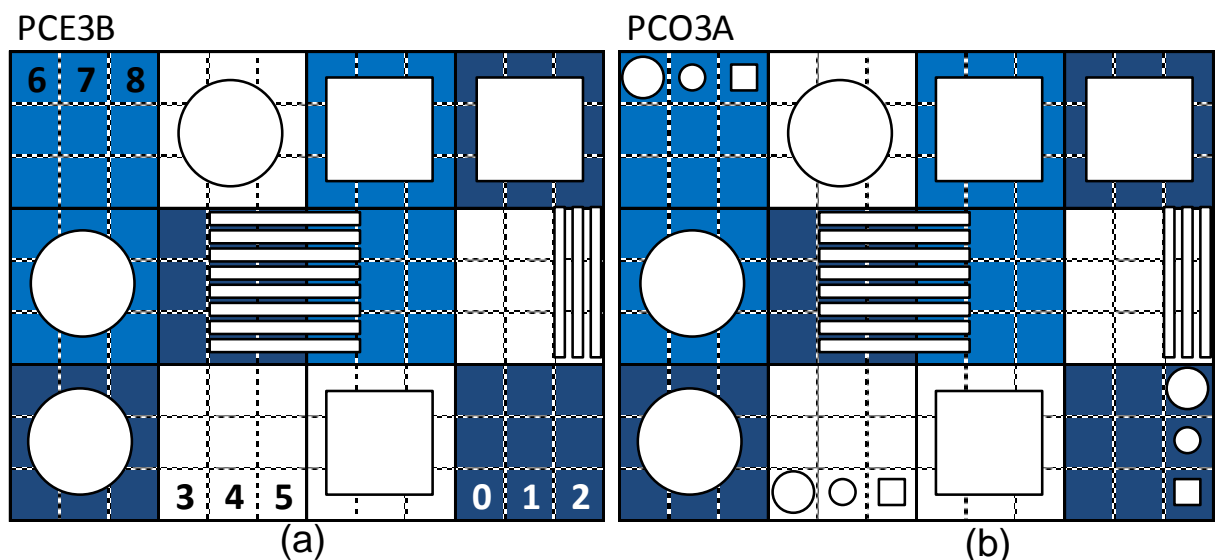

(b)

Figura 51. Ilustração com a localização dos defeitos de descolamento na interface reboco / cerâmica no painel: (a) PCE3-B; (b) PCO3-A. (Fonte: Elaborado pelo autor).

- PCE3 A e PCO3 B: revestimento cerâmico na condição de falhas de assentamento (vazios de argamassa).

identificar falhas executivas de assentamento de revestimento cerâmico (Figura 52-a e Figura 52-b: apenas cerâmicas com a marcação "x" possuem argamassa colante no verso).

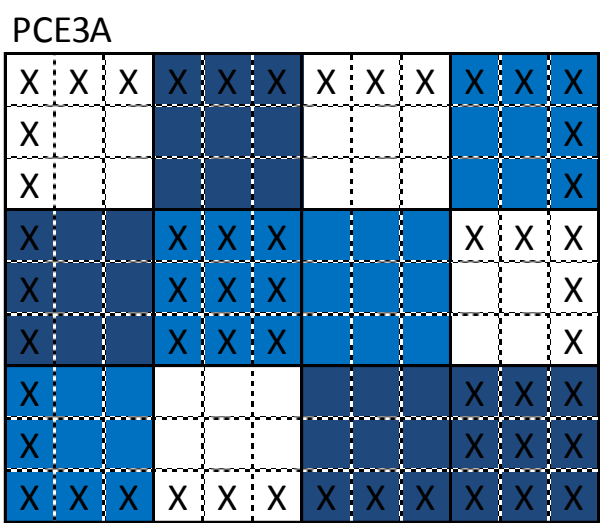

(a)

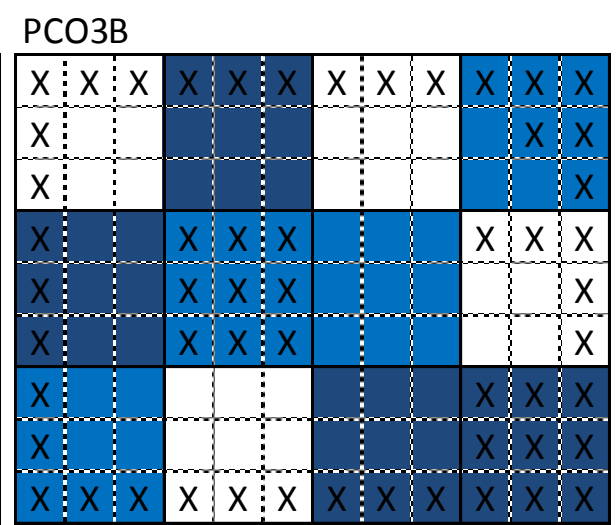

(b)

Figura 52. Ilustração com a localização dos defeitos de vazios de argamassa (quadros s/ a marcação "X") na interface reboco/cerâmica no painel: (a) PCE3-A; (b) PCO3-B. (Fonte: Elaborado pelo autor).

- PCE3-A e PCO3-B: revestimento cerâmico na condição de falhas de assentamento (vazios de argamassa) e reboco na condição de defeitos de descolamento.

> identificar sobreposição de defeitos de descolamento do revestimento de reboco com vazios de argamassa no assentamento de revestimento cerâmico (Figura 53-a e Figura 53-b). 


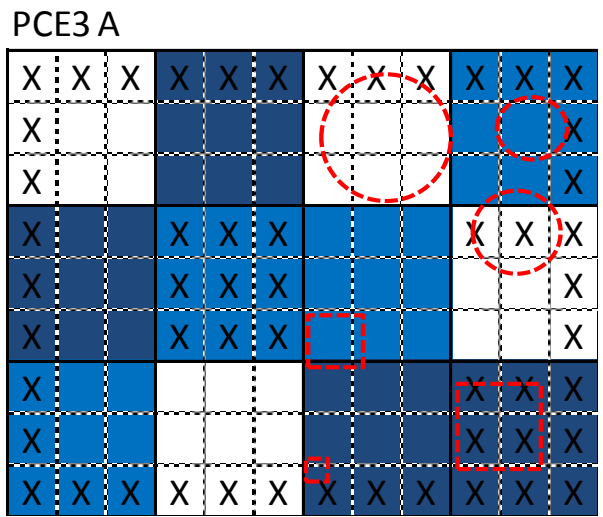

(a)

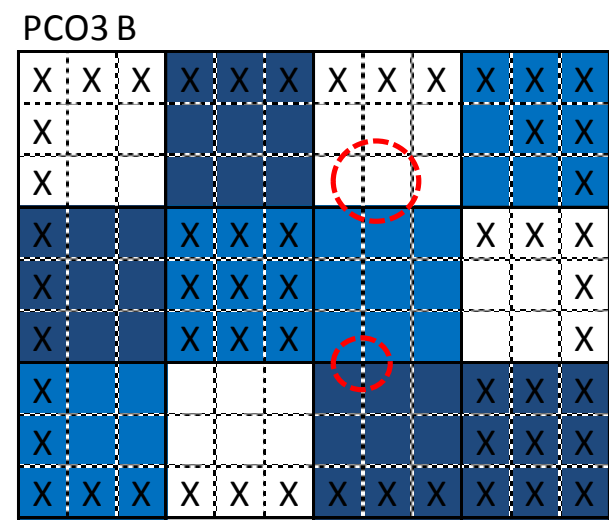

(b)

Figura 53. Esquema ilustrativo de sobreposição de defeitos de descolamentos sob o reboco (linhas vermelhas pontilhadas) e descolamentos de cerâmica (quadros sem a marcação "X") no painel: (a) PCE3-A; (b) PCO3-B. (Fonte: Elaborado pelo autor).

- PCE3-B e PCO3-A: revestimento cerâmico e reboco na condição de defeitos de descolamento

identificar sobreposição de defeitos de descolamento do reboco e do revestimento cerâmico (Figura 54-a e Figura 54-b).

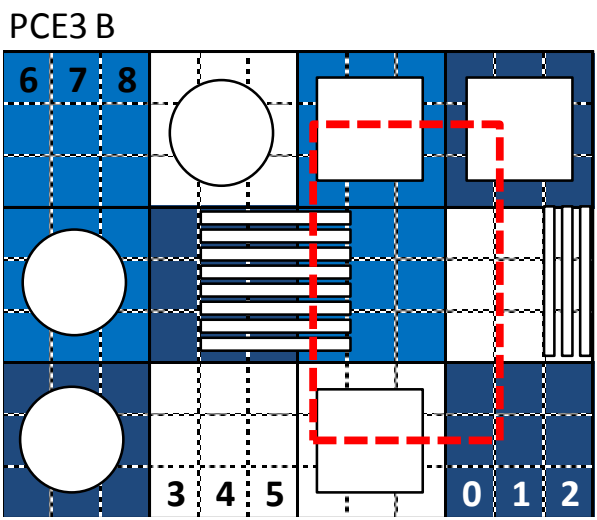

(a)

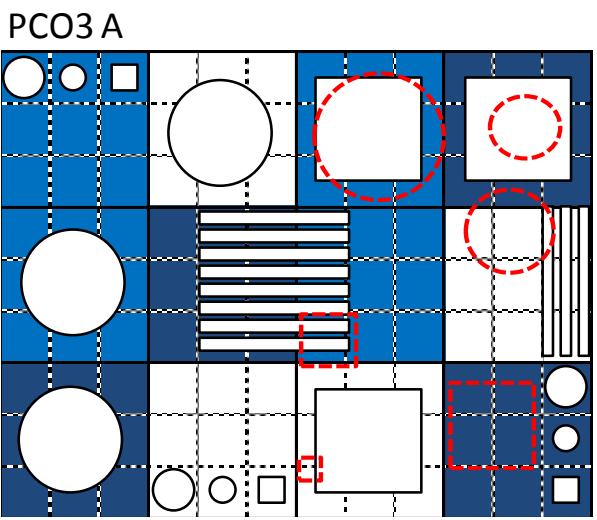

(b)

Figura 54. Esquema ilustrativo de sobreposição de defeitos de descolamento sob o reboco (linhas vermelhas pontilhadas) e vazios sob o revestimento cerâmico (figuras delimitadas por linhas pretas e números) no painel: (a) PCE3-B; (b) PCO3-A. (Fonte: Elaborado pelo autor).

\subsubsection{Planejamento de ensaios: in situ}

Para as fachadas estudadas in situ foram estabelecidos os tipos de análises a serem realizadas através dos termogramas para identificação de defeitos na condição de uso da tecnologia em ambiente aberto, sob a incidência direta de sol para aquecimento e resfriamento natural gerando as diferenças de temperatura entre a região com defeito e seu entorno. 
Tipos de análise:

- verificar por intermédio de um estudo de caso a capacidade de a termografia identificar defeitos de descolamento de revestimentos cerâmicos ocultos na fachada, comparativamente à técnica de mapeamento por "percussão";

- identificar fissuras não visíveis a olho nu no revestimento de argamassa em fachada;

- como ferramenta de controle de execução/recuperação de defeitos de desplacamento em revestimento cerâmico de fachada;

- identificar influências intrínsecas ao processo de uso da tecnologia em ambiente aberto na visualização dos defeitos;

- levantar as influências do uso de recursos do equipamento e do software na visualização dos defeitos.

\subsubsection{Rotina de ensaios}

Antes dos ensaios, foi realizada a calibração/ajuste da câmera térmica para se ter uma apresentação adequada do objeto de estudo ou composição e assim garantir a assertividade dos dados e a qualidade das informações coletadas através dos termogramas. No caso da câmera T650, utilizada em todas as etapas, os ajustes são:

- valor de emissividade do substrato

- temperatura refletida pelo substrato

- distância entre a câmera e o substrato

- umidade relativa

- temperatura ambiente

- amplitude térmica

- foco térmico (nível e contraste)

- intervalo de tempo entre cada termograma

$\mathrm{Na}$ etapa de laboratório a rotina dos ensaios foi composta pelos seguintes passos:

- posicionar os painéis em relação à câmera térmica a uma distância de $323 \mathrm{~cm}$ (Figura 55-a), distância mínima necessária para que o campo de visão térmico do equipamento fique dentro dos limites internos do pórtico metálico (Figura 
55-b), de forma que apenas sejam capturadas informações do substrato em análise (alvenaria, argamassa de revestimento e cerâmica).

a câmera térmica foi acoplada a um tripé para garantir agilidade aos ensaios, uma vez que, fixado o posicionamento do tripé, apenas os painéis se movimentassem.

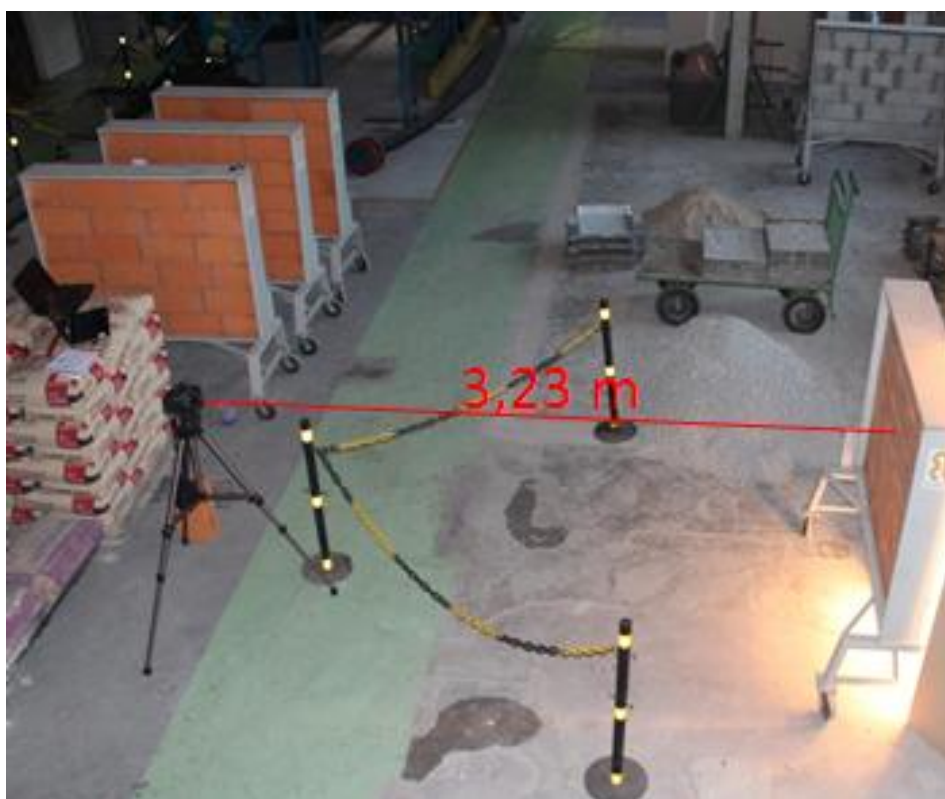

(a)

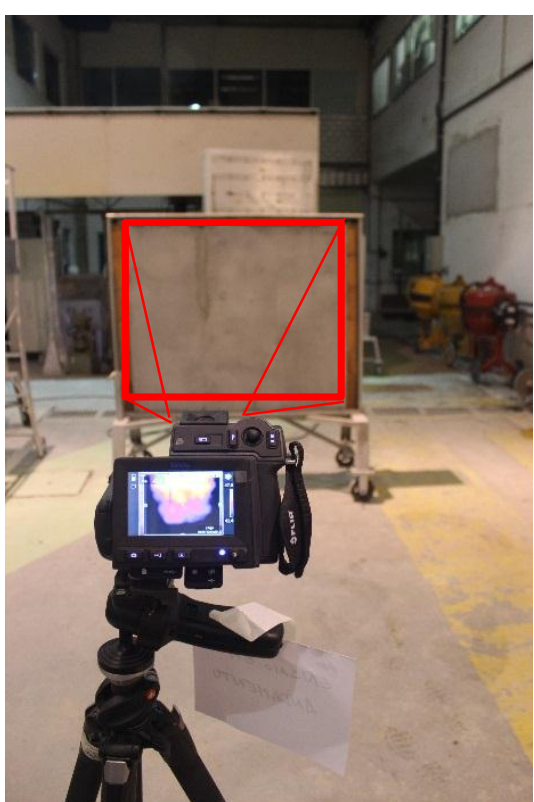

(b)

Figura 55. (a) Distância entre painel e câmera térmica; (b) Enquadramento da imagem térmica nos limites internos do pórtico. (Fonte: Elaborado pelo autor).

os painéis, por sua vez, eram posicionados de acordo com referências fixas no piso, a fim de manterem também a distância estabelecida (Figura 56).

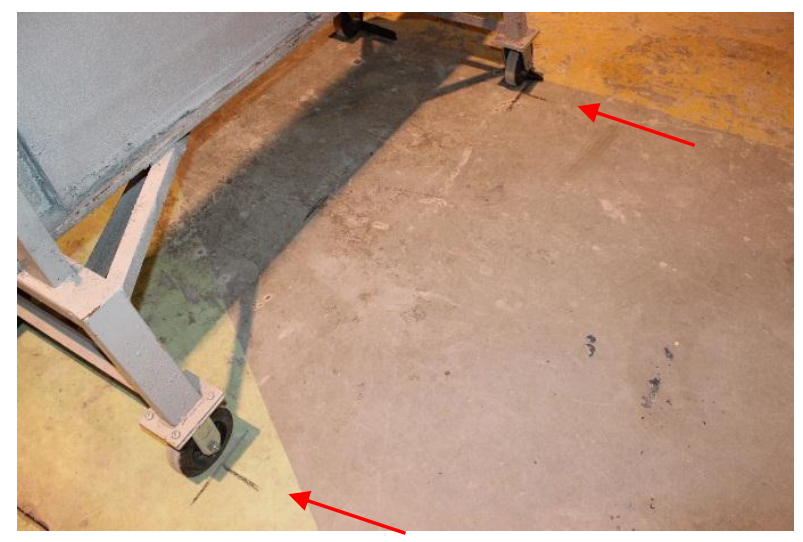

Figura 56. Referencias no piso do laboratório para posicionamento dos painéis. (Fonte: Elaborado pelo autor). 
- medir e registrar a temperatura e a umidade ambiente e a temperatura do substrato (Figura 57 ).

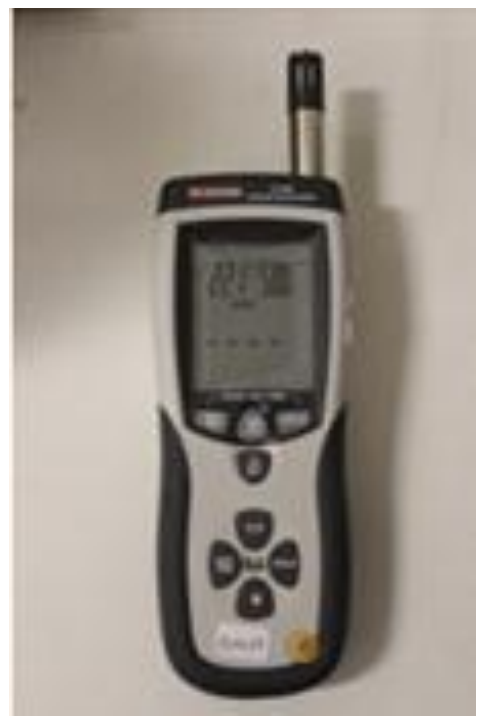

Figura 57. Medição de temperatura e umidade ambiente. (Fonte: Elaborado pelo autor).

- registrar um termograma da superfície do substrato mais próxima possível do equilíbrio térmico com o ambiente (laboratório) antes do aquecimento forçado com uso do painel térmico;

- posicionar o painel térmico a uma distância de aproximadamente $25 \mathrm{~cm}$ da superfície a ser aquecida;

- isolar as laterais e a parte superior do painel térmico com placas de drywall, isopor e/ou papelão para garantir o direcionamento do calor à área desejada;

- acionar o painel para exposição da superfície à incidência direta de radiação térmica até atingir a faixa de temperatura superficial entre $60^{\circ} \mathrm{C}$ e $70^{\circ} \mathrm{C}$ similares à de uma fachada sob a incidência direta de sol (aproximadamente 65으 $\mathrm{C}$ em fachadas);

tempo de exposição entre 16 e 20 minutos para superfície de alvenaria e reboco.

tempo de exposição entre 12 a 14 minutos para superfície cerâmica. 
- acompanhar a temperatura da superfície em aquecimento, com leituras térmicas frequentes através de termômetro laser;

- desligar e remover o painel térmico e os isolamentos após atingir as temperaturas;

- iniciar a captura dos termogramas imediatamente após a remoção do painel térmico com intervalos de cinco minutos entre imagens até a estabilização térmica do painel em relação à temperatura ambiente;

- armazenar as imagens e registrar todos os dados na planilha de controle de ensaios.

Nos ensaios onde foi realizado o resfriamento forçado, antes do início da captura dos termogramas até a estabilização térmica do painel, são incluídas as seguintes etapas:

- registrar um termograma da superfície aquecida;

- posicionar o painel de resfriamento a uma distância de aproximadamente 50 cm da superfície a ser resfriada;

- acionar o painel para exposição do substrato à pulverização de água por cinco minutos (fixos);

- desligar e remover o painel de resfriamento.

Para os ensaios de campo, os passos de posicionamento dos painéis em relação à câmera, registrar a temperatura e umidade ambiente e temperatura do substrato seguiu os mesmos critérios da etapa de Laboratório. Imediatamente após o posicionamento do painel (Figura 58) foram cumpridos os seguintes passos:

- registrar os termogramas durante o período de aquecimento ao sol até o limite de identificação do defeito pelo equipamento;

- posicionar os painéis no laboratório para registro dos termogramas durante o resfriamento à sombra, também até o o limite de identificação do defeito pelo equipamento;

- armazenar as imagens e registrar todos os dados na planilha de controle de ensaios. 


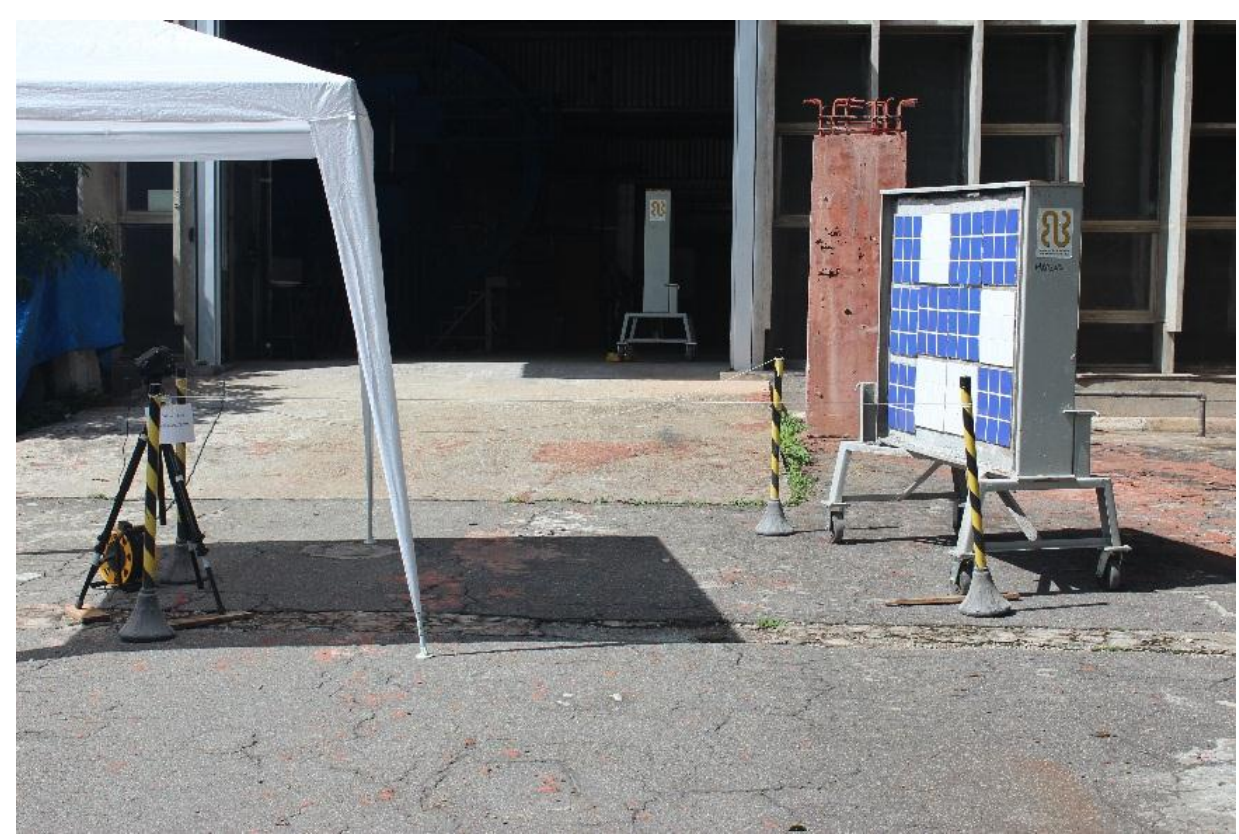

Figura 58. Posicionamento do painel na área externa do laboratório. (Fonte: Elaborado pelo autor).

Nas análises in situ a rotina de ensaios foi dividida em duas fases: uma composta pelos termogramas registrados manualmente a partir do pavimento térreo com a câmera T-650 e outra cujos registros foram realizados a partir de uma câmera térmica instalada em um drone (Figura 59), ambas compostas pelos seguintes passos:

- identificar o posicionamento do sol em relação às fachadas ao longo do dia;

- vistoriar visualmente a fachada para identificação dos defeitos visíveis a olho nu;

- calibrar/ajustar a câmera térmica;

- registrar os defeitos através dos termogramas.

$\mathrm{Na}$ fase com uso do drone acrescentam-se os seguintes passos:

- montar o drone e instalar a câmera térmica no gimbal (suporte de câmera);

- ligar câmera + drone e conectar com GPS. 


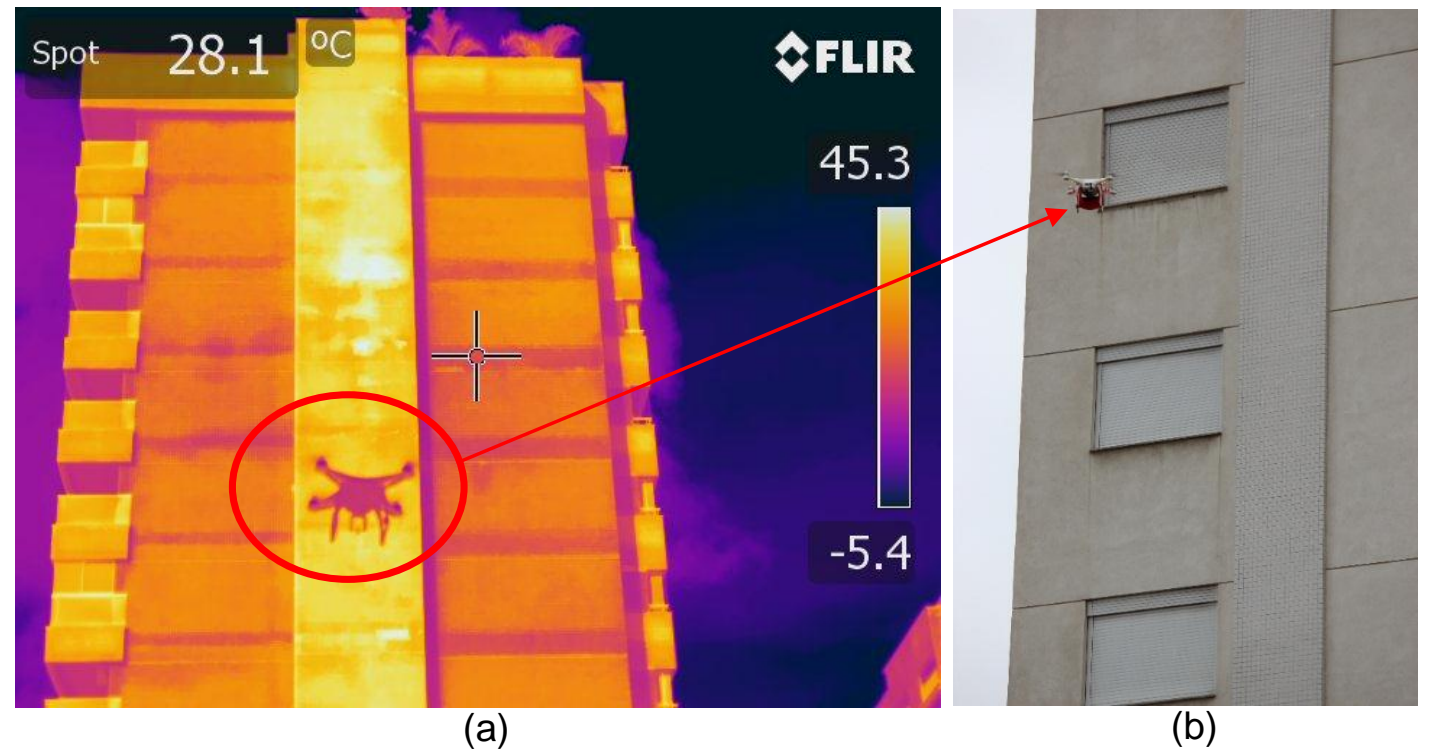

Figura 59. (a) Termograma do drone; (b) Imagem digital do drone. (Fonte: Elaborado pelo autor). 


\section{RESULTADOS}

\subsection{Escaneamento 3D laser aplicado à planicidade e volumetria de argamassa em fachada}

A partir do modelo escaneado (Figura 63) da fachada estudada foi feita uma série de análises e interpretações, considerando os itens:

- apresentação dos limites para uso do escaneamento 3D laser em obra;

- qualidade executiva do substrato, medido através do detalhamento da planicidade gerada pela imagem 3D;

- a influência do grau de nivelamento da estrutura na planicidade da alvenaria e na espessura da argamassa de revestimento;

- os impactos das áreas críticas mais externas da fachada (geradas pela falta de controle geométrico das estruturas) no consumo de argamassa com base na espessura de argamassa de revestimento necessária para regularizar o substrato e garantir o desempenho do sistema de revestimento;

- ganhos financeiros vs viabilidade econômica da técnica por causa da redução do consumo de argamassa pela análise volumétrica;

- possibilidades de uso da técnica em outras aplicações no canteiro de obras.

\subsubsection{Limites do uso do escaneamento em obra}

A viabilidade do uso do escaneamento 3D laser em obras passa por condições de contorno relacionadas ao projeto, além de práticas construtivas e características do canteiro. Sendo assim, o estudo permitiu identificar alguns limites para aplicação da técnica no canteiro de obras em razão das características de projeto e praticas construtivas adotadas usualmente. São elas:

- Condições para montagem e uso do equipamento na obra:

$>$ ponto de energia nos locais de leitura.

$>$ local plano de aproximadamente $2 \mathrm{~m}^{2}$ para montagem do equipamento (instalado sobre tripé).

$>$ combinação distância (afastamento) vs ângulo de leitura entre o equipamento e a fachada: 
- restrições para afastamento ou aproximação do equipamento em relação à edificação podem gerar ângulos de leitura acima de 85 graus que impossibilitem a varredura de toda a fachada com qualidade do modelo suficiente para análise (Figura 60-a).

- em edificações acima do raio limite de leitura, o escaneamento deverá ser realizado por um equipamento de maior capacidade ou em mais de um disparo, sendo o modelo posteriormente combinado com auxílio do software (Figura 60-b).

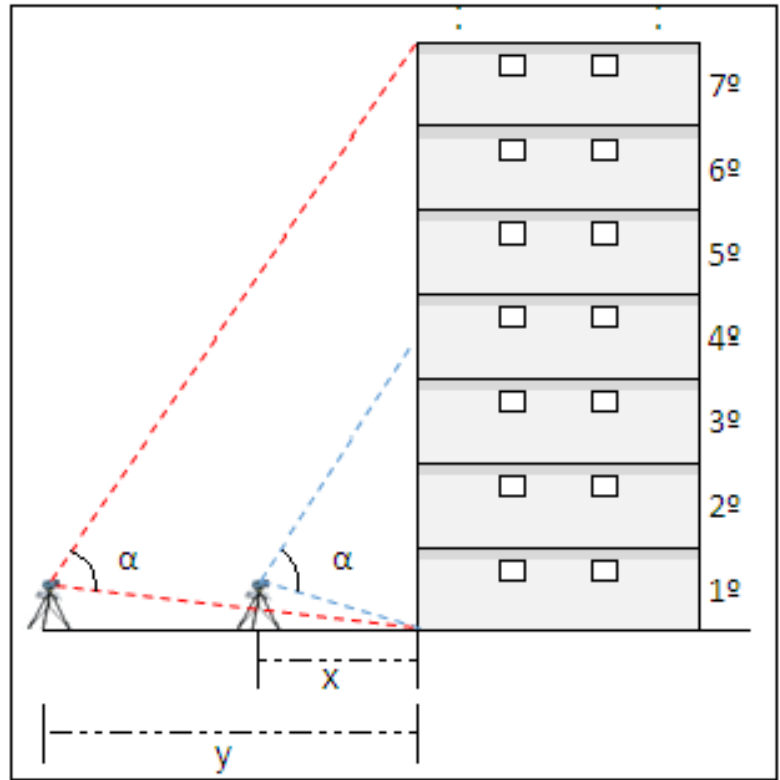

(a)

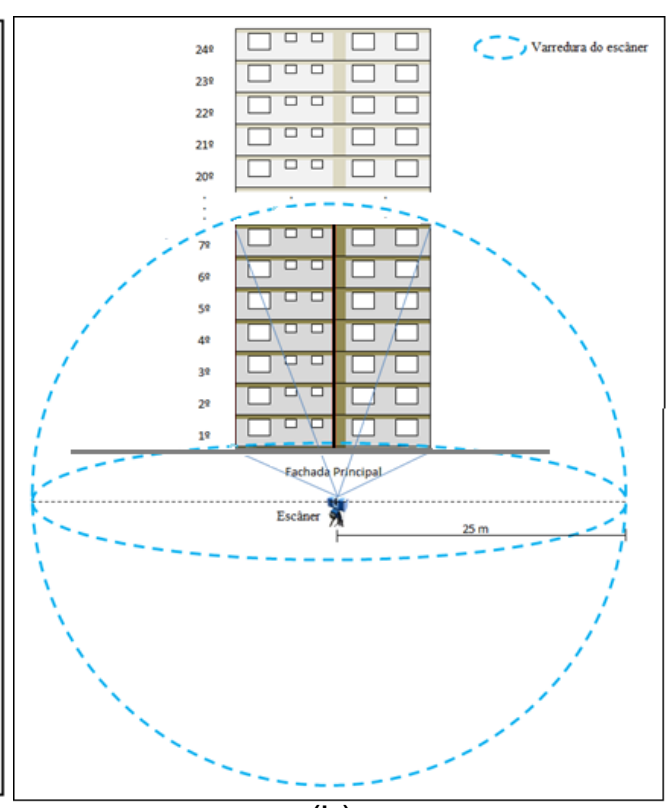

(b)

Figura 60. (a) Representação do afastamento do escâner em relação à fachada; (b) Representação da área de escaneamento da fachada em relação à capacidade do escâner e volume de varredura com 25 metros de raio (Fonte: Elaborado pelo autor).

- Condições para realização da leitura:

ausência de áreas de sombreamento, ou seja, áreas/pontos que, definida a localização do escâner e ângulo de leitura, geram obstrução (pontos cegos) entre o equipamento e a superfície a ser avaliada ocultando a leitura pelo escâner. São zonas de sombreamento:

- varandas e sacadas fora do plano principal da fachada e elementos decorativos.

- andaimes e telas fachadeiras, balancins, muros ou qualquer elemento/objeto localizado entre o escâner e a superfície de leitura. 
redução/eliminação das áreas de sombreamento dependendo da distância e/ou posição do escâner em relação à fachada (Figura 61):

- para viabilizar o posicionamento do escâner fora das zonas de sombreamento é necessário o uso de equipamentos, por exemplo, pranchas elevatórias (Figura 62-a) ou hastes (Figura 62-b) saindo da fachada. Esse procedimento aumenta a complexidade e o custo do serviço, sendo recomendado fazer uma análise de viabilidade, considerando o novo cenário.

redução/eliminação das áreas de sombreamento por meio da reconstrução de superfícies com o uso de softwares específicos:

- as técnicas de reconstrução de superfícies com o uso de softwares específicos não são efetivas, pois trabalham com modelos visuais que não são geometricamente precisos e não reconhecem explicitamente a identidade dos componentes ocultos, não capturando assim a imperfeição da fachada.

alinhamento com o cronograma da obra:

- para garantir o escaneamento integral da fachada sem ocasionar alterações na rotina do canteiro ou intervenções em etapas executivas, o alinhamento precisa ser executado no momento em que a etapa de alvenaria esteja finalizada e os andaimes/balancins e telas fachadeiras, necessários à execução do revestimento da fachada, ainda não estejam instalados. 


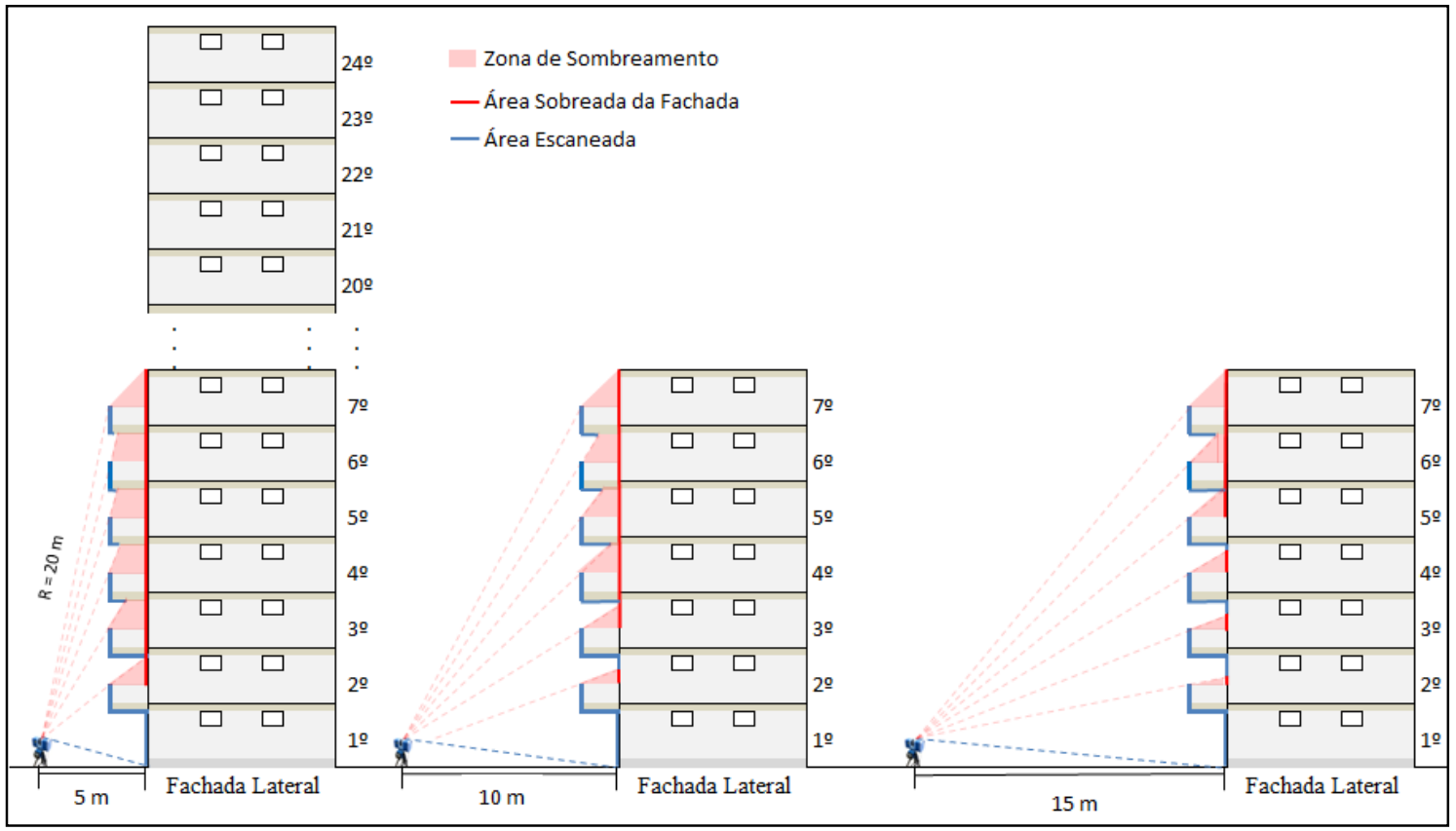

Figura 61. Redução da área de sombreamento da fachada em função da distância do escâner em relação à fachada do prédio (Fonte: Elaborado pelo autor).

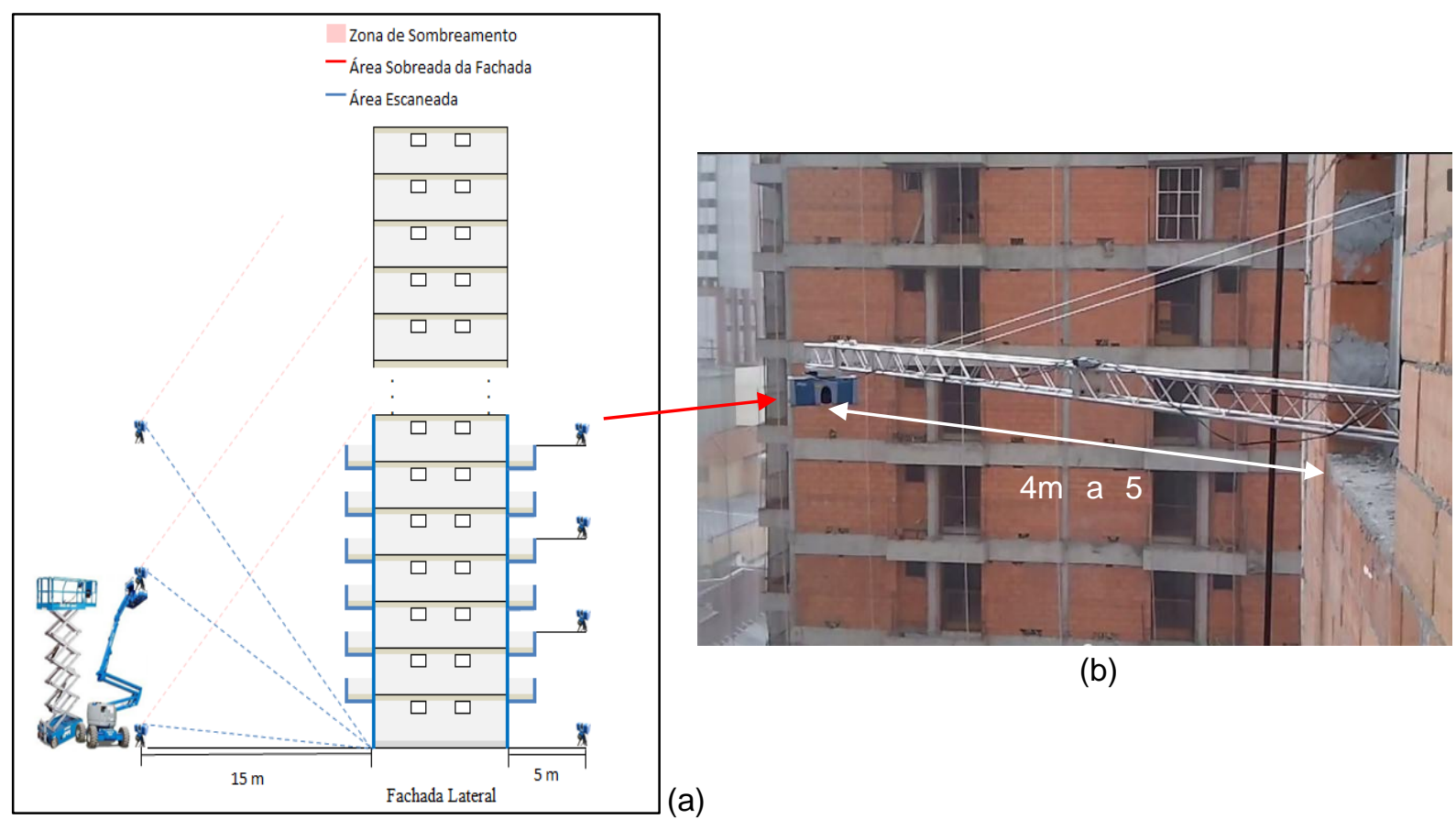

Figura 62. (a) Uso de pranchas elevatórias (Fonte: Elaborado pelo autor) e (b) hastes saindo para a fachada como recurso para reduzir as áreas de sombreamento (Fonte: T1 Engenharia Digital).

\subsubsection{Planicidade da fachada}

O escaneamento 3D laser fornece uma visão total do plano e, por meio do modelo gerado (Figura 63), sendo possível observar detalhes dos elementos que constituem 
a superfície, por exemplo, o posicionamento de cada bloco de concreto uns em relação aos outros e em relação à estrutura (vigas), além das condições de aplicação da argamassa de assentamento da alvenaria.

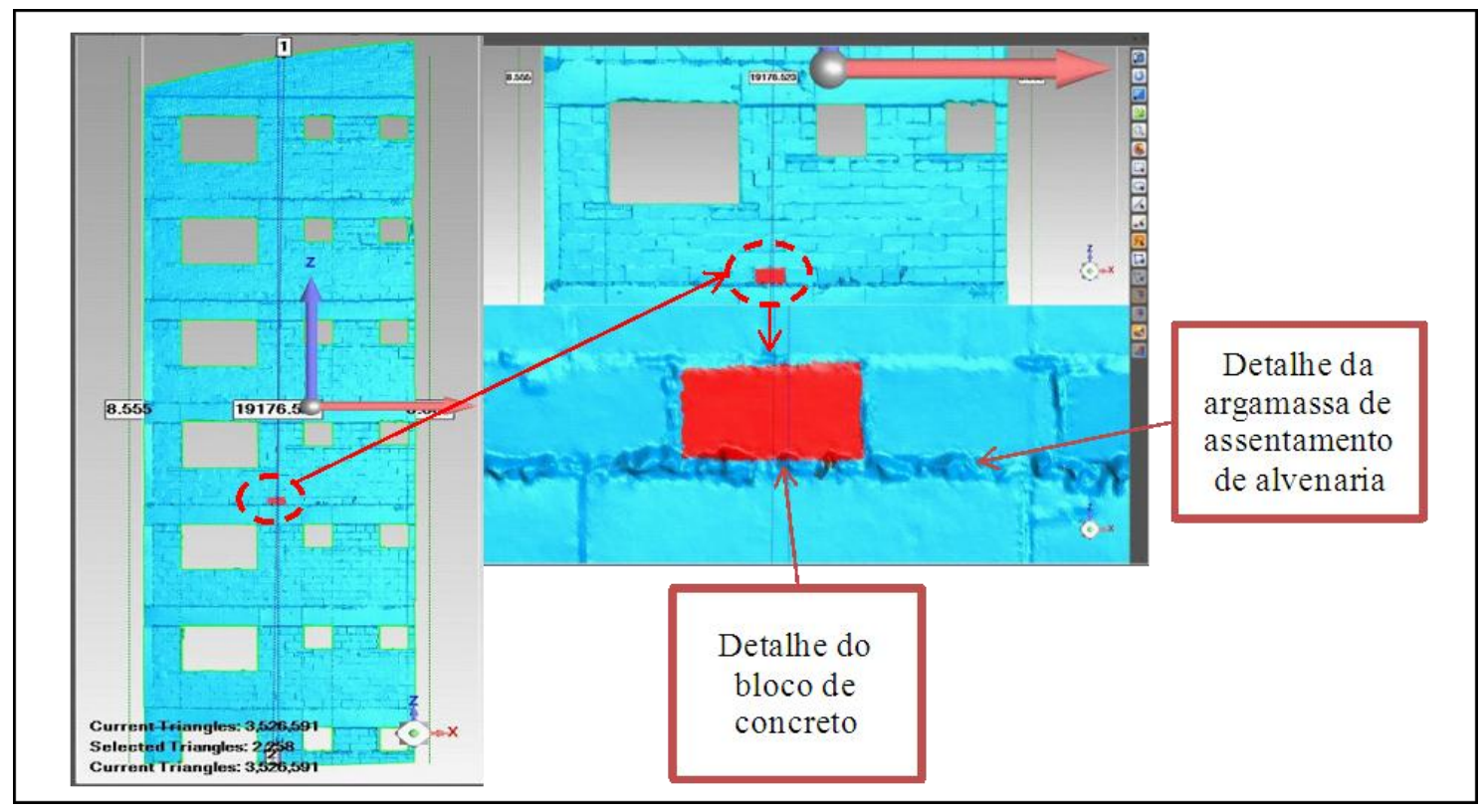

Figura 63. Imagem escaneada da fachada gerada pelo software. (Fonte: T1 Engenharia Digital)

\subsubsection{Refinamento em alinhamento e nivelamento da fachada}

Com a imagem do primeiro plano de referência (Figura 64-a) fica evidente o efeito da falta de controle geométrico das estruturas na planicidade da fachada, permitindo identificar em $100 \%$ da área escaneada os reais pontos críticos de irregularidade, e não apenas os pontos (seta vermelha na Figura 64-b) sob o fio de prumo (seta amarela na Figura 64-b).

Por meio de uma escala de cores quentes e frias e distância em milímetros (Figura 64-c), o software mostra respectivamente as regiões da fachada à frente (+) e atrás do plano (-). As áreas críticas à frente do plano normalmente estão localizadas sobre a estrutura e suas irregularidades influenciam o nivelamento e a planicidade da alvenaria, em geral posicionada atrás do plano, e ambas determinam a espessura final da argamassa de revestimento.

Essas colocações podem ser comprovadas na Figura 64-b por meio da interpretação da escala de cores/distâncias onde as áreas em tons esverdeados são aquelas mais próximas do plano de referência (eixo zero da escala): 
- as vigas 1,5 e 7, em tonalidade predominante amarela e/ou laranja, estão mais externas ao plano;

- a viga 1, com cor laranja escuro em boa parte da sua área, encontra-se no ponto mais externo da fachada;

- as vigas 2 e 4, na cor azul claro, encontram-se mais internas ao plano. o leve abaulamento no centro (área esverdeada), provavelmente foi causado por deformação da fôrma durante a concretagem.

- a viga 3 possui a área da direita para fora do plano (amarela) e a área da esquerda para dentro (azul), ou seja, encontra-se transversal ao plano;

- em menor grau, a viga 6 também encontra-se transversal ao plano, mas totalmente interna com diferentes tonalidades de azul;

- as regiões mais internas encontram-se sobre a alvenaria entre a $5^{\circ}$ e $7^{\circ}$ viga, área representada pela cor azul escura.

- observa-se um escalonamento de vigas em posição interna e externa. vigas ímpares mais externas e vigas pares mais internas;

- os pontos extremos (mais interno e mais externo) encontram-se a $57,8 \mathrm{~mm}$ atrás do plano de referência e 45,0 mm à frente, ou seja, variação de 102,8 $\mathrm{mm}$ entre o ponto mais interno e o mais externo do substrato.

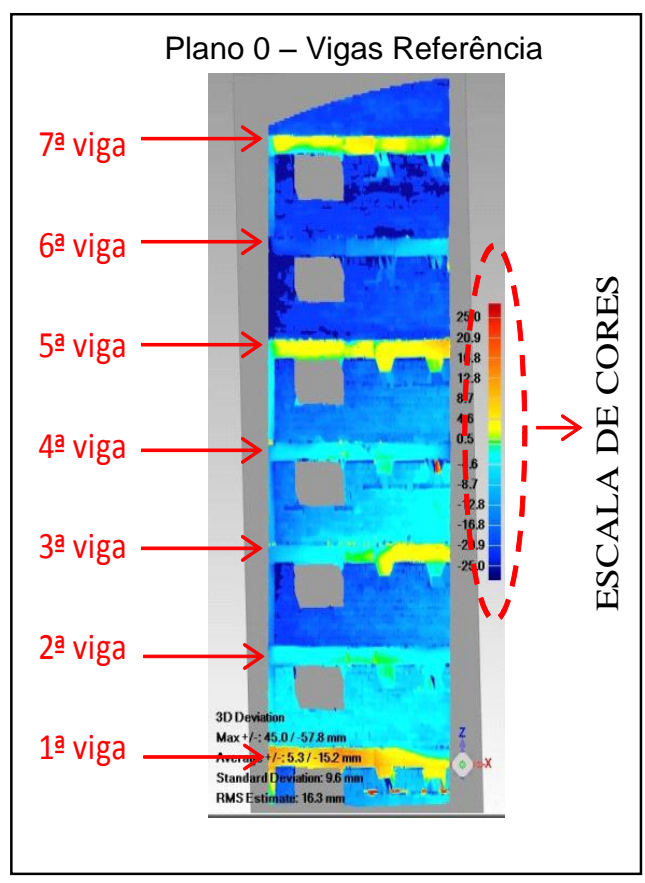

(a)

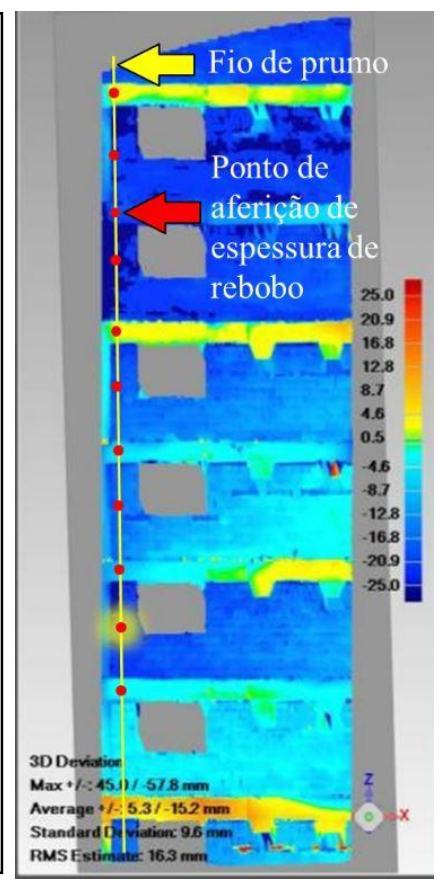

(b)

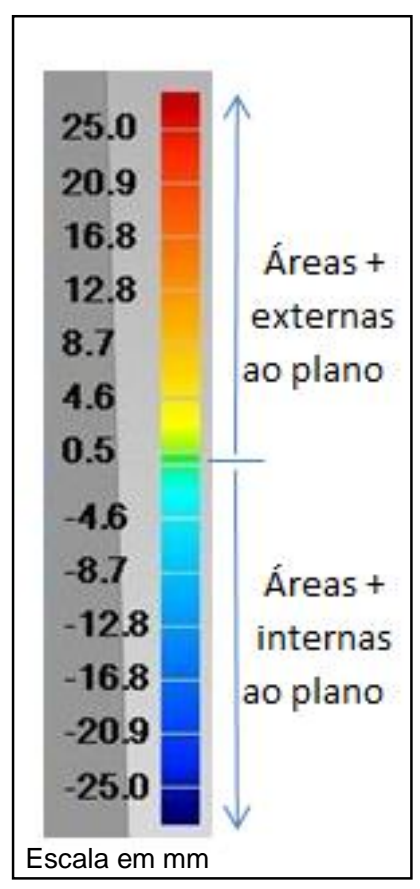

(c)

Figura 64. (a) Imagem do primeiro plano de referência gerado pelo software e identificação das vigas; (b) Pontos críticos de irregularidade em 100\% da área da fachada escaneada vs os pontos sob o fio de prumo; (c) Escala de cores. (Fonte: T1 Engenharia Digital). 
Os demais planos traçados, simulando diferentes espessuras de argamassa (Figura 65), permitiram medir a distância de cada ponto dos planos até a superfície da fachada escaneada. Com o uso do software, foram geradas as informações consolidadas na Tabela 7, em que as análises desses dados mostram que:

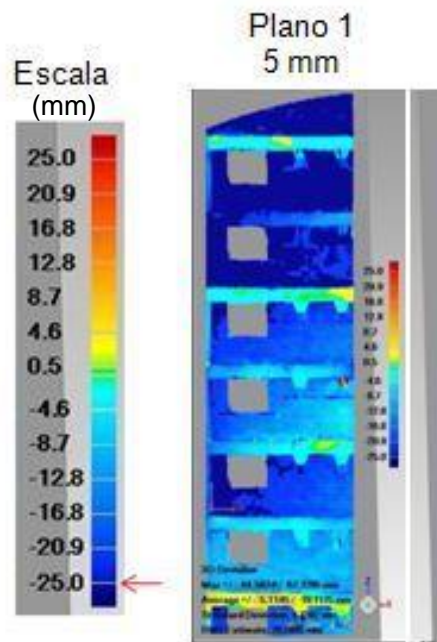

(a)

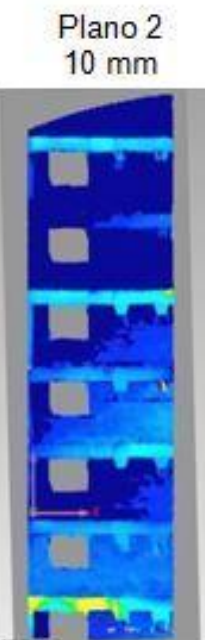

(b)

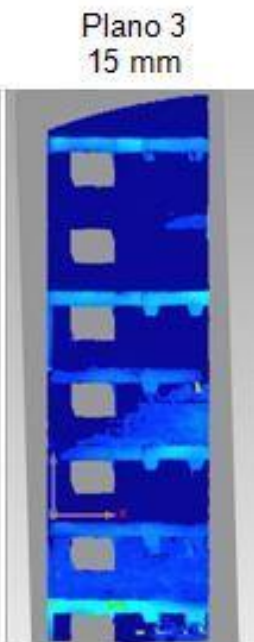

(c)

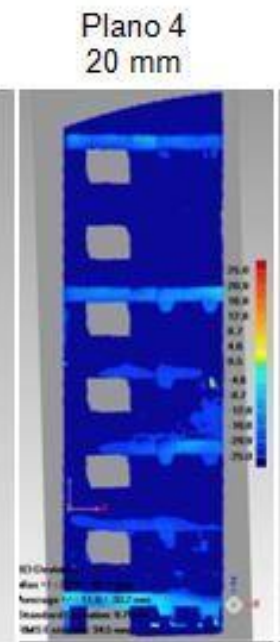

(d)

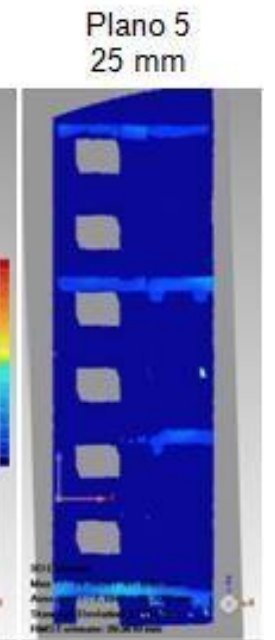

(e)

Figura 65. Imagem dos planos paralelos ao $1^{\circ}$ plano de referência a uma distância de: (a) 5 mm; (b) $10 \mathrm{~mm}$; (c) $15 \mathrm{~mm}$; (d) 20 mm; (e) $25 \mathrm{~mm}$ (Fonte: T1 Engenharia Digital).

Tabela 7. Resumo de resultados dos planos traçados a partir do $1^{\circ}$ plano de referência em relação à imagem escaneada. (Fonte: Elaborado pelo autor).

\begin{tabular}{|c|c|c|c|c|c|}
\hline & \multirow[b]{3}{*}{ Plano } & \multicolumn{4}{|c|}{ Coluna } \\
\hline & & $a^{\prime}$ & $\mathbf{b}^{\prime}$ & $\overline{c^{\prime}}$ & d' $^{\prime}$ \\
\hline & & $\begin{array}{l}\text { Espessura } \\
\text { média do } \\
\text { revestimento } \\
(\mathrm{mm})\end{array}$ & $\begin{array}{l}\text { Distância de cada } \\
\text { plano ao ponto } \\
\text { mais interno do } \\
\text { substrato } \\
\text { escaneado }(\mathrm{mm})\end{array}$ & $\begin{array}{c}\text { \% da área com } \\
\text { espessura } \\
\text { mínima de } 25 \mathrm{~mm} \\
\text { de reboco }\end{array}$ & $\begin{array}{l}\text { \% da Área com } \\
\text { espessura } \\
\text { mínima de } 25 \mathrm{~mm} \\
\text { localizada sobre a } \\
\text { alvenaria }\end{array}$ \\
\hline $\mathbf{a}$ & $\begin{array}{l}\text { P0 (eixo das } \\
\text { vigas) }\end{array}$ & 15,2 & 57,8 & $4 \%$ & $100 \%$ \\
\hline b & $\begin{array}{c}\text { P1 (a } 5 \mathrm{~mm} \text { de } \\
\text { P0') }\end{array}$ & 19,1 & 67,1 & $27 \%$ & $96 \%$ \\
\hline C & $\begin{array}{c}\text { P2 (a } 10 \mathrm{~mm} \text { de } \\
\text { P0') }\end{array}$ & 23,6 & 72,1 & $42 \%$ & $95 \%$ \\
\hline d & $\begin{array}{c}\text { P3 (a } 15 \mathrm{~mm} \text { de } \\
\text { P0') }\end{array}$ & 28,3 & 77,1 & $56 \%$ & $93 \%$ \\
\hline e & $\begin{array}{c}\text { P4 (a } 20 \text { mm de } \\
\text { P0') }\end{array}$ & 33,2 & 82,1 & $75 \%$ & $89 \%$ \\
\hline$f$ & $\begin{array}{c}\text { P5 (a } 25 \mathrm{~mm} \text { de } \\
\text { P0') }\end{array}$ & 38,2 & 87,1 & $86 \%$ & $81 \%$ \\
\hline
\end{tabular}


- considerando que o volume entre a superfície escaneada da fachada (substrato) e os planos seriam preenchidos com argamassa de regularização, as espessuras médias calculadas em P3, P4 e P5 (coluna a'-Tabela 7) ficaram acima da espessura de $25 \mathrm{~mm}$, intermediária entre o intervalo de $20 \mathrm{~mm}$ a 30 mm para reboco em fachada indicado pela norma NBR 13749 (ABNT, 1996).

- a distância de cada plano ao ponto mais interno da superfície da fachada (coluna b' -Tabela 7) mostra que nesses locais a espessura de argamassa de revestimento em P0, P1, P2, P3, P4 e P5 chegaria a aproximadamente 2,3; 2,5; 2,$7 ; 2,9 ; 3,1$; e 3,3 vezes, respectivamente, a espessura média de argamassa (25 mm) para fachada considerada no estudo, representando um elevado desperdício de material e de mão de obra, além dos riscos de defeitos nestas regiões críticas.

- em um comparativo entre as colunas c' e d' da Tabela 7, verifica-se que os planos com maior percentual de área com espessura mínima de $25 \mathrm{~mm}$ possuem essas áreas concentradas sobre a alvenaria. Isso comprova que as alvenarias geralmente encontravam-se deslocadas das vigas no sentido interno ao plano e sofreram a influência direta da falta de alinhamento e nivelamento das vigas.

- considerando que, nos planos da Figura 65, as áreas de cor azul escura representam os locais em que cada plano está a uma distância a partir de 25 $\mathrm{mm}$ do substrato escaneado, então, os planos P4 e P5 possuem aproximadamente $75 \%$ e $86 \%$ de sua área, respectivamente, com no mínimo $25 \mathrm{~mm}$ de argamassa.

\subsubsection{Benefícios em volumetria}

$\mathrm{Na}$ tecnologia do escaneamento 3D laser, o cálculo de consumo é feito através de volumetria a partir de uma abrangência de $100 \%$ da área da fachada. O cálculo dos diferentes volumes de argamassa representa a soma das espessuras entre o modelo escaneado da fachada (Figura 63), considerando todas as irregularidades superficiais e cada um dos diferentes planos de estudo.

Partindo do segundo plano de referência (P0') traçado paralelo à fachada e faceando o ponto mais externo da superfície escaneada, conforme ilustrado na Figura 66, observou-se que para atender a condição ideal, em que toda a fachada apresentasse 
$25 \mathrm{~mm}$ de espessura de reboco (Figura 66-e) havia um aumento representativo do consumo de argamassa, potencializando o custo, impacto ambiental e o risco de falhas e defeitos futuros no revestimento.

Por outro lado, as imagens da Figura 66 nos mostram que tanto o plano P1', a $5 \mathrm{~mm}$ de P0', quanto o P2' a 15 mm registram uma área representativa de recobrimento com a espessura recomendada de $25 \mathrm{~mm}$ e com reduções expressivas de consumo de argamassa (Tabela 8). Sendo assim, tratar os pontos que não atendem à espessura de $25 \mathrm{~mm}$ a fim de garantir seu desempenho pode representar ganhos representativos de qualidade, durabilidade e econômicos.

Tabela 8. Resultados a partir do $2^{\circ}$ plano de referência (Fonte: Elaborado pelo autor).

\begin{tabular}{|c|c|c|c|c|c|c|}
\hline & \multirow[b]{3}{*}{ Plano } & \multicolumn{4}{|c|}{ Coluna } \\
\hline & & & $\mathbf{a}^{\prime}$ & $\mathbf{b}^{\prime}$ & $\mathbf{c}^{\prime}$ & $\mathbf{d}^{\prime}$ \\
\hline & & & $\begin{array}{c}\text { Consumo de } \\
\text { Argamassa } \\
\left(\mathrm{m}^{3}\right)\end{array}$ & $\begin{array}{c}\text { \% de aumento de } \\
\text { consumo em } \\
\text { relação a P0' }\end{array}$ & $\begin{array}{c}\text { \% da Área com } \\
\text { espessura } \\
\text { mínima de } 25 \mathrm{~mm} \\
\text { de reboco }\end{array}$ & $\begin{array}{c}\text { \% da Área com } \\
\text { espessura } \\
\text { mínima de } 25 \mathrm{~mm} \\
\text { localizada sobre a } \\
\text { estrutura de } \\
\text { concreto }\end{array}$ \\
\hline \multirow{4}{*}{$\frac{\pi}{\frac{\pi}{5}}$} & $\mathbf{a}$ & $\begin{array}{c}\text { P0' (ponto mais } \\
\text { externo) }\end{array}$ & 2,59 & - & $39 \%$ & $46 \%$ \\
\hline & b & $\begin{array}{c}\mathrm{P} 1^{\prime} \text { (a } 5 \mathrm{~mm} \text { de } \\
\text { P0') }\end{array}$ & 3,05 & $18 \%$ & $53 \%$ & $57 \%$ \\
\hline & C & $\begin{array}{c}\text { P2' (a } 15 \mathrm{~mm} \text { de } \\
\text { P(') }\end{array}$ & 3,95 & $53 \%$ & $82 \%$ & $100 \%$ \\
\hline & d & $\begin{array}{c}\text { P3' (a } 25 \mathrm{~mm} \text { de } \\
\text { P0') }\end{array}$ & 4,85 & $87 \%$ & $100 \%$ & $0 \%$ \\
\hline
\end{tabular}

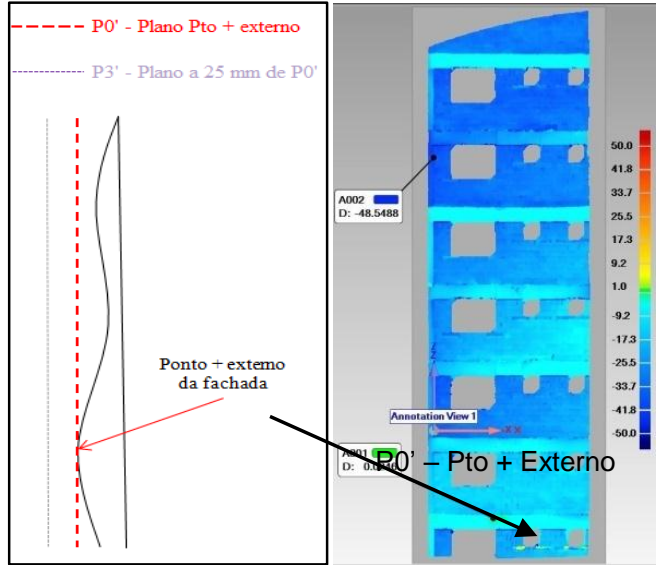

(a)

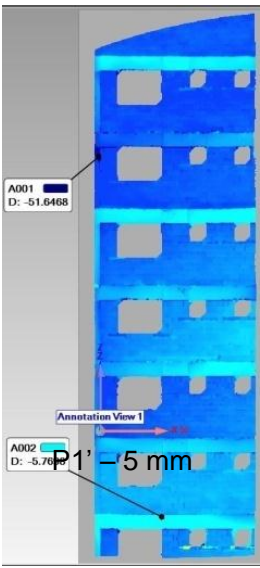

(c)

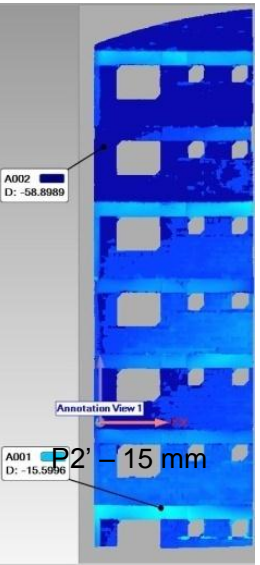

(d)

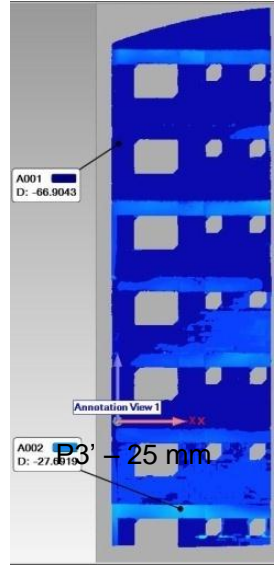

(e)

Figura 66. Planos traçados a partir do $2^{\circ}$ plano de referência. (Fonte: T1 Engenharia Digital). 
Os resultados consolidados na Tabela 8 mostram que:

- o plano de referência P0' consome um volume de 2,59 m³ de argamassa, porém apenas 39\% da área total escaneada apresenta espessura mínima de $25 \mathrm{~mm}$;

- o plano P3' localizado a 25 mm de P0', ou seja, situação em que $100 \%$ da fachada apresentaria um revestimento mínimo $25 \mathrm{~mm}$ de argamassa, aumentou o consumo em $87 \%$, totalizando $4,85 \mathrm{~m}^{3}$;

- em contrapartida, o plano P2' a $15 \mathrm{~mm}$ da referência apresentou um aumento de consumo de 53\%, total de $3,95 \mathrm{~m}^{3}$ de argamassa e $82 \%$ da área com espessuras a partir de $25 \mathrm{~mm}$;

- já no plano P1', a 5 mm de P0', há um aumento de apenas $18 \%$ no consumo, representando um recobrimento da fachada de 53\% com espessuras mínimas de $25 \mathrm{~mm}$;

- nos planos P1' e P2', 57\% e 100\%, respectivamente, da área com espessura mínima de $25 \mathrm{~mm}$ estão sobre a estrutura de concreto (coluna d'), sendo possível pensar em uma solução para esse substrato atuar com espessuras menores sem comprometer o desempenho e durabilidade.

\subsubsection{Potencial econômico da técnica}

Embora Boehler e Marbs (2003) tenham classificado a varredura a laser como uma técnica de custo proibitivo na época de seu estudo, já era percebido o retorno sobre o investimento em comparação com os métodos de levantamento convencionais. Assim, um ponto de suma importância levantado durante o estudo foi a viabilidade econômica do uso da técnica em face dos ganhos financeiros reais gerados. Para isso, calculou-se a economia gerada pela redução de espessura da argamassa nos planos P0', P1'e P2' em relação ao plano P3' e comparou-se com o custo para a realização do escaneamento (Tabela 9).

A análise levou em consideração o consumo de argamassa calculado pelo software em cada um dos planos e o custo da argamassa de regularização de fachada aplicada de $R \$ 1.417,00 / \mathrm{m}^{3}$, valor médio praticado na cidade de São Paulo no primeiro semestre de 2013 (Fonte: Sinduscon - SP). Nesse custo está considerado material, mão de obra e equipamento e os valores encontrados com base na área dos sete 
pavimentos escaneados de uma das fachadas foram extrapolados para os 24 pavimentos dessa mesma fachada.

Tabela 9. Volumes vs custos da argamassa nos diferentes planos de estudo (Fonte:

Elaborado pelo autor).

\begin{tabular}{|c|c|c|c|c|c|c|}
\hline \multirow{2}{*}{$\begin{array}{c}\text { Plano de } \\
\text { Estudo }\end{array}$} & \multirow{2}{*}{$\begin{array}{l}\text { Espessura } \\
\qquad(\mathrm{mm})\end{array}$} & \multicolumn{2}{|c|}{$\begin{array}{c}\text { Consumo de } \\
\text { Argamassa (t) }\end{array}$} & \multirow[b]{2}{*}{ Custo* $(\mathrm{R} \$)$} & \multirow{2}{*}{$\begin{array}{c}\text { Redução de } \\
\text { volume em } \\
\text { relação a P3' } \\
\text { (plano a } 25 \text { mm } \\
\text { de P0') (\%) }\end{array}$} & \multirow{2}{*}{$\begin{array}{l}\text { Redução de } \\
\text { custo em } \\
\text { relação a P3' } \\
(\mathrm{R} \$)\end{array}$} \\
\hline & & $\begin{array}{c}\text { Na área } \\
\text { escaneada (7 } \\
\text { pavimentos) }\end{array}$ & $\begin{array}{c}\mathrm{Na} \\
\text { fachada }\end{array}$ & & & \\
\hline P0' & 0 & 4,4 & 15,1 & $\mathrm{R} \$ 12.582,96$ & $-47 \%$ & $-\mathrm{R} \$ 11.222,64$ \\
\hline $\mathrm{P} 1^{\prime}$ & 5 & 5,3 & 18,1 & $\mathrm{R} \$ 15.060,69$ & $-37 \%$ & $-\mathrm{R} \$ \quad 8.744,91$ \\
\hline P2' & 15 & 6,8 & 23,3 & $\mathrm{R} \$ 19.433,14$ & $-18 \%$ & $-\mathrm{R} \$ \quad 4.372,46$ \\
\hline P3' & 25 & 8,3 & 28,6 & $\mathrm{R} \$ 23.805,60$ & $0 \%$ & $\mathrm{R} \$$ \\
\hline
\end{tabular}

${ }^{*}$ Custo de argamassa aplicada: $\mathrm{R} \$ 1.417,00 / \mathrm{m}^{3}$

Consumo de argamassa: $1,7 \mathrm{t} / \mathrm{m}^{3}$

Com isso, pelos resultados da Tabela 8 e da Tabela 9, observam-se:

- Plano P0' - 39\% da área com espessura mínima de 25 mm (Tabela 8 - coluna c') e uma redução de $47 \%$ em relação a P3' no consumo de argamassa (Tabela 9), resultando em uma economia de $\mathrm{R} \$ 11.222,64$;

- Plano P1' - 53\% da área com espessura mínima de 25 mm (Tabela 8 - coluna c') e uma redução de $37 \%$ em relação a P3' no consumo de argamassa (Tabela $9)$, resultando em uma economia de $\mathrm{R} \$ 8.744,91$;

- Plano P2' - 82\% da área com espessura mínima de 25 mm (Tabela 8 - coluna c') e uma redução de 19\% em relação a P3' no consumo de argamassa (Tabela 9), resultando em uma economia de $R \$ 4.372,46$.

Levando em consideração um valor estimado de $\mathrm{R} \$ 5.000,00$ (cinco mil reais) para a realização do escaneamento em uma fachada com a análise dos dados incluída, o uso da tecnologia se pagou e gerou um saldo positivo nos planos P0' e P1', porém apenas 39\% e 53\% da área apresentavam-se com espessura mínima de $25 \mathrm{~mm}$. Já no plano P2', apesar do déficit de $R \$ 627,54$ para cobrir o custo do serviço de escaneamento, verificou-se um percentual de $82 \%$ da área com espessura mínima de $25 \mathrm{~mm}$. 


\subsubsection{Considerações}

O nível de detalhamento das imagens, o alcance e a portabilidade dos equipamentos atualmente disponíveis e o grau de desenvolvimento dos softwares tornam a técnica de escamento 3D laser precisa e rápida para mapeamento da fachada, porém seu uso depende de cumprir condições de contorno intrínsecas ao canteiro de obras para evitar elementos de obstrução à leitura do escâner, como detalhes arquitetônicos (sacadas) e elementos dispostos entre o escâner e a fachada (andaimes e telas), que prejudicam o mapeamento da planicidade e o cálculo preciso do volume de argamassa

Essas condições de contorno podem gerar alterações ou intervenções na rotina/etapas da obra, como atrasos de cronograma devido a instalação tardia de andaimes e a remoção de telas fachadeiras.

Pela análise dos dados, pequenas áreas críticas mais internas ao plano da fachada e localizados em sua maior parte sobre a alvenaria, e pontos mais externos, localizados principalmente sobre a estrutura, influenciam a espessura final de argamassa de revestimento, podendo chegar a 3,3 vezes a espessura referência de $25 \mathrm{~mm}$ adotada no estudo, representando desperdício de material e de mão de obra, além de potencializar os riscos de defeitos.

\subsection{Aplicação da termografia infravermelha na identificação de defeitos de fachada}

Nas diferentes etapas de laboratório, campo e obra, a análise foi realizada em diferentes condições de gradiente térmico para permitir a visualizar qualitativa dos defeitos com a camera térmica e software utilizados. Os resultados são apresentados como um todo, visando facilitar a compreensão e evitar a repetição da estrutura de apresentação.

\subsubsection{Condição de baixo gradiente térmico}

Como primeira análise foi realizada a imagem térmica das superfícies dos painéis na condição de baixo gradiente térmico. Condição alcançada deixando os painéis em repouso durante 24 horas no Hall Tecnológico da Escola Politécnica, local com oscilação térmica de $\pm 2^{\circ} \mathrm{C}$. Após aferir a equivalência de temperaturas entre painéis 
e laboratório, foram realizados os termogramas. Esse teste avaliou a possibilidade de a câmera térmica identificar defeitos visíveis e não visíveis a olho nu com diferenças mínimas de temperatura entre a região com defeito e seu entorno.

Observou-se que em razão do baixo fluxo de calor, não é possível fazer distinção entre a argamassa de assentamento da alvenaria e os blocos de concreto no termograma, materiais que apresentam valores de emissividade muito próximos correspondentes a 0,92 e 0,94, respectivamente (Figura 67-a).

Para comprovar que não se trata de uma falha de ajuste do equipamento ou do termograma, apoiou-se a palma da mão sobre a superfície do substrato por aproximadamente 5 segundos comprovando a regulagem correta de foco (Figura 67b).

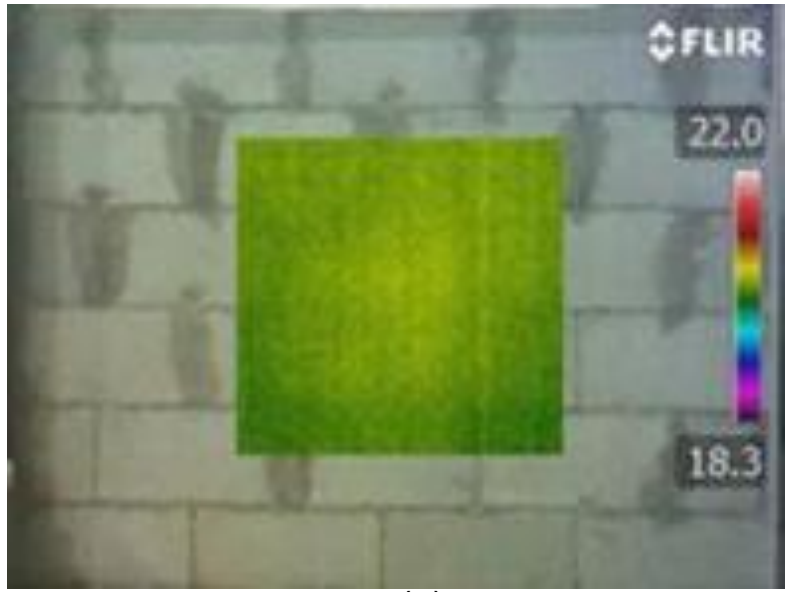

(a)

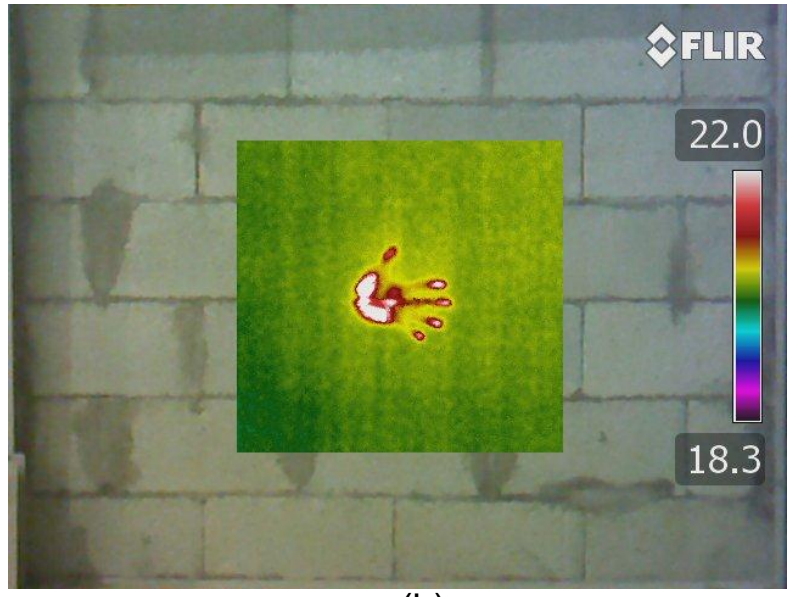

(b)

Figura 67. (a) Termograma de painel em alvenaria de bloco de concreto na condição de baixo gradiente térmico; (b) Ilustração de regulagem de foco. (Fonte: Elaborado pelo autor).

$\mathrm{Na}$ alvenaria em bloco de concreto foi possível observar apenas as juntas verticais de assentamento que não apresentavam argamassa (Figura 68). 


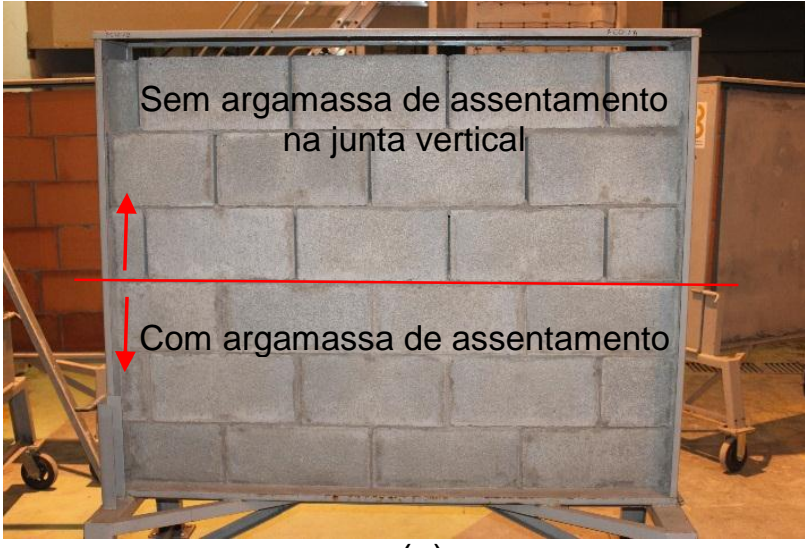

(a)

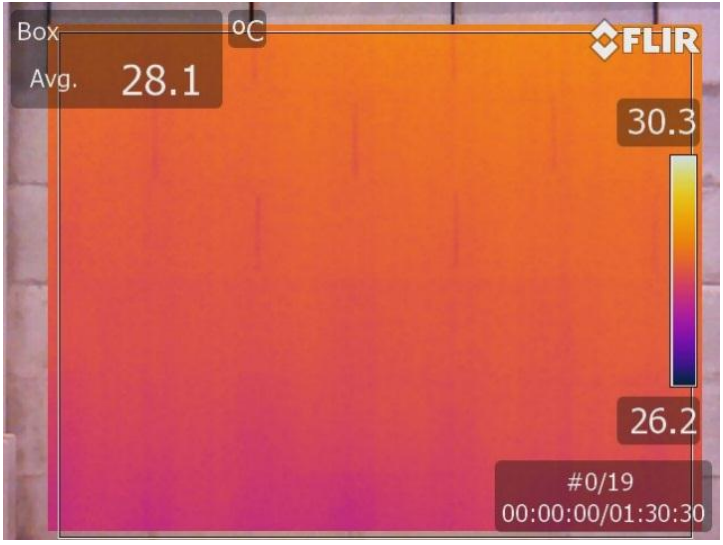

(b)

Figura 68. (a) Imagem do Painel PCO1-B com juntas verticais de assentamento da alvenaria preenchidas e não preenchidas com argamassa; (b) Termograma do painel PCO1-B rebocado na condição de baixo gradiente térmico. (Fonte: Elaborado pelo autor).

Para o conjunto argamassa de assentamento de alvenaria e tijolos cerâmicos (Figura 69. Termograma de painel PCE1-B em alvenaria de tijolo cerâmico na condição de baixo gradiente térmico. (Fonte: Elaborado pelo autor).Figura 69), com valores de emissividade de 0,92 e 0,88, respectivamente, é possível identificar a localização das juntas pelo termograma.

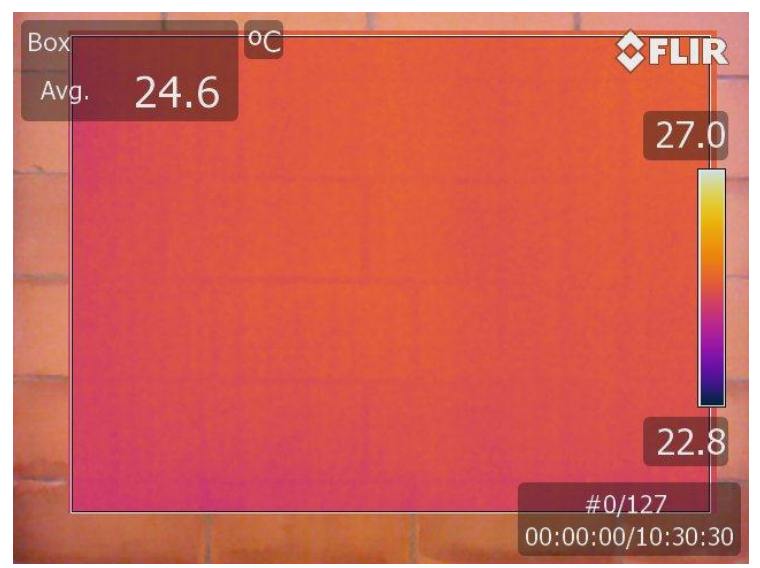

Figura 69. Termograma de painel PCE1-B em alvenaria de tijolo cerâmico na condição de baixo gradiente térmico. (Fonte: Elaborado pelo autor).

Não foi possível identificar as juntas de assentamento de alvenaria de tijolo cerâmico (Figura 70-a) ou bloco de concreto (Figura 70-b) sob o reboco, sejam elas preenchidas ou não com argamassa. 


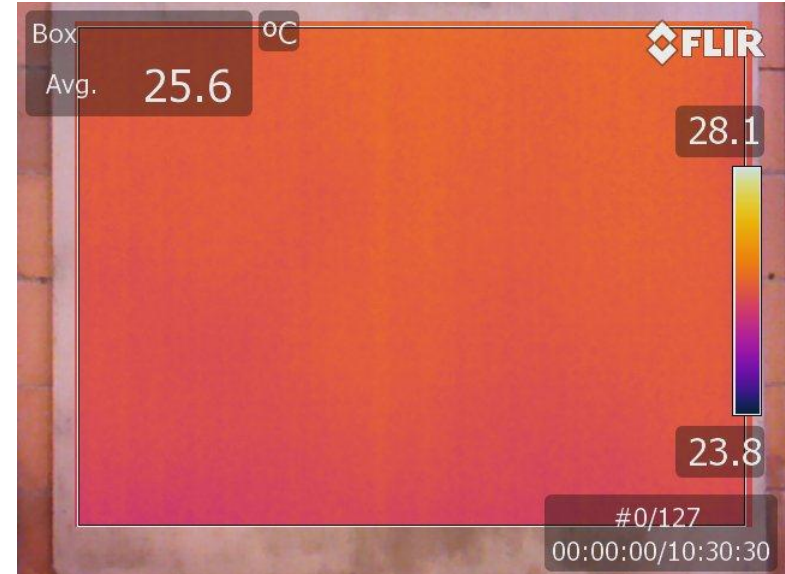

(a)

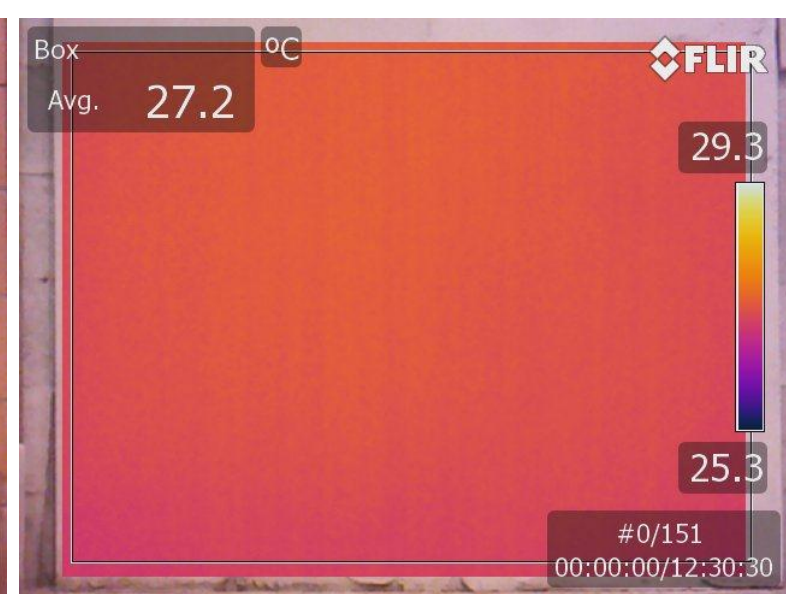

(b)

Figura 70. (a) Termograma de painel PCE1-A em alvenaria de tijolo cerâmico rebocado na condição de baixo gradiente térmico; (b) Termograma do painel PCO1-A em alvenaria de bloco de concreto rebocado na condição de baixo gradiente térmico. (Fonte: Elaborado pelo autor).

Fissuras visíveis a olho nu na junta de assentamento da alvenaria (Figura 71-a e Figura 71-b) são visíveis nos termogramas a distâncias curtas de $50 \mathrm{~cm}$, porém à distância de $323 \mathrm{~cm}$, adotada como padrão no estudo, se tornam imperceptíveis.

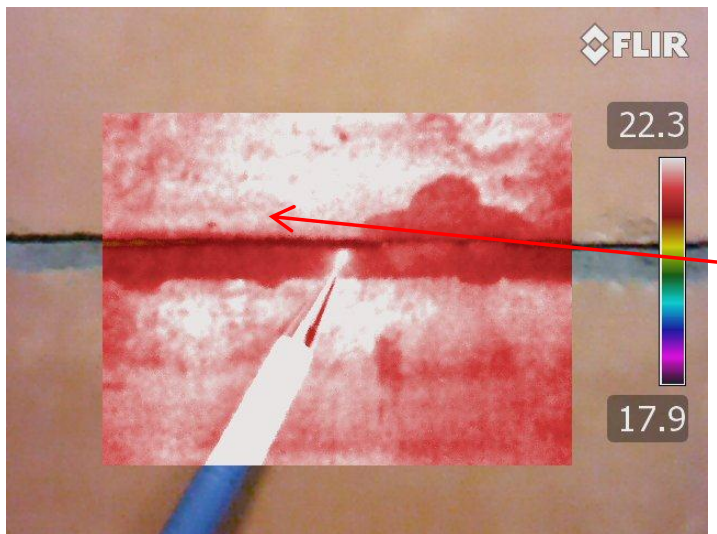

(a)

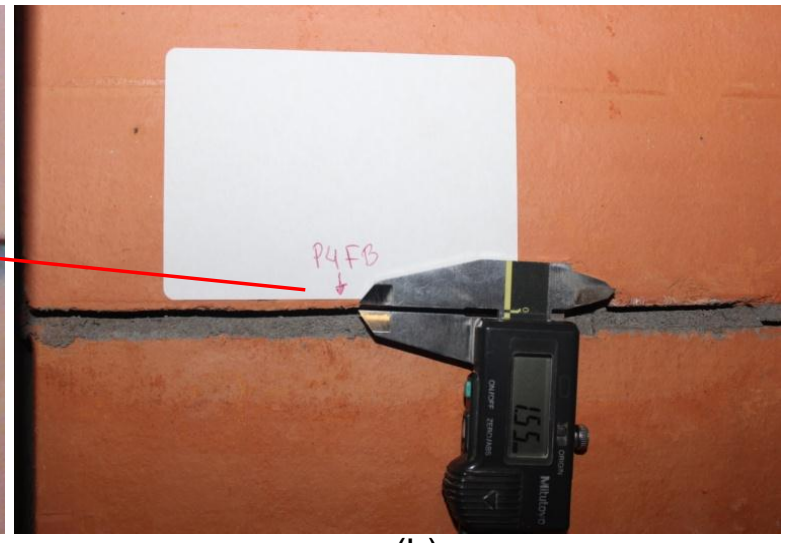

(b)

Figura 71. (a) Termograma de fissuras visíveis a olho nu no painel PCE1-B na condição de baixo gradiente térmico; (b) Imagem de fissuras na junta de assentamento da alvenaria no painel PCE1-B. (Fonte: Elaborado pelo autor).

Fissuras visíveis a olho nu no revestimento de argamassa (Figura 72-a e Figura 72b), descolamentos sob o reboco independentemente do tamanho (Figura 73-a e b e Figura 74-a e b), descolamentos (Figura 75-a e b e Figura 76-a e b) e vazios de argamassa colante sob o revestimento cerâmico (Figura 77-a e b) não foram visíveis na condição de baixo gradiente térmico entre os defeitos e as áreas em volta. 


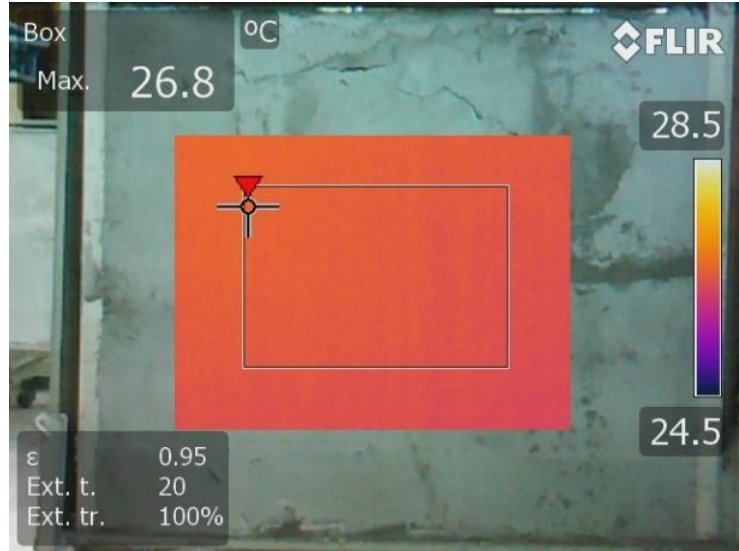

(a)

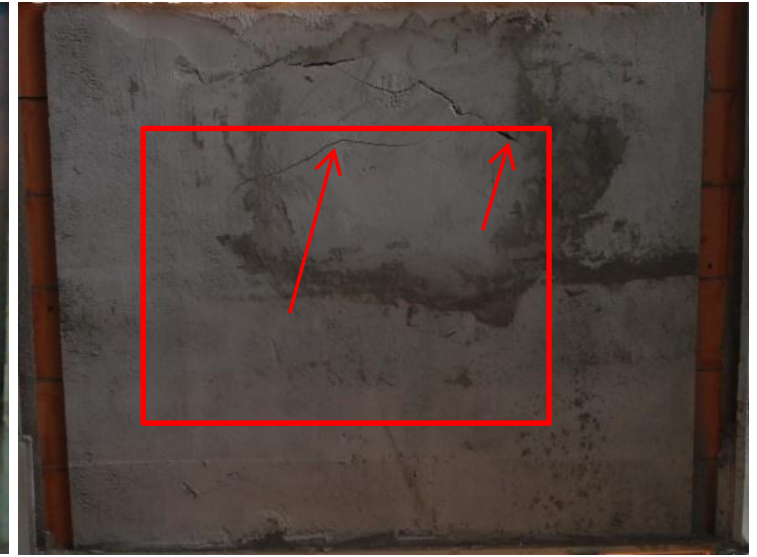

(b)

Figura 72. (a) Termograma de fissuras do painel PCE2-B na condição de baixo gradiente térmico; (b) Indicação das fissuras visíveis a olho nu no painel PCE2-B. (Fonte: Elaborado pelo autor).

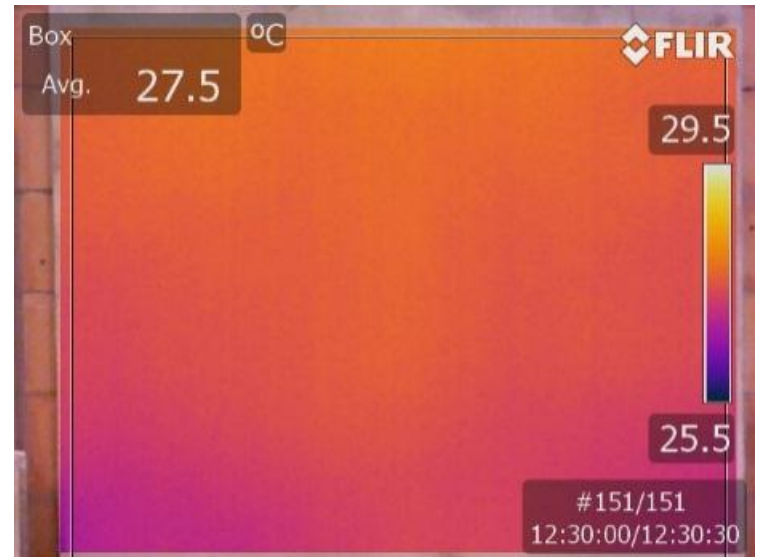

(a)

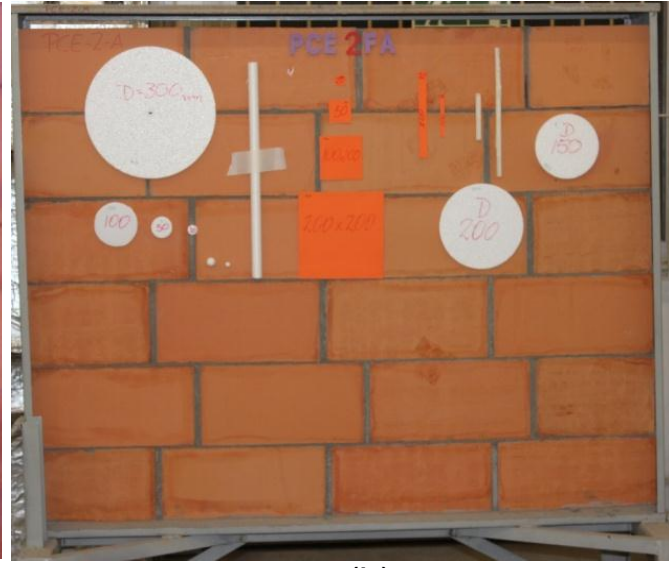

(b)

Figura 73. (a) Termograma da superfície rebocada do painel PCE2-A na condição de baixo gradiente térmico; (b) Indicação dos defeitos sob o reboco no painel PCE2-A. (Fonte:

Elaborado pelo autor).

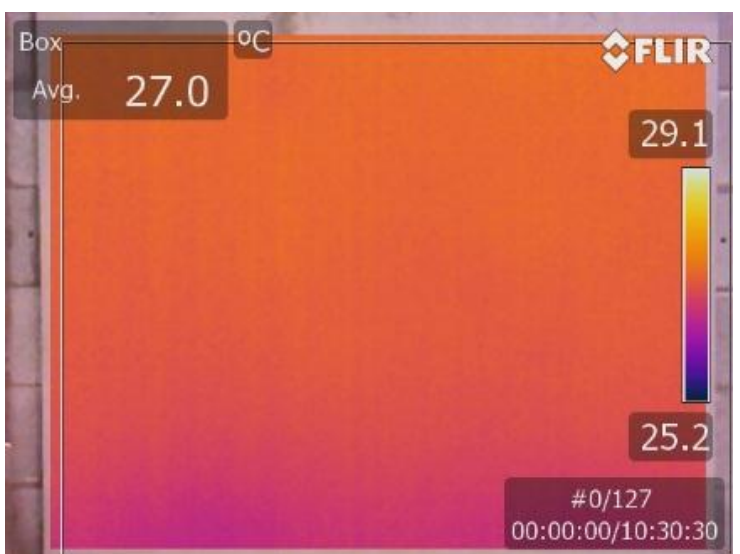

(a)

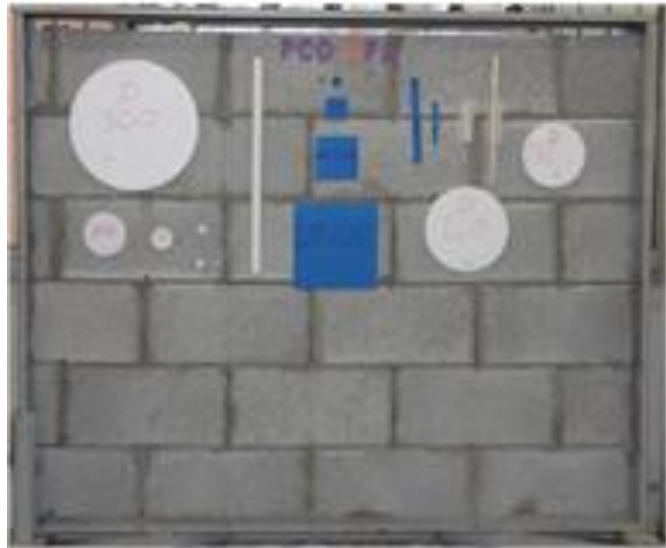

(b)

Figura 74. (a) Termograma da superfície rebocada do painel PCO2-A na condição de baixo gradiente térmico; (b) Indicação dos defeitos sob o reboco no painel PCO2-A. (Fonte:

Elaborado pelo autor). 


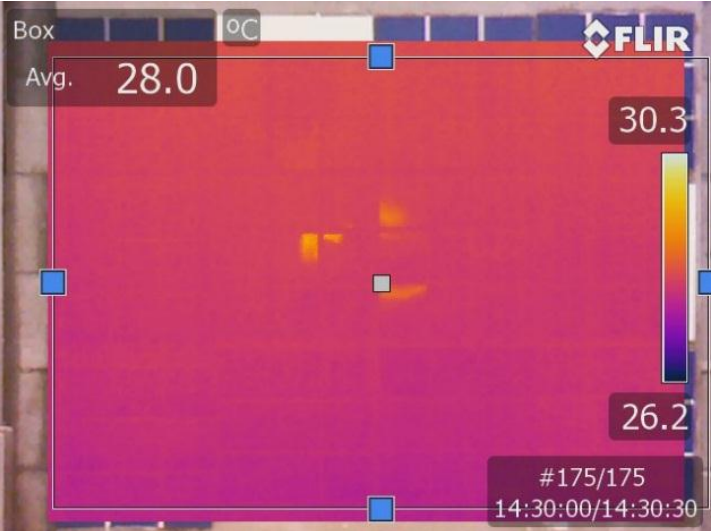

(a)

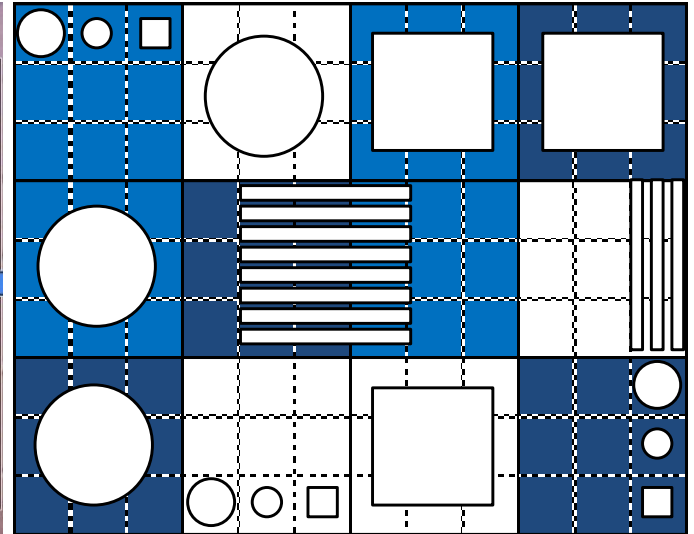

(b)

Figura 75. (a) Termograma da superfície revestida com cerâmica do painel PCO3-A na condição de baixo gradiente térmico; (b) llustração dos defeitos de descolamento sob o revestimento cerâmico do painel PCO3-A. (Fonte: Elaborado pelo autor).

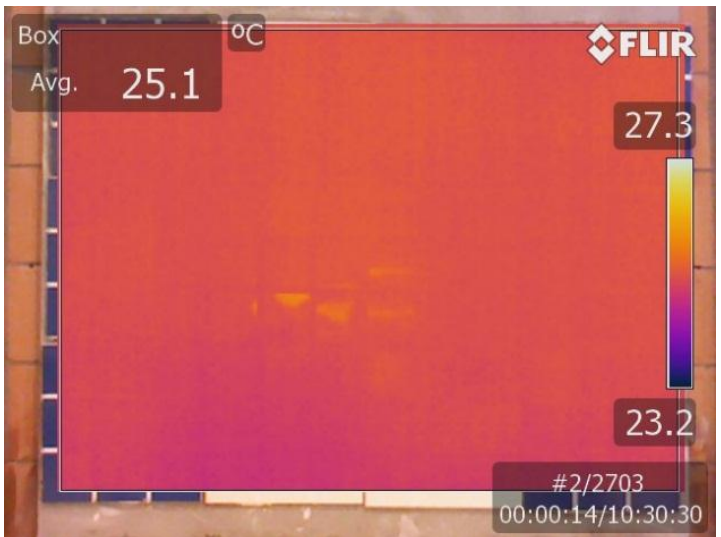

(a)

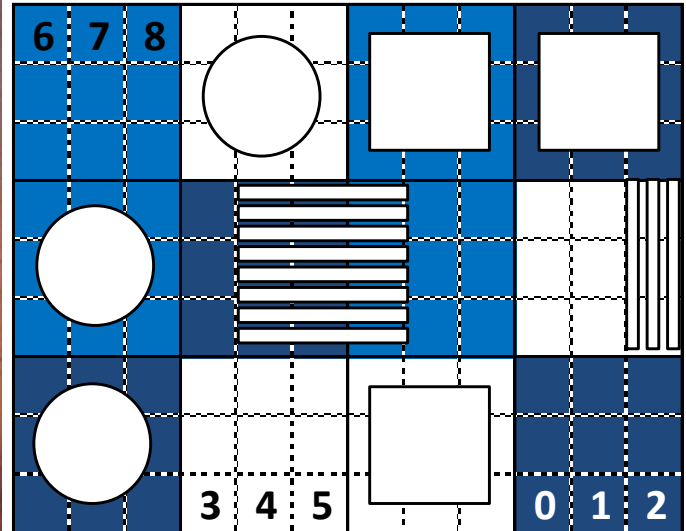

(b)

Figura 76. (a) Termograma da superfície revestida com cerâmica do painel PCE3-B na condição de baixo gradiente térmico; (b) Ilustração dos defeitos de descolamento sob o revestimento cerâmico do painel PCE3-B. (Fonte: Elaborado pelo autor).

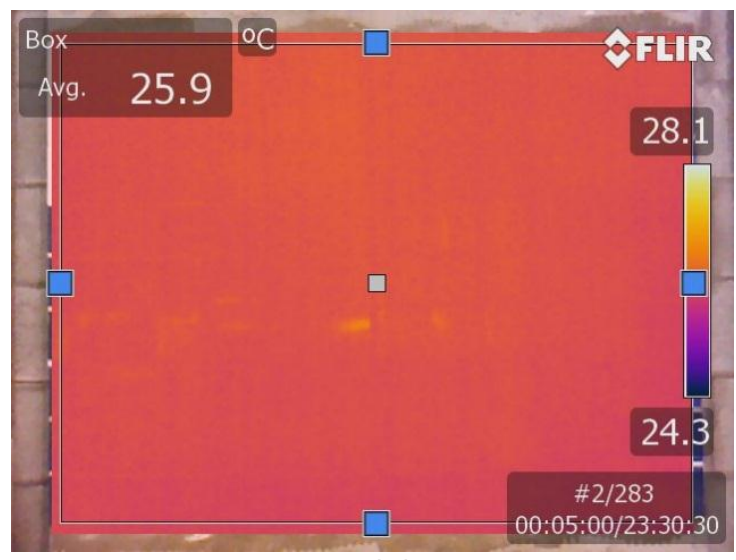

(a)

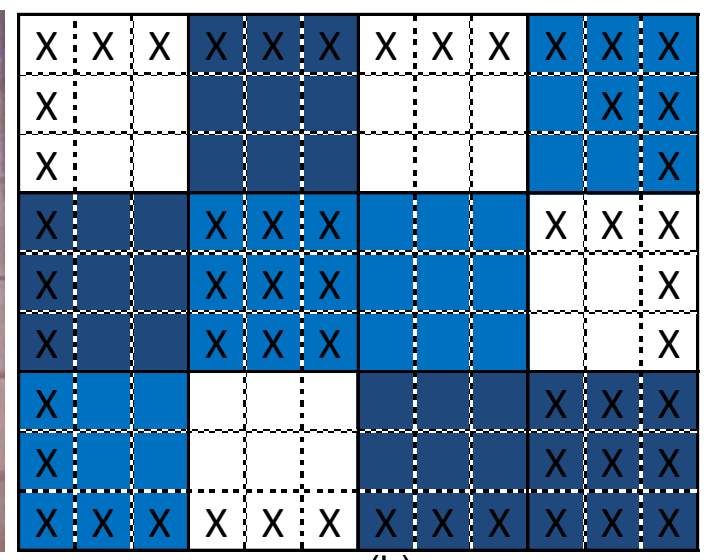

(b)

Figura 77. (a) Termograma da superfície revestida com cerâmica do painel PCO3-B na condição de baixo gradiente térmico; (b) Ilustração dos defeitos de vazios de argamassa de assentamento sob o revestimento cerâmico do painel PCO3-B. (Fonte: Elaborado pelo autor). 


\subsubsection{Condição de Elevado Gradiente Térmico}

\subsubsection{Defeitos de descolamento/vazios nos painéis}

A análise dos termogramas para identificar defeitos de vazios/descolamento sob o reboco foi focada nos painéis PCE2-A e PCO2-A, realizada em condições de resfriamento natural e forçado com água após aquecimento com painel térmico na etapa de laboratório e na condição de aquecimento ao sol e resfriamento à sombra na etapa de campo. Ambas consideraram a forma, as dimensões e a espessura dos defeitos nas análises dos termogramas.

\section{- Laboratório}

No resfriamento à temperatura ambiente foram observados os seguintes padrões de comportamento nos termogramas:

○ imediatamente após o aquecimento:

- áreas de vazios/descolamentos apresentam maiores valores de temperatura devido ao espaço de ar formado entre o revestimento e o substrato gerando acúmulo de energia térmica durante o tempo de exposição ao aquecimento;

- mesmo com pequenas movimentações na posição dos defeitos durante a etapa de aplicação da argamassa de revestimento, é possível observar com precisão a forma e a posição dos defeitos quadrados e circulares de dimensões até $50 \mathrm{~mm}$ feitos de EVA e isopor, respectivamente (destacados em vermelho na Figura 78-a), e o defeito cilíndrico de silicone com dimensões de $20 \mathrm{~mm}$ de diâmetro por $500 \mathrm{~mm}$ de comprimento, este último a $5 \mathrm{~mm}$ da superfície do reboco (seta preta na Figura 78-a);

- apesar de o defeito esférico de isopor com diâmetro de $20 \mathrm{~mm}$ ser identificado (seta branca na Figura 78-a) devido à proximidade de cinco $\mathrm{mm}$ da superfície, assim como os defeitos retangulares de $10 \times 100 / 20 \times$ 200 e cilíndros de $10 \times 100 / 10 \times 300$ feitos de EVA e madeira, respectivamente (retângulo preto na Figura 78-a) serem visualizados levemente, podem ser facilmente confundidos com "manchas térmicas" causadas por condições variadas da superfície do reboco, como imperfeições de acabamento, diferenças de rugosidade da argamassa, áreas com diferentes tonalidades da própria argamassa (Figura 79); 
- os defeitos de quadrados e circulares de $20 \mathrm{~mm}$ feitos de EVA e isopor, respectivamente (setas azuis na Figura 78-b), esfera de isopor de10 mm (seta verde na Figura 78-b) não são visíveis.

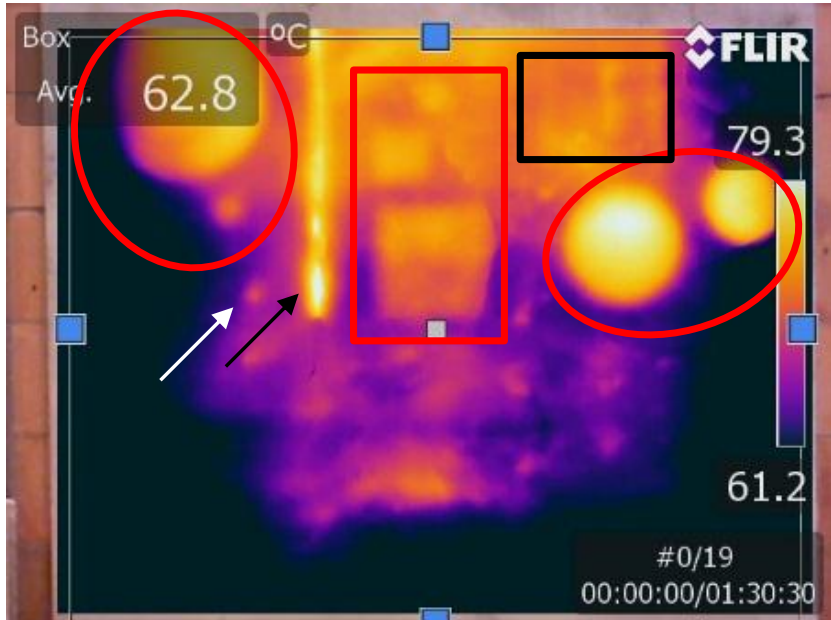

(a)

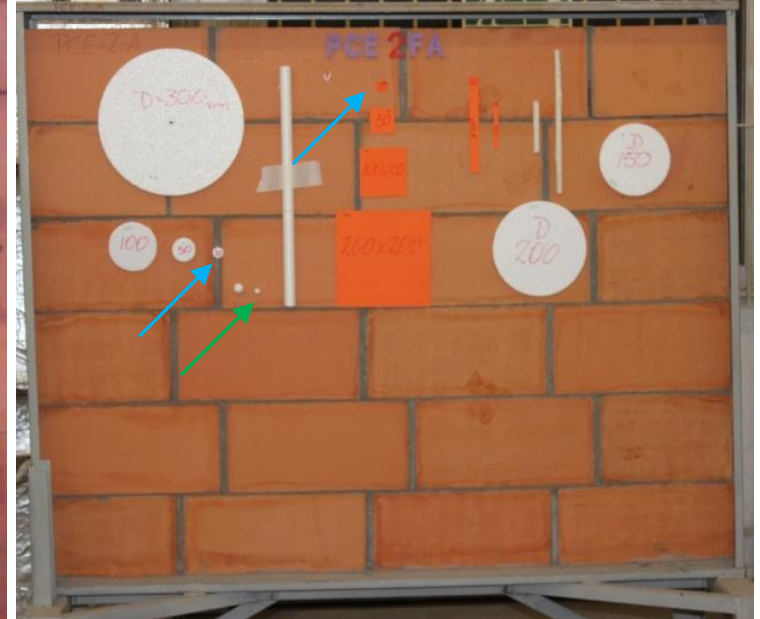

(b)

Figura 78. (a) Termograma do painel PCE2-A com grupos de defeitos destacados; (b) Defeitos sob o reboco no painel PCE2-A. (Fonte: Elaborado pelo autor).

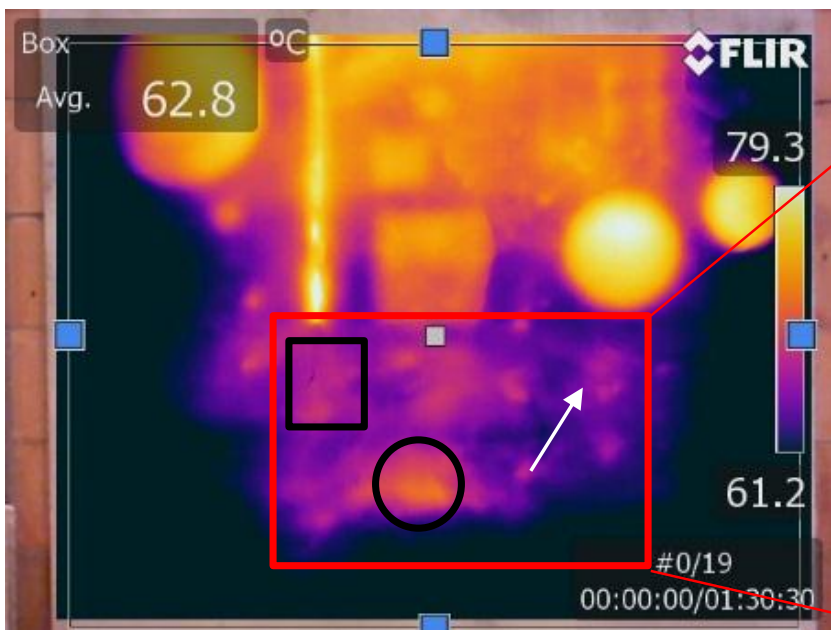

(a)

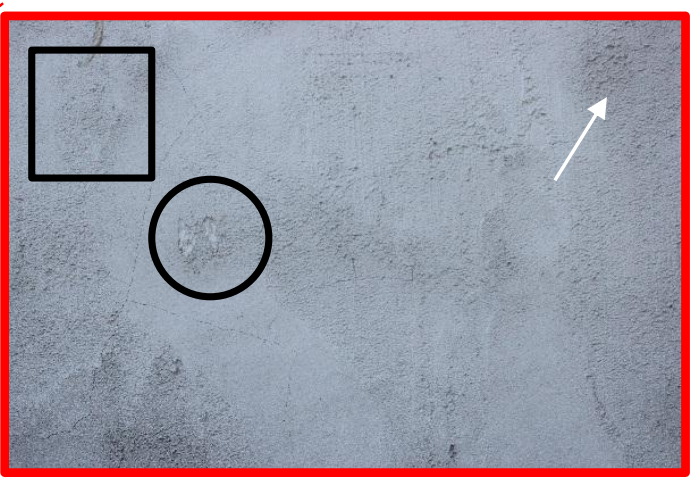

(b)

Figura 79. Área de manchas térmicas devido a imperfeições de acabamento (triângulo), diferenças de rugosidade da argamassa (retângulo), áreas com diferentes tonalidades da própria argamassa (setas brancas) observados no painel PCE2-A. (Fonte: Elaborado pelo autor).

- passados os primeiros minutos de resfriamento:

- os defeitos apresentam uma temperatura mais baixa que as áreas de não defeitos (Figura 80-a); 
- os defeitos são visualmente menos intensos (seta branca da Figura 80-a) que o momento imediatamente após o aquecimento (seta preta na Figura 80-b) se destacando menos em relação às áreas de não defeitos;

- as bordas apresentam-se ligeiramente menos definidas em razão da dispersão térmica (círculo preto na Figura 80-a) similar ao momento imediatamente após o aquecimento (círculo branco na Figura 80-b), fazendo com que as dimensões dos defeitos fiquem ligeiramente maiores que as originais;

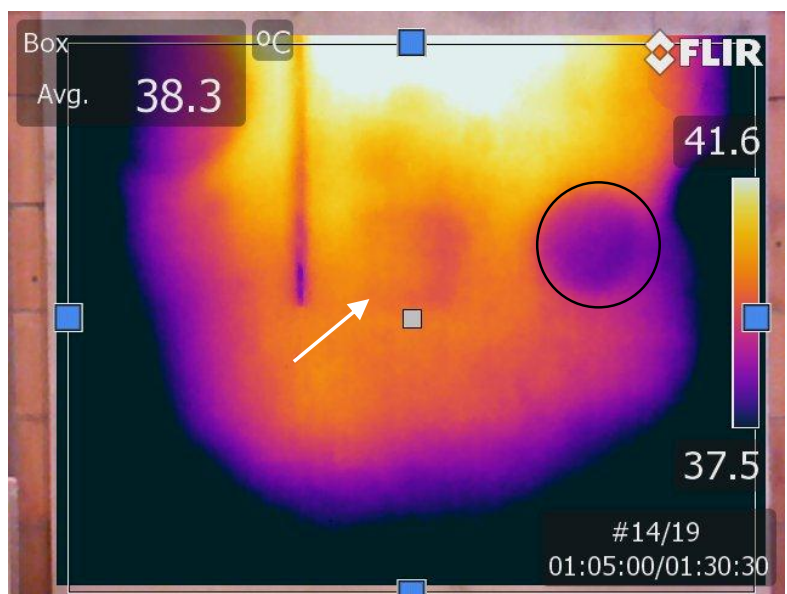

(a)

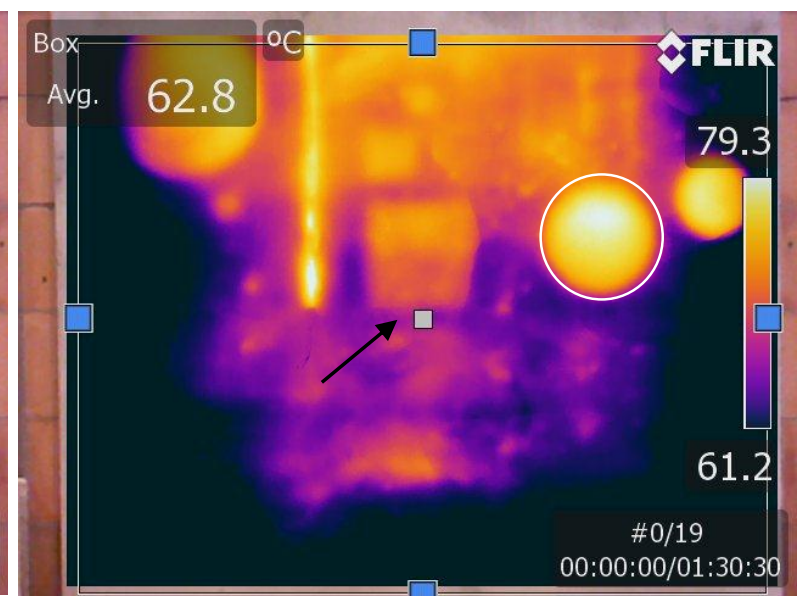

(b)

Figura 80. Termograma do painel PCE2-A: (a) 65 minutos após início do resfriamento; (b) Após aquecimento. (Fonte: Elaborado pelo autor).

- analisando o termograma com a melhor visualização dos defeitos é possível observar com precisão os defeitos quadrados e circulares de dimensões até $100 \mathrm{~mm}$ feitos de EVA e isopor, respectivamente (destacados em vermelho na Figura 81-a), e o defeito cilíndrico de silicone com dimensões de $20 \mathrm{~mm}$ de diâmetro por $500 \mathrm{~mm}$ de comprimento, este último a $5 \mathrm{~mm}$ da superfície do reboco (seta preta na Figura 81-a);

- os defeitos quadrados e circulares de $50 \mathrm{~mm}$ feitos de EVA e isopor, respectivamente, e o defeito esférico com diâmetro de $20 \mathrm{~mm}$ de isopor (setas brancas na Figura 81-a) passam a ser visualizados apenas levemente;

- as chamadas "manchas térmicas" observadas na Figura 81 diminuem bastante até desaparecerem por completo à medida que o resfrimennto avança (retângulo branco na Figura 81-a); 
- nessa condição, além dos defeitos quadrados e circulares de $20 \mathrm{~mm}$ feitos de EVA e isopor, respectivamente (setas azuis na Figura 81-b), esfera de isopor de $10 \mathrm{~mm}$ (seta verde na Figura 81-b, os defeitos retangulares de $10 \times 100 / 20 \times 200$ e cilindros de $10 \times 100 / 10 \times 300$ feitos de EVA e madeira, respectivamente (retângulo preto na Figura $81-b$ ), e as letras "PCE2FA" de EVA no alto do painel (elipse preta na Figura 81-b), antes visíveis no momento imediatamente após o aquecimento, também passam a não serem mais visíveis.

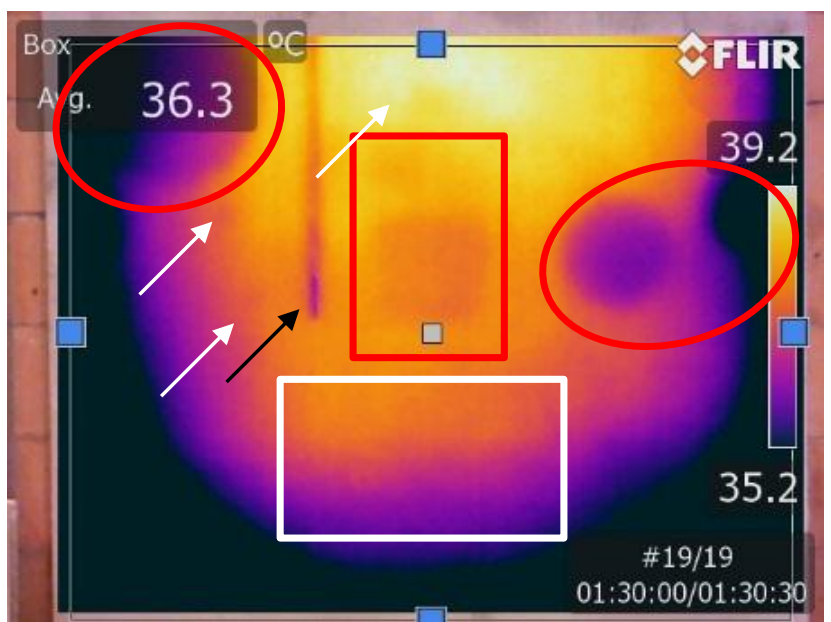

(a)

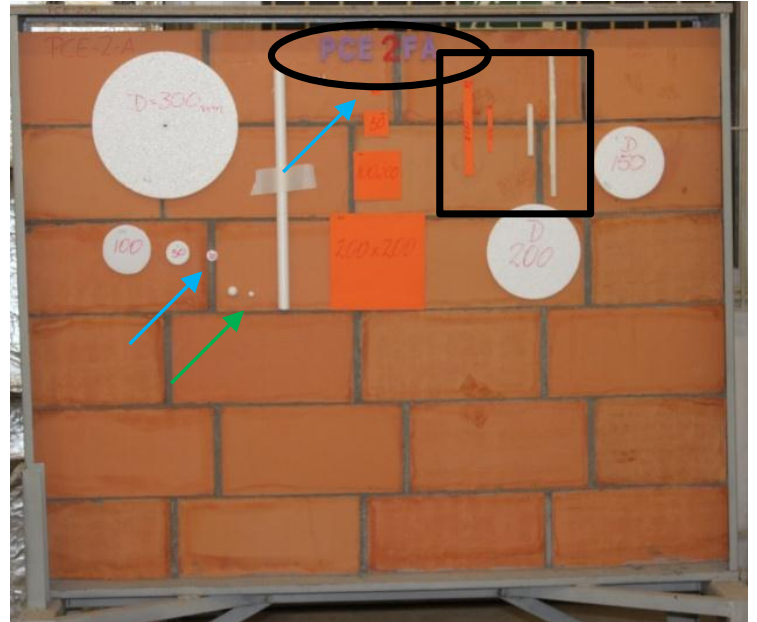

(b)

Figura 81. (a) Termograma do painel PCE2-A noventa minutos após início do resfriamento; (b) defeitos inseridos sob reboco. (Fonte: Elaborado pelo autor).

Por serem mais espessos (8 a $10 \mathrm{~mm}$ ), os defeitos de desplacamento simulados com isopor ficam mais próximos da superfície e resultam em espessuras menores de reboco que os defeitos simulados com EVA (2 a $3 \mathrm{~mm}$ ), mais profundos e por consequência posicionados sob rebocos mais espessos. Em função dessa característica dos defeitos, também foram observados os seguintes padrões de comportamento:

- em função da espessura do revestimento de argamassa sobre o defeito de desplacamento:

- quanto menor a espessura do revestimento de argamassa na área do defeito:

- mais rápido e intenso é o aquecimento/resfriamento;

- mais visível é o defeito no termograma devido ao maior gradiente térmico em relação à área sem defeito (seta preta na Figura 82 
mostrando o círculo feito de isopor) quando comparado com o defeito mais profundo (seta branca na Figura 82 mostrando o quadrado feito de EVA) apesar de ser possível identificar claramente a forma;

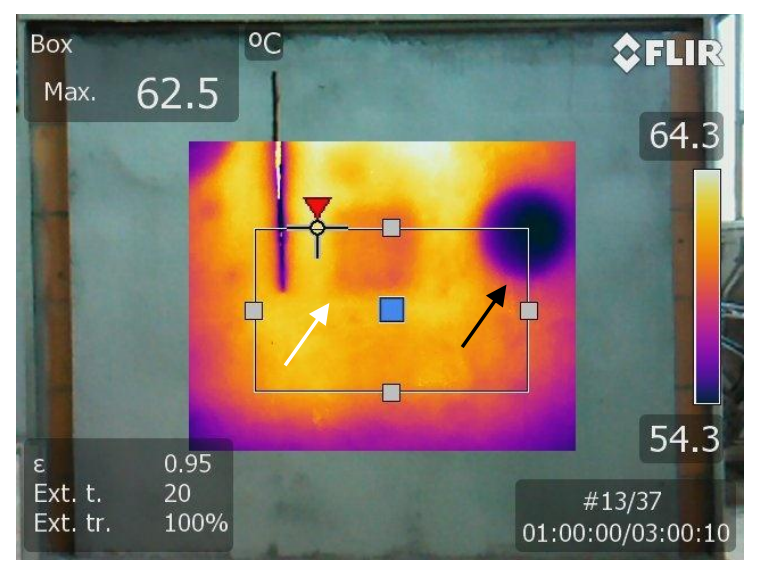

Figura 82. Termograma do painel PCE2-A sessenta minutos após iniciado o resfriamento. (Fonte: Elaborado pelo autor).

- o tempo de visualização do defeito (setas pretas na Figura 83) é praticamente o mesmo para diferentes espessuras do revestimento de argamassa, pois, apesar do defeito mais profundo ter aquecido menos que o mais superficial, ele resfria mais lentamente, podendo inviabilizar a diferenciação pelo requisito espessura em idades mais avançadas do resfriamento.

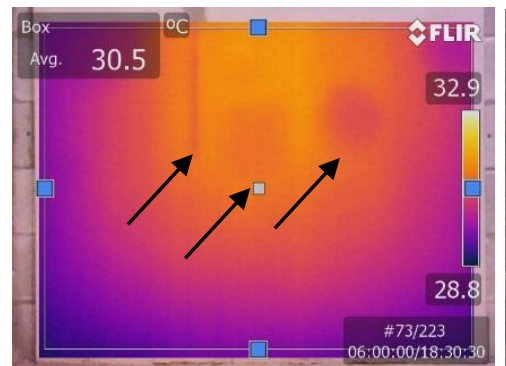

(a)

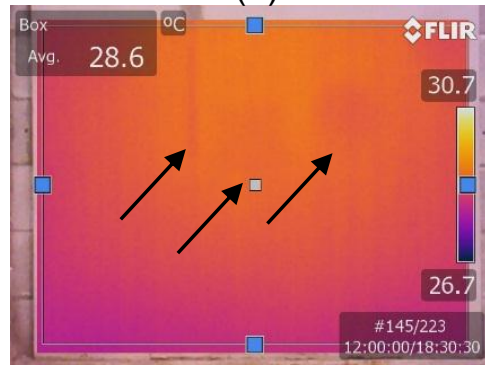

(d)

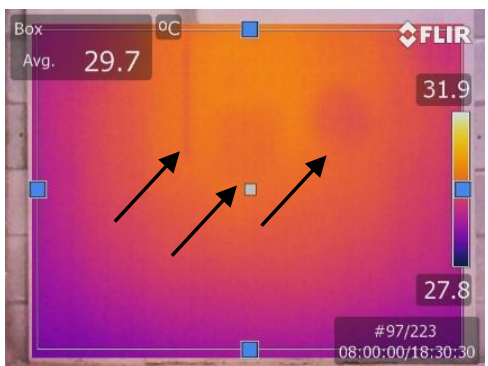

(b)

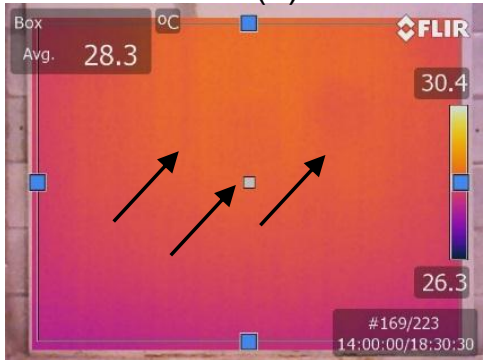

(e)

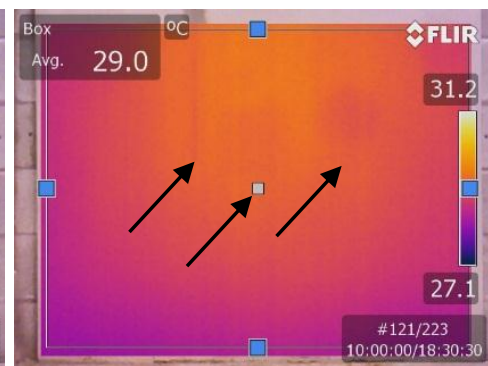

(c)

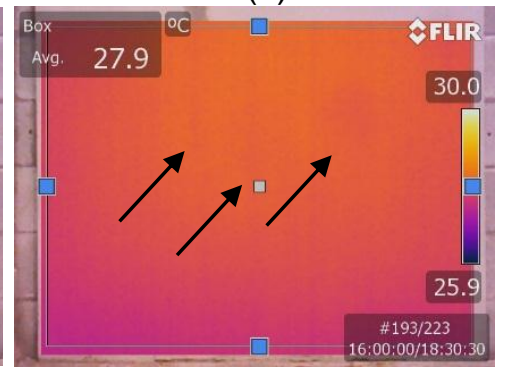

(f)

Figura 83. Termograma do painel PCO2-A após início do resfriamento: (a) Seis horas após; (b) Oito horas após; (c) Dez horas após; (d) Doze horas após; (e) Quatorze horas após; (f) Dezesseis horas após. (Fonte: Elaborado pelo autor). 
Comparativamente, para o painel PCO2-A (Figura 84) e PCO2-B cuja alvenaria por trás do reboco é em bloco de concreto as observações são as mesmas em relação ao painel PCE2-A.

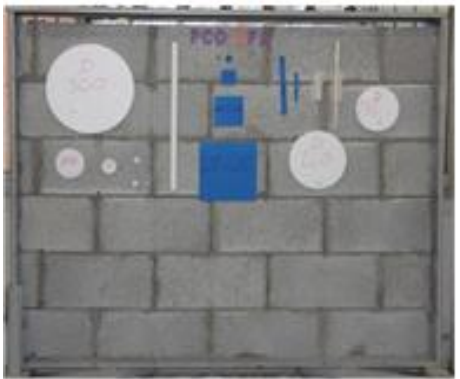

(a)

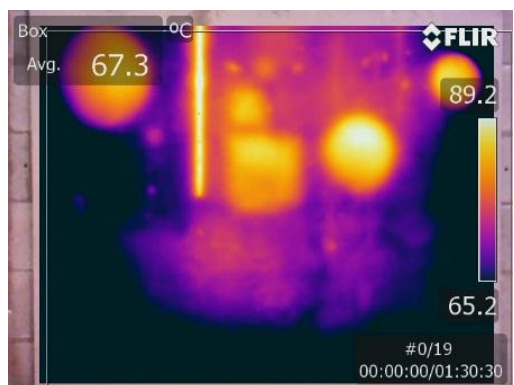

(b)

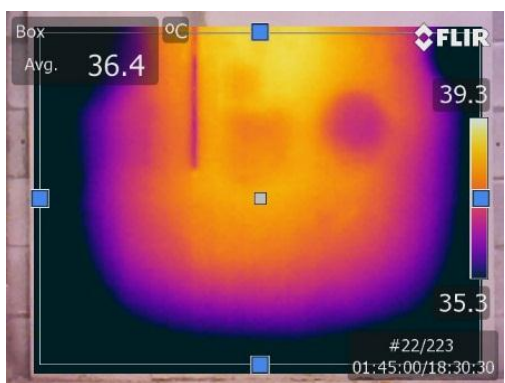

(c)

Figura 84. (a) Defeitos sob o reboco no painel PCO2-A (b) Termograma do painel PCO2-A logo após aquecimento; (c) Termograma do painel PCO2-A durante resfriamento. (Fonte: Elaborado pelo autor).

No resfriamento forçado com água através do uso do painel de resfriamento foram observados os seguintes padrões de comportamento nos termogramas:

- imediatamente após o resfriamento forçado não é possível identificar os defeitos (Figura 85-a e Figura 85-b).

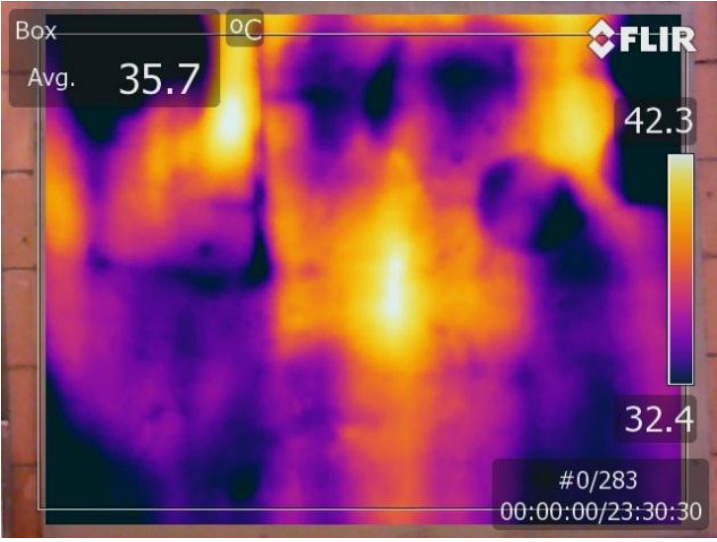

(a)

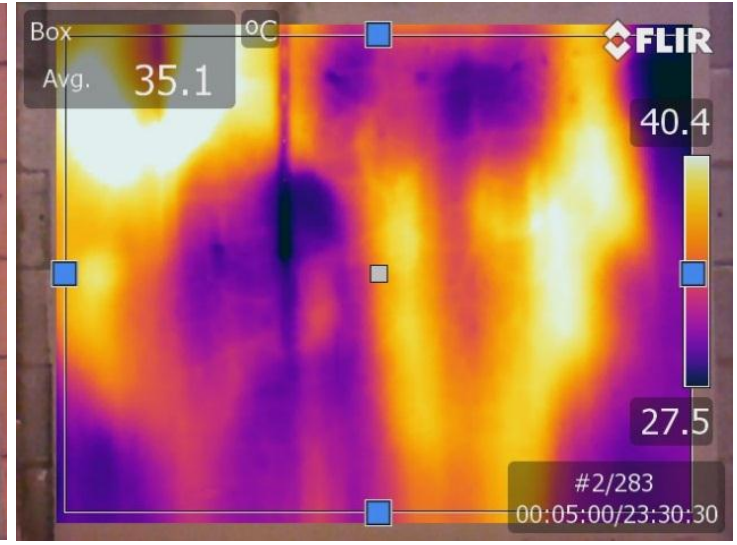

(b)

Figura 85. (a) Termograma do painel PCE2-A imediatamente após resfriamento forçado com água: (b) Termograma do painel PCO2-A imediatamente após resfriamento forçado com água. (Fonte: Elaborado pelo autor).

- passados os primeiros minutos de resfriamento forçado:

- no painel PCE2-A (Figura 86-a), a partir de 15 minutos foi possível identificar com clareza a localização e a forma dos defeitos, e no painel PCO2-A (Figura 86-b) apenas a partir de 40 minutos; 
- em comparação com o resfriamento ambiente, a visualização dos defeitos já inicia com uma temperatura mais baixa que as áreas de não defeitos (retânculos brancos na Figura 86);

- assim como observado no resfriamento ambiente, os defeitos são visualmente menos intensos que o momento imediatamente após o aquecimento destacando-se menos em relação às áreas de não defeitos similar ao observado no resfriamento natural;

- as bordas dos defeitos mantêm-se menos definidas em relação ao resfriamento natural em razão da maior dispersão térmica prejudicando a identificação da forma/dimensão do defeito;

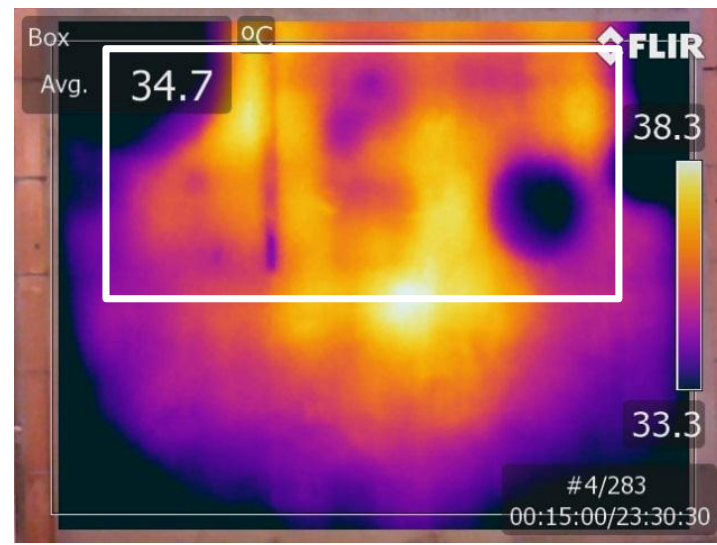

(a)

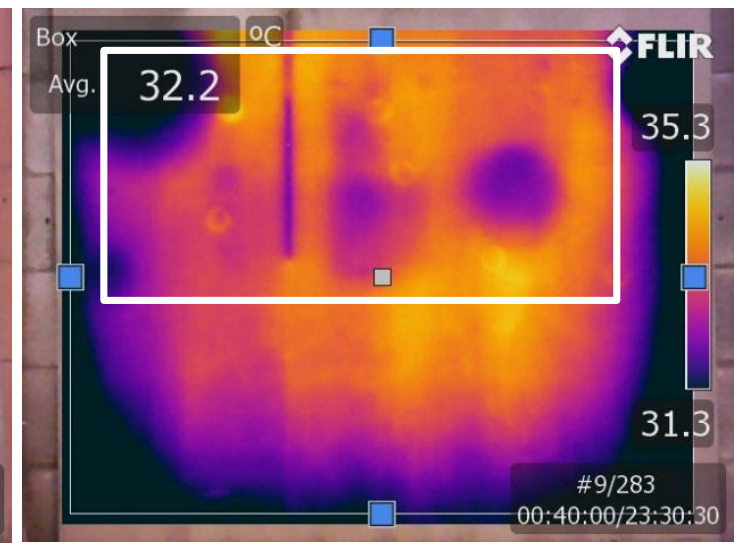

(b)

Figura 86. (a) Termograma do painel PCE2-A quinze minutos após resfriar com água: (b) Termograma do painel PCO2-A quarenta minutos após resfriar com água. (Fonte: Elaborado pelo autor).

- com o resfriamento forçado com água foi possível observar com precisão superior ao resfriamento ambiente a forma e a posição dos defeitos quadrados e circulares de dimensões até $50 \mathrm{~mm}$ feitos de EVA e isopor, respectivamente (destacados em vermelho na Figura 87-a), e o defeito cilíndrico de silicone com dimensões de $20 \mathrm{~mm}$ de diâmetro por $500 \mathrm{~mm}$ de comprimento, este último a $5 \mathrm{~mm}$ da superfície do reboco (seta preta na Figura 87-a), sendo essa visualização a mesma observada na condição logo após o resfriamento, ou seja, melhor que a condição após os primeiros minutos de resfriamento ambiente em que os defeitos quadrados e circulares de $50 \mathrm{~mm}$ feitos de EVA e isopor e o defeito esférico com diâmetro de $20 \mathrm{~mm}$ de isopor foram visualizados apenas levemente; 
- assim como na condição observada minutos após o resfriamento ambiente, as "manchas térmicas" diminuem bastante até desaparecerem por completo à medida que o resfrimennto avança fazendo com que o defeito esférico de isopor com diâmetro de $20 \mathrm{~mm}$ apesar de ser identificado levemente (seta branca na Figura 87-a) não seja confundido com as manchas, ao contrário do observado na condição logo após o aquecimento;

- devido à proximidade de $5 \mathrm{~mm}$ da superfície, assim como os defeitos retângulares de $10 \times 100 / 20 \times 200$ e cilindros de $10 \times 100 / 10 \times 300$ feitos de EVA e madeira, respectivamente (retângulo preto na Figura 87-b) serem visualizados levemente, podem ser facilmente confundidos com "manchas térmicas" causadas por condições variadas das superfície do reboco, como imperfeições de acabamento, diferenças de rugosidade da argamassa, áreas com diferentes tonalidades da própria argamassa (Figura 87-a);

- assim como observado na condição após os primeiros minutos de resfriamento ambiente, no resfriamento forçado também passam a não serem mais visíveis os defeitos quadrados e circulares de $20 \mathrm{~mm}$ feitos de EVA e isopor, respectivamente (setas azuis na Figura 87-b), esfera de isopor de10 mm (seta verde na Figura 87-b), os defeitos retangulares de $10 \times 100 / 20 \times 200$ e cilindros de $10 \times 100 / 10 \times 300$ feitos de EVA e madeira, respectivamente (retângulo preto na Figura 87-b), antes visíveis no momento imediatamente após o aquecimento. 


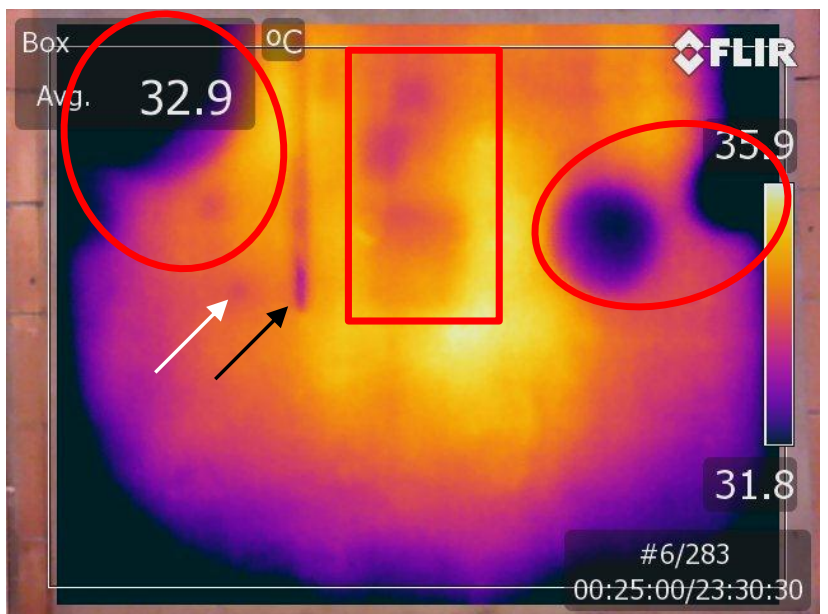

(a)

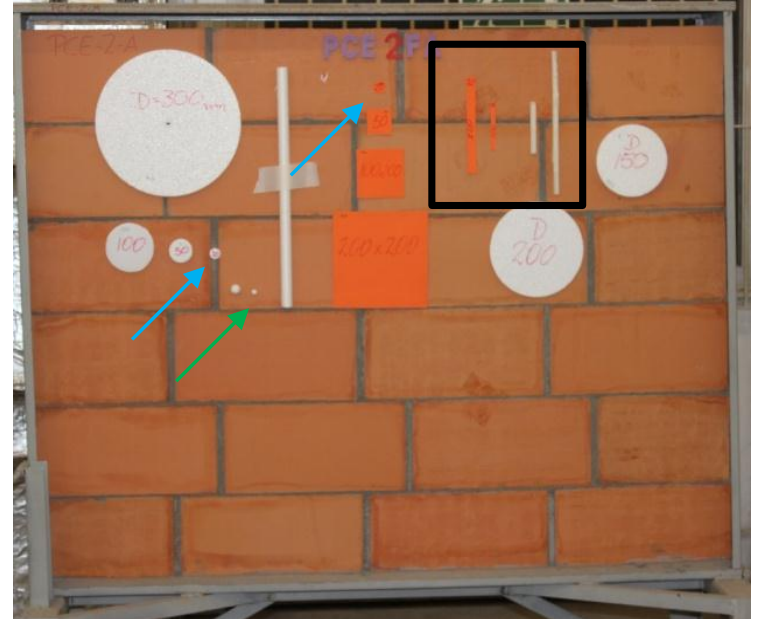

(b)

Figura 87. (a) Termograma do painel PCE2-A 25 minutos após resfriamento forçado com água: (b) Defeitos sob o reboco no painel PCE2-A. (Fonte: Elaborado pelo autor).

No painel PCO2-A, a melhor condição para observação dos defeitos ocorreu 45 minutos após o resfriamento forçado e, em comparação ao observado no painel PCE2-A, a única diferença é a inclusão do defeito quadrado de $50 \mathrm{~mm}$ (seta branca na Figura 88-a e b) na lista dos defeitos não visíveis.

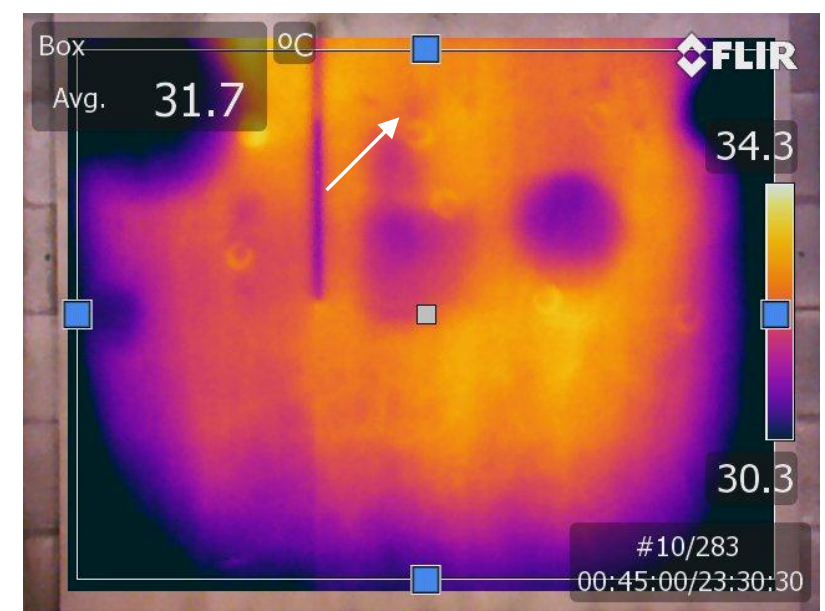

(a)

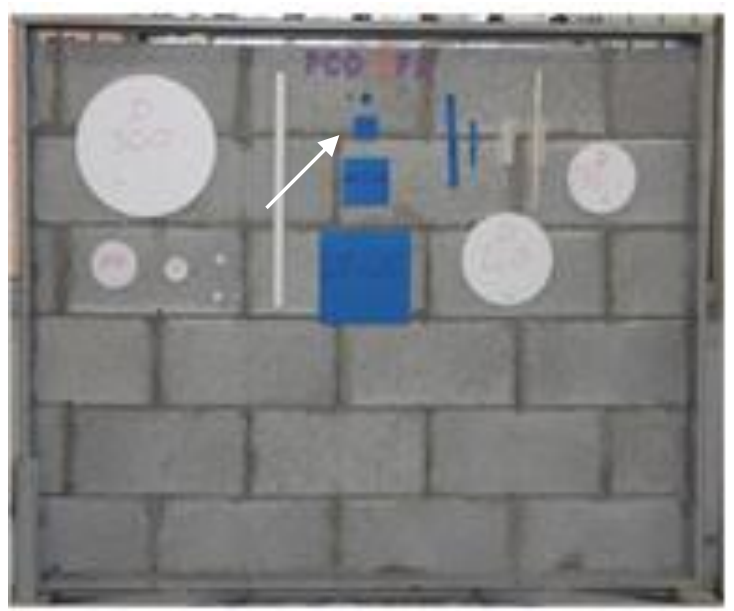

(b)

Figura 88. (a) Termograma do painel PCO2-A 45 minutos após resfriamento forçado com água: (b) Defeitos sob o reboco no painel PCO2-A. (Fonte: Elaborado pelo autor).

- passadas as primeiras horas de resfriamento forçado:

- a partir da quarta hora de resfriamento há uma perda da forma e dimensão dos defeitos dificultando/inviabilizando gradativamente sua identificação. Sendo assim, a visualização dos defeitos permanece por 
menos tempo em comparação com a condição de resfriamento ambiente (Figura 89 e Figura 90).

- em função da espessura do revestimento de argamassa sobre o defeito de desplacamento, o tempo de visualização dos defeitos mais profundos (setas pretas na Figura 89) é menor que os defeitos mais próximos da superfície (setas brancas na Figura 89 e Figura 90), pois, apesar de o defeito mais profundo ter aquecido menos que o mais superfícial, ele resfria mais lentamente, podendo inviabilizar a diferenciação pelo requisito espessura em idades mais avançadas do resfriamento.

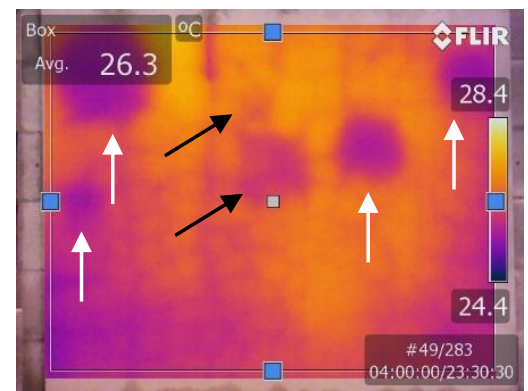

(a)

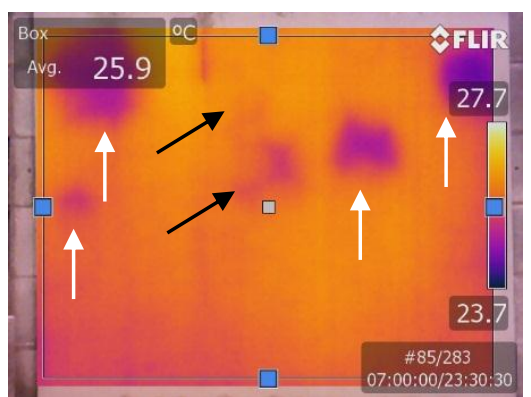

(d)

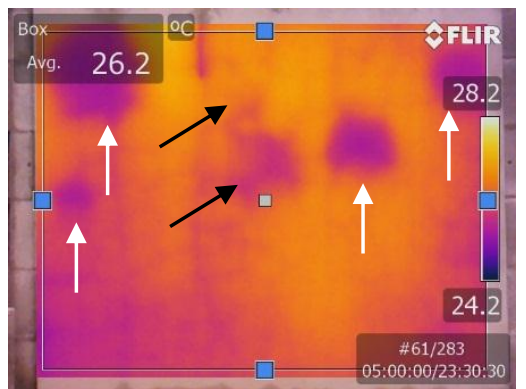

(b)

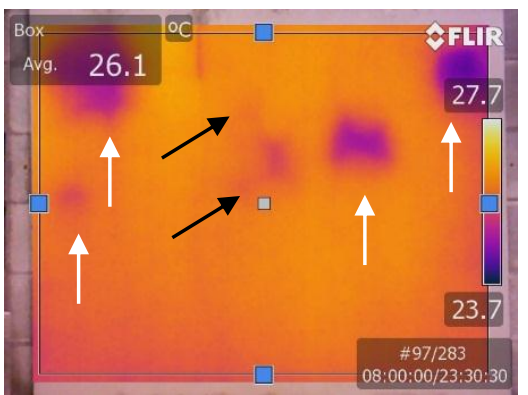

(e)

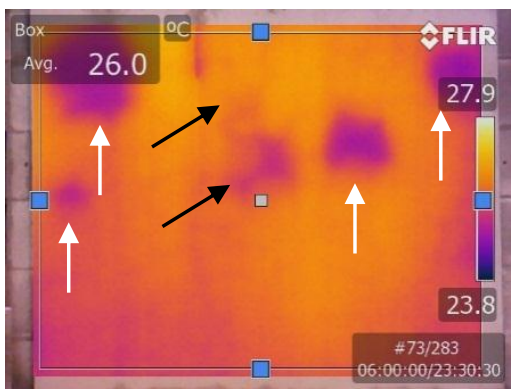

(c)

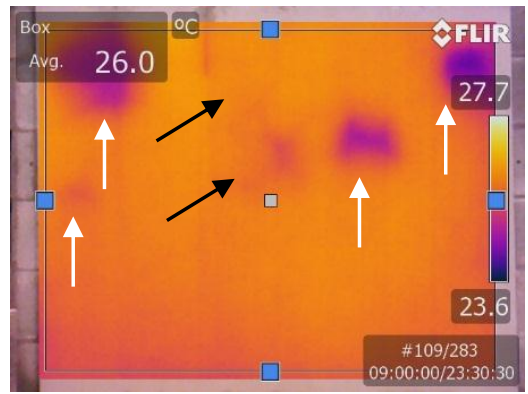

(f)

Figura 89. Termograma do painel PCO2-A após início do resfriamento forçado: (a) quatro horas após; (b) cinco horas após; (c) seis horas após; (d) sete horas após; (e) oito horas após; (f) nove horas após. (Fonte: Elaborado pelo autor). 


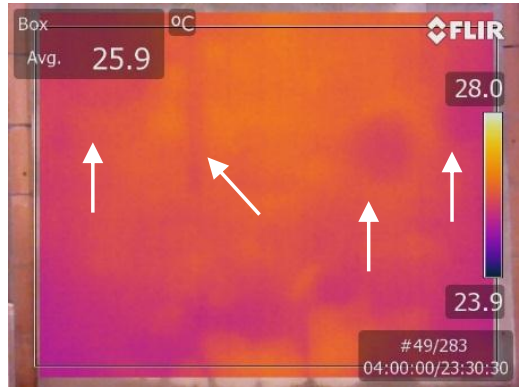

(a)

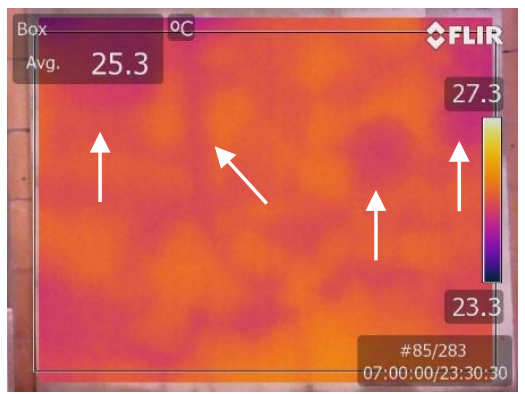

(d)

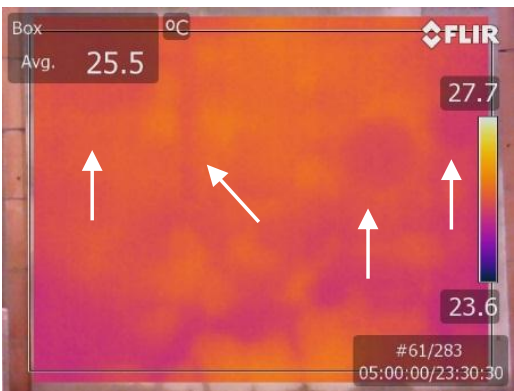

(b)

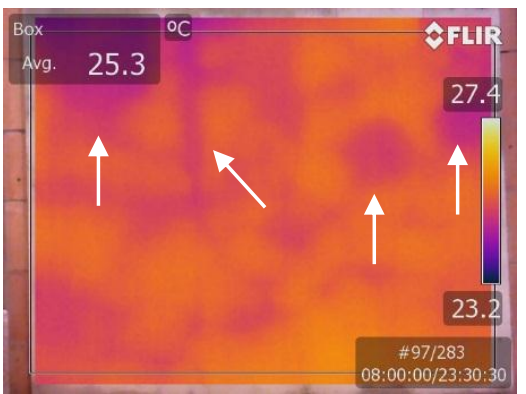

(e)

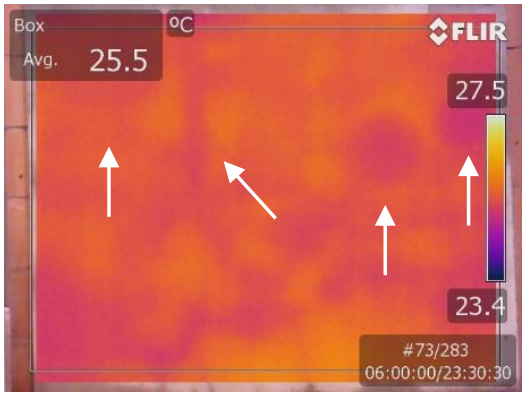

(c)

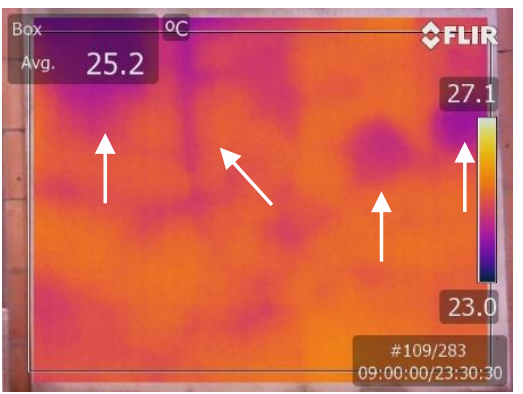

(f)

Figura 90. Termograma do painel PCE2-A após início do resfriamento forçado: (a) quatro horas após; (b) cinco horas após; (c) seis horas após; (d) sete horas após; (e) oito horas após; (f) nove horas após. (Fonte: Elaborado pelo autor).

\section{- Campo}

No aquecimento ao sol foram observados os seguintes padrões de comportamento nos termogramas do painel PCE2-A:

- os defeitos apresentam-se com temperaturas superiores às áreas de não defeitos durante todo o período de aquecimento;

- imediatamente após o posicionamento do painel ao sol na área externa do laboratório foi possível identificar defeitos mais próximos à superfície do reboco com um leve contraste térmico em relação às áreas de não defeitos, com precisão de forma e localização. São eles os círculos de isopor com diâmetros de 300, 200 e $150 \mathrm{~mm}$ a $15 \mathrm{~mm}$ da superfície do reboco (setas brancas na Figura 91-a) e o defeito cilíndrico de silicone com dimensões de $20 \mathrm{~mm}$ de diâmetro por $500 \mathrm{~mm}$ de comprimento, este último com um contraste térmico devido à maior proximidade $(5 \mathrm{~mm})$ da superfície do reboco (seta preta na Figura 91-a);

- passados cinco minutos de exposição ao sol já se tornaram visíveis quanto à forma e à localização os defeitos circulares de 100 e 50 mm de diâmetro 
(setas brancas na Figura 91-c), e a esfera de $20 \mathrm{~mm}$ de diâmetro (seta vermelha na Figura 91-c) e o defeito quadrado de $200 \mathrm{~mm}$ de lado começam a ter seus limites estabelecidos no termograma (seta preta na Figura 91-c), posicionados, respectivamente, a $20 \mathrm{~mm}, 5 \mathrm{~mm}$ e $23 \mathrm{~mm}$ de profundidade em relação à superfície do reboco e ao contraste térmico. Já os defeitos circulares de isopor com diâmetros de 300, 200 e 150 mm tornam-se bastante destoantes, com diferenças de temperatura em relação às áreas de não defeitos;

- nos termogramas registrados entre 10 e 30 minutos do início do aquecimento houve um aumento do contraste térmico entre defeitos já identificados e as áreas de não defeitos (Figura 92-a e Figura 92-b respectivamente), porém não foram visualizados novos defeitos com clareza de forma e posição;

○ com a evolução do aquecimento (60, 120 e 180 minutos):

- observa-se a interferência térmica crescente da alvenaria em tijolo cerâmico na superfície do reboco, sendo possível distinguir as juntas de assentamento da alvenaria (setas brancas na Figura 93-b) dos tijolos (setas pretas na Figura 93-b);

- com a redução do gradiente térmico entre as regiões com e sem defeitos e o aumento da influência térmica da alvenaria no termograma, o defeito mais profunto (quadrado de $200 \mathrm{~mm}$ de lado em EVA) e os menores mais rasos (círculo de $50 \mathrm{~mm}$ de diâmetro e esfera de $20 \mathrm{~mm}$ de diâmetro), anteriormente bem identificados, começam a perder a definição de forma e passam a ser facilmente confundidos (seta branca e setas pretas respectivamente na Figura 93-a);

- os defeitos maiores e próximos à superfície (círculos de isopor com diâmetros de 300, 200, 150 e 100 mm e cilindro de 20 x 500 mm) mantêmse em destaque em relação às áreas sem defeitos (Figura 93-c).

- defeitos não visíveis: quadrados de 100, 50 e 20 mm de lado em EVA (retângulo preto na Figura 91-b), círculo de $20 \mathrm{~mm}$ feitos de isopor (seta branca na Figura 91-b), esfera de isopor de $10 \mathrm{~mm}$ (seta preta na Figura 91b), os defeitos retangulares de $10 \times 100 / 20 \times 200$ e cilindros de $10 \times 100 /$ 
$10 \times 300$ feitos de EVA e madeira, respectivamente (retângulo branco na Figura 91-b).

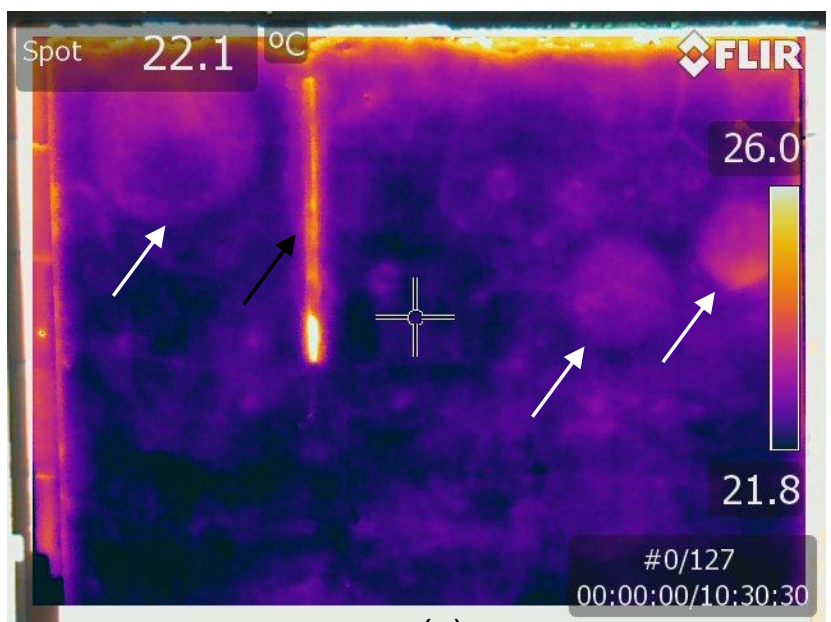

(a)

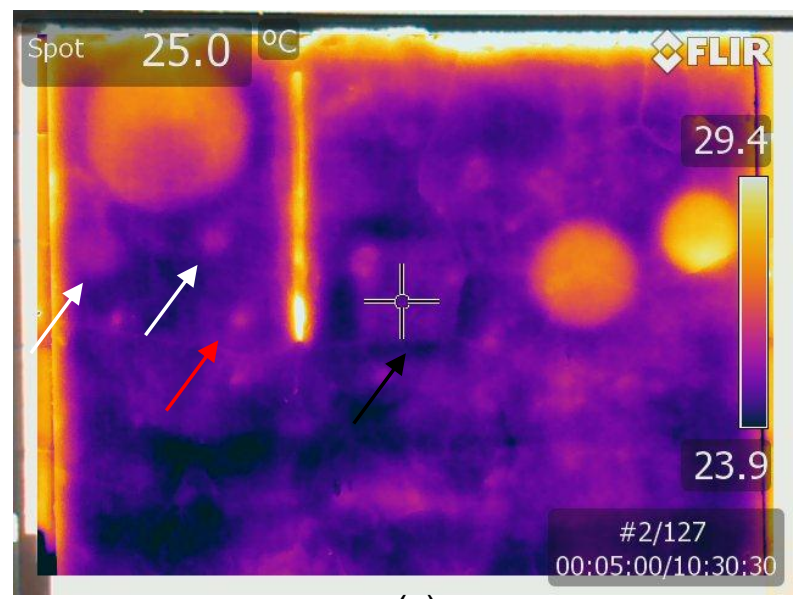

(c)

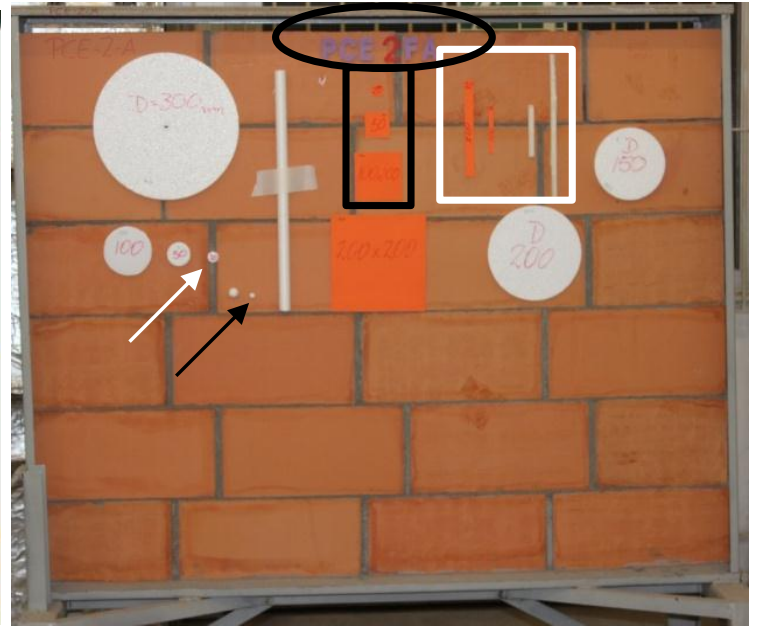

(b)

Figura 91. (a) Termogramas do painel PCE2-A no início do aquecimento ao sol; (b) Defeitos sob o reboco no painel PCE2-A; (c) Termogramas do painel PCE2-A 5 minutos após o início do aquecimento ao sol. (Fonte: Elaborado pelo autor).

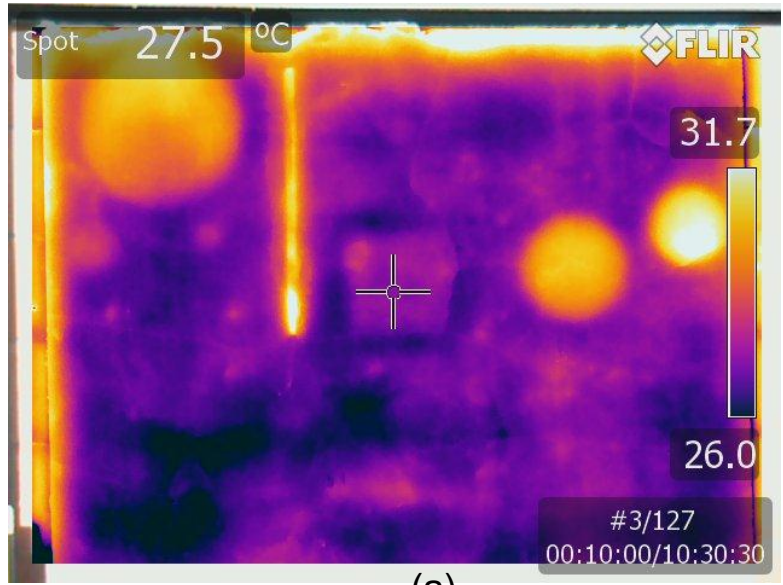

(a)

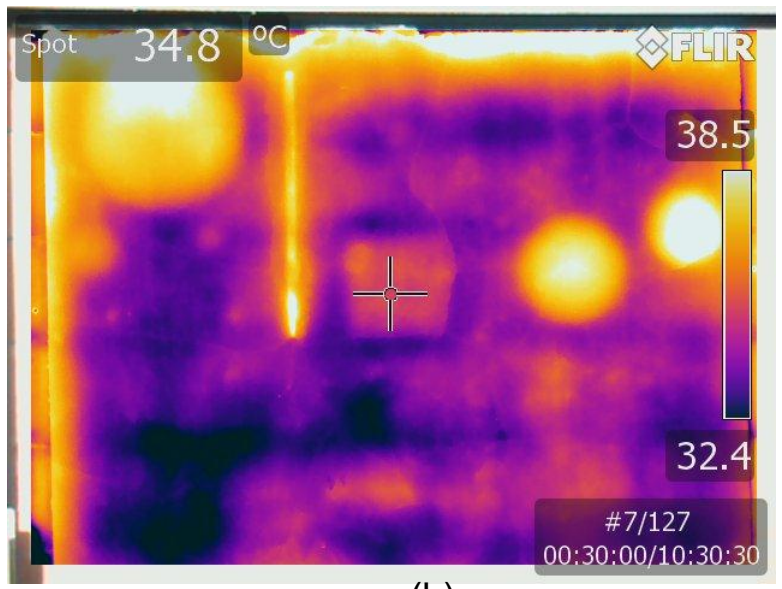

(b)

Figura 92. Termogramas do painel PCE2-A após o início do aquecimento ao sol: (a) 10 minutos após; (b) 30 minutos após. (Fonte: Elaborado pelo autor). 


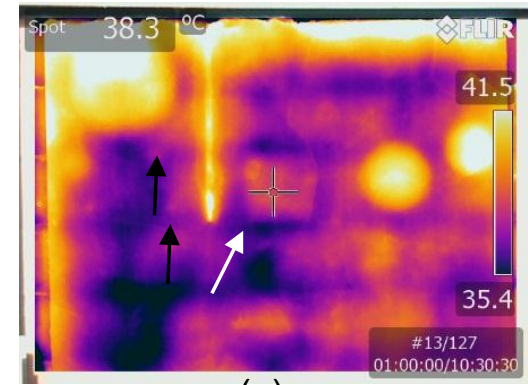

(a)

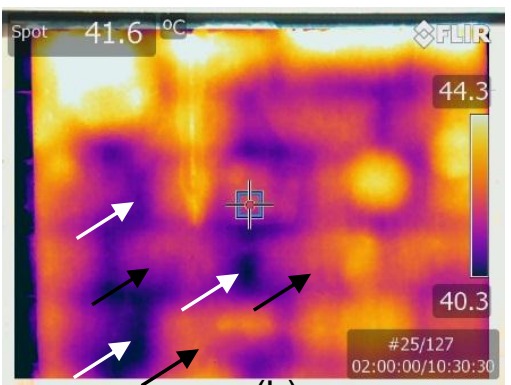

(b)

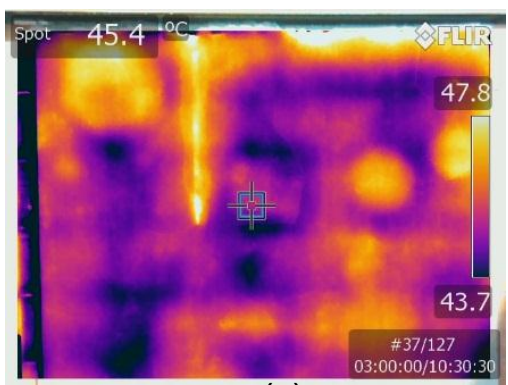

(c)

Figura 93. Termogramas do painel PCE2-A após o início do aquecimento ao sol: (a) 60 minutos após; (b) 120 minutos após; (c) 180 minutos após. (Fonte: Elaborado pelo autor).

Para o painel PCO2-A, foram observadas mudanças representativas de comportamento em comparação com o painel PCE2-A:

- imediatamente após o posicionamento do painel ao sol na área externa do laboratório, além dos defeitos identificados no painel PCE2-A também foi possível identificar claramente os círculos de isopor com diâmetros de 300, 220, 150 e $100 \mathrm{~mm}$ posicionados a $20 \mathrm{~mm}$ da superfície do reboco (seta branca na Figura 94-a), os quadrados de 200, 100 e 50 mm (retângulo preto na Figura 94-a) a $23 \mathrm{~mm}$ da superfície, sendo os dois últimos ainda sem uma definição clara das bordas; e de maneira pouco perceptível o círculo de 50 $\mathrm{mm}$ (seta preta na Figura 94-a) e a esfera de $20 \mathrm{~mm}$ de diâmetro de isopor (seta vermelha na Figura 94-a);

- passados cinco minutos de exposição ao sol (Figura 94-c) os defeitos identifcados se tornaram mais visíveis e com melhor definição de bordas com diferenças de temperatura em relação às áreas de não defeitos, porém não foram visualizados novos defeitos;

- nos termogramas registrados entre 10 e 30 minutos do início do aquecimento, além do aumento do contraste térmico entre defeitos já identificados e as áreas de não defeitos (Figura 95), as letras "PCE2FA" em EVA no alto do painel (elipse preta na Figura 95-b) passam a ser identificadas apenas como uma mancha com diferenças de temperatura em relação à área de não defeito em volta;

- com a evolução do aquecimento (60 minutos):

- também observa-se a interferência térmica da alvenaria em bloco de concreto na superfície do reboco, porém não sendo possível distinguir as 
juntas de assentamento da alvenaria (setas brancas na Figura 96-a e Figura 96-b) do travamento interno do bloco (setas pretas na Figura 96-a, Figura 96-b e Figura 96-c);

- mesmo com a interferência da alvenaria mantém-se um bom contraste térmico entre todos os defeitos já observados com boa definição de forma e localização;

- não são percebidos novos defeitos.

- defeitos não visíveis: quadrados de $20 \mathrm{~mm}$ de lado em EVA (seta vermelha na Figura 94-b), círculo de $20 \mathrm{~mm}$ feitos de isopor (seta branca na Figura 94b), esfera de isopor de $10 \mathrm{~mm}$ (seta preta na Figura 94-b), os defeitos retangulares de $10 \times 100 / 20 \times 200$ e cilindros de $10 \times 100 / 10 \times 300$ feitos de EVA e madeira, respectivamente (retângulo branco na Figura 94-b);

- é possível observar a interferência térmica do tijolo cerâmico.

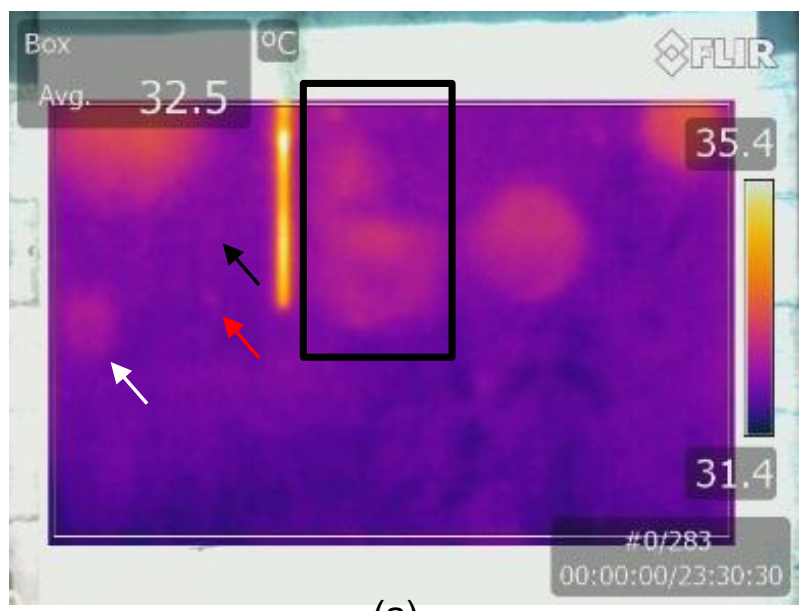

(a)

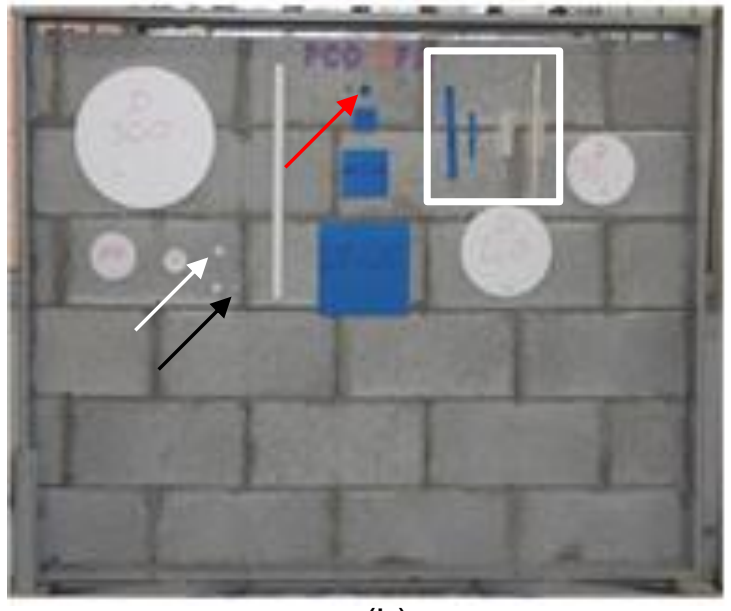

(b)

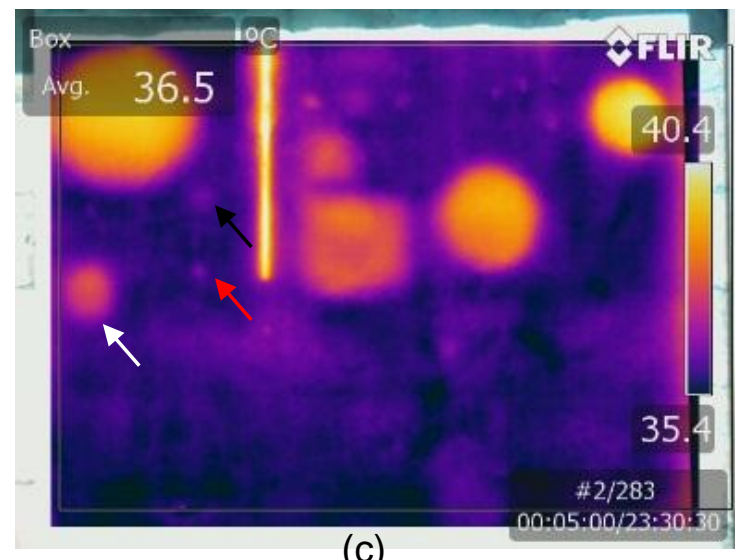

(c)

Figura 94. (a) Termogramas do painel PCO2-A no início do aquecimento ao sol; (b) Defeitos sob o reboco no painel PCO2-A; (c) Termogramas do painel PCO2-A 5 minutos após o início do aquecimento ao sol. (Fonte: Elaborado pelo autor). 


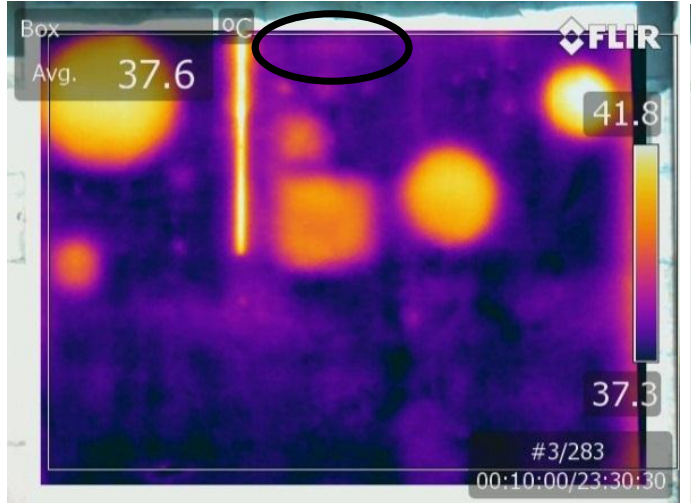

(a)

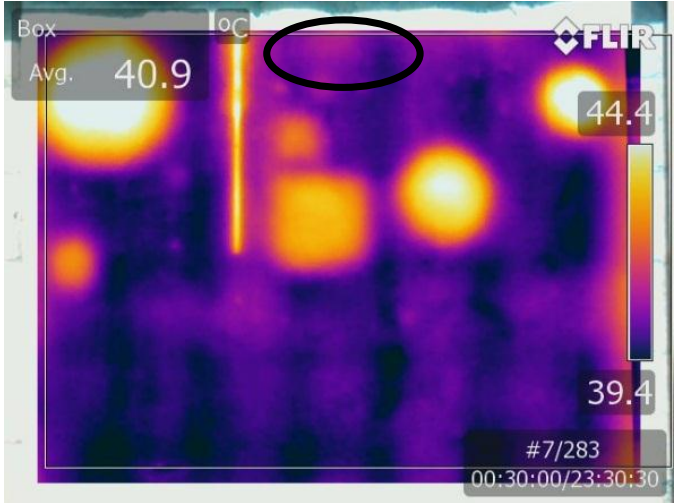

(b)

Figura 95. Termogramas do painel PCO2-A após o início do aquecimento ao sol: (a) 10 minutos após; (b) 30 minutos após. (Fonte: Elaborado pelo autor).

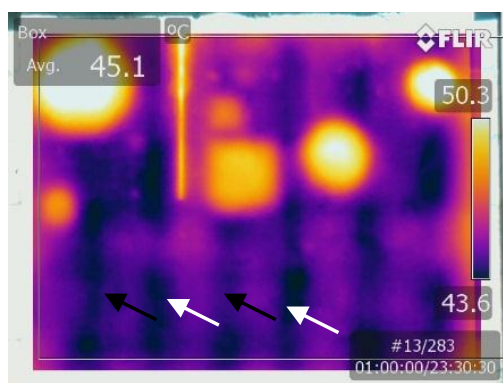

(a)

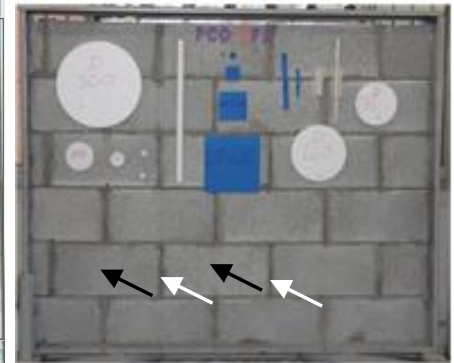

(b)

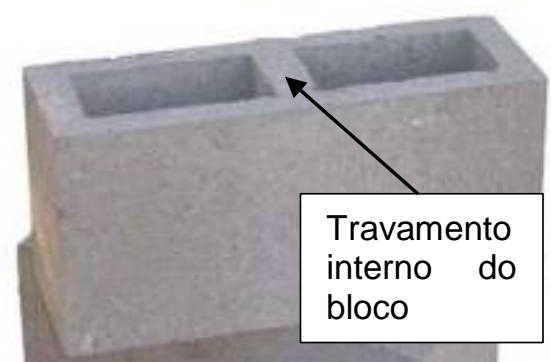

(c)

Figura 96. Termogramas do painel PCO2-A após o início do aquecimento ao sol: (a) 60 minutos após; (b) Defeitos sob o reboco no painel PCO2-A; (c) Travamento interno do bloco. (Fonte: Elaborado pelo autor).

A etapa de resfriamento à sombra no painel PCO2-A iniciou 15 minutos antes de finalizar os 180 minutos de aquecimento devido à presença de nuvens que encobriram o sol:

- no termograma registrado 15 minutos após o início do resfriamento, o defeito quadrado de $50 \mathrm{~mm}$, circular de $50 \mathrm{~mm}$ e esférico de $20 \mathrm{~mm}$ representado pelas setas brancas na Figura 97-a ficam não visíveis para o gradiente térmico entre as áreas de defeito e não defeito (setas brancas na Figura 97c) retornando após a inversão térmica (defeitos mais frios em relação às áreas de não defeitos);

- nos demais defeitos a inversão térmica ocorre no intervalo entre um termograma e outro (5 minutos). Sendo o defeito cilíndrico de silicone de 20 $\mathrm{mm}$ de diâmetro por $500 \mathrm{~mm}$ de comprimento cinco minutos após o início do resfriamento (Figura 97-b), círculo de isopor de $150 \mathrm{~mm}$ de diâmetro e quadrado de $50 \mathrm{~mm}$ de lado após 25 minutos (Figura 97-d), círculo de 300 e $100 \mathrm{~mm}$ e quadrado de $100 \mathrm{~mm}$ após 35 minutos (Figura 97-e), círculo de 
$200 \mathrm{~mm}$ após 40 minutos (Figura 97-f) e quadrado de $200 \mathrm{~mm}$ de lado mais círculo de 50 mm de diâmetro após 45 minutos (Figura 97-g);

- após a inversão térmica os defeitos mais profundos são visualmente menos intensos (retângulo branco da Figura 97-h) se destacando menos em relação às áreas de não defeitos quando comparado com os defeitos mais próximos à superfície do reboco;

- todos os defeitos visualizados durante o aquecimento também o são durante o resfriamento e a interferência da alvenaria e menor que a observada durante $o$ aquecimento;

- pelas mesmas razões observadas na etapa de laboratório, o tempo de visualização do defeito (setas pretas na Figura 97-i) é praticamente o mesmo para diferentes espessuras de reboco.

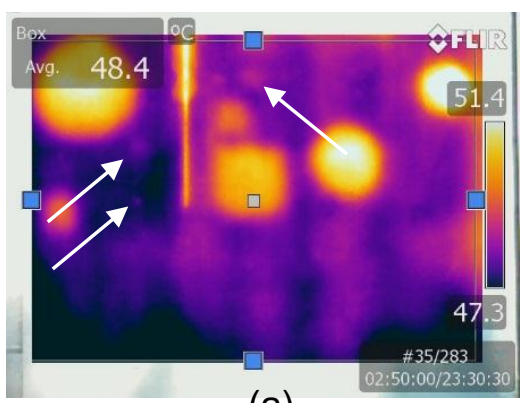

(a)

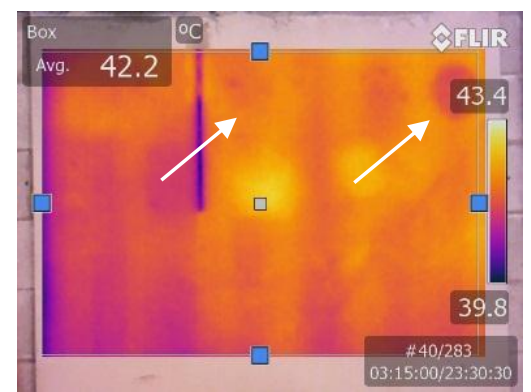

(d)

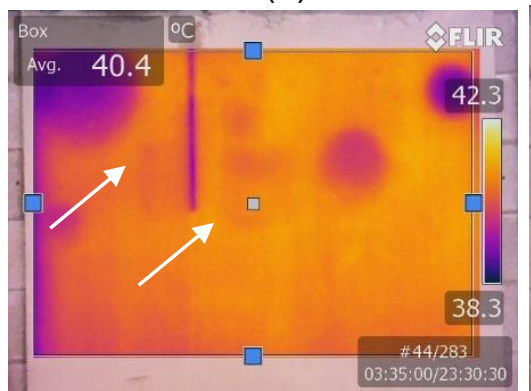

(g)

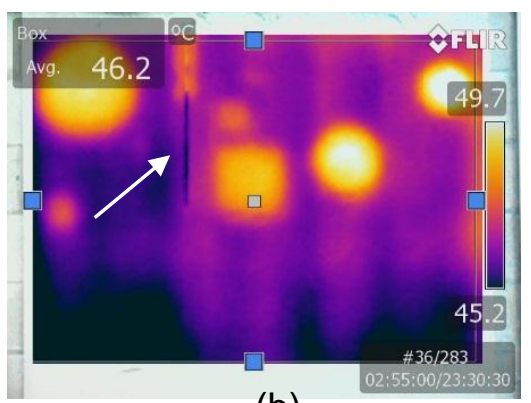

(b)

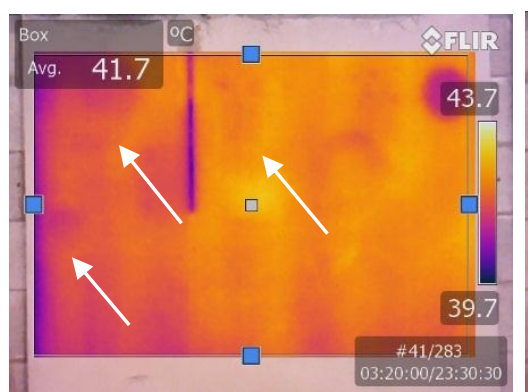

(e)

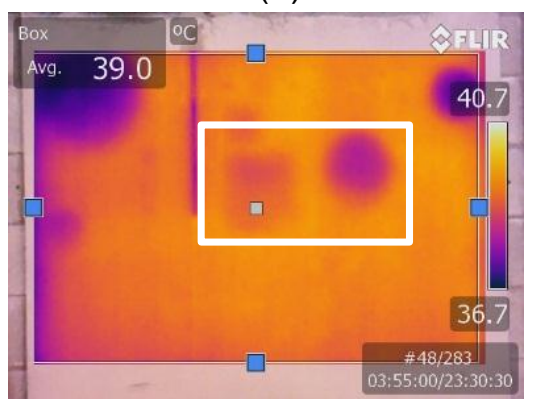

(h)

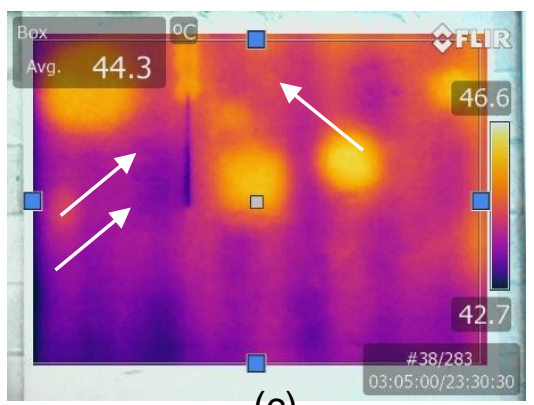

(c)

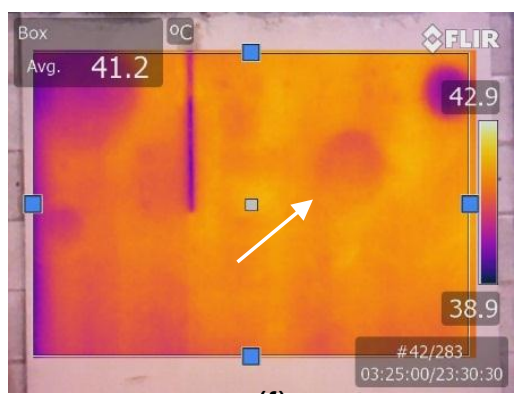

(f)

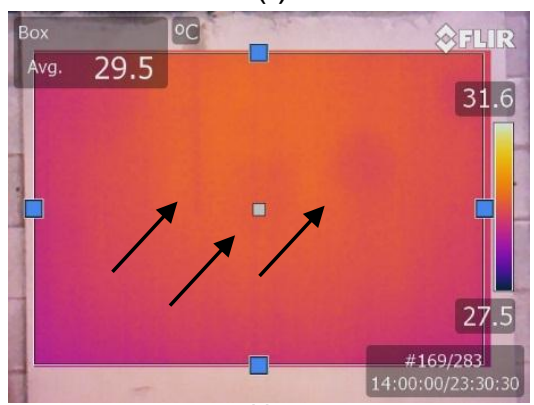

(i)

Figura 97. Termograma do painel PCO2-A após início do resfriamento: (a) Imediatamente após; (b) Cinco minutos após; (c) Quinze minutos após; (d) 25 minutos após; (e) trinta minutos após; (f) 35 minutos após; (g) 45 minutos após; (h) 65 minutos após; (i) Quatorze horas e dez minutos após. (Fonte: Elaborado pelo autor). 
Para o painel PCE2-A o período de resfriamento foi marcado por poucas diferenças em relação ao painel PCE2-A:

- nos primeiros 20 minutos de resfriamento há uma interferência térmica decrescente da alvenaria na superfície do reboco, a ponto de dificultar/inviabilizar a identificação da maior parte dos defeitos. Na Figura 98-b (cinco minutos após o início do resfriamento) apenas os defeitos sinalizados com setas brancas são identificáveis, porém, em uma situação de desconhecimento prévio dos defeitos, eles seriam facilmente confundidos com exceção do cilindro de 20 x 500 mm que já sofreu a inversão térmica;

- após 15 minutos de resfriamento (Figura 98-c) os defeitos circulares de 300, 200 e 150 mm de diâmetro também sofrem a inversão térmica e melhoram sua visualização;

- com quarenta minutos de resfriamento os defeitos quadrados de 200, 100 e 50 mm de lado (retângulo branco na Figura 98-d), assim como os círculos de 100 e $50 \mathrm{~mm}$, este último de forma quase imperceptível (setas branca e preta respectivamente), tornam-se visíveis;

- comparando os termogramas registrados cinco e sete horas após o início do resfriamento, Figura 98-e e Figura 98-f, respectivamente, os defeitos permanecem igualmente visíveis apesar da redução de temperatura do painel; isso porque a diferença de temperatura proporcional entre áreas com e sem defeito permanecem similares; 


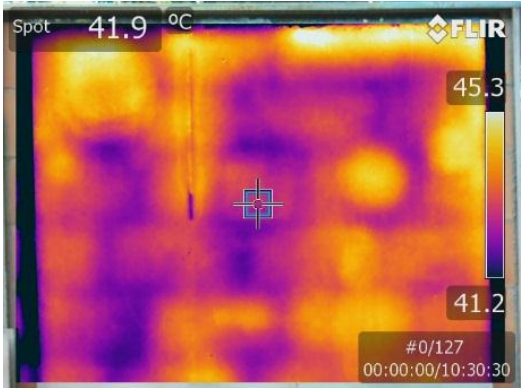

(a)

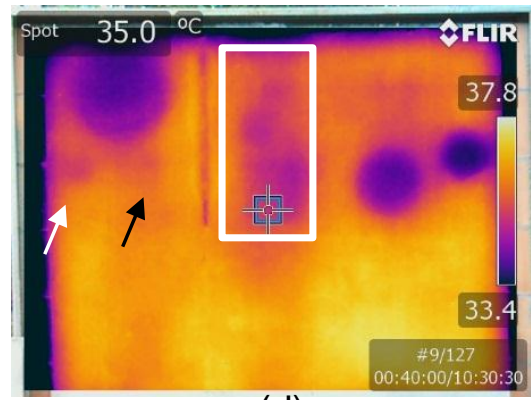

(d)

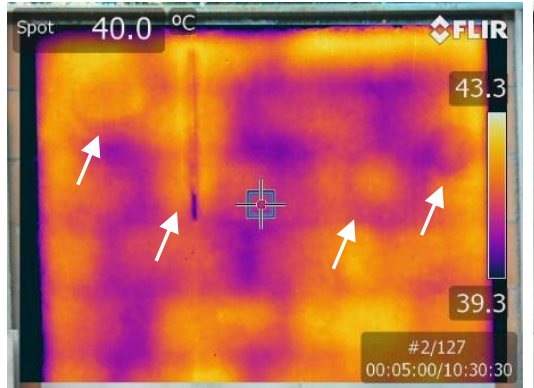

(b)

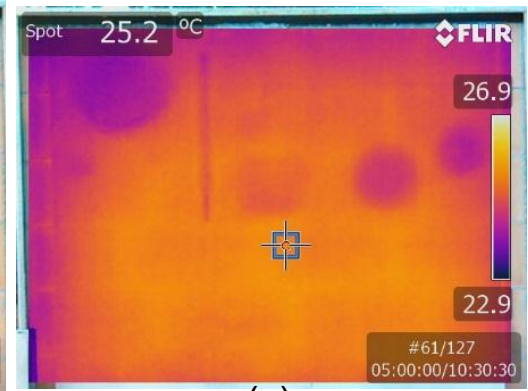

(e)

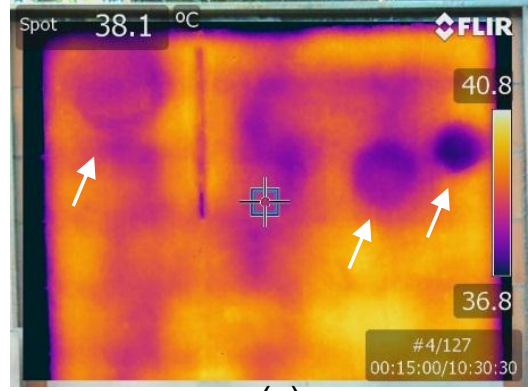

(c)

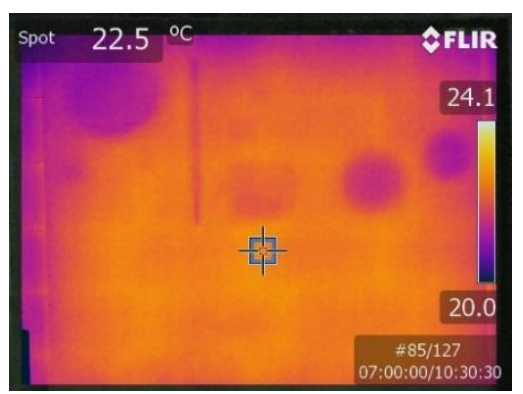

(f)

Figura 98. Termograma do painel PCE2-A após início do resfriamento: (a) imediatamente após; (b) cinco minutos após; (c) quinze minutos após; (d) quarenta minutos após; (e) cinco horas após; (f) sete horas após. (Fonte: Elaborado pelo autor).

Comparativamente, os termogramas gerados na etapa de campo (Figura 99-b) em relação aos gerados na etapa de laboratório (Figura 99-a) apresentaram as seguintes diferenças:

- mesmo com os procedimentos de isolamento das laterais e parte superior do painel com placas de drywall, papelão ou isopor, em todos os testes da etapa laboratório, a distribuição de temperatura sobre a superfície não foi uniforme e os pontos de medição selecionados não receberam exatamente a mesma quantidade da energia de radiação;

- na etapa de campo, a uniformidade na distribuição de radiação térmica sobre a superfície dos painéis pela incidência solar permitiu a mesma condição de visualização dos defeitos em toda a área do painel; 


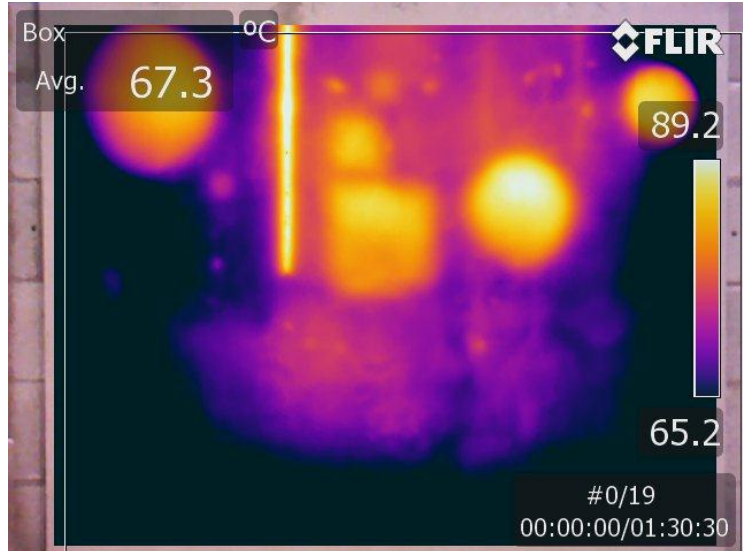

(a)

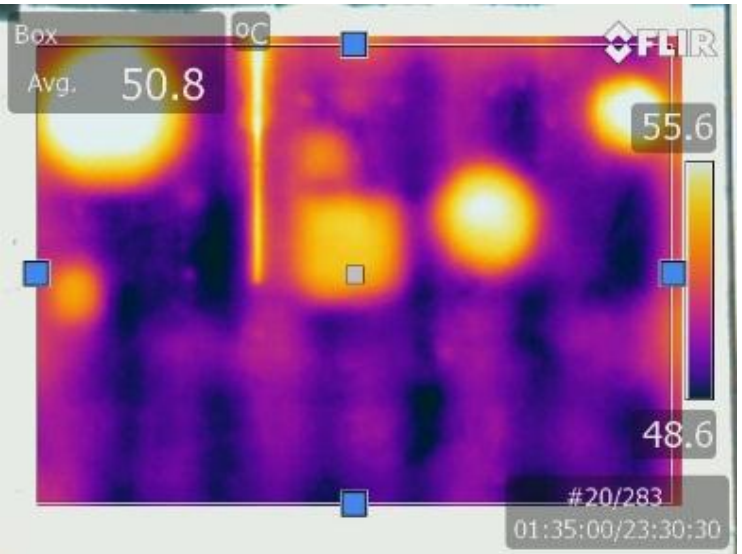

(b)

Figura 99. Termogramas do painel PCO2-A: (a) aquecimento através de painel térmico; (b) aquecimento através do sol. (Fonte: Elaborado pelo autor).

A análise dos termogramas para identificar defeitos de falhas de assentamento (vazios) sob revestimento cerâmico foi focada nas duas faces dos painéis PCE3 e PCO3, seguindo as mesmas condições e considerações utilizadas com os painéis PCE2 e PCO2.

\section{- Laboratório}

No resfriamento à temperatura ambiente foram observados os seguintes padrões de comportamento nos termogramas:

- imediatamente após o aquecimento:

- áreas de descolamento apresentaram maiores valores de temperatura.

- foi possível observar nos painéis PCE3-B (Figura 100-a) e PCO3-A (Figura 101-a) a forma e a posição dos defeitos sob as cerâmicas com precisão: quadrados e circulares de $200 \mathrm{~mm}$ de lado e de diâmetro, respectivamente, ilustrados na Figura 100-b e Figura 101-b e os vazios circulares com 100 e $50 \mathrm{~mm}$ de diâmetro e quadrado de $50 \mathrm{~mm}$ de lado destacados nos retângulos brancos.

- os painéis PCE3-A (Figura 102-b) e PCO3-B (Figura 103-b), onde foram simulados vazios de argamassa para assentamento cerâmico (regiões sem a marcação com o "X" na Figura 102-a e Figura 103-a) apareceram com temperaturas maiores em relação às áreas de cerâmica com argamassa. Pontos de fixação com argamassa colante (setas vermelhas na Figura 102-a e Figura 103-a) ficaram bastante explícitos com temperaturas mais baixas que o seu entorno. 
- as superfícies cerâmicas mais escuras apresentaram as maiores temperaturas sobre a região dos defeitos em relação à cerâmica branca.

- o defeito simulando cordões de argamassa não esmagados durante o processo de aplicação da argamassa (setas vermelhas na Figura 100-b e Figura 101-b) foi visualizado como uma mancha, conforme destacado nos retângulos vermelhos na Figura 100-a e Figura 101-a.

- os defeitos simulados com os números de 0 a 8 em EVA (Figura 100-b) não eram visíveis conforme destacado nos retângulos brancos na Figura 100-a.

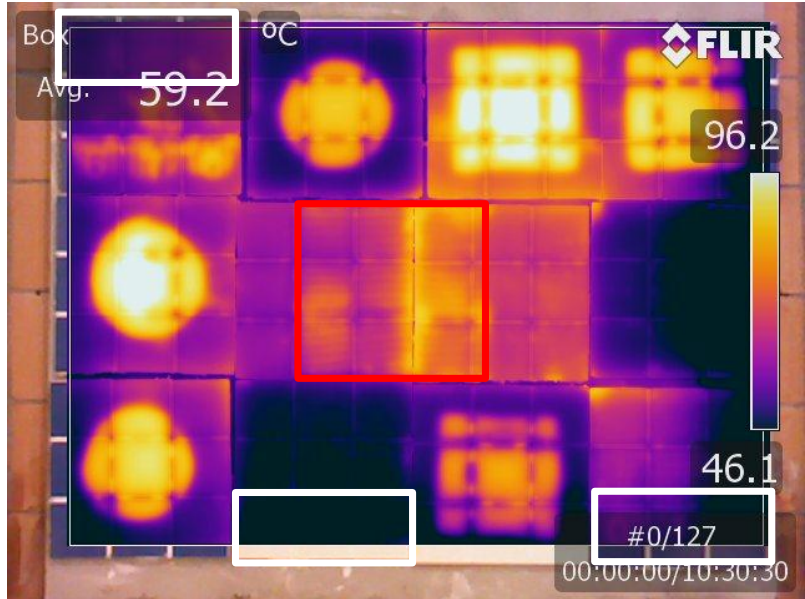

(a)

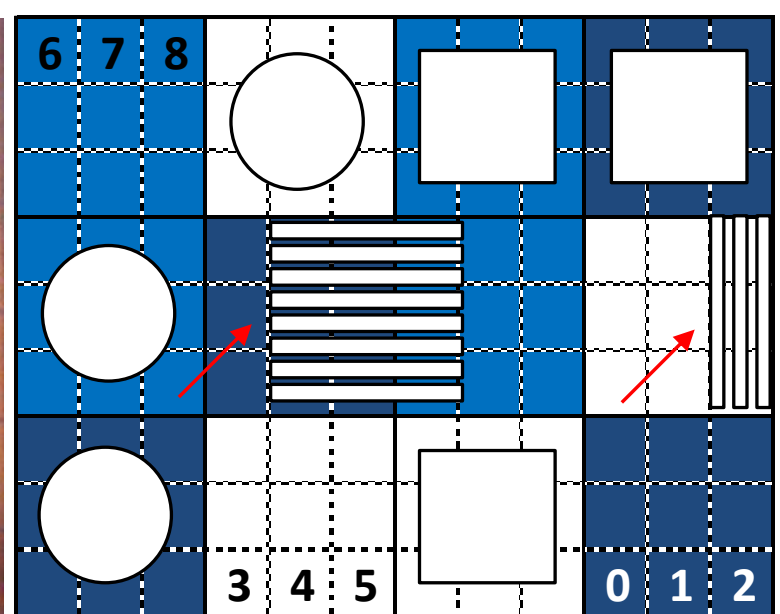

(b)

Figura 100. (a) Termograma do painel PCE3-B com grupos de defeitos destacados; (b) Defeitos de descolamento sob o revestimento cerâmico no painel PCE2-B. (Fonte: Elaborado pelo autor).

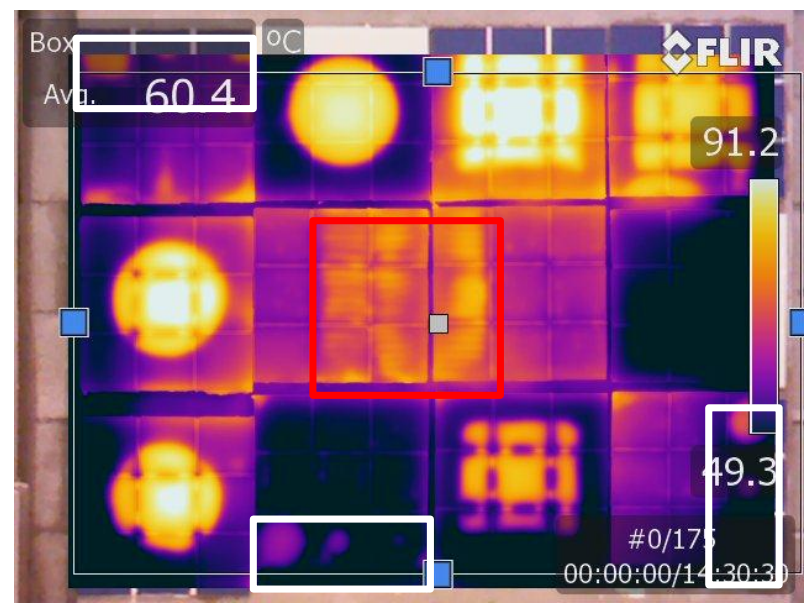

(a)

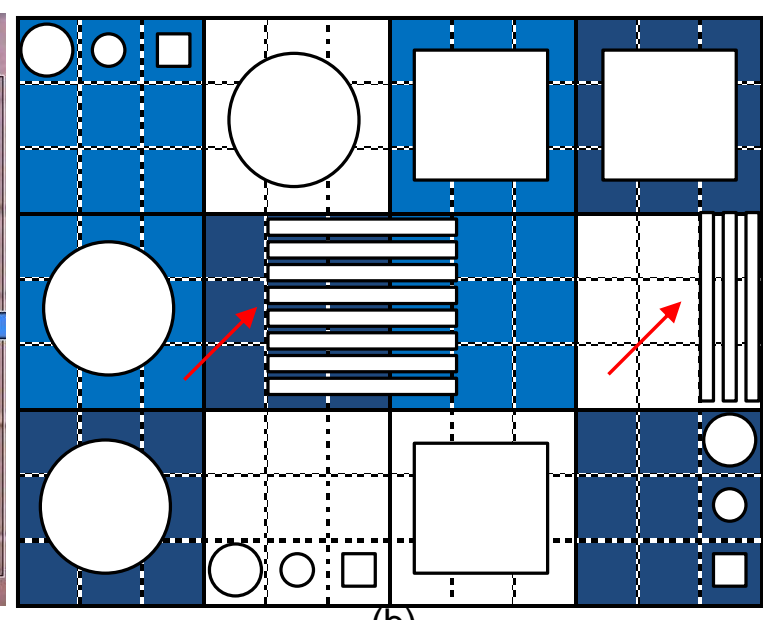

(b)

Figura 101. (a) Termograma do painel PCO3-A com grupos de defeitos destacados; (b) Defeitos de descolamento sob o revestimento cerâmico no painel PCO3-A. (Fonte:

Elaborado pelo autor). 


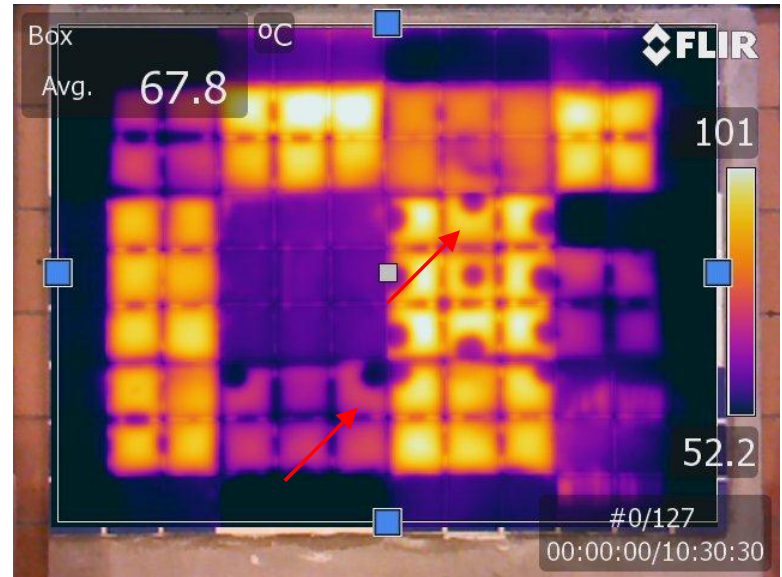

(a)

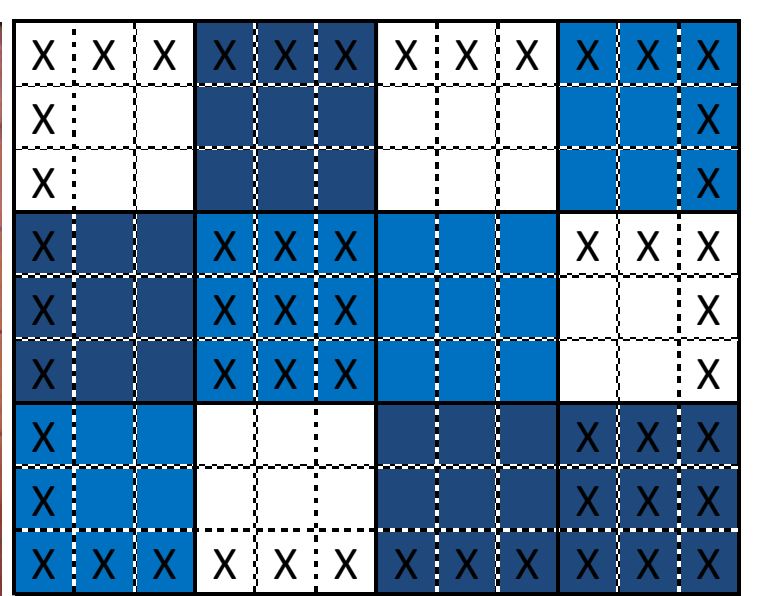

(b)

Figura 102. (a) Termograma do painel PCE3-A com grupos de defeitos destacados; (b) Defeitos de vazios de assentamento sob o revestimento cerâmico no painel PCE2-A. (Fonte: Elaborado pelo autor).

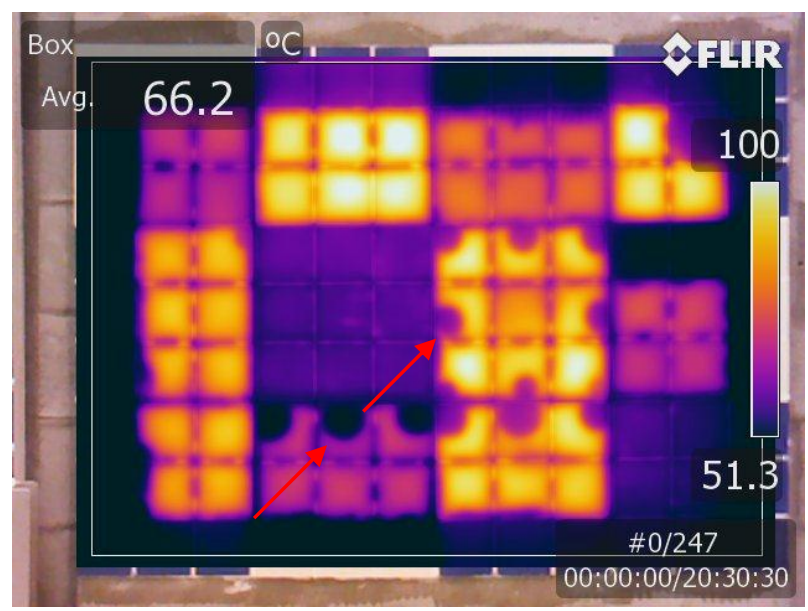

(a)

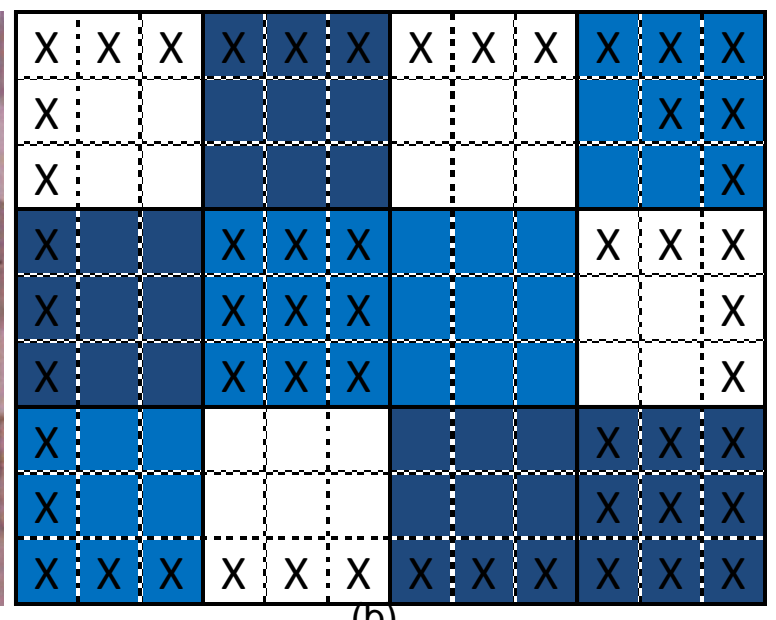

(b)

Figura 103. (a) Termograma do painel PCO3-B com grupos de defeitos destacados; (b) Defeitos de vazios de assentamento sob o revestimento cerâmico no painel PCO2-B. (Fonte: Elaborado pelo autor).

- após 15 minutos do início do resfriamento, a Figura 104-a mostra o termograma no momento de menor gradiente térmico registrado entre as áreas de defeito e não defeito. Visualmente não é possível identificar todos os defeitos simulados sob o revestimento cerâmico ilustrados na Figura 104c. Outros aparecem parcialmente sem definição clara de forma devido ao baixo gradiente térmico com a região ao redor (setas pretas na Figura 104a);

- após 45 minutos do início do resfriamento ocorre a inversão térmica entre as áreas de defeitos e não defeitos e os defeitos passam a apresentar uma temperatura mais baixa que as áreas de não defeitos (Figura 104-b). Nesse 
momento, as bordas apresentam-se ligeiramente menos definidas em razão da dispersão térmica (setas brancas na Figura 104-b), fazendo com que as dimensões dos defeitos fiquem ligeiramente alteradas em comparação com as originais;

- os defeitos representados nos retângulos vermelhos na Figura 104-c e Figura 105-c não foram visualizados nos termogramas durante o resfriamento.

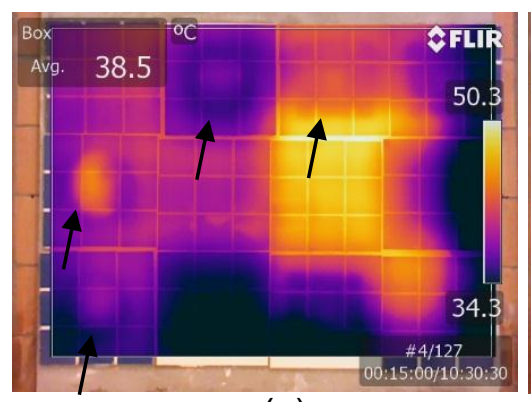

(a)

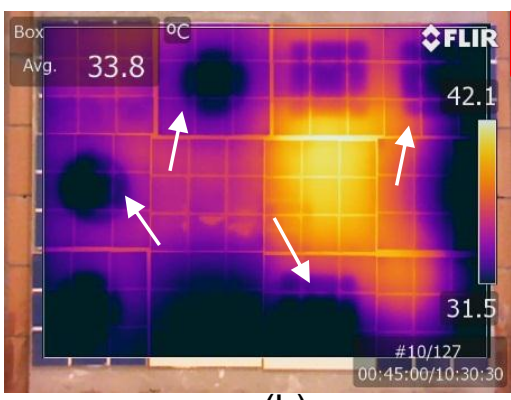

(b)

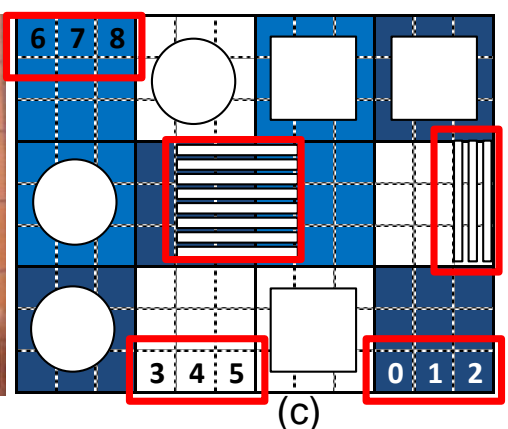

(c)

Figura 104. (a) Termograma do painel PCE3-B após 15 minutos do início do resfriamento; (b) Termograma do painel PCE3-B após 45 minutos do início do resfriamento; (c) Defeitos de descolamento sob o revestimento cerâmico no painel PCE3-B. (Fonte: Elaborado pelo autor).

- o painel PCO3-A apresentou o mesmo comportamento observado no painel PCE3-B, porém em intensidades e/ou momentos diferentes. O termograma com menor gradiente térmicco (Figura 105-a) ocorreu 15 minutos após início do resfriamento e a inversão térmica após 45 minutos (Figura 105-b).

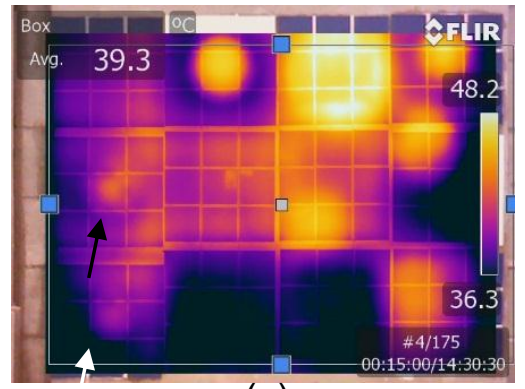

(a)

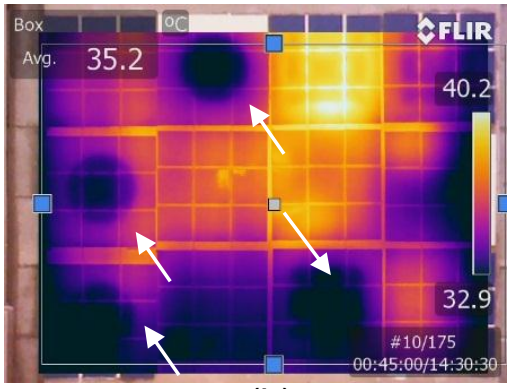

(b)

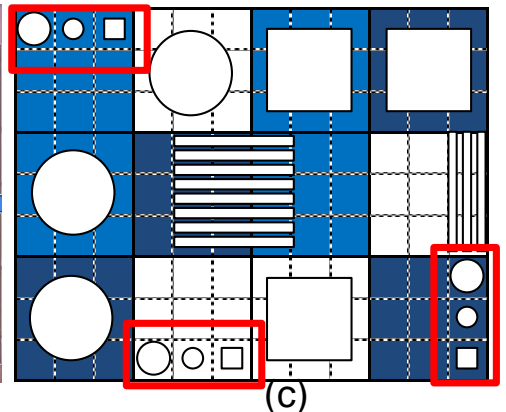

(c)

Figura 105. (a) Termograma do painel PCO3-A após 15 minutos do início do resfriamento; (b) Termograma do painel PCO3-A após 45 minutos do início do resfriamento; (c) Defeitos de descolamento sob o revestimento cerâmico no painel PCO3-A. (Fonte: Elaborado pelo autor).

- similar ao observado nas faces PCE3-B e PCO3-A, após 15 minutos do início do resfriamento, as faces PCE3-A e PCO3-B ilustradas na Figura 106-a e b 
encontraram-se no menor gradiente térmico registrado entre as áreas de defeito e não defeito não sendo possível identificar visualmente os defeitos de vazios de argamassa de assentamento cerâmico;

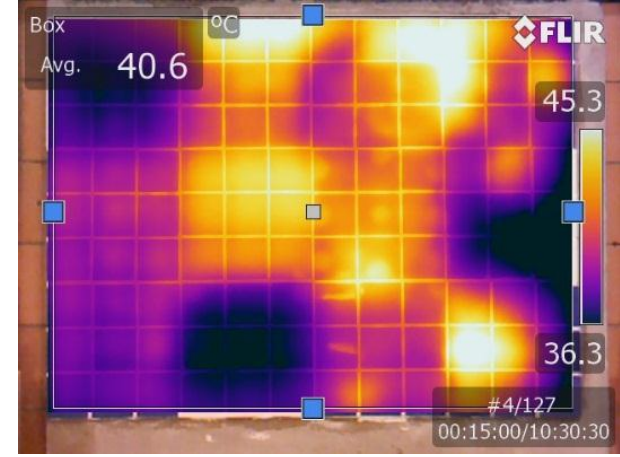

(a)

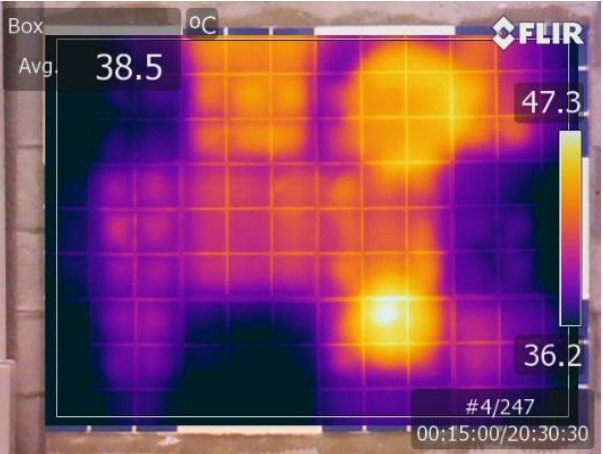

(b)

Figura 106. (a) Termograma do painel PCE3-A após 15 minutos do início do resfriamento; (b) Termograma do painel PCO3-B após 15 minutos do início do resfriamento. (Fonte:

Elaborado pelo autor).

- os defeitos representados pela área sem a marcação "X" na Figura 107-b e Figura 108-b foram visualizados com baixa clareza no painel PCE3-B e praticamente nenhuma no painel PCO3-A.

- pontos de fixação com argamassa colante (setas vermelhas na Figura 107-a e Figura 108-a) ficaram visíveis com temperaturas mais altas que o seu entorno.

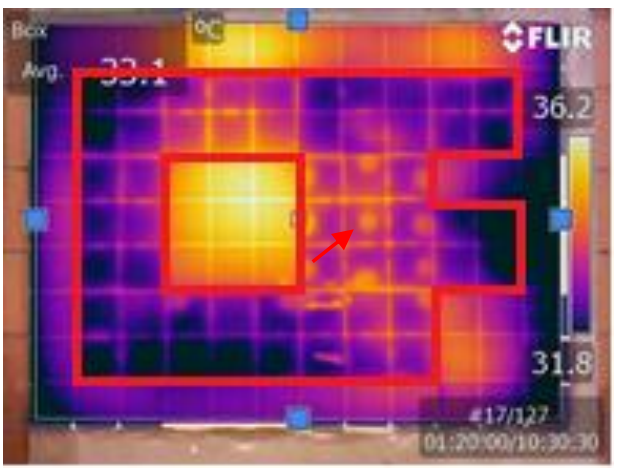

(a)

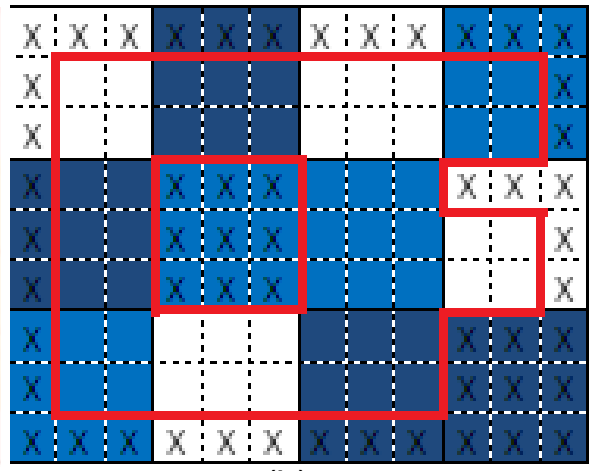

(b)

Figura 107. (a) Termograma do painel PCE3-B após 80 minutos do início do resfriamento; (b) Defeitos de vazios de assentamento sob o revestimento cerâmico no painel PCE3-B. (Fonte: Elaborado pelo autor). 


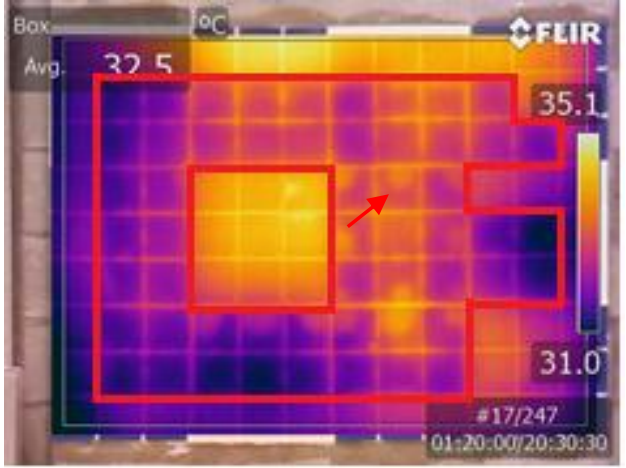

(a)

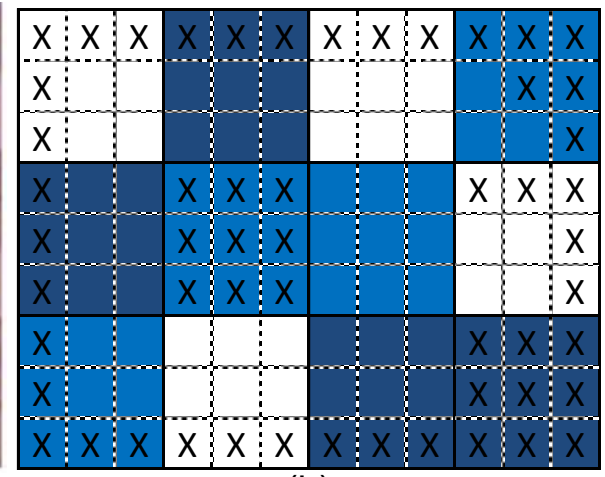

(b)

Figura 108. (a) Termograma do painel PCO3-A após 80 minutos do início do resfriamento; (b) Defeitos de vazios de assentamento sob o revestimento cerâmico no painel PCO3-A.

(Fonte: Elaborado pelo autor).

- o tempo de visualização do defeito foi praticamente o mesmo entre os painéis PCO3-A e B (Figura 109 e Figura 110), porém 45\% menor quando comparado com os painéis PCE2 e PCO2 (reboco).

- após sete horas, a diferença térmica entre defeitos e não defeitos praticamente torna imperceptível a visualização dos defeitos.

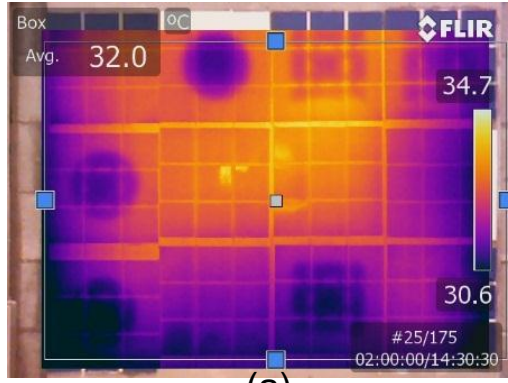

(a)

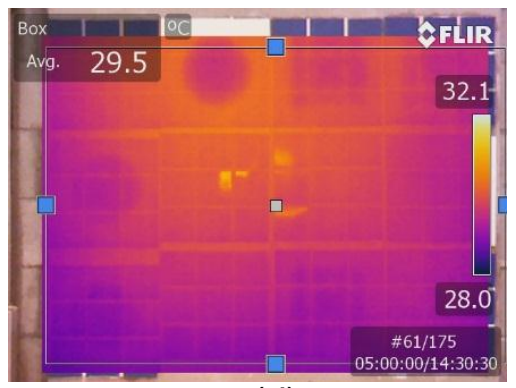

(d)

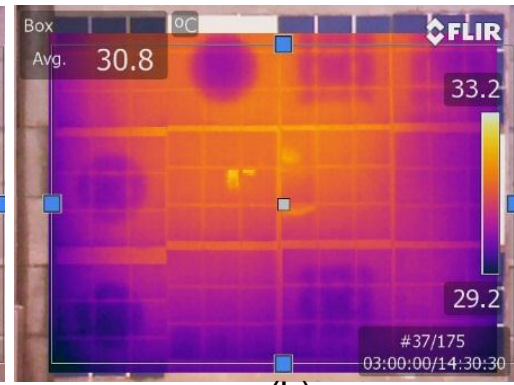

(b)

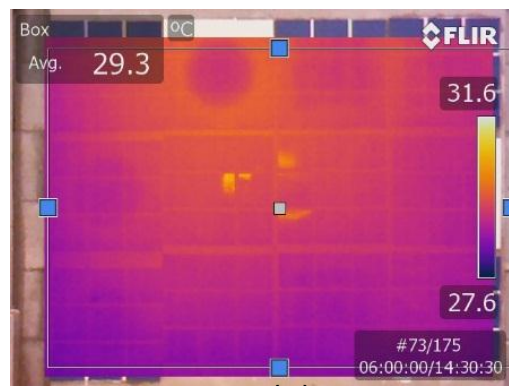

(e)

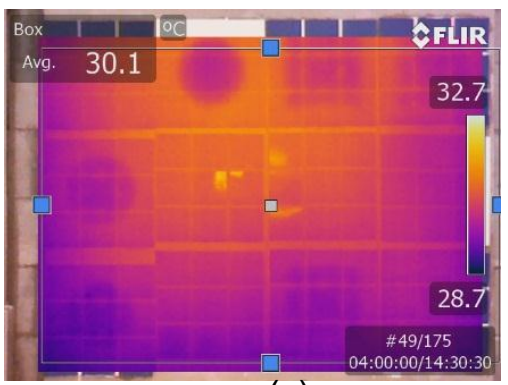

(c)

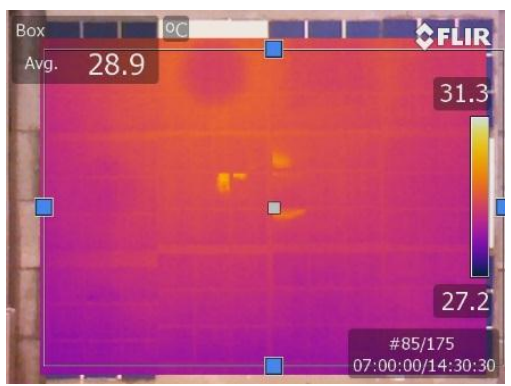

(f)

Figura 109. Termograma do painel PCO3-A após início do resfriamento: (a) duas horas após; (b) três horas após; (c) quatro horas após; (d) cinco horas após; (e) seis horas após;

(f) sete horas após. (Fonte: Elaborado pelo autor). 


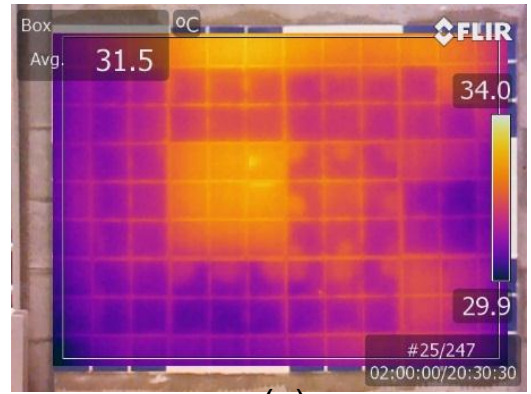

(a)

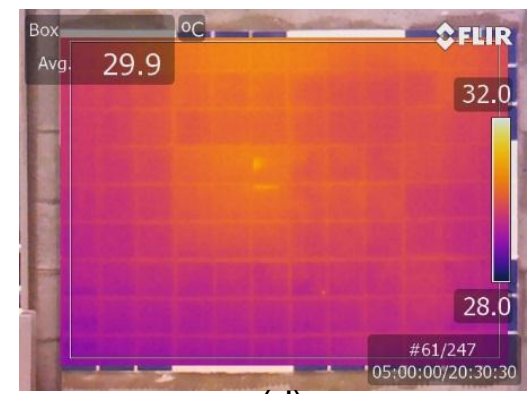

(d)

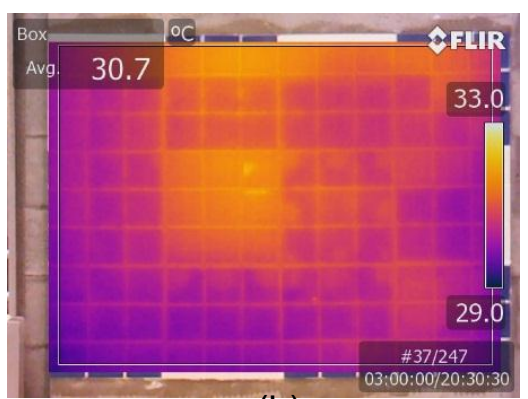

(b)

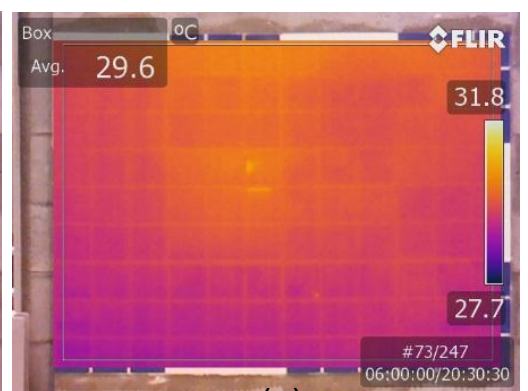

(e)

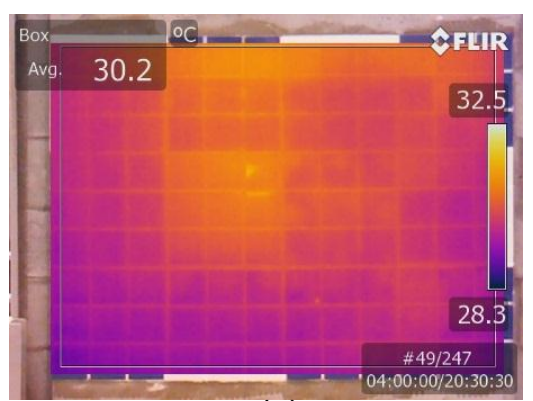

(c)

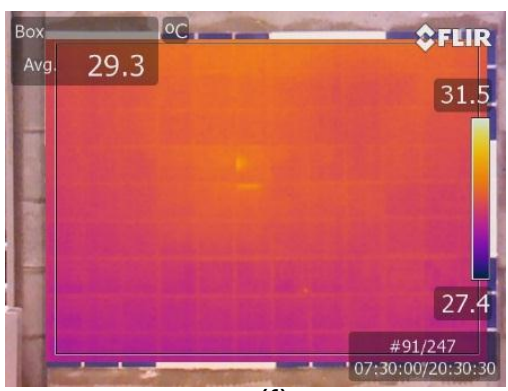

(f)

Figura 110. Termograma do painel PCO3-B após início do resfriamento: (a) duas horas após; (b) três horas após; (c) quatro horas após; (d) cinco horas após; (e) seis horas após; (f) sete horas após. (Fonte: Elaborado pelo autor).

- passados 210 minutos (Figura 111-b e Figura 112-b) e 330 minutos (Figura 111-c e Figura 112-c) do início do resfriamento os defeitos foram visualmente menos intensos que o momento imediatamente após o aquecimento se destacando menos em relação às áreas de não defeitos, porém com perfeita definição de forma e de localização até o momento de menor gradiente térmico.

- reflexos de objetos próximos à superfície do revestimento cerâmico (elipse branca na Figura 111 e Figura 112) puderam confundir-se com defeitos de desplacamento.

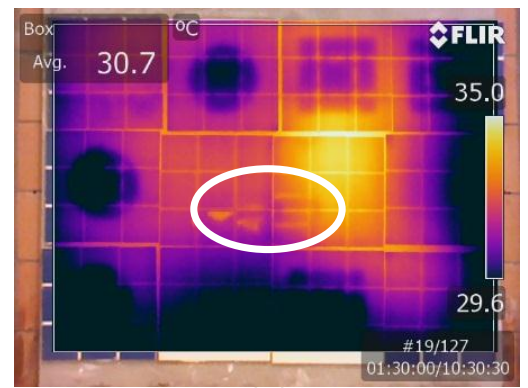

(a)

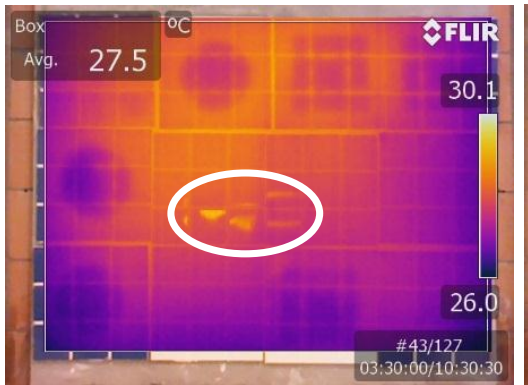

(b)

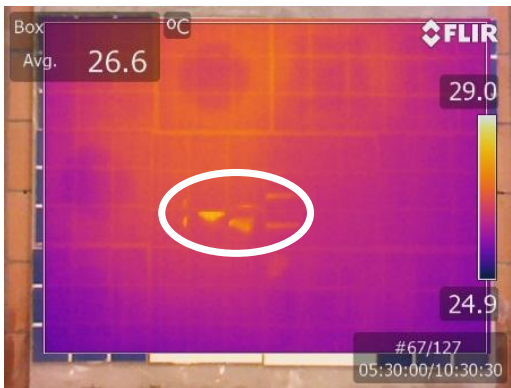

(c)

Figura 111. Termograma do painel PCE3-B após do início do resfriamento: (a) 90 minutos após; (b) 210 minutos após; (c) 330 minutos após. (Fonte: Elaborado pelo autor). 


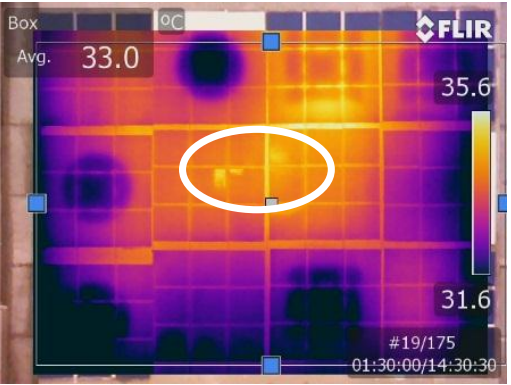

(a)

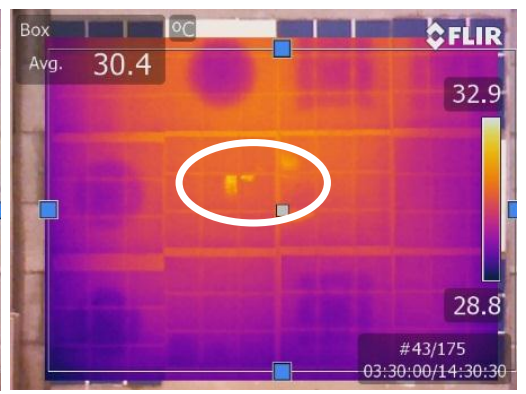

(b)

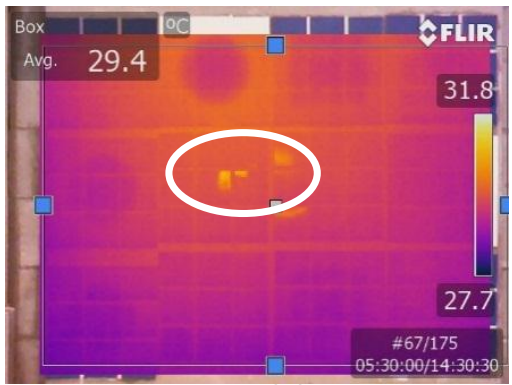

(c)

Figura 112. Termograma do painel PCO3-A após do início do resfriamento: (a) 90 minutos após; (b) 210 minutos após; (c) 330 minutos após. (Fonte: Elaborado pelo autor).

- a visibilida de dos defeitos no termograma do painel PCO3 e PCE3 faces A e B sem rejunte (Figura 113-a, Figura 114-a, Figura 115-a, Figura 116-a e Figura 117-a) e com rejuntamento (Figura 113-b, Figura 114-b, Figura 115-b, Figura 116-b e Figura 117-b) aplicado nas juntas do revestimento cerâmico, apresentou-se similar, no entanto, na condição sem rejunte observou-se uma melhor definição das bordas das regiões com defeito e das próprias juntas entre peças cerâmicas.

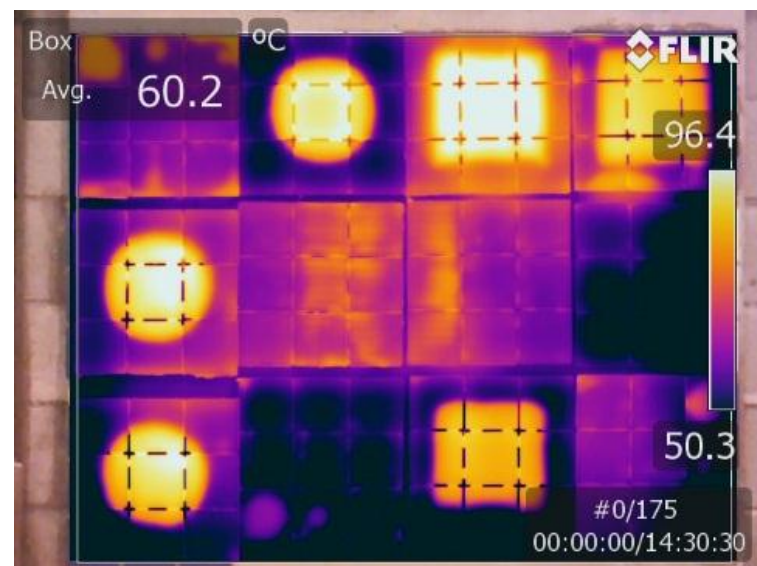

(a)

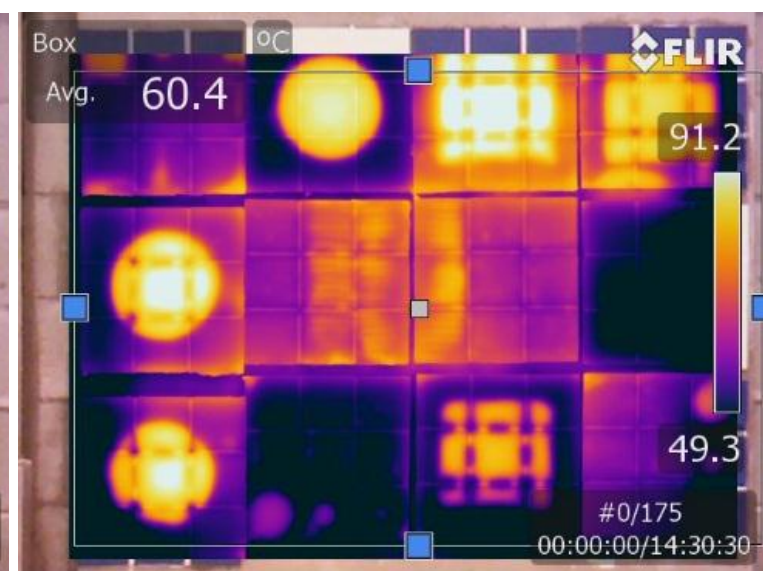

(b)

Figura 113. (a) Termograma do painel PCO3-A sem rejuntamento logo após aquecimento;

(b) Termograma do painel PCO3-A com rejuntamento logo após aquecimento. (Fonte:

Elaborado pelo autor). 


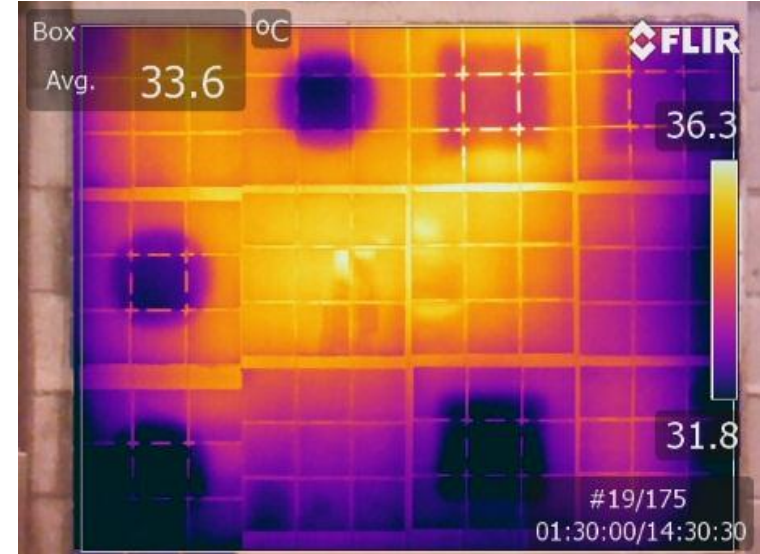

(a)

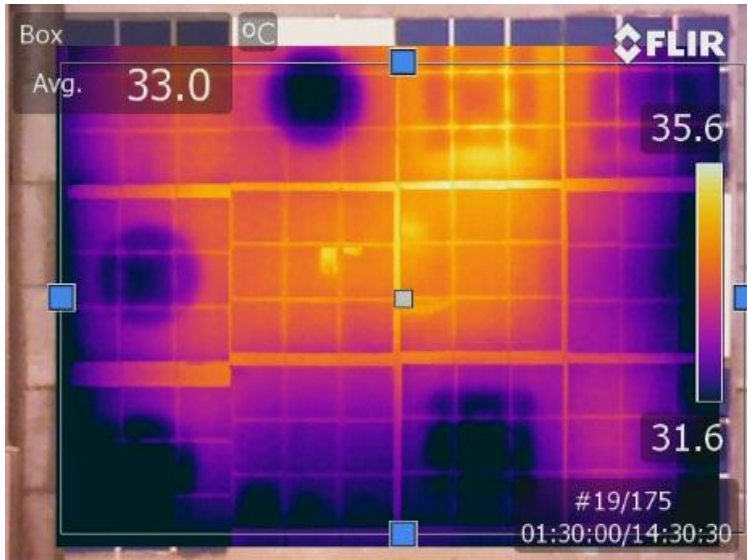

(b)

Figura 114. (a) Termograma do painel PCO3-A sem rejuntamento durante resfriamento natural; (b) Termograma do painel PCO3-A com rejuntamento durante resfriamento natural. (Fonte: Elaborado pelo autor).

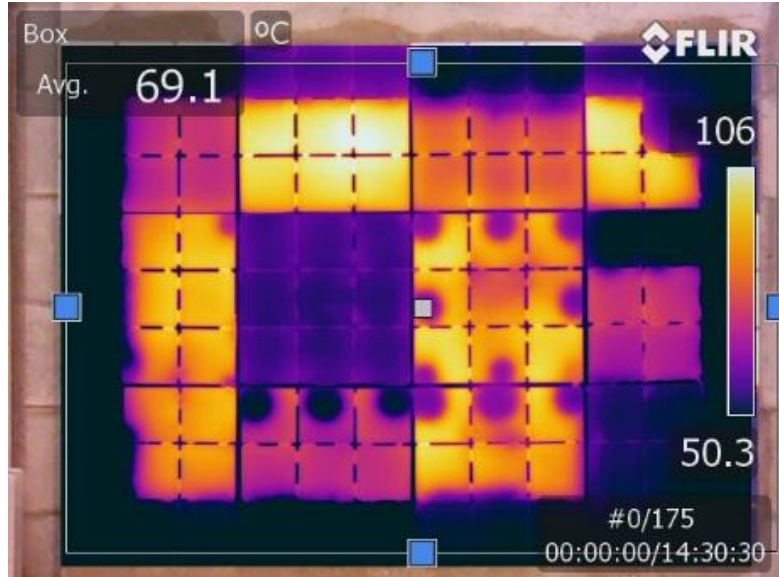

(a)

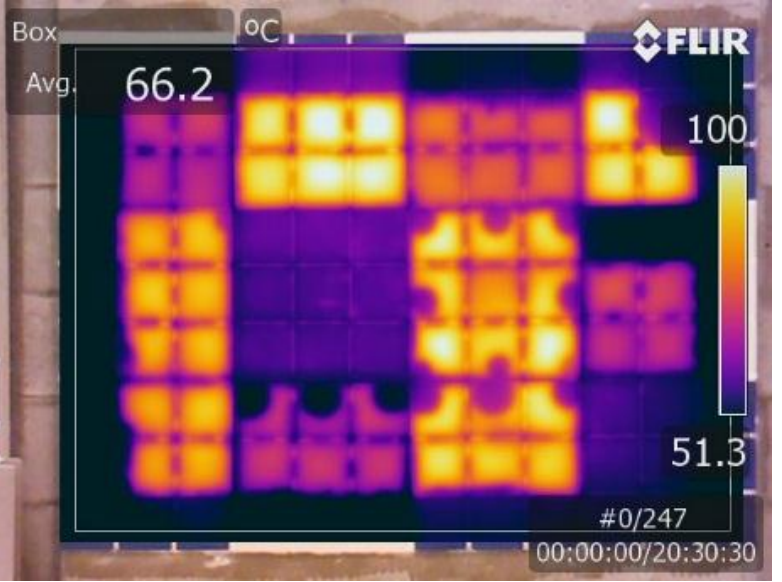

(b)

Figura 115. (a) Termograma do painel PCO3-B sem rejuntamento logo após aquecimento;

(b) Termograma do painel PCO3-B com rejuntamento logo após aquecimento. (Fonte: Elaborado pelo autor).

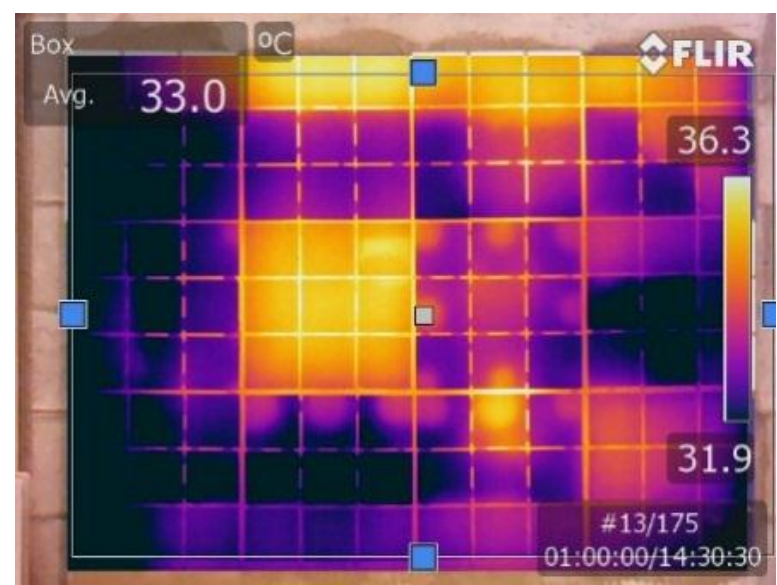

(a)

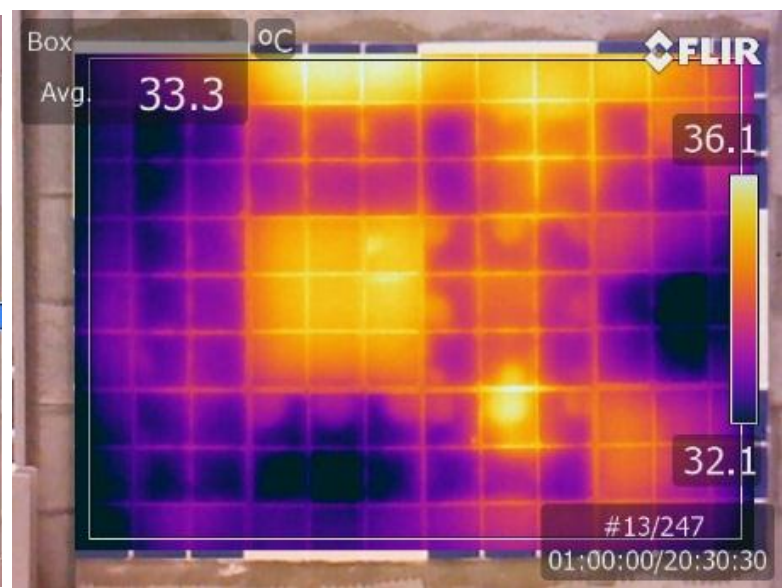

(b)

Figura 116. (a) Termograma do painel PCO3-B sem rejuntamento durante resfriamento natural; (b) Termograma do painel PCO3-B com rejuntamento durante resfriamento natural. (Fonte: Elaborado pelo autor). 


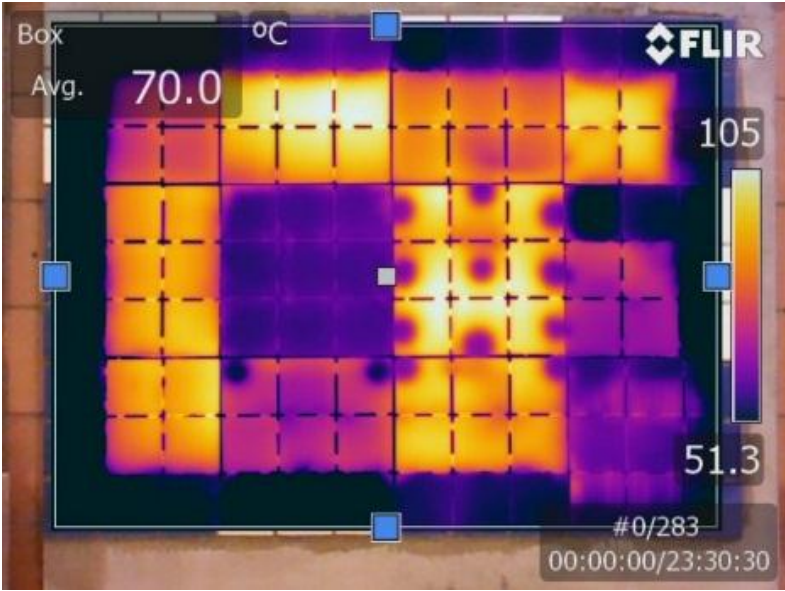

(a)

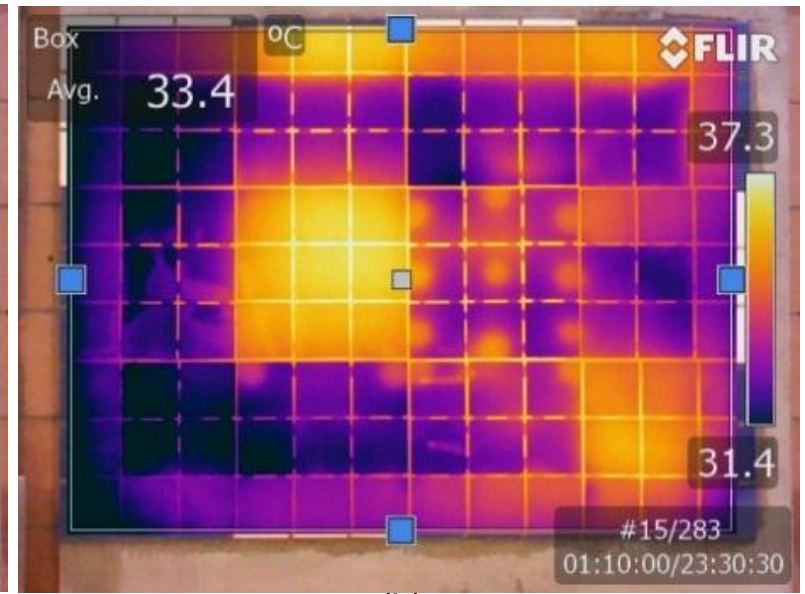

(b)

Figura 117. Termograma do painel PCE3-A sem rejuntamento: (a) imediatamente após aquecimento; (b) 70 minutos após início do resfriamento natural. (Fonte: Elaborado pelo autor).

- quando as juntas do revestimento cerâmico estavam preenchidas com rejuntamento observou-se uma redução do tempo total de visualização dos defeitos de desplacamento de doze (Figura 118-a) para oito horas (Figura 118-b) durante o resfriamento natural. Para ambas as análises foi realizado o mesmo tempo de aquecimento com o painel térmico.

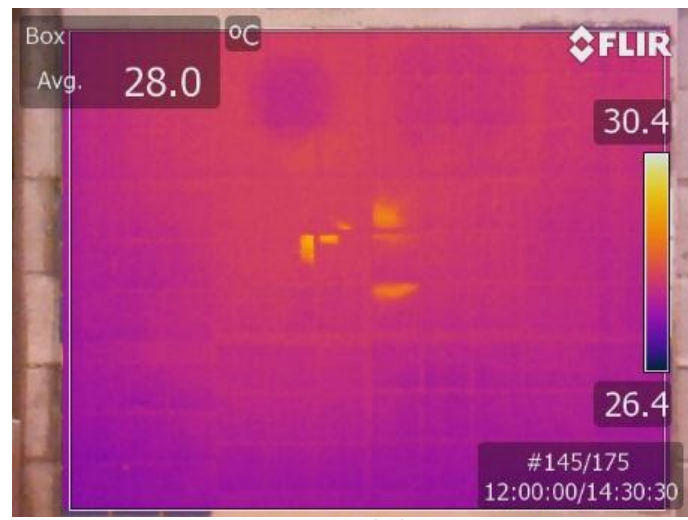

(a)

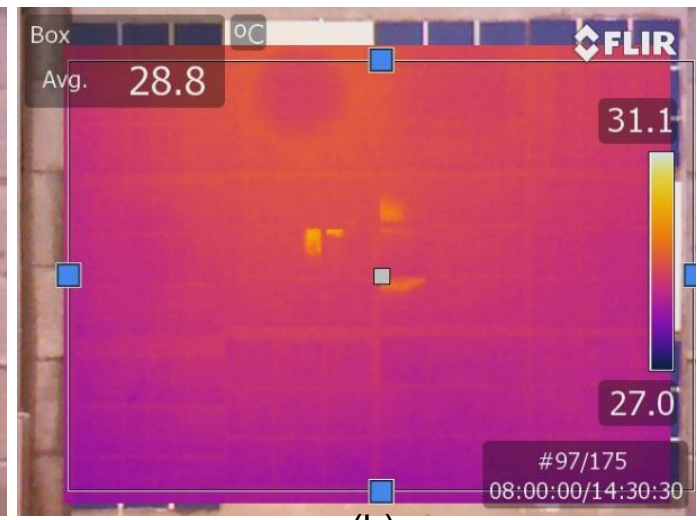

(b)

Figura 118. (a) Termograma do painel PCO3-A sem rejuntamento após 12 horas de resfriamento natural; (b) Termograma do painel PCO3-A com rejuntamento após 8 horas de resfriamento natural. (Fonte: Elaborado pelo autor).

No resfriamento forçado com água, imediatamente após o aquecimento com o painel térmico na etapa de laboratório foram observados os seguintes comportamentos:

- imediatamente após o resfriamento forçado é possível identificar os defeitos mesmo com a interferência causada pelo escorrimento de água sobre a superfície dos painéis PCE3 e PCO3 (Figura 119 e Figura 120). Situação contrária à observada nos painéis PCE2 e PCO2. 


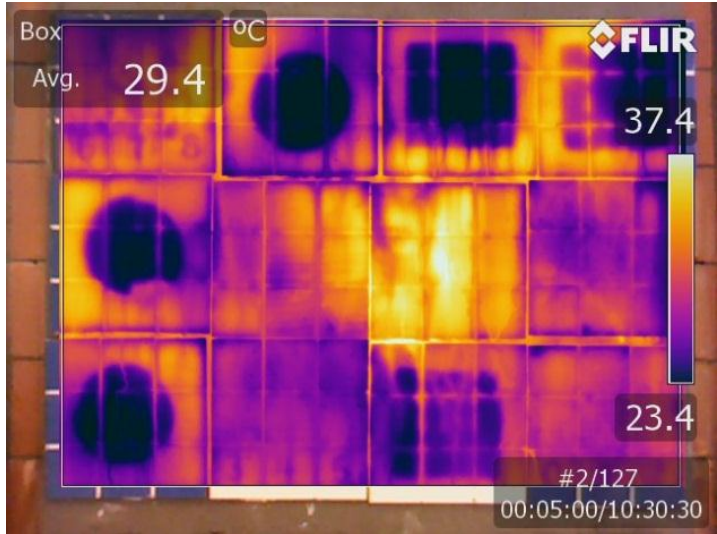

(a)

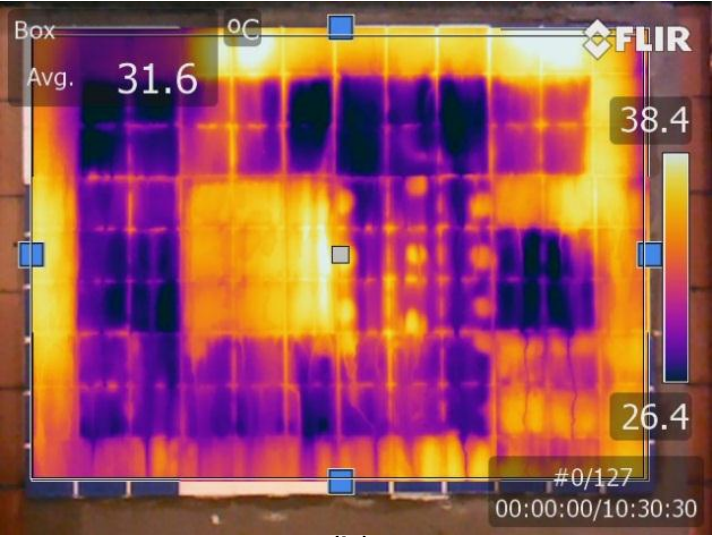

(b)

Figura 119. (a) Termograma do painel PCE2-B imediatamente após resfriamento forçado com água: (b) Termograma do painel PCE2-A imediatamente após resfriamento forçado com água. (Fonte: Elaborado pelo autor).

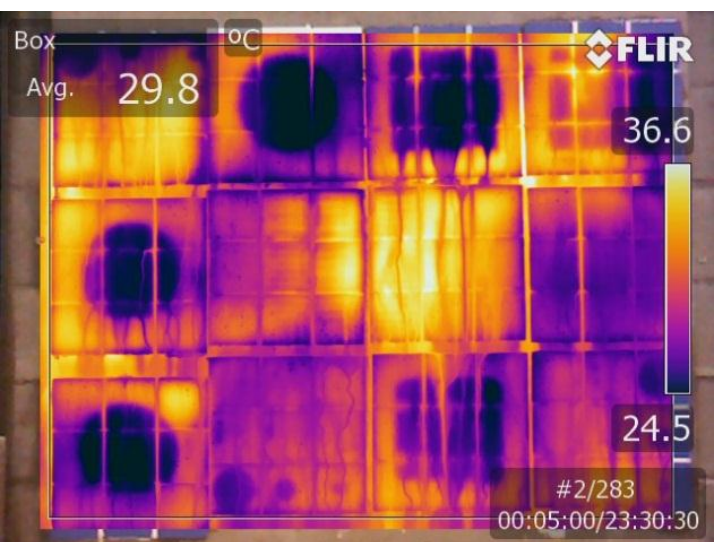

(a)

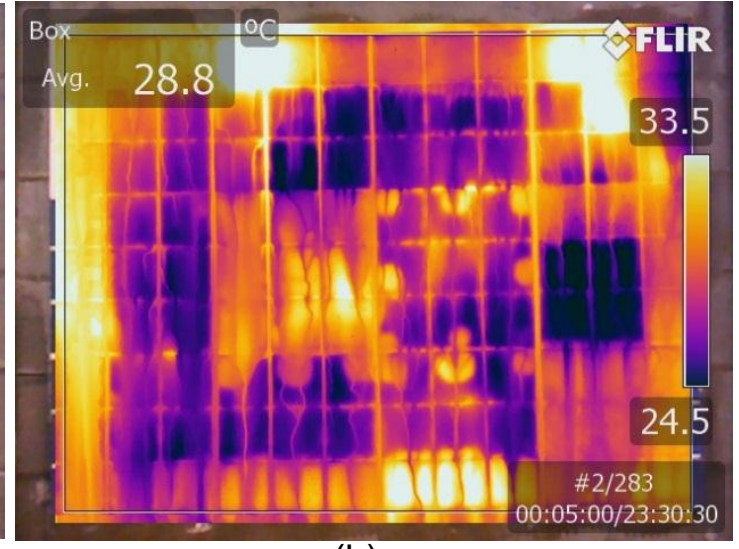

(b)

Figura 120. (a) Termograma do painel PCO2-A imediatamente após resfriamento forçado com água: (b) Termograma do painel PCO2-B imediatamente após resfriamento forçado com água. (Fonte: Elaborado pelo autor).

- passados os primeiros minutos de resfriamento forçado:

- passados 10 minutos do resfriamento forçado com água foi possível visualizar com precisão superior ao resfriamento ambiente (Figura 121-a, Figura 122-a e Figura 123-a) a forma e a posição dos defeitos quanto a dimensão e a definição das bordas devido ao choque térmico gerado pela água em contato com a superfície aquecida (Figura 121-b, Figura 122-b e Figura 123-b), aumentando o gradiente térmico e melhorando o contraste entre áreas com e sem defeito. A qualidade visual dos defeitos aproximouse da observada no termograma imediatamente após o aquecimento com painel térmico (Figura 121-c, Figura 122-c e Figura 123-c). 
- a melhora na visibilidade dos defeitos também foi resultado da maior uniformidade de temperatura em toda a área do painel após o resfriamento com água.

- o defeito simulando cordões de argamassa não esmagados durante o processo de aplicação da argamassa observado no termograma registrado imediatamente após o aquecimento (quadrado branco na Figura 121-c) não foi observado com precisão após o resfriamento com água (quadrado branco na Figura 121-b).

- os defeitos circulares de 100 e $50 \mathrm{~mm}$ foram visualizados como na condição imediatamente após o aquecimento no painel PCO3-A (setas vermelhas na Figura 121-b), porém com inversão térmica. Já no painel PCE3-B (Figura 123-b) esse defeito não foi visível.

- os defeitos simulados com os números de 0 a 8 em EVA (Figura 121-b) continuaram não sendo visíveis.

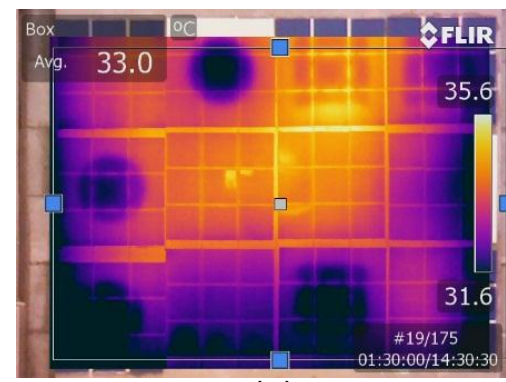

(a)

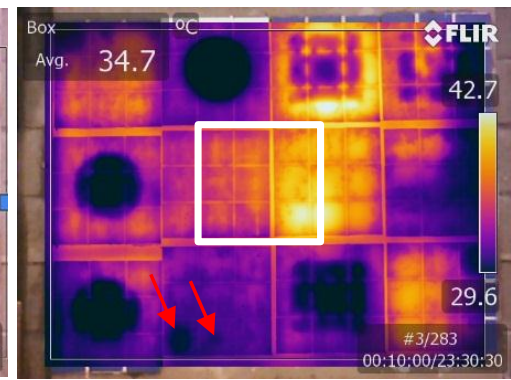

(b)

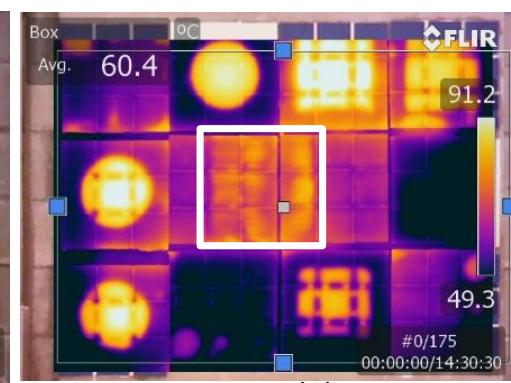

(c)

Figura 121. Termograma do painel PCO3-A: (a) Melhor definição dos defeitos durante arrefecimento natural; (b) Após arrefecimento forçado com água; (c) Logo após aquecimento. (Fonte: Elaborado pelo autor).

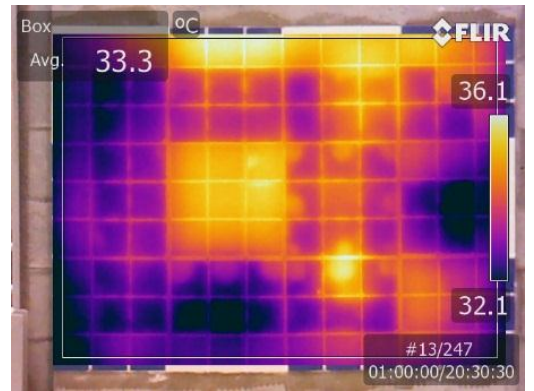

(a)

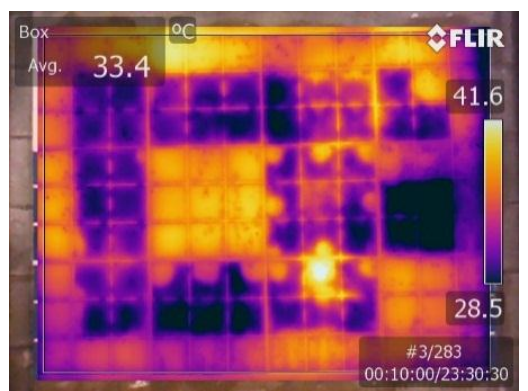

(b)

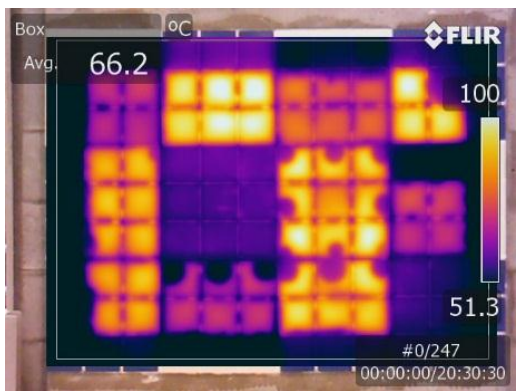

(c)

Figura 122. Termograma do painel PCO3-B: (a) Melhor definição dos defeitos durante arrefecimento natural; (b) Após arrefecimento forçado com água; (c) Logo após aquecimento. (Fonte: Elaborado pelo autor). 


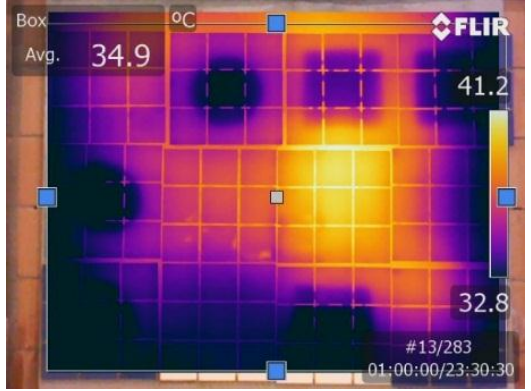

(a)

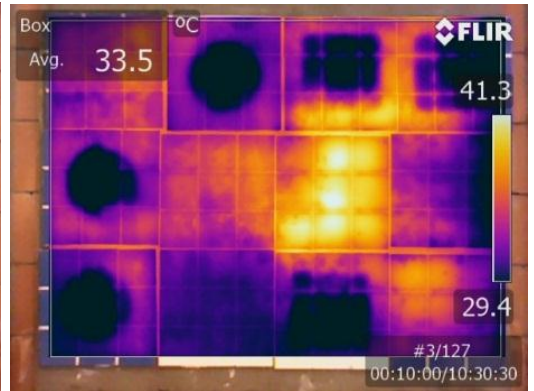

(b)

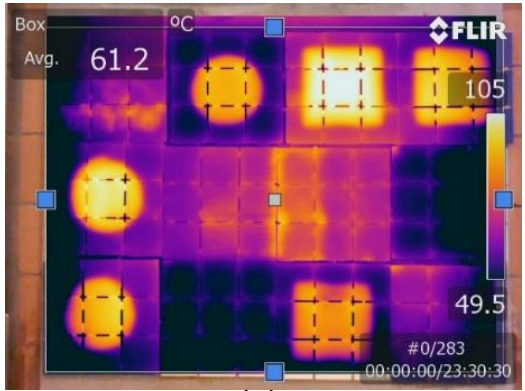

(c)

Figura 123. Termograma do painel PCE3-B: (a) Melhor definição dos defeitos durante arrefecimento natural; (b) Após arrefecimento forçado com água; (c) Logo após aquecimento. (Fonte: Elaborado pelo autor).

- passadas as primeiras horas de resfriamento forçado:

- a partir da primeira hora de resfriamento houve uma perda da forma e da dimensão dos defeitos dificultando/inviabilizando gradativamente sua identificação (setas brancas na Figura 124). As bordas dos defeitos mantiveram-se menos definidas em relação ao resfriamento natural em razão da maior dispersão térmica, prejudicando a identificação da forma/dimensão do defeito.

- a visualização dos defeitos permaneceu por menos tempo em comparação com a condição de resfriamento ambiente.

- as mesmas observações ocorreram para o painel PCO3.

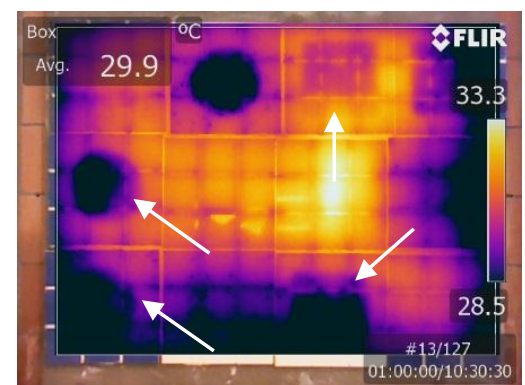

(a)

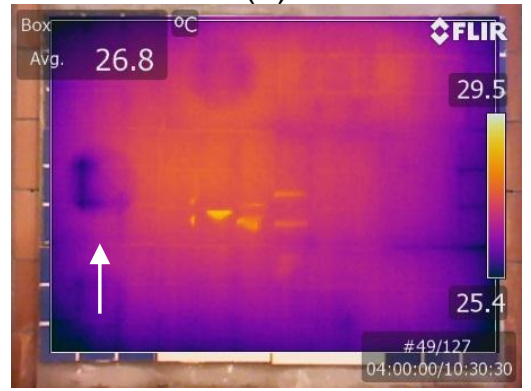

(d)

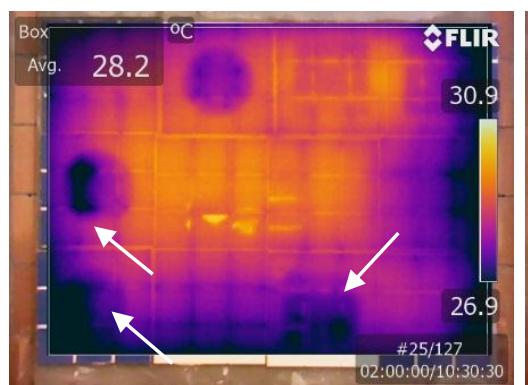

(b)

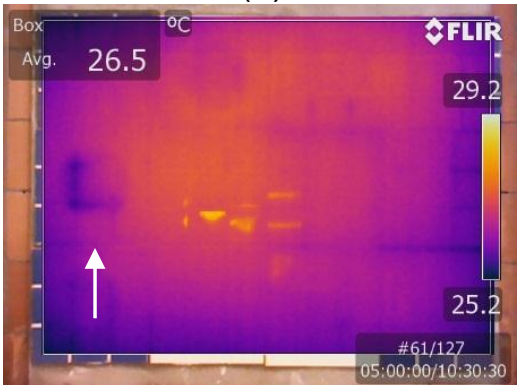

(e)

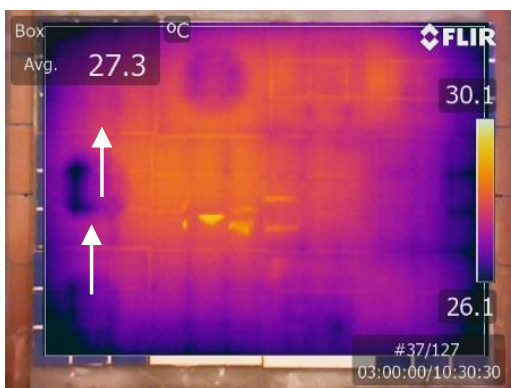

(c)

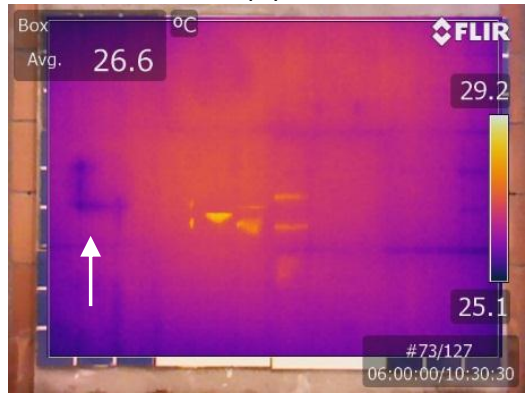

(f)

Figura 124. Termograma do painel PCE3-B após resfriamento forçado com água: (a) uma hora após; (b) duas horas após; (c) três horas após; (d) quatro horas após; (e) cinco horas após; (f) seis horas após. (Fonte: Elaborado pelo autor). 


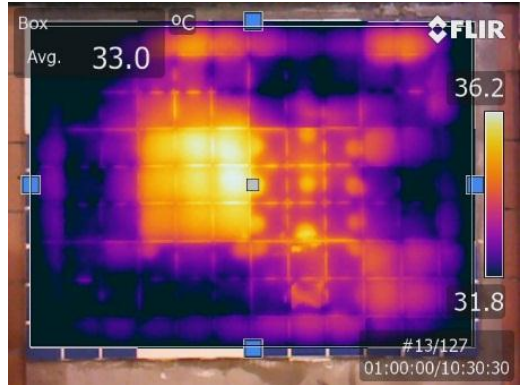

(a)

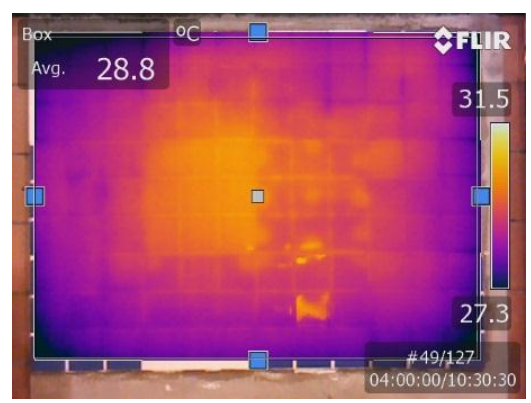

(d)

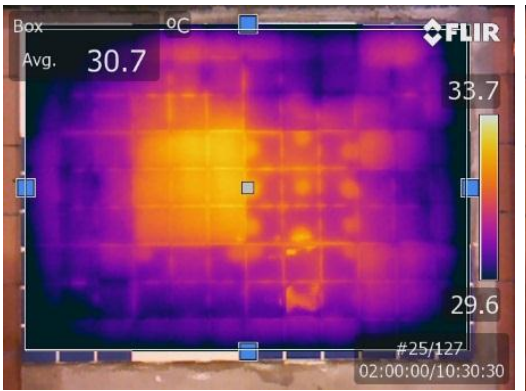

(b)

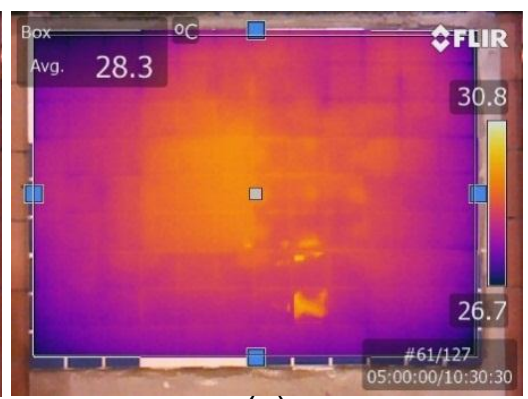

(e)

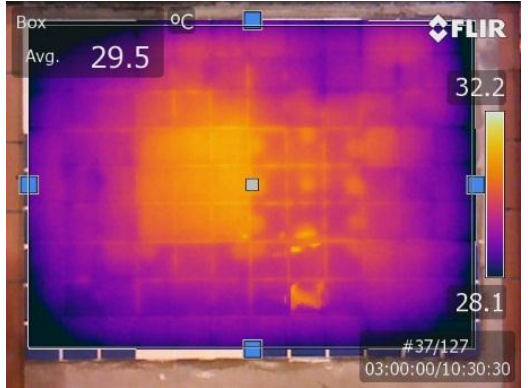

(c)

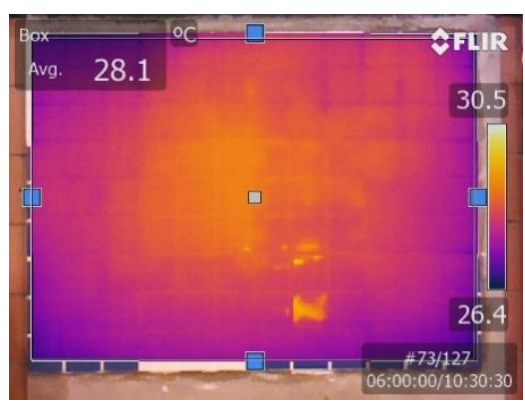

(f)

Figura 125. Termograma do painel PCE3-A após resfriamento forçado com água: (a) uma hora após; (b) duas horas após; (c) três horas após; (d) quatro horas após; (e) cinco horas após; (f) seis horas após. (Fonte: Elaborado pelo autor).

\section{- Campo}

Neste estudo, a radiação solar na parede foi considerada como uniforme, por estar incidida em todo o painel por igual.

No aquecimento ao sol foram observados os seguintes comportamento nos termogramas do painel PCO3-A, único painel com revestimento cerâmico estudado nesta condição:

- uniformidade na incidência de energia térmica sobre os painéis;

- os defeitos apresentaram-se com temperaturas superiores às áreas de não defeitos durante todo o período de aquecimento;

- imediatamente após o posicionamento do painel ao sol na área externa do laboratório os defeitos quadrados e circulares de $200 \mathrm{~mm}$ de lado e diâmetro, respectivamente (setas brancas na Figura 126-a), já se tornaram visíveis quanto à forma, localização e dimensão;

- a temperatura na superfície da cerâmica sobre o defeito encontrava-se acima da temperatura da área ao redor (Figura 126-a); 
- a temperatura registrada na superfície da cerâmica branca (Figura 126-a) era menor comparada com as cerâmicas azuis.

- passados cinco minutos de exposição ao sol:

- os defeitos circulares de 100 e 50 mm de diâmetro (retângulo preto na Figura 126-b) ficaram visíveis com forma definida, mas dimensões acima do original, e o defeito quadrado de $50 \mathrm{~mm}$ de lado (seta preta na Figura 126-b) começou a aparecer, mas sem definição de forma e de dimensão (seta branca na Figura 126-c).

- os defeitos simulando os cordões de argamassa posicionados sob as cerâmicas de cor azul tiveram seu limite externo levemente definido (retângulo branco na Figura 126-b), porém não foi possível identificar a forma de cada cordão isoladamente. Já os cordões sob a cerâmica branca não eram visíveis (retângulo vermelho na Figura 126-b).

- houve um aumento do contraste térmico entre defeitos já identificados e as áreas de não defeitos (Figura 126), mais intenso sobre as cerâmicas escuras.

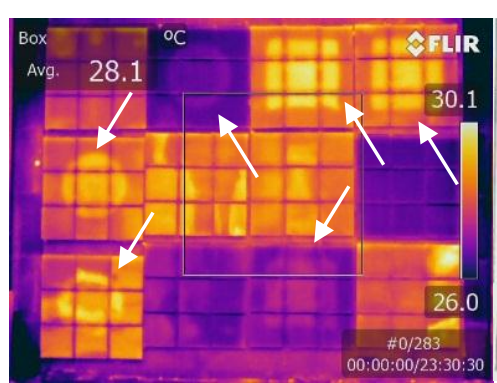

(a)

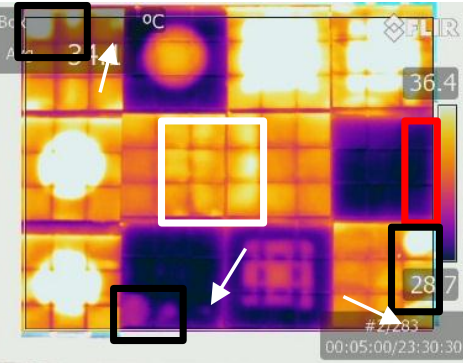

(b)

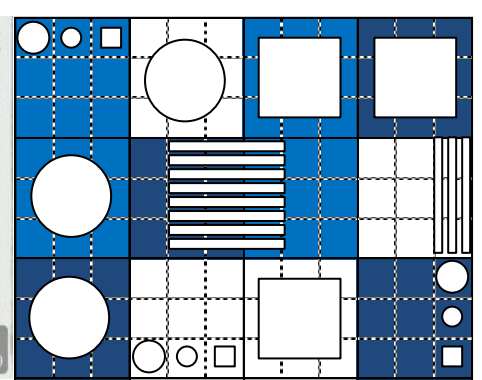

(c)

Figura 126. (a) Termograma do painel PCO3-A no início do aquecimento; (b) Termograma do painel PCO3-A após 5 minutos do início do aquecimento; (c) Defeitos de desplacamento sob o revestimento cerâmico no painel PCO3-A. (Fonte: Elaborado pelo autor).

- reflexos sobre a superfície da cerâmica geraram interpretações equivocadas através da visualização dos defeitos inexistentes ou ao distorcer defeitos reais (elipse branca na Figura 127-a). Ocorrência identificada principalmente sobre a cerâmica resinada azul destacadas nos retângulos vermelhos na Figura 127-b. 


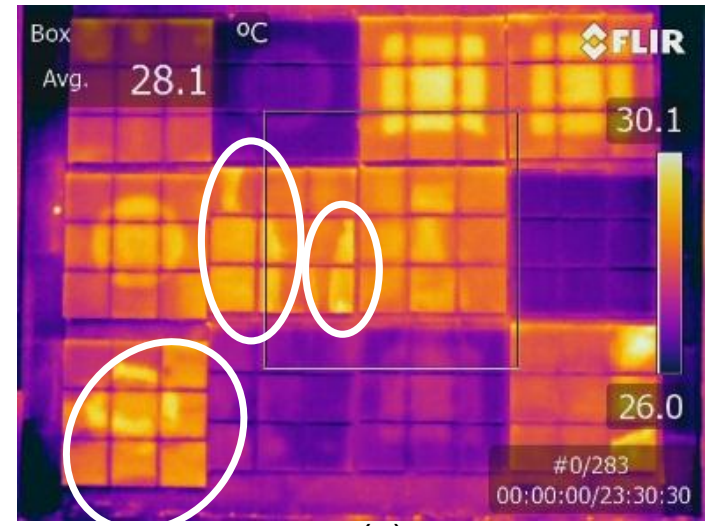

(a)

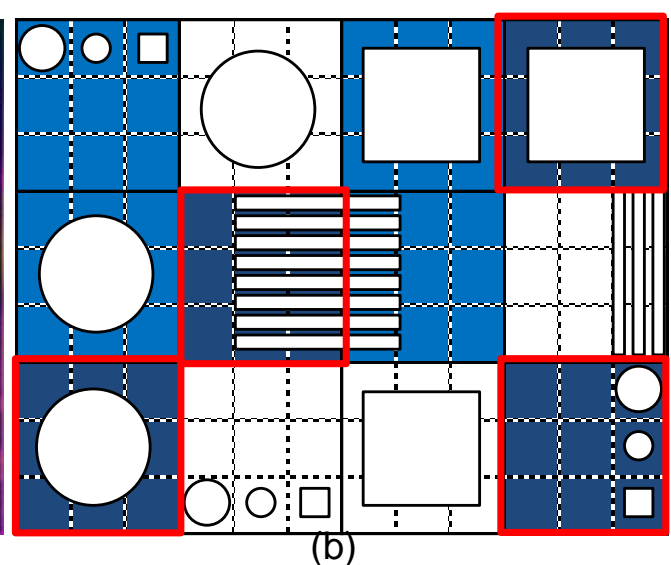

(b)

Figura 127. (a) Termograma do painel PCO3-A no início do aquecimento; (b) Defeitos de desplacamento sob o revestimento cerâmico no painel PCO3-A. (Fonte: Elaborado pelo autor).

- com a evolução do aquecimento (30, 60 e 95 minutos):

- após 30 minutos de aquecimento houve um aumento do contraste térmico entre defeitos e as áreas de não defeitos próximos e acentuou-se a diferença de temperatura registrada sobre cerâmicas de diferentes tonalidades (Figura 128-a);

- observou-se a perda dos limites de borda de alguns defeitos (setas vermelhas e retângulos pretos na Figura 128-a, b e c) dificultando/ inviabilizando a identificação da forma e da dimensão;

- áreas de defeito e não defeito começaram a equilibrar suas temperaturas devido ao aumento do tempo de exposição ao sol, diminuindo a visibilidade dos defeitos: simulando os cordões de argamassa e vazio sob cerâmica branca (retângulos brancos e setas brancas na Figura 128-a, b e c).

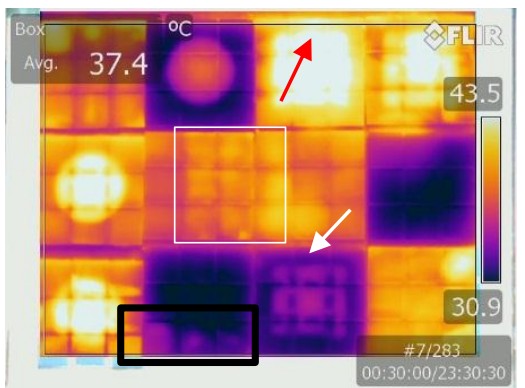

(a)

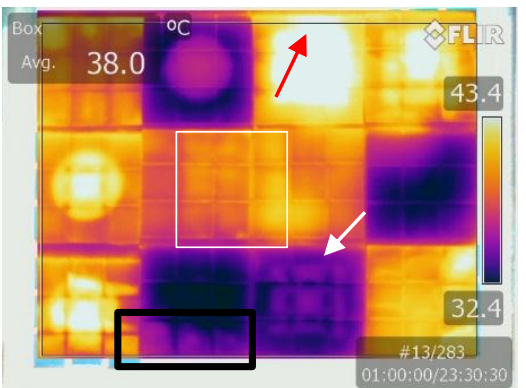

(b)

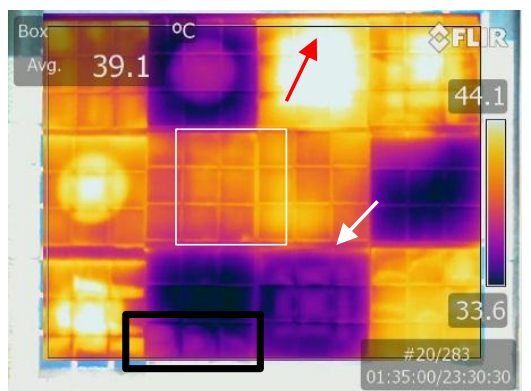

(c)

Figura 128. Termograma do painel PCO3-A durante aquecimento ao sol: (a) 30 minutos de aquecimento; (b) 60 minutos de aquecimento; (c) 95 minutos de aquecimento. (Fonte: Elaborado pelo autor). 
A etapa de resfriamento à sombra no painel PCO3-A iniciou após 95 minutos de aquecimento devido à presença de nuvens que encobriram o sol. $\mathrm{Na}$ condição de resfriamento observaram-se:

- apenas no termograma registrado 60 minutos após o início do resfriamento, os defeitos sob a cerâmica (Figura 129-a) ficaram não visíveis ou indefinidos quanto a forma e dimensão devido a um menor gradiente térmico entre as áreas de não defeito.

- após 90 minutos ocorre a inversão térmica (defeitos mais frios em relação às áreas de não defeitos) dos defeitos circulares de $200 \mathrm{~mm}$ de diâmetro indicados com as setas brancas na Figura 129-b.

- após 210 minutos os outros defeitos circulares e quadrados com $200 \mathrm{~mm}$ de diâmetro e lado, respectivamente (setas brancas na Figura 129-c), e os defeitos circulares de 100 e 50 mm (retângulos brancos na Figura 129-c) ficaram visíveis. Em princípio não foi identificada uma razão para esses defeitos se tornarem visíveis apenas após uma diferença de 180 minutos.

- com exceção do defeito simulando os cordões de argamassa, todos os defeitos visualizados durante 0 aquecimento também o são durante 0 resfriamento, porém, em menor escala de intensidade.

- com exceção do defeito circular de $200 \mathrm{~mm}$ de diâmetro sob a cerâmica branca (seta branca na Figura 129-f) que permanece visível 16 horas após o início do resfriamento, o tempo de visualização dos demais defeitos (setas pretas na Figura 129) foi praticamente o mesmo para diferentes dimensões, formas e cor da superfície do revestimento cerâmico (Figura 129-e), ou seja, em torno de 8 horas e 30 minutos.

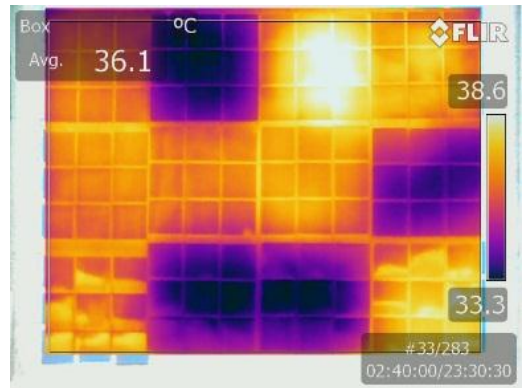

(a)

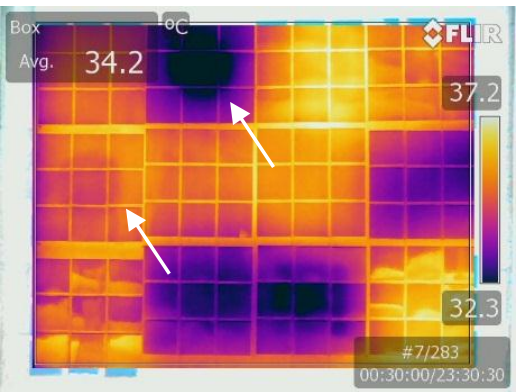

(b)

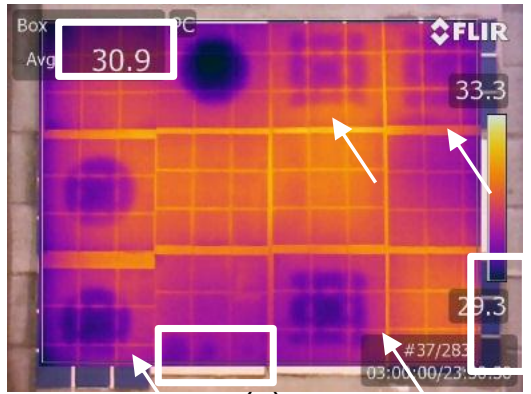

(c) 


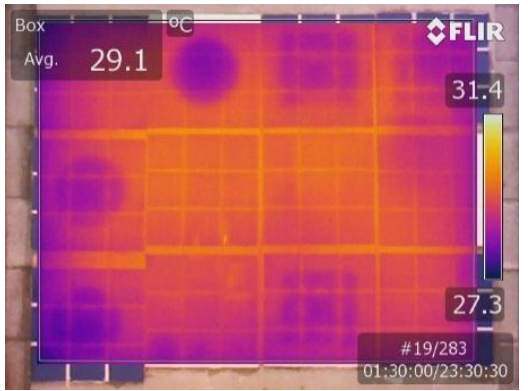

(d)

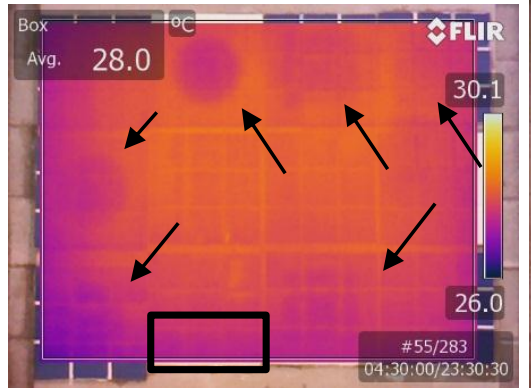

(e)

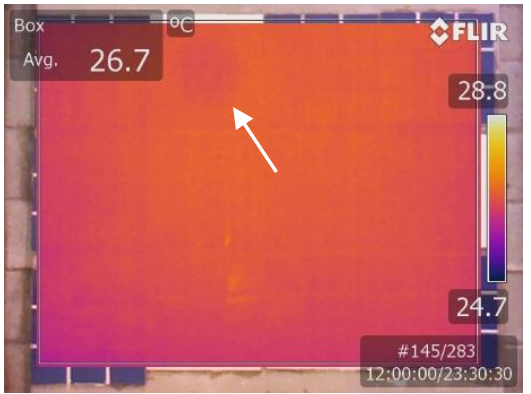

(f)

Figura 129. Termograma do painel PCO3-A após início do resfriamento: (a) 60 minutos após; (b) 90 minutos após; (c) 210 minutos após; (d) 330 minutos após; (e) 510 minutos após; (f) 960 minutos após. (Fonte: Elaborado pelo autor).

Comparativamente, os termogramas dos painéis $\mathrm{PCO}$ gerados na etapa de campo em relação aos gerados na etapa de laboratório apresentaram as mesmas diferenças observadas nos painéis $\mathrm{PCO} 2$ sob esta condição.

\section{- Sobreposição de defeitos de descolamento/vazios}

Os painéis PCO3 e PCE3 foram testados na condição de sobreposição dos defeitos de vazios de assentamento no revestimento cerâmico sobre os defeitos de descolamento na interface alvenaria/reboco (linhas pontilhadas), conforme Figura 130, Figura 131, Figura 132 e Figura 133.

Comparando as ilustrações de cada face dos painéis PCO3 e PCE3 contendo o posicionamento dos defeitos sob o reboco e dos defeitos sob o revestimento cerâmico com os termogramas registrados: logo após o aquecimento forçado com painel térmico, durante o momento registrado com menor gradiente térmico entre defeitos e não defeitos e logo após o aquecimento com sol foi possível observar alguns padrões (Figura 130, Figura 131, Figura 132 e Figura 133). São eles:

- linha pontilhada vermelha: sobreposição de defeitos visível.

- linha pontilhada branca: sobreposição de defeitos não visível.

$\mathrm{Na}$ composição de sobreposição de defeitos no painel PCO3-A (Figura 130), imediatamente após o aquecimento com painel térmico (Figura 131-a) foi possível observar alguns defeitos de forma discreta sob o revestimento cerâmico.

Durante o período de resfriamento (Figura 131-b) no qual os defeitos sob a cerâmica estão passando da condição de maior para menor temperatura em relação às áreas 
sem defeito é possível visualizar mais defeitos sob o reboco, sendo os três com a melhor definição de forma e de dimensões representados pela seta branca; no entanto, nessa fase não é possível identificar ou distinguir a forma e a dimensão dos defeitos sob a cerâmica.

Durante o aquecimento ao sol (condição testada apenas para o painel PCO3-A), foi possível identificar os mesmos defeitos da condição de menor gradiente térmico registrado, porém ocorreu a inversão dos defeitos com melhor definição de forma e de dimensão (setas brancas na Figura 131-c).

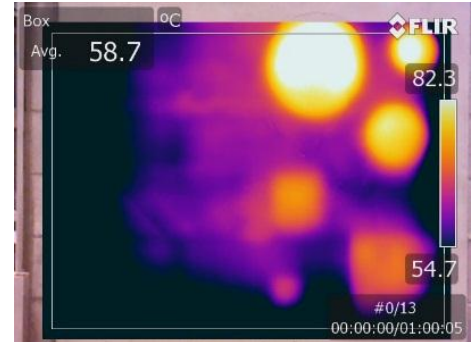

(a)

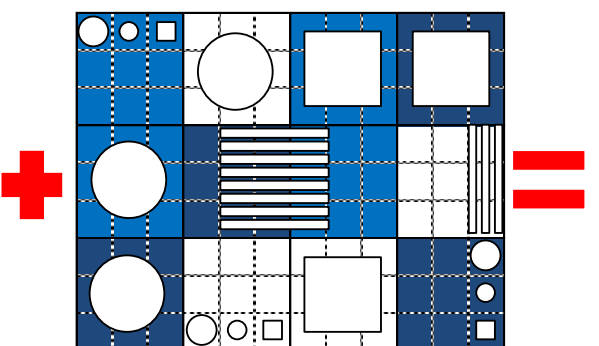

(b)

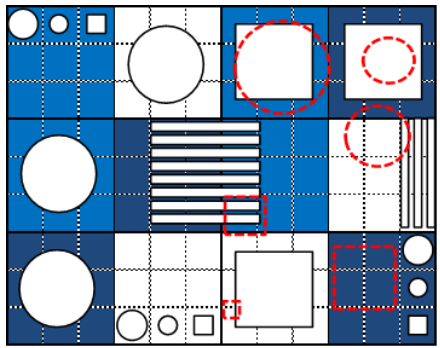

(c)

Figura 130. Painel PCO3-A: (a) Termograma dos defeitos de descolamento sob o reboco (b) Ilustração dos defeitos sob revestimento cerâmico; (c) llustração da sobreposição de defeitos. (Fonte: Elaborado pelo autor).

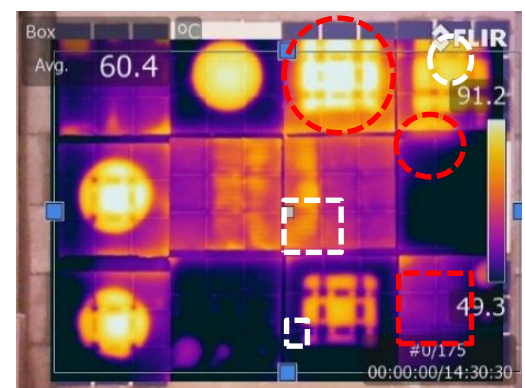

(a)

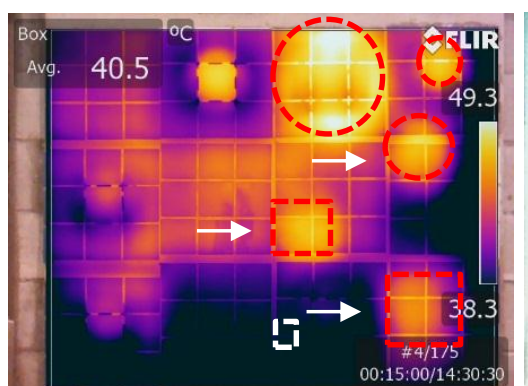

(b)

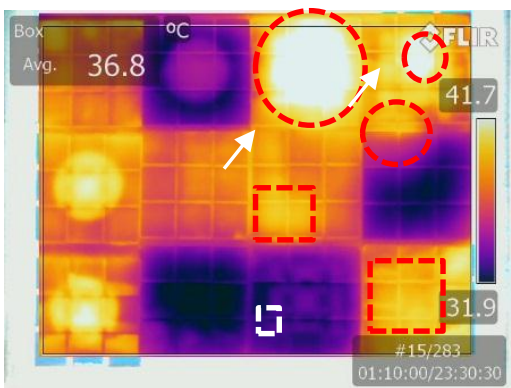

(c)

Figura 131. Sobreposição de defeitos no painel PCO3-A: (a) Imediatamente após o aquecimento com painel térmico; (b) Menor gradiente térmico registrado durante resfriamento ambiente; (c) Durante aquecimento ao sol. (Fonte: Elaborado pelo autor).

Visualizada a composição de sobreposição de defeitos no painel PCO3-B (Figura 132), imediatamente após o aquecimento com painel térmico (Figura 133-a) não foi possível observar defeitos sob o reboco.

A melhor condição ocorreu nomomento de menor gradiente térmico registrado no resfriamento (Figura 133-b) sendo possível visualizar os dois defeitos sob o reboco, entretanto, apenas um com boa definição de forma e dimensões representado pela seta branca. 
Durante o resfriamento forçado (Figura 133-c) foi possível identificar apenas o defeito circular de $150 \mathrm{~mm}$ sob o reboco localizado no canto inferior do painel (círculo vermelho).

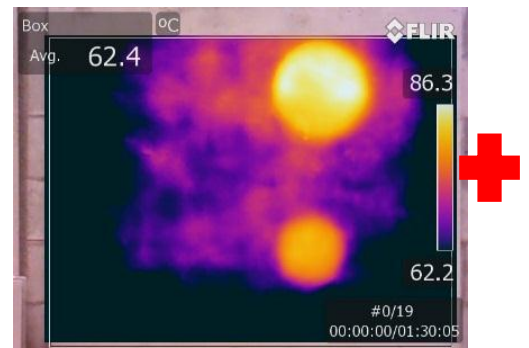

(a)

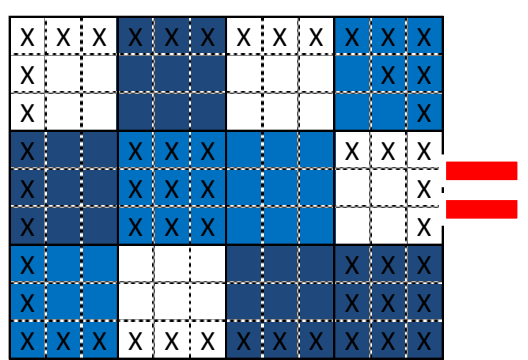

(b)

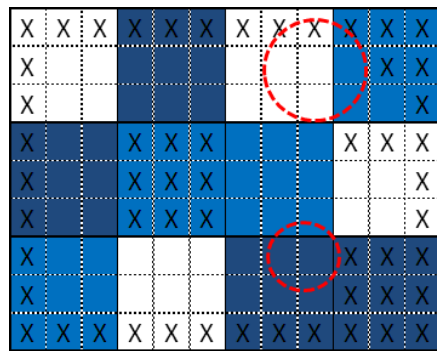

(c)

Figura 132. Painel PCO3-B: (a) Termograma dos defeitos de descolamento sob o reboco (b) llustração dos defeitos sob revestimento cerâmico; (c) llustração da sobreposição de defeitos. (Fonte: Elaborado pelo autor).

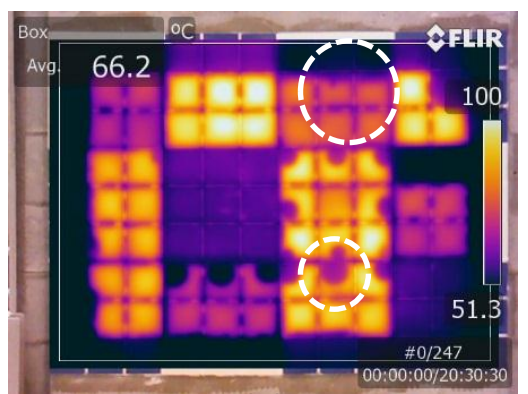

(a)

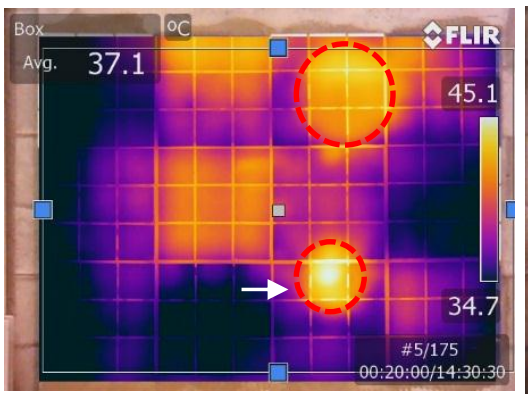

(b)

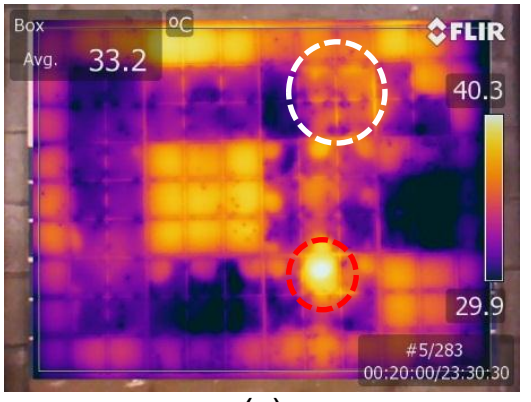

(c)

Figura 133. Sobreposição de defeitos no painel PCO3-B: (a) Imediatamente após o aquecimento com painel térmico; (b) Menor gradiente térmico registrado durante resfriamento ambiente; (c) Durante resfriamento forçado com água. (Fonte: Elaborado pelo autor).

Visualizada a composição de sobreposição de defeitos no painel PCE3-A (Figura 134), imediatamente após o aquecimento com painel térmico (Figura 135-a), foi possível observar apenas o defeito retangular sob o reboco no canto inferior direito do painel (quadrado vermelho), no entanto, numa condição de não conhecimento prévio sobre o defeito, essa constatação seria facilmente confundida com os demais defeitos sob o revestimento cerâmico.

Novamente a melhor condição ocorreu no momento de menor gradiente térmico registrado no resfriamento (Figura 135-b) sendo possível visualizar os dois defeitos sob o reboco, porém, não houve nem um que tivesse com boa definição de forma e dimensões. Pela primeira vez o menor defeito quadrado exerce influência na temperatura da superfície da cerâmica (seta branca na Figura 135-b). 
Durante o resfriamento forçado não foi possível identificar defeitos sobrepostos ou sob o reboco, apenas os defeitos sob a cerâmica.

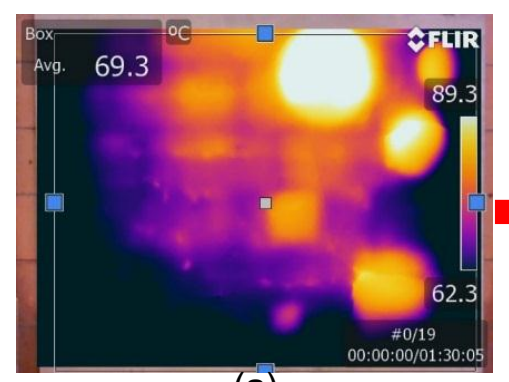

(a)

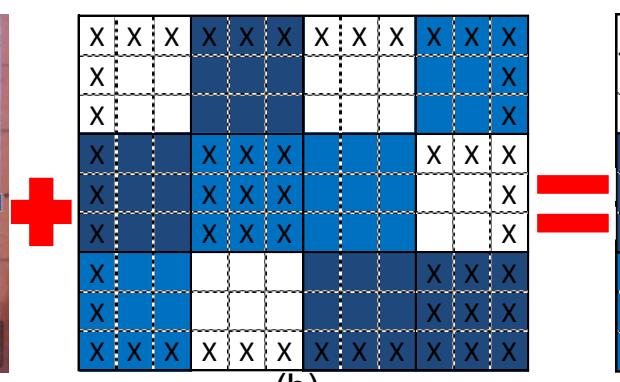

(b)

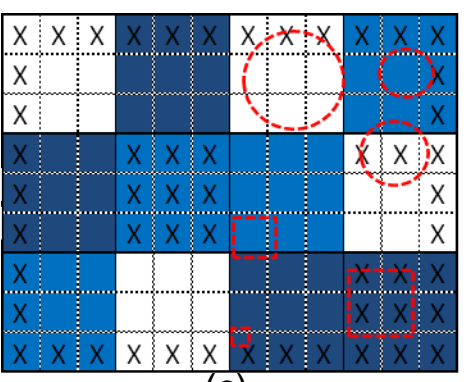

(c)

Figura 134. Painel PCE3-A: (a) Termograma dos defeitos de descolamento sob o reboco (b) llustração dos defeitos sob revestimento cerâmico; (c) llustração da sobreposição de defeitos. (Fonte: Elaborado pelo autor).

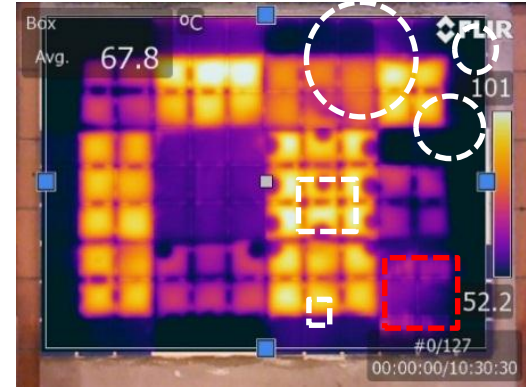

(a)

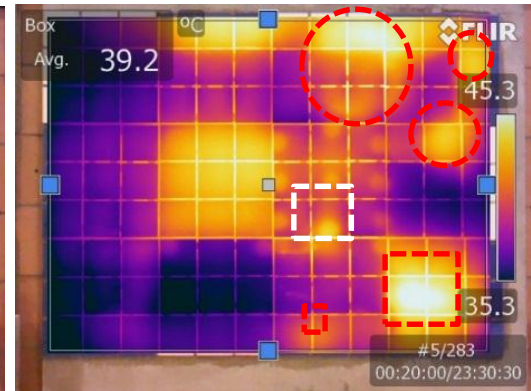

(b)

Figura 135. Sobreposição de defeitos no painel PCE3-A: (a) Imediatamente após o aquecimento com painel térmico; (b) Menor gradiente térmico registrado durante resfriamento ambiente. (Fonte: Elaborado pelo autor).

Visualizada a composição de sobreposição de defeitos no painel PCE3-B (Figura 136), imediatamente após o aquecimento com painel térmico (Figura 137-a), foi possível observar apenas o defeito retangular sob o reboco no canto inferior direito do painel, no entanto, numa condição de não conhecimento prévio sobre o defeito, essa constatação seria facilmente confundida com os demais defeitos sob o revestimento cerâmico.

Novamente a melhor condição ocorreu no momento de menor gradiente térmico registrado no resfriamento (Figura 137-b) sendo possível visualizar os dois defeitos sob o reboco, porém não restou um com boa definição de forma e dimensões. Pela primeira vez o menor defeito quadrado exerce influência na temperatura da superfície da cerâmica (seta branca na Figura 137-b).

Durante o resfriamento forçado não foi possível identificar defeitos sobrepostos ou sob o reboco, apenas os defeitos sob a cerâmica. 


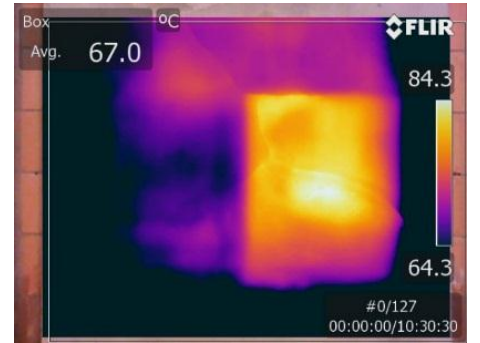

(a)

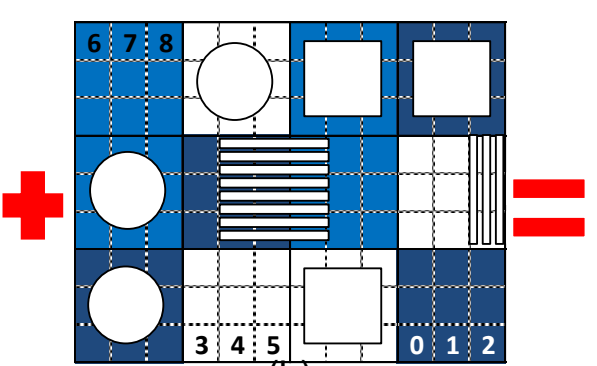

(b)

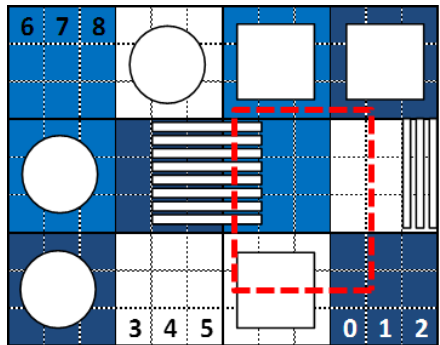

(c)

Figura 136. Painel PCE3-B: (a) Termograma dos defeitos de descolamento sob o reboco (b) llustração dos defeitos sob revestimento cerâmico; (c) llustração da sobreposição de defeitos. (Fonte: Elaborado pelo autor).

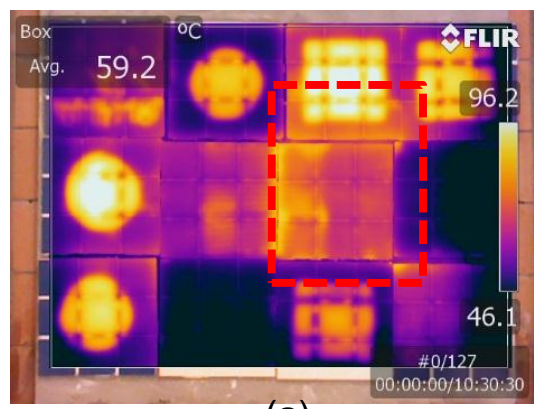

(a)

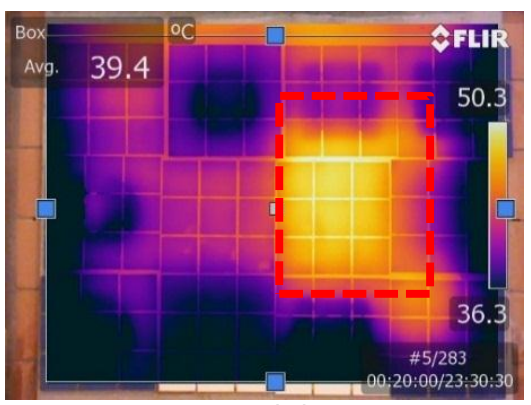

(b)

Figura 137. Sobreposição de defeitos no painel PCE3-B: (a) Imediatamente após o aquecimento com painel térmico; (b) Menor gradiente térmico registrado durante resfriamento ambiente; (c) Durante resfriamento forçado com água. (Fonte: Elaborado pelo autor).

Pode-se concluir que os defeitos sob o reboco são visíveis com melhor clareza nas condições em que os defeitos sob o revestimento cerâmico estão menos visíveis (condição de menor gradiente térmico capturado pelo equipamento somada à condição de aquecimento ao sol).

\subsubsection{Defeitos de descolamento/vazios in situ: Termografia como ferramenta de diagnóstico de descolamento cerâmico em fachada}

Os defeitos foram previamente identificados por meio de mapeamento manual das regiões de defeito (setas vermelhas na Figura 138-a) por intermédio do "teste de percussão", nome dado no meio técnico para a inspeção manual através de leves impactos com martelo de pequeno porte sobre o revestimento investigado para determinar auditivamente os trechos do revestimento com som cavo. Apesar de o ensaio por percussão ser considerada uma técnica não destrutiva, depende de uma estrutura de acesso à fachada, normalmente composta por balancim ou "cadeirinha". 
Comparando a área ampliada da fachada contendo parte do mapeamento das regiões de desplacamento de pastilhas (retângulos vermelhos na Figura 138-b e Figura 139b) com os termogramas contendo as áreas do revestimento pastilhado com valores de temperatura mais elevados durante aquecimento ao sol (retângulo vermelhos na Figura 138-c e Figura 139-c), observa-se que as regiões são coincidentes.

Algumas regiões de defeito foram identificadas nos termogramas, mas não estão presentes no mapeamento (círculos pretos na Figura 138-c e Figura 139-c), representando pontos de atenção, já que em alguns desses pontos foi possível comprovar a existência dos defeitos através de imagens digitais feitas com câmera de alta resolução (Figura 139-d).

Essas regiões com maiores temperaturas ocorrem porque 0 ar existente entre a cerâmica e o reboco age como uma barreira térmica causando um atraso na refrigeração.

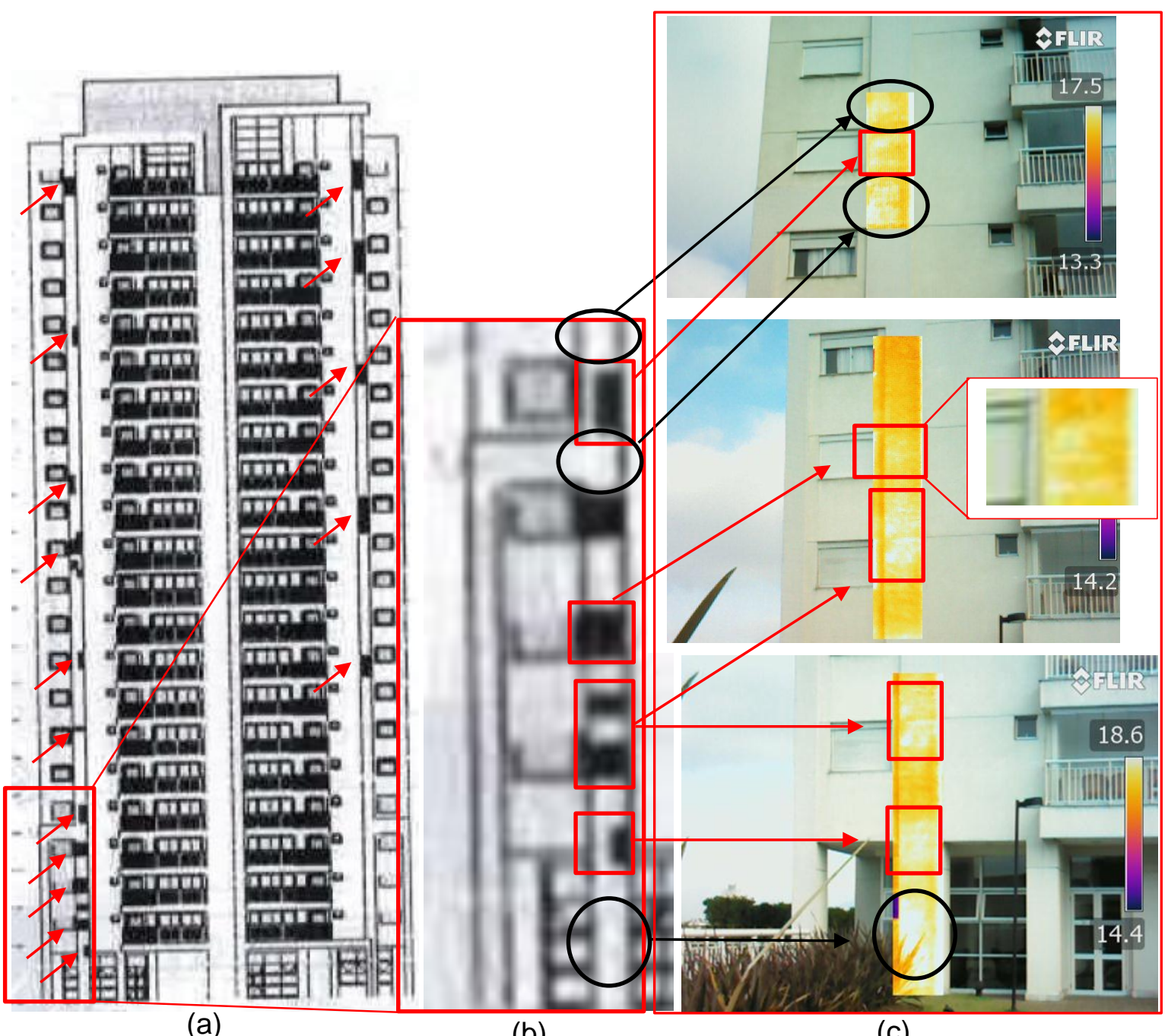

(a)

(b)

(c) 
Figura 138. (a) Imagem da fachada com defeitos mapeados; (b) Ampliação de parte da fachada com defeitos; (c) Termogramas dos defeitos. (Fonte: Elaborado pelo autor).

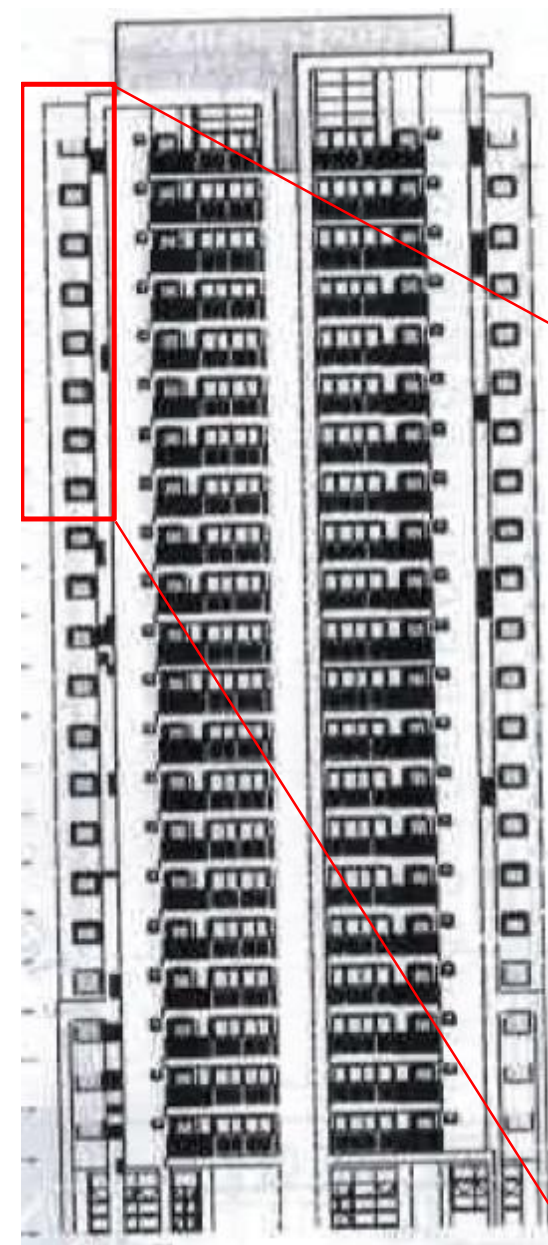

(a)

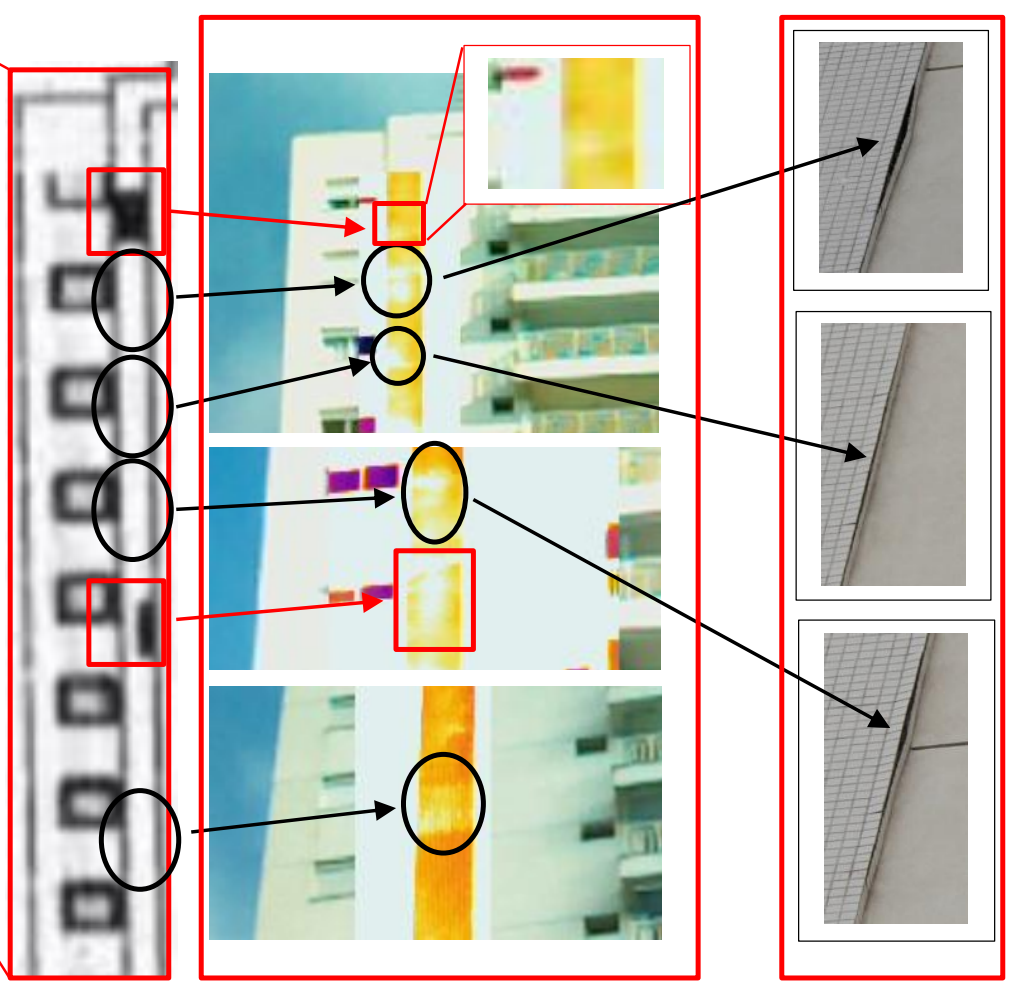

(c) (d)

Figura 139. (a) Imagem da fachada com defeitos mapeados; (b) Ampliação de parte da fachada com defeitos; (c) Termogramas dos defeitos; (d) Imagem digital dos defeitos.

(Fonte: Elaborado pelo autor).

\subsubsection{Termografia como ferramenta de controle de execução/recuperação de defeitos de desplacamento em revestimento cerâmico de fachada}

A termografia foi testada também como ferramenta de controle de execução/recuperação em fachadas durante resfriamento à sombra. Nessa condição, o termograma mostra:

- as regiões recém recuperadas apresentaram temperaturas menores que a área ao redor devido à influência da temperatura mais baixa da argamassa úmida utilizada no assentamento do revestimento (setas brancas na Figura 140). 


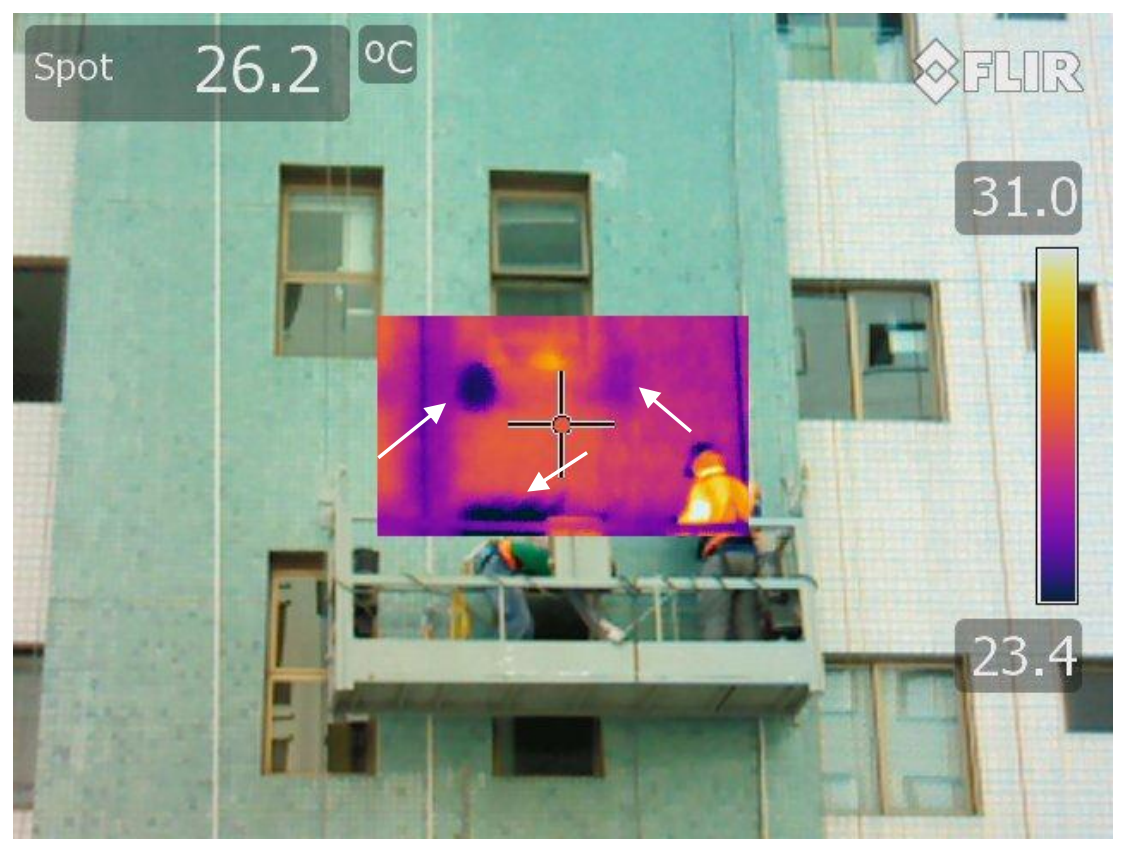

Figura 140. Termograma de área recém recuperada (setas brancas). (Fonte: Elaborado pelo autor).

- as regiões recuperadas em dias anteriores apresentaram temperaturas maiores que a área seca ao redor devido à maior capacidade térmica da água ainda presente na argamassa em relação à área seca. Esse comportamento permitiu identificar e controlar pequenas áreas de intervenção (setas brancas na Figura 141) até fachadas inteiras (Figura 142-a e Figura 142-b).

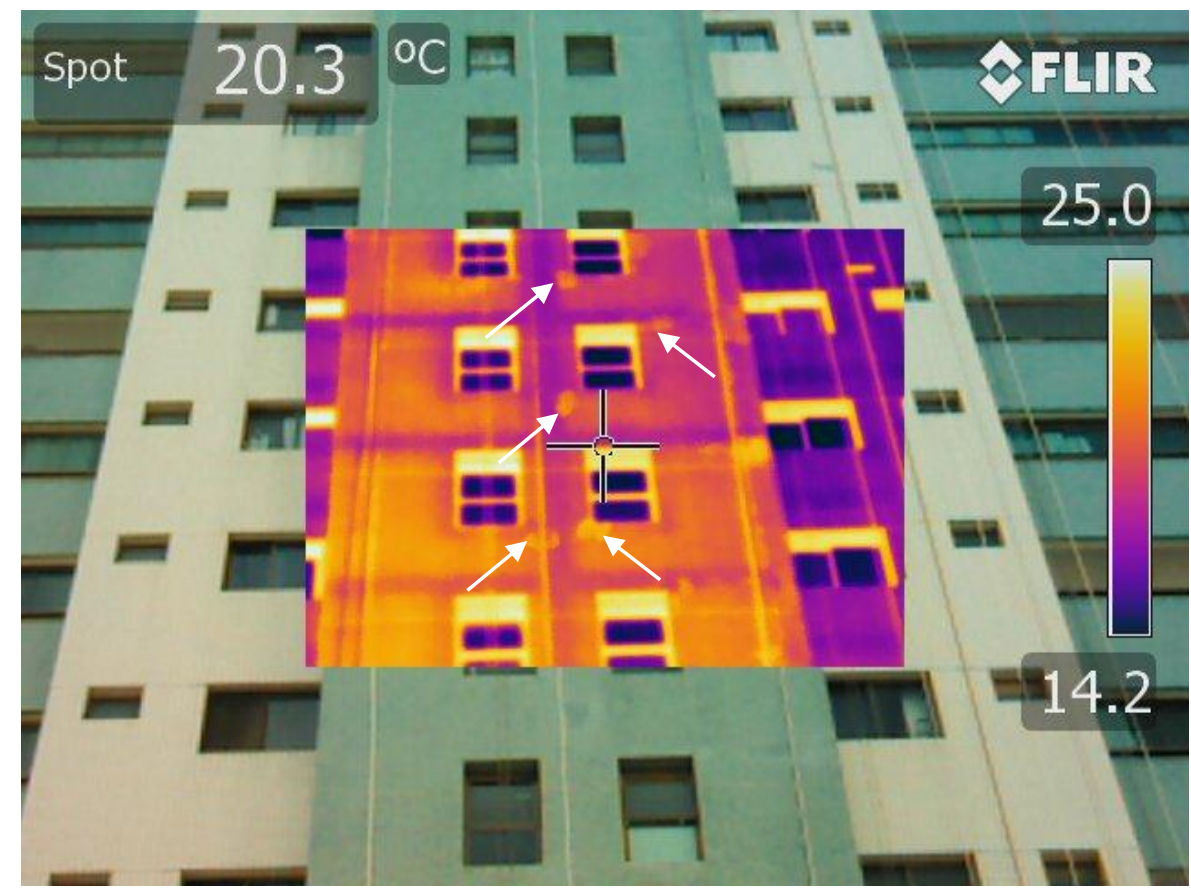

Figura 141. (a) Termograma de fachada com regiões recuperadas. (Fonte: Elaborado pelo autor). 


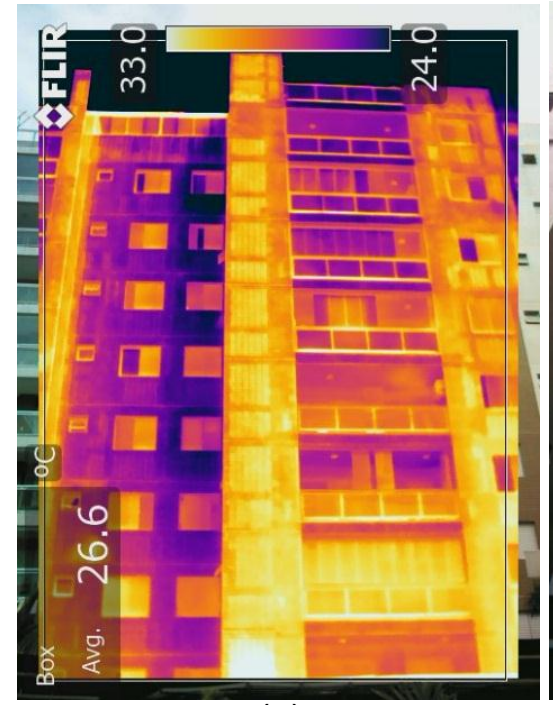

(a)

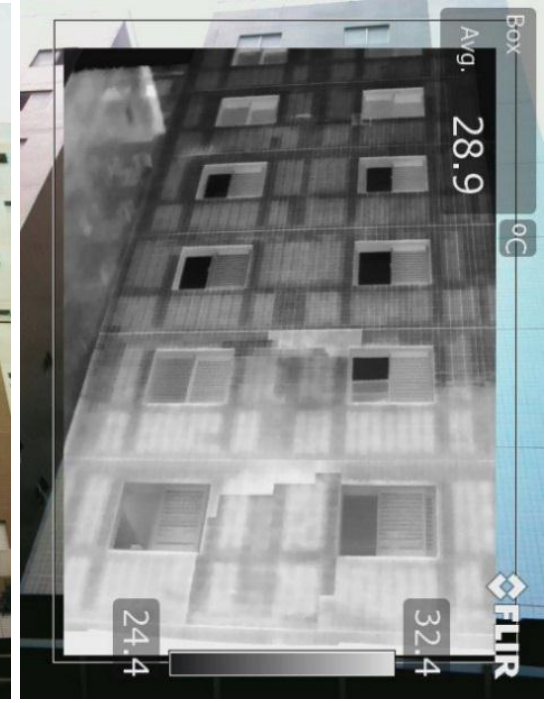

(b)

Figura 142. Termograma de fachadas após recuperação de descolamento de revestimento cerâmico: (a) em escala de cor "iron"; (b) em escala cinza. (Fonte: Elaborado pelo autor).

Regiões ainda não recuperadas apresentam temperatura mais alta em relação às regiões sem defeito, conforme destacado no círculo branco na Figura 143.

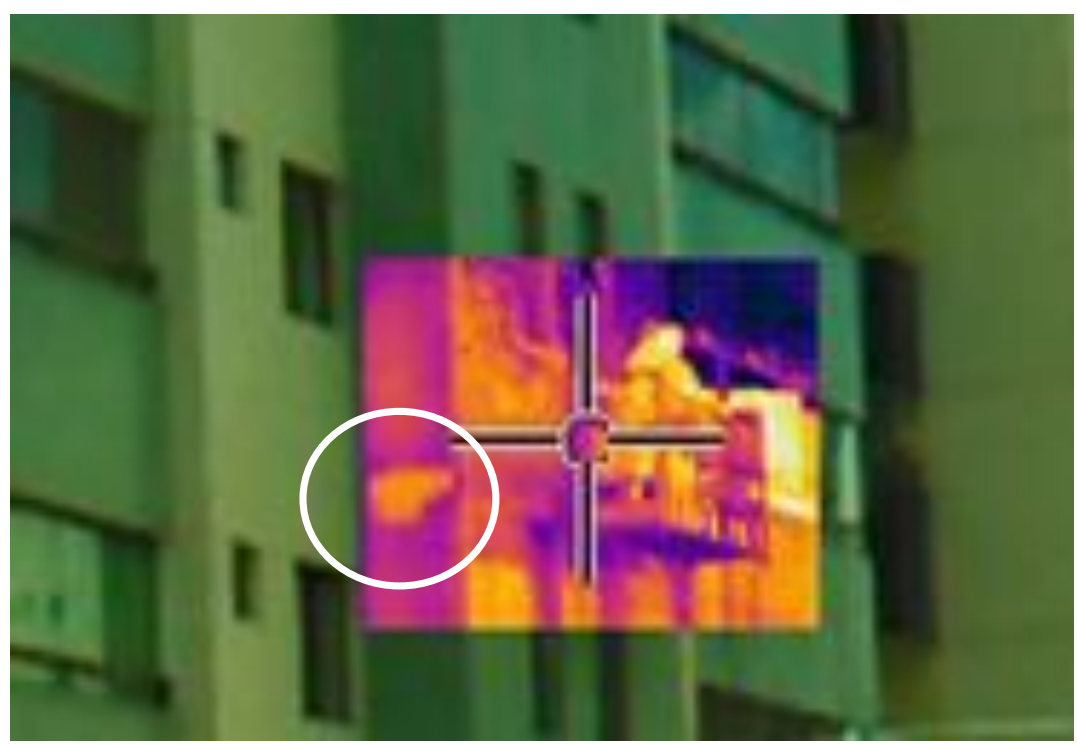

Figura 143. Termograma de região ainda não recuperada. (Fonte: Elaborado pelo autor).

\subsubsection{Influências do processo de uso da tecnologia de termografia em ambiente aberto}

Diferentes situações podem gerar interferências que alteram a condição natural da superfície em análise, levando a interpretações equivocadas dos termogramas, dessa forma, foram analisadas algumas condições para melhor interpretação dos termogramas: 
- Posicionamento em relação à fachada e ângulo de registro do termograma

No caso de fachadas revestidas com cerâmica o mais comum são os reflexos sobre a superfície do revestimento gerados pelo sol (Figura 144-a), pela arquitetura da própria edificação ou por edificações vizinhas.

Dessa forma, definida a fachada a ser inspecionada (Figura 144-a), imagens termográficas realizadas de diferentes ângulos (Figura 144-b e c), distâncias (Figura 144-d) e horários podem reduzir ou eliminar essas interferências, indicando corretamente a presença de áreas de cerâmicas, conforme ilustrado pelas setas brancas nas Figura 144-b e Figura 144-c.

Com o recurso do drone é possível aproximar-se da região com defeito, obtendo imagens com melhor resolução (retângulos brancos na Figura 144-d), que melhoram a assertividade do diagnóstico.

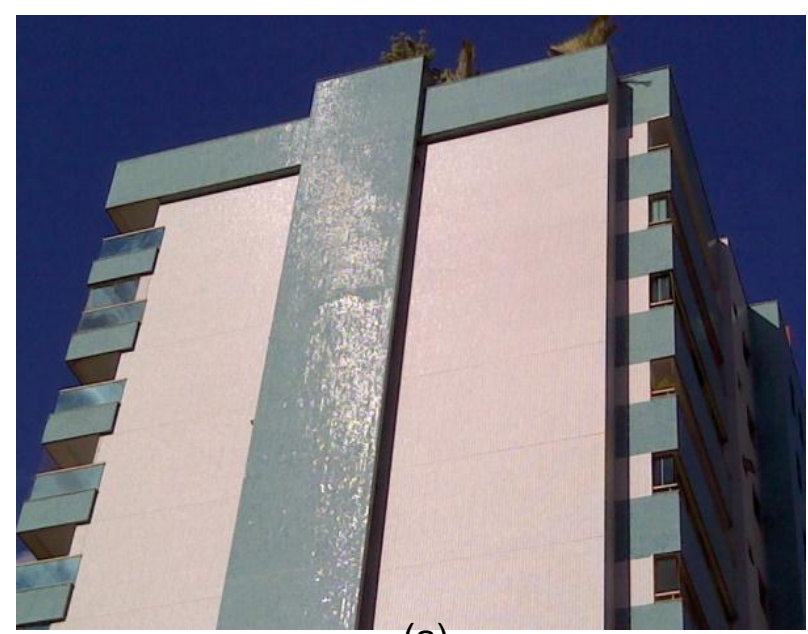

(a)

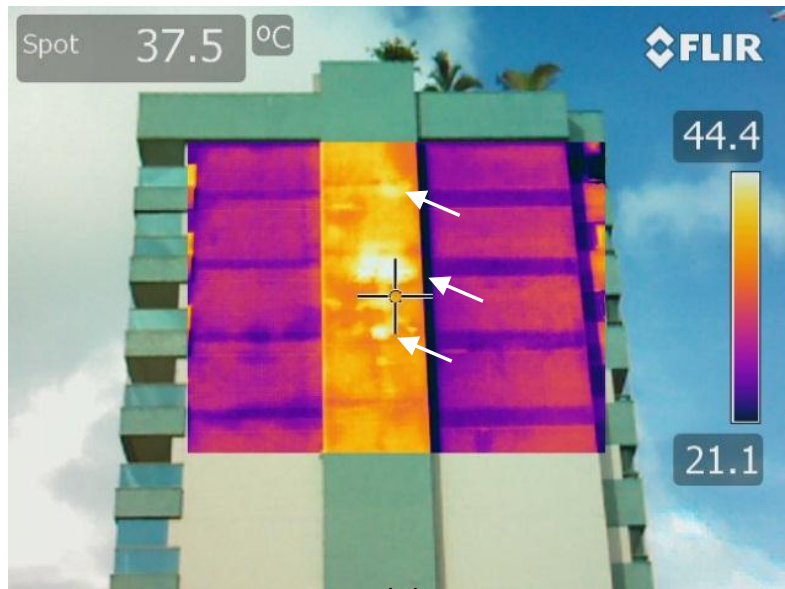

(c)

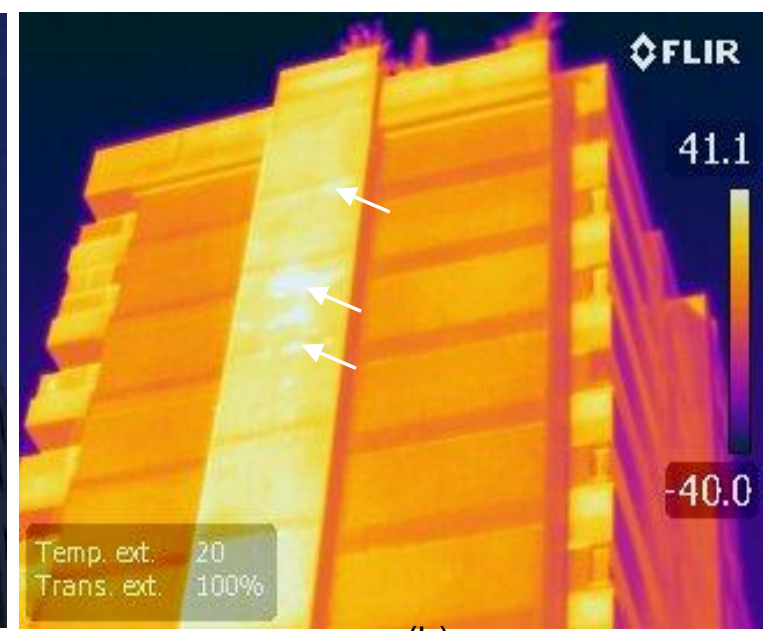

(b)

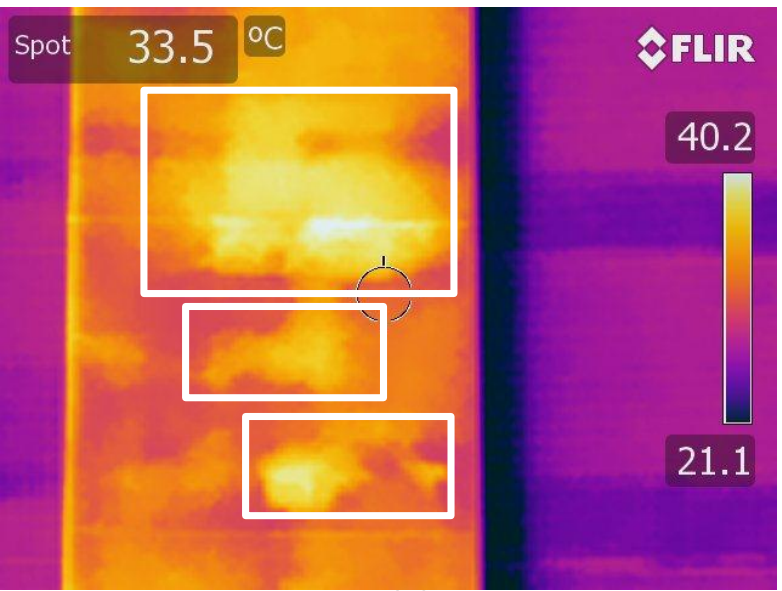

(d)

Figura 144. (a) Imagem digital da fachada avaliada; (b) Termograma da fachada avaliada;

(c) Termograma da fachada avaliada registrado de outro ângulo; (d) Termograma dos defeitos registrado com drone. (Fonte: Elaborado pelo autor). 


\section{- Tamanho da área analisada vs ângulo de registro do termograma}

Área muito extensa captada pelo termovisor composta por elementos com grandes diferenças de temperatura vs ângulo do equipamento em relação à fachada influenciam no valor de temperatura registrada em cada ponto, impactando o contraste térmico e, consequentemente, a visualização dos defeitos. Assim, o ajuste do foco e da amplitude térmica para ressaltar o defeito em cada área analisada pode fazer a diferença entre identificar ou não o defeito (retângulos vermelhos na Figura 145-a e Figura 145-b).

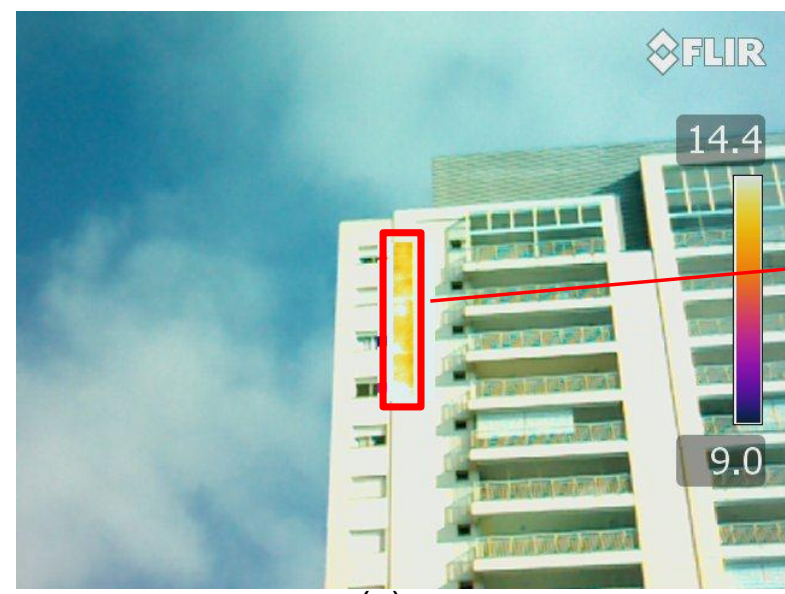

(a)

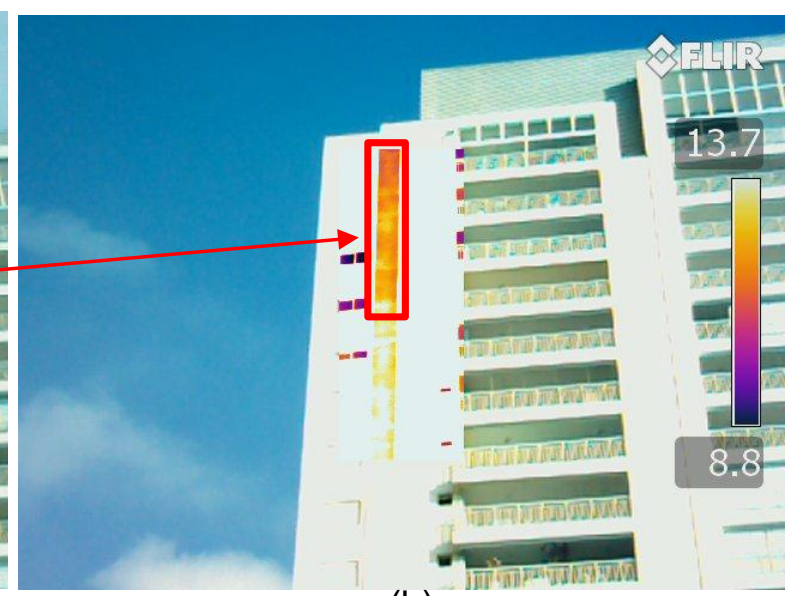

(b)

Figura 145. (a) Termograma com melhor ajuste de foco para identificação dos defeitos; (b) termograma sem ajuste correto de foco. (Fonte: Elaborado pelo autor).

\section{- Vizinhança e arquitetura do edifício em análise}

Diferentes elementos ao redor do edifício (outros edifícios, vidro, revestimentos cerâmicos, painéis metálicos) podem gerar áreas de sombra (contorno branco na Figura 146) ou reflexo sobre a fachada em análise, podendo confundir a interpretação dos termogramas. 


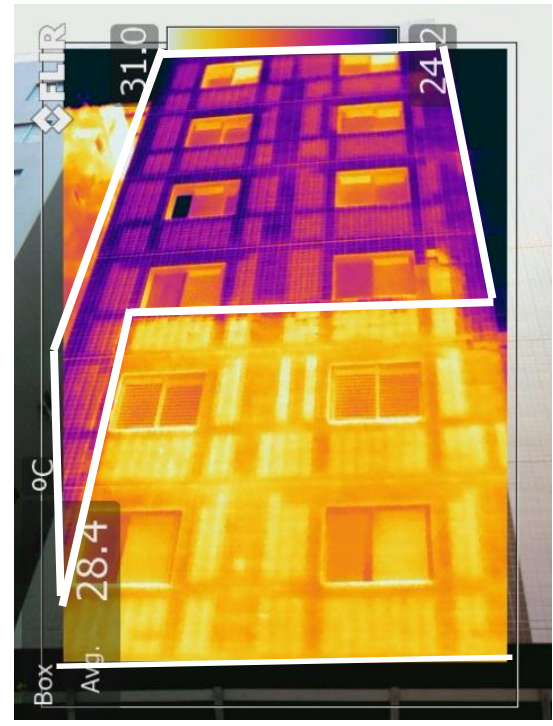

Figura 146. Fachada com área restrita de incidência solar (quadro branco) devido ao sombreamento causado por prédios vizinhos. (Fonte: Elaborado pelo autor).

Características arquitetônicas, como recortes da fachada, associadas ao tipo de revestimento também podem gerar áreas de reflexão e sombreamento (Figura 147-a) que alteram os termogramas. Os reflexos normalmente possuem bordas bem definidas e não possuem gradiente térmico (Figura 147-b).

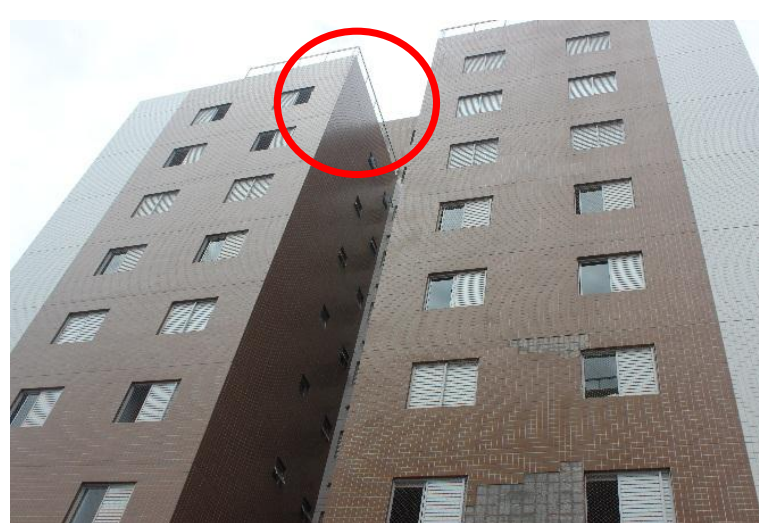

(a)

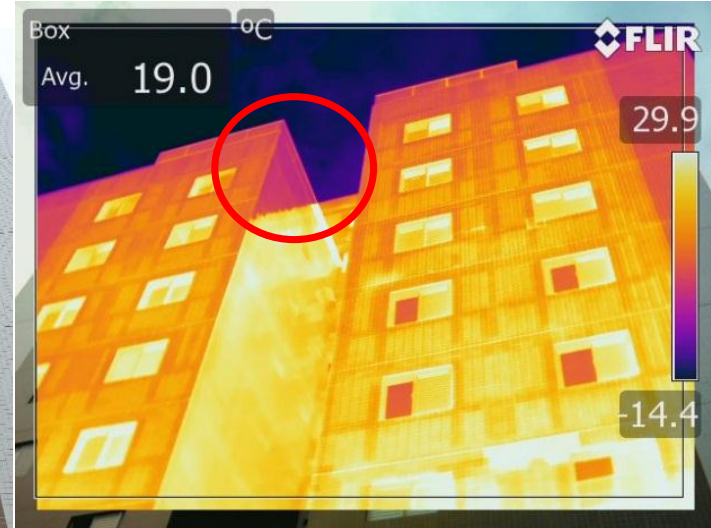

(b)

Figura 147. (a) Detalhe da fachada sob influência de reflexão devido à interferência da arquitetura (face oposta) (b) Influência da reflexão na temperatura superficial. (Fonte:

Elaborado pelo autor).

\section{- Tempo de exposição ao sol}

O aumento do tempo de exposição da fachada ao sol leva à redução da diferença de temperatura devido à tendência ao menor gradiente térmico entre as regiões com e sem defeitos (Figura 148-a). Dessa forma, torna-se mais difícil a identificação do defeito (Figura 148-b). 


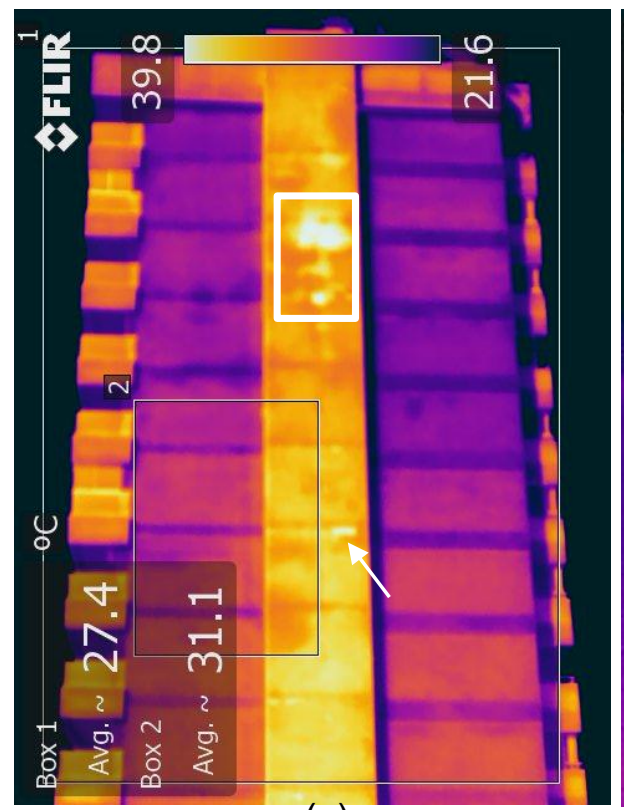

(a)

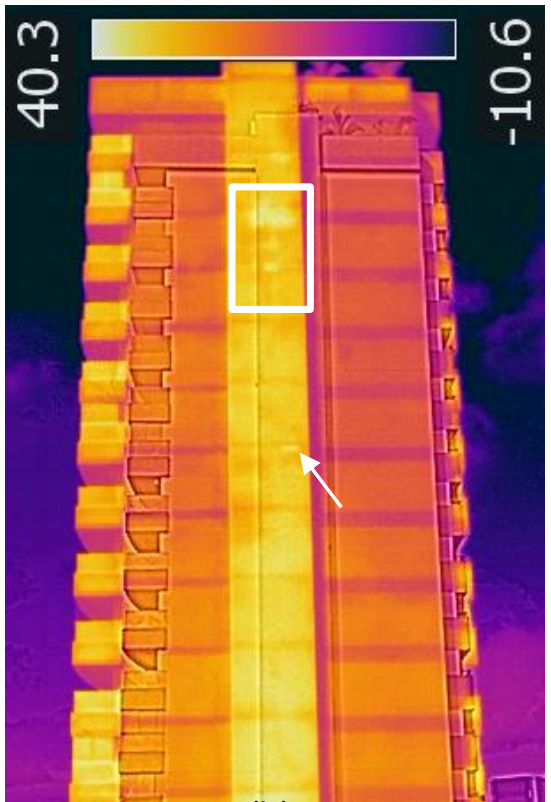

(b)

Figura 148. (a) Fachada com elevado gradiente térmico entre região com e sem defeito; (b) Mesma fachada em condição de menor gradiente térmico. (Fonte: Elaborado pelo autor).

\subsubsection{Influência dos recursos do equipamento e do software na} identificação/visualização dos defeitos de desplacamento em fachada.

\section{- Amplitude térmica}

O uso da amplitude de temperatura correta permite identificar com precisão as áreas de descolamento, isolando a região com defeito a partir da definição de uma faixa mais estreita de temperatura máxima e mínima (Figura 149-a; Figura 149-b).

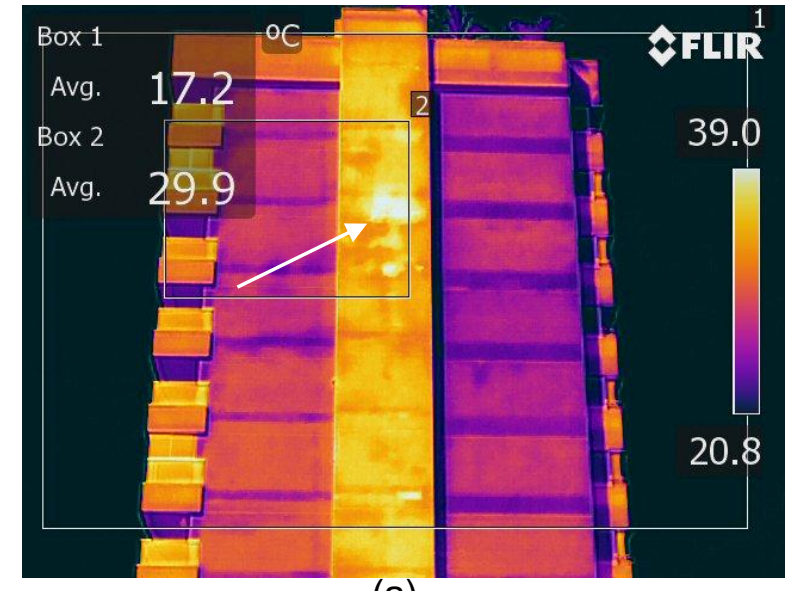

(a)

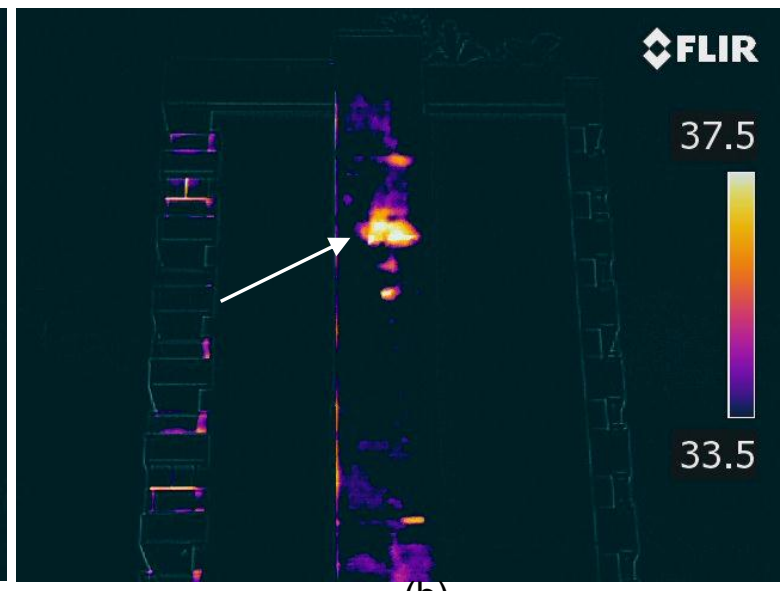

(b)

Figura 149. (a) Termograma do defeito de descolamento na fachada avaliada; (b) Isolamento do defeitos com uso de amplitude de temperatura específica ao defeito. (Fonte: Elaborado pelo autor). 


\section{- Zoom}

O recurso do zoom pode ser utilizado para registrar os detalhes dos defeitos através do aumento da imagem eletronicamente (Figura 150-a e Figura 150-b), porém, apesar de não alterar a medição, há uma perda de resolução da imagem térmica.

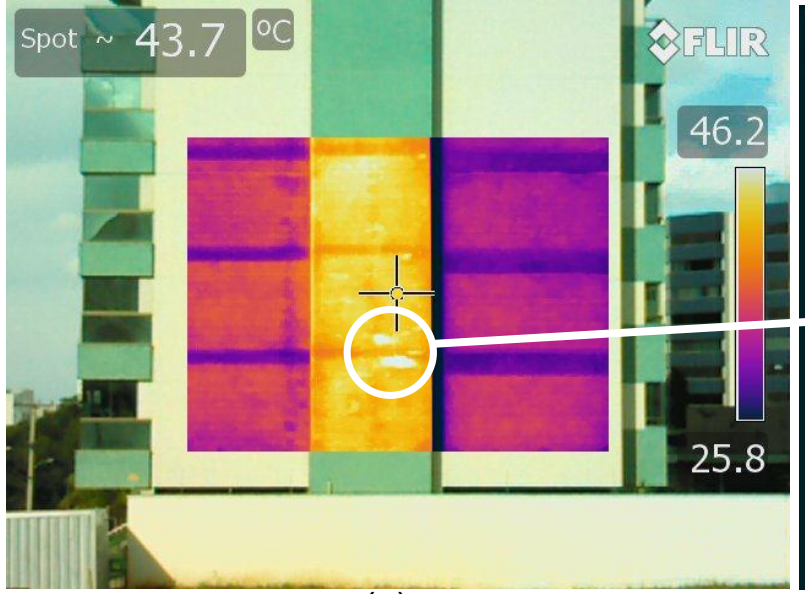

(a)

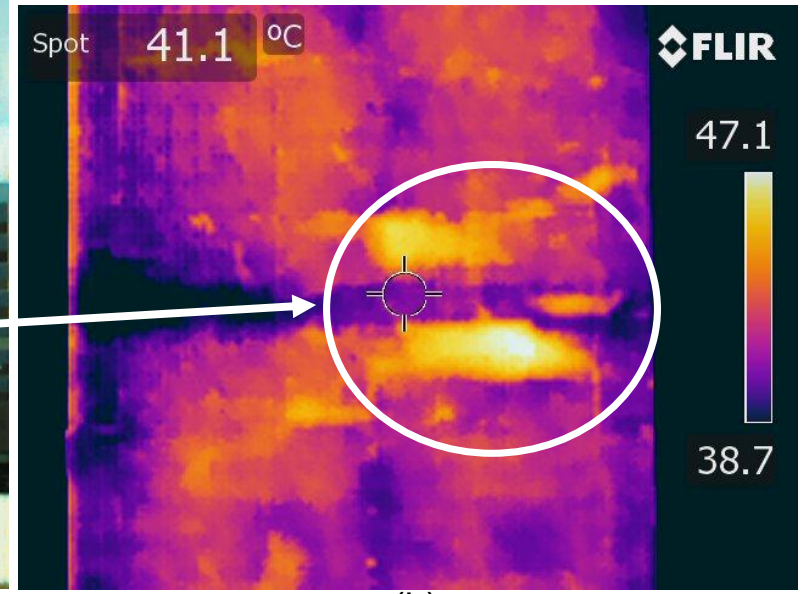

(b)

Figura 150. (a) Termograma do defeito de desplacamento na fachada avaliada; (b) Zoom dos defeitos. (Fonte: Elaborado pelo autor).

\section{- Amplitude térmica e zoom simultaneamente (Figura 151)}

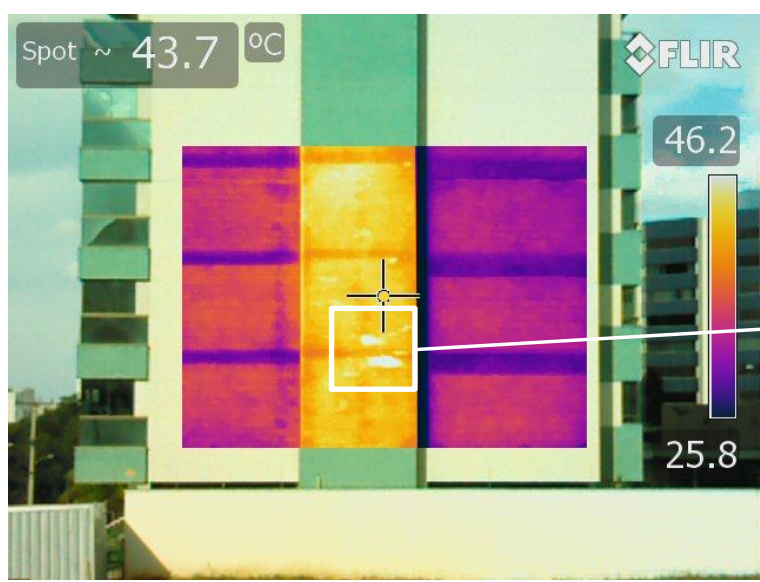

(a)

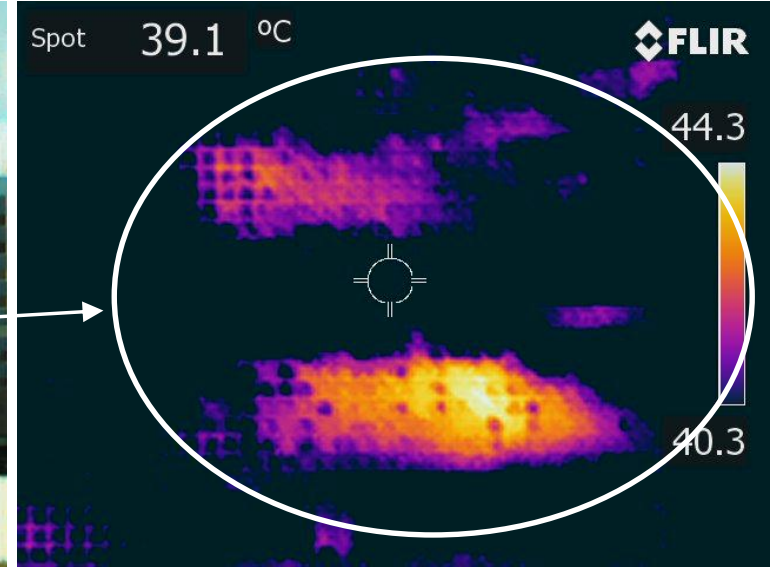

(b)

Figura 151. (a) Termograma do defeito de desplacamento na fachada avaliada; (b) Isolamento dos defeitos com uso de faixa de temperatura específica em imagem ampliada com zoom. (Fonte: Elaborado pelo autor).

\section{- Paleta de cores}

O uso de paleta com diferentes contrastes de cores pode melhorar/destacar a visualização dos defeitos (Figura 152). 


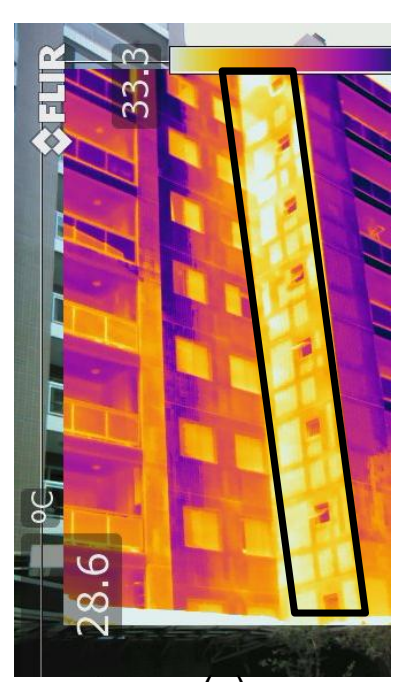

(a)

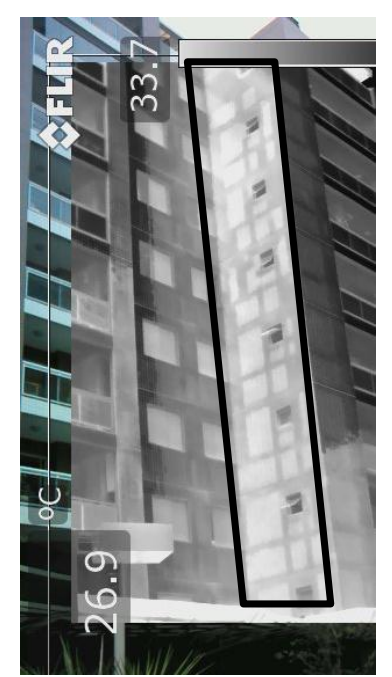

(b)

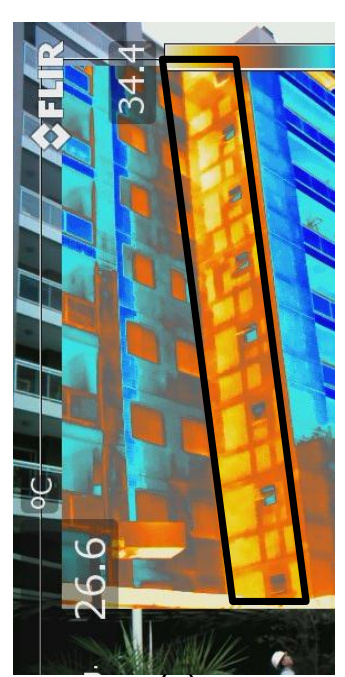

(c)

Figura 152. Termograma de fachada recuperada com diferentes paletas de cores: (a) Paleta de cor "iron"; (b) Paleta de cor "cinza"; (c) Paleta de cor "ice". (Fonte: Elaborado pelo autor).

\subsubsection{Defeitos de fissuras nos painéis}

A dificuldade de identificação das fissuras pode ser minimizada potencializando o gradiente térmico, criando condições mais favoráveis de leitura. $\mathrm{Na}$ etapa de laboratório isso foi realizado utilizando ciclos de aquecimento e ciclos de aquecimento e resfriamento com água nos painéis PCE2 e PCO2. Após o ciclo de aquecimento as microfissuras não foram identificadas, sendo possível identificar apenas os defeitos de desplacamento criados sob o reboco (Figura 153); já através do ciclo de aquecimento e resfriamento com água as microfissuras (Figura 154-a) foram identificadas com elevado nível de detalhes, imediatamente após o resfriamento, mesmo estando sobrepostas aos defeitos sob o reboco (Figura 154-b).

Os termogramas registrados cinco (Figura 154-c), dez (Figura 155-a), quinze (Figura 155-b) e vinte (Figura 155-c) minutos após o resfriamento mostram uma redução gradativa na visualização das fissuras devido ao processo de redução do gradiente térmico entre as fissuras e o reboco ao redor, ficando destacados apenas os defeitos sob o reboco. Pórem, ajustando a câmera térmica, foi possível capturar as fissuras 45, 90, 100 e 190 minutos após o incício do resfriamento (Figura 156-a, Figura 156-b, Figura 157-a e Figura 157-b).

Para isso, a presença de umidade nas fissuras associada às condições de incidência de radiação sobre a zona fissurada representa uma condição importante para usos da tecnologia na identificação desse tipo de defeito. 


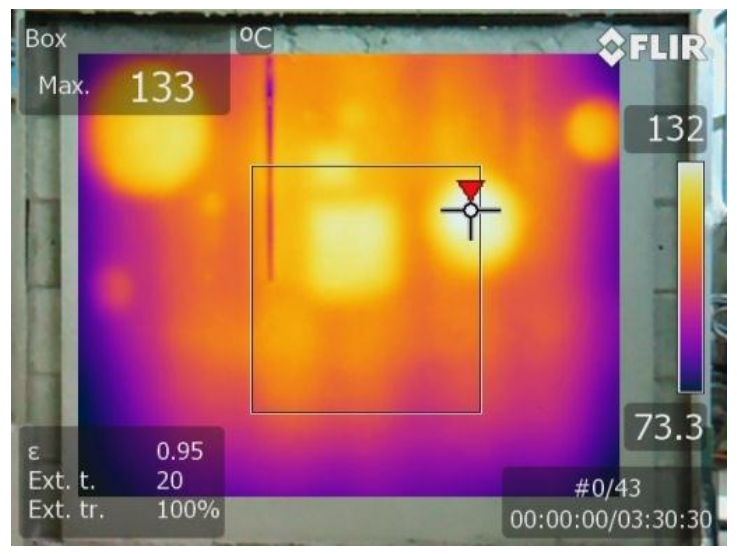

Figura 153. Termograma do painel PCO2-A imediatamente após o aquecimento. (Fonte: Elaborado pelo autor).

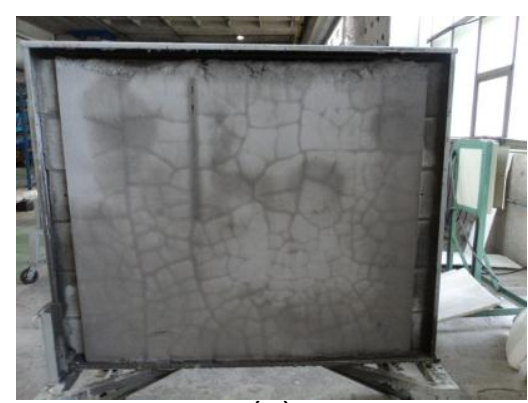

(a)

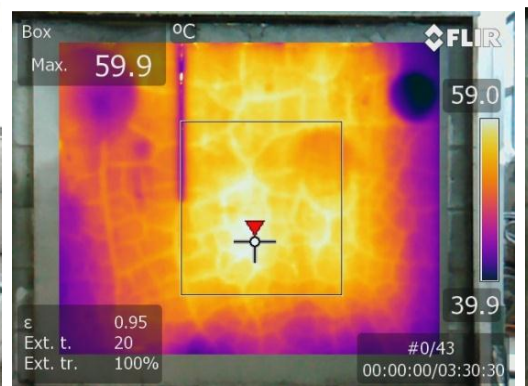

(b)

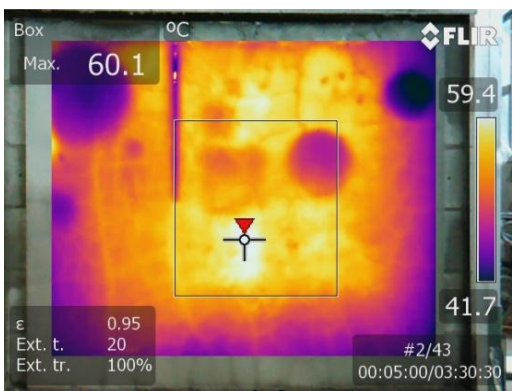

(c)

Figura 154. Painel PCO2-A: (a) Imagem digital após resfriamento com água; (b) Termograma imediato após o primeiro resfriamento com água; (c) Termograma cinco minutos após o primeiro resfriamento com água. (Fonte: Elaborado pelo autor).

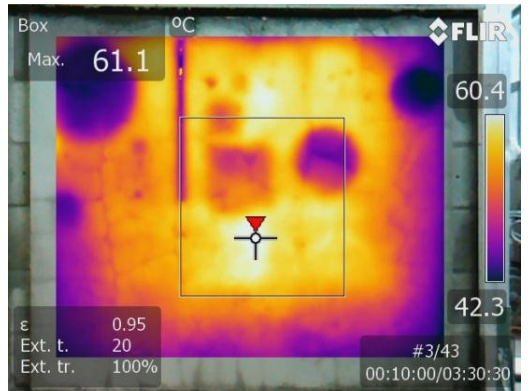

(a)

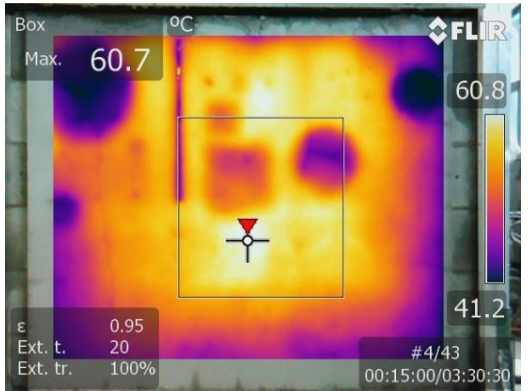

(b)

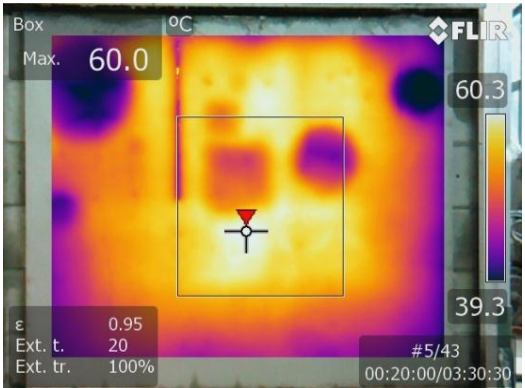

(c)

Figura 155. Termogramas do Painel PCO2-A: (a) dez minutos após o resfriamento com água; (b) quinze minutos após o resfriamento com água; (c) vinte minutos após o resfriamento com água. (Fonte: Elaborado pelo autor). 


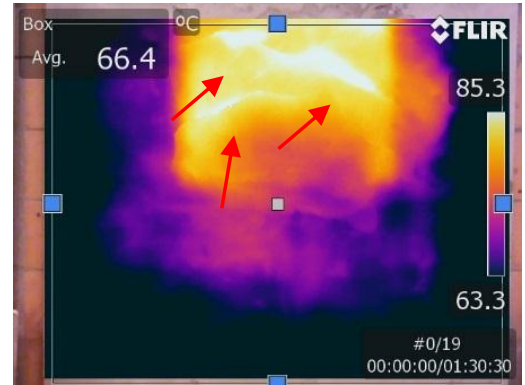

(a)

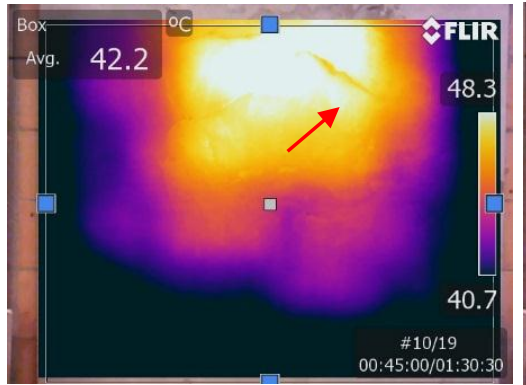

(b)

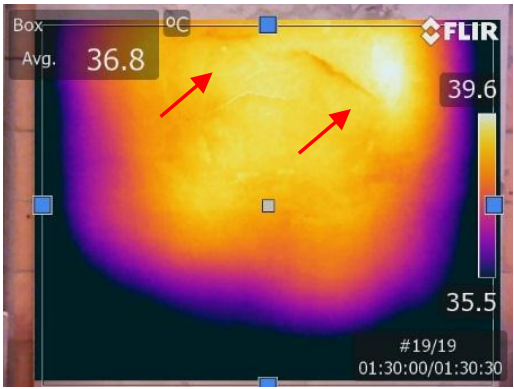

(c)

Figura 156. Termogramas de fissuras do Painel PCE2-B após aquecimento com painel térmico: (a) Imediatamente após aquecimento; (b) 45 minutos após aquecimento; noventa minutos após aquecimento. (Fonte: Elaborado pelo autor).

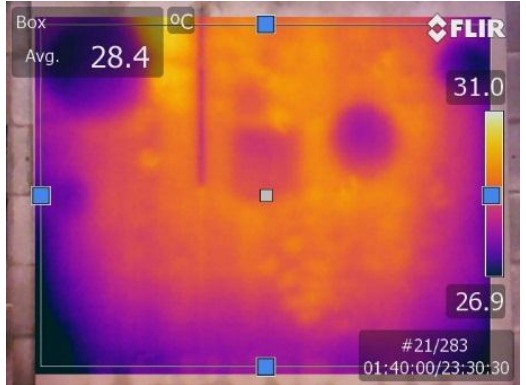

(a)

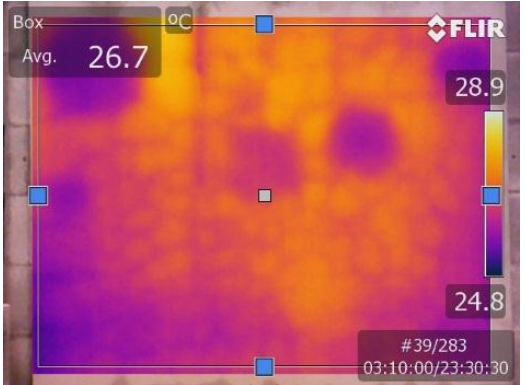

(b)

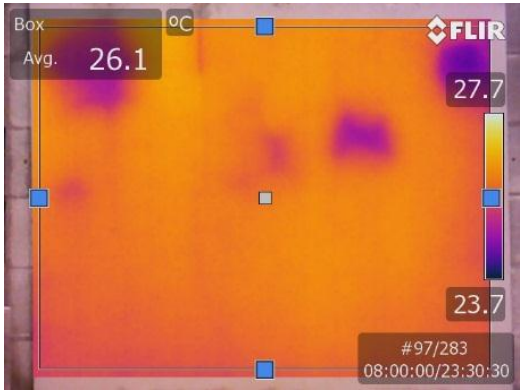

(c)

Figura 157. Termogramas de fissuras do Painel PCO2A após aquecimento com painel térmico e resfriamento com água: (a) 100 minutos após (início da visualização das fissuras), (b) 190 minutos após (momento de melhor visualização das fissuras), (c) 480 minutos após (fim da visualização dos defeitos). (Fonte: Elaborado pelo autor).

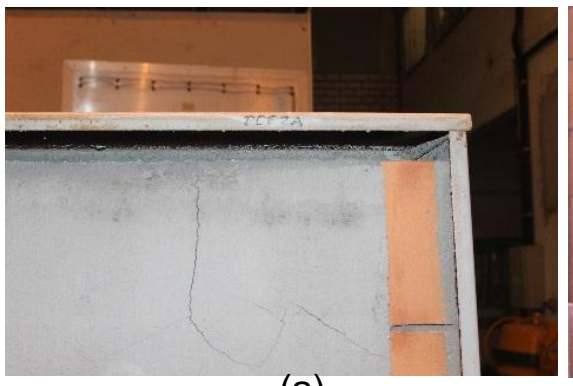

(a)

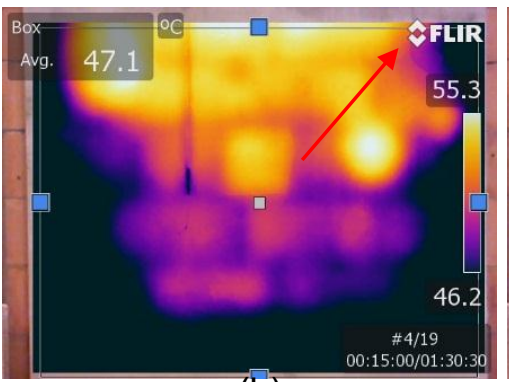

(b)

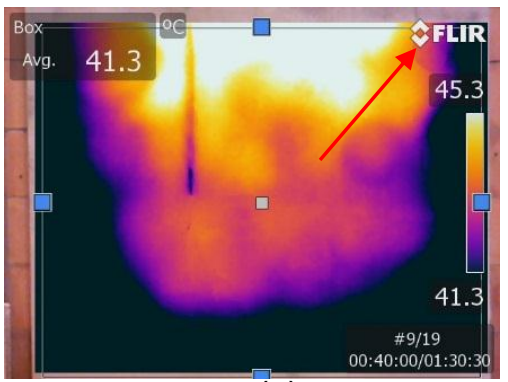

(c)

Figura 158. Painel PCE2-A: (a) Imagem digital da fissura presente no canto superior direto do painel; (b) Termograma quinze minutos após o aquecimento; (c) Termograma quarenta minutos após o aquecimento. (Fonte: Elaborado pelo autor). 


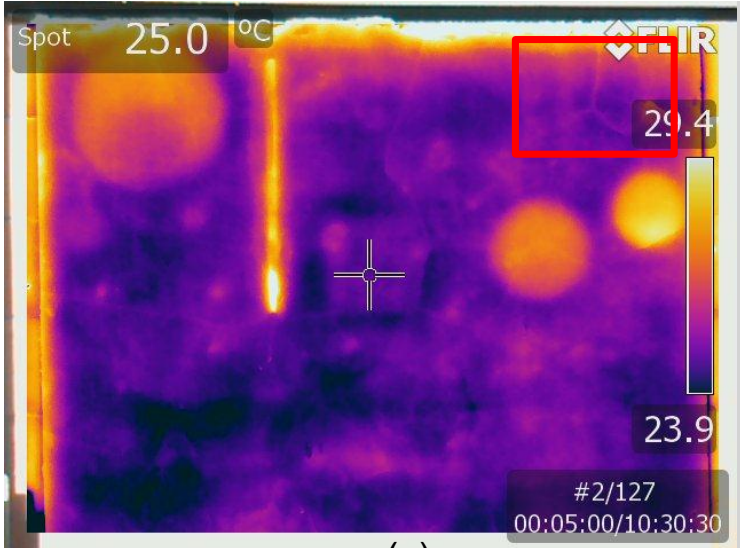

(a)

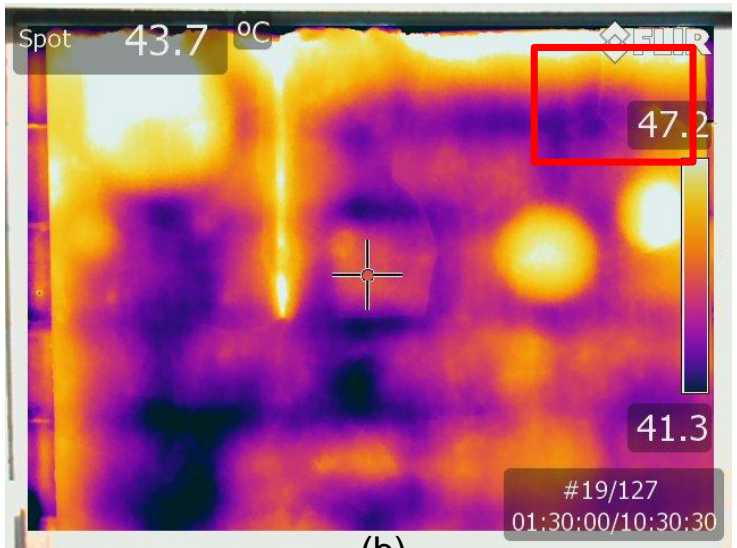

(b)

Figura 159. Termograma da microfissura presente no canto superior direto do painel PCE2A: (a) cinco minutos após início do aquecimento ao sol; (a) noventa minutos após início do aquecimento ao sol. (Fonte: Elaborado pelo autor).

\subsubsection{Defeitos de fissuras in situ}

No caso específico de fachadas, a distância de visualização, as dimensões das fissuras e o tipo de acabamento aplicado sobre o reboco (pintura lisa ou texturizada) podem dificultar ou até inviabilizar a identificação desse tipo de defeito a olho nu (Figura 160-a; Figura 161-a). Nesse contexto, foram realizados na etapa de campo, termogramas em fachadas para identificar as fissuras registradas a pequenas e longas distâncias e posicionadas em diferentes alturas.

Foi possível verificar que, dependendo do gradiente térmico existente entre o defeito e a superfície ao redor, o defeito é visualizado no termograma de forma clara e bem destacada a pequenas distâncias (10 m) (Figura 160-b e Figura 162-b) ou de forma não tão detalhada a grandes distâncias e no enquadramento de grandes áreas, porém deixando clara a existência do defeito, sua posição e sua abrangência na fachada (Figura 161-b).

Nessa condição, as melhores visualizações ocorreram nas seguintes condições:

- durante o início do aquecimento da superfície da fachada pelo sol. Condição em que as microfissuras eram visíveis com uma temperatura mais baixa do que a área sem defeito durante o período de secagem devido à presença de umidade;

- durante o início do resfriamento da superfície da fachada sombreada que sofreu o efeito de aquecimento da radiação solar em algum período 
do dia - condição em que a fissura apresentou-se mais quente que a superficie à sua volta devido à maior capacidade térmica da água presente na fissura.

Apesar da grande variedade de parâmetros que influenciam as medições da termografia infravermelha, em condições in situ, usada como técnica complementar para identificar a presença de microfissuras é possível extrair uma dimensão do problema e direcionar assertivamente para as áreas a serem investigadas com maior detalhe e atenção.

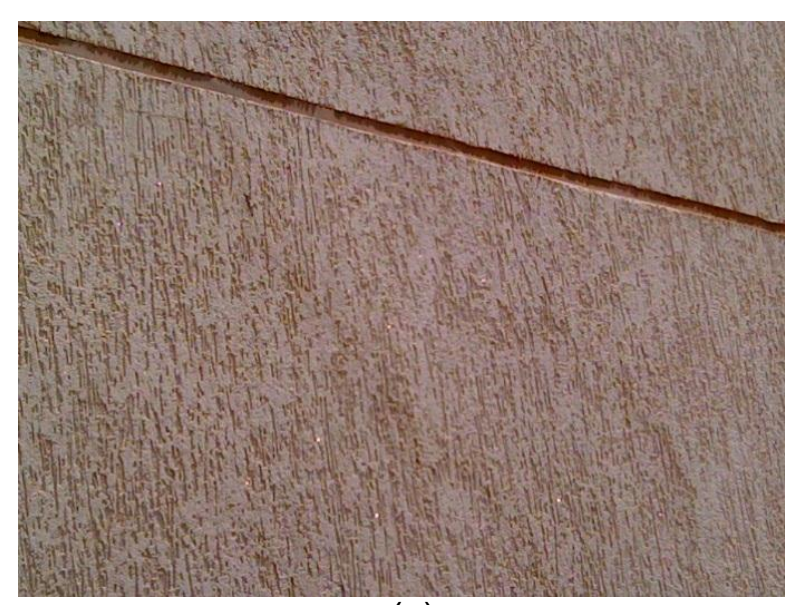

(a)

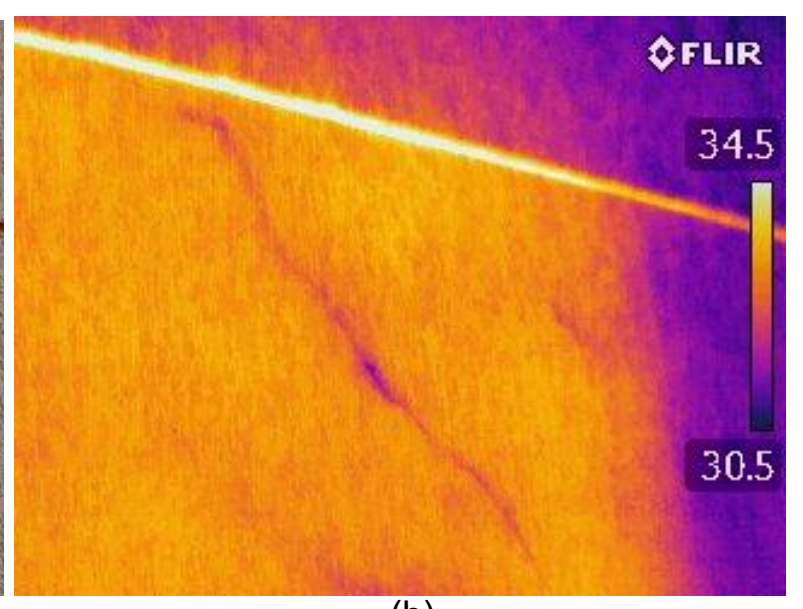

(b)

Figura 160. (a) Imagem digital de fissura na fachada ocultada pelo revestimento e pela distância; (b) Termograma da fissura. (Fonte: Elaborado pelo autor).

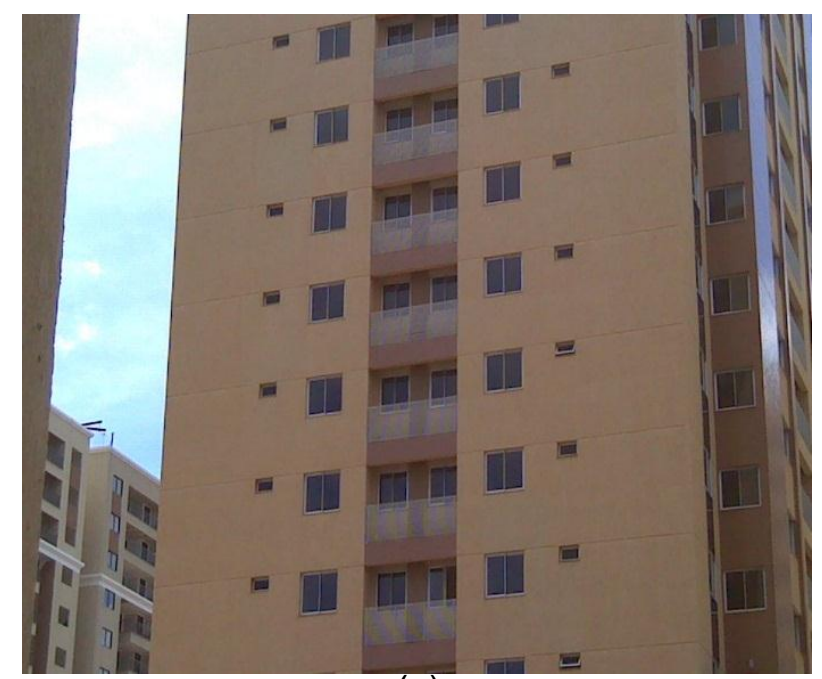

(a)

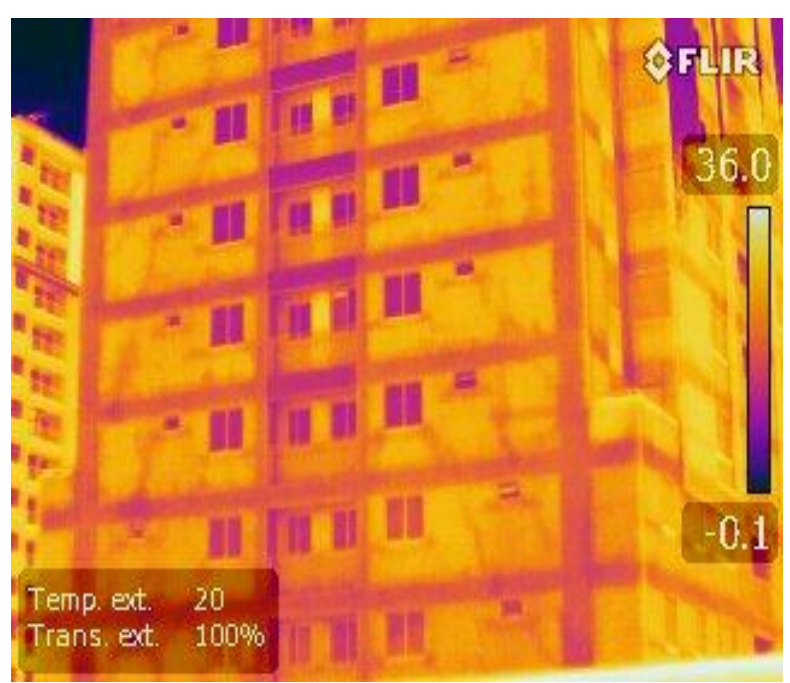

(b)

Figura 161. (a) Imagem digital de fachada fissurada não visível a olho nu; (b) Termograma da fachada fissurada. (Fonte: Elaborado pelo autor). 


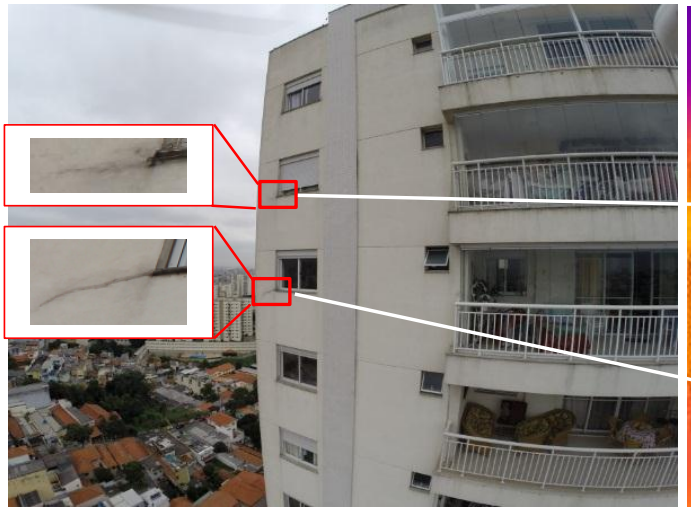

(a)

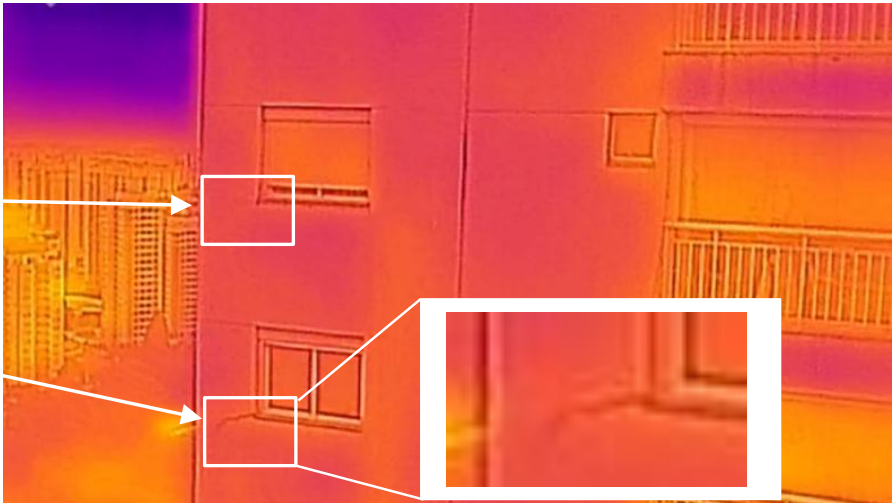

(b)

Figura 162. Imagens com uso de drone: (a) Fissuras nos cantos das janelas, caraterísticas de falhas na execução da contraverga; (b) Termogramas das fissuras de canto de janela.

(Fonte: Elaborado pelo autor).

\subsubsection{Considerações}

\subsubsection{Laboratório e Campo}

Imediatamente após o aquecimento, áreas de vazios/descolamentos apresentam maiores valores de temperatura devido ao espaço de ar formado entre o revestimento e o substrato, gerando acúmulo de energia térmica durante o tempo de exposição ao aquecimento.

Os defeitos menores sob o revestimento de argamassa não puderam ser observados na maior parte dos termogramas. Quando visualizados são facilmente confundidos com "manchas térmicas" causadas por condições variadas da superfície do reboco, como imperfeições de acabamento, diferenças de rugosidade da argamassa, áreas com diferentes tonalidades da própria argamassa.

Vários fatores influenciam a visibilidade dos defeitos: tamanho e natureza dos defeitos, profundidade, gradiente térmico entre defeito e área em volta, momento da leitura, se durante o resfriamento ou aquecimento. Em geral, um grande defeito é mais distinguível do que um menor.

Quanto maior o defeito, a uma mesma profundidade, é possível observar um acúmulo maior de energia térmica e uma velocidade maior de aquecimento e resfriamento da superfície. 
Quanto mais profundo o defeito maior a espessura de revestimento e mais lento é o aquecimento e o resfriamento, permitindo uma visualização do defeito por um período de tempo maior, já que a redução do gradiente térmico leva mais tempo para ocorrer.

Um defeito mais profundo aparece desfocado porque a dispersão térmica no interior do reboco se torna mais intenso à medida que a espessura do reboco aumenta.

Durante o resfriamento, os defeitos passam por uma inversão térmica na qual mudam de uma condição mais quente para uma mais fria em relação às áreas sem defeito. Nesse processo, as bordas apresentam-se ligeiramente menos intensas que as áreas mais centrais do defeito, porém sem perder a definição de forma em razão da dispersão térmica e em diferentes momentos ocorrem períodos de baixo gradiente térmico em que os defeitos ficam pouco ou nada visíveis nos termogramas.

O tempo de visualização do defeito é praticamente o mesmo para diferentes espessuras de reboco, pois, apesar do defeito mais profundo ter aquecido menos que o mais superfícial, ele resfria mais lentamente, podendo inviabilizar a diferenciação pelo requisito espessura em idades mais avançadas do resfriamento.

A precisão das imagens permitiu identificar o tamanho e a forma dos defeitos (reiais e criados). A espessura maior ou menor do reboco, em função da espessura do defeito, pode ser observada tanto pela temperatura alcançada após (painel térmico) ou durante (sol) a exposição à radiação térmica quanto pela velocidade de aquecimento ou resfriamento da superfície. Isso porque menores espessuras possuem menor armazenamento térmico e maior velocidade de troca.

Qualitativamente, as diferenças de comportamento entre os painés com substrato de tijolo cerâmico e bloco de concreto na identificação dos defeitos não foi representativa. Para avaliar com mais certeza precisa ser realizada uma avaliação quantitativa.

Quando se utiliza o resfriamento forçado com água, os defeitos ficam visíveis por menos tempo e a melhor condição de visualização ocorre em torno de 40 minutos após o resfriamento.

$\mathrm{Na}$ etapa de campo, a uniformidade na distribuição de radiação térmica sobre a superfície dos painéis pela incidência solar permitiu a mesma condição de visualização dos defeitos em toda a área do painel quando comparado com os painéis 
aquecidos com o painel térmico no laboratório onde a distribuição de temperatura sobre a superfície não foi uniforme e os pontos de medição selecionados não receberam exatamente a mesma quantidade da energia.

A qualidade visual dos defeitos no revestimento cerâmico quanto à dimensão e a definição das bordas logo após o resfriamento forçado com água aproxima-se da observada no termograma imediatamente após o aquecimento com painel térmico, isso ocorre devido ao choque térmico gerado pela água em contato com a superfície aquecida, aumentando o gradiente térmico e melhorando o contraste entre áreas com e sem defeito.

Foi possível observar defeito de descolamento no revestimento cerâmico sobreposto a defeitos de descolamento na interface revestimento de argamassa/substrato (alvenaria). A melhor condição ocorreu durante o período de menor gradiente térmico registrado no resfriamento, sendo possível visualizar os dois defeitos sob o reboco, porém houve apenas um com boa definição de forma e de dimensões representado pela seta branca.

Também foi possível observar as juntas de assentamento da alvenaria de bloco de concreto e tijolo cerâmico nos termogramas da superfície do reboco.

As microfissuras foram bem visualizadas na superfície do reboco em resfriamento três horas após o início do resfriamento forçado com água.

\subsubsection{In situ}

A técnica utilizada de termografia passiva (sol) demonstrou-se com desempenho satisfatório na identificação de defeitos ocultos na fachada, mesmo com restrições em alguns períodos, sendo necessário planejar a visita levando em consideração as condições climáticas.

Pelas informações cruzadas com o mapeamento por percussão, comprovou-se a assertividade e a confiabilidade do termograma na identificação do local e extensão dos defeitos, ratificando a capacidade da técnica de mapear qualitativamente o descolamento do revestimento cerâmico oculto na fachada. 
Em algumas regiões, os defeito foram identificados apenas nos termogramas e comprovados por meio de imagens digitais de alta resolução, apontando falhas cometidas durante os ensaios de percussão que podem estar associadas à limitação dessa técnica ou do profissional que executou o ensaio.

Caracterizou-se como operacionalmente simples e rápida apesar de altamente teconológica em razão das seguintes comprovações:

- realizada em apenas 90 minutos, cerca de $10 \%$ do tempo gasto para mapear a mesma área da fachada pela técnica da percussão;

- realizada do solo e a distância, sem a necessidade de contato com a superfície do revestimento em análise;

- quando acoplada a um drone a câmera térmica se aproxima das áreas de defeito em substituição ao balancim ou "cadeirinha".

Reduz os riscos associados ao trabalho em altura e minimiza o incômodo aos usuários quando realizado em edificações habitadas.

Como ferramenta de controle de execução/recuperação de defeitos de desplacamento em revestimento cerâmico de fachada os termogramas dos defeitos apresentam um padrão de comportamento em relação às áreas sem defeito:

- as áreas recuperadas se apresentam mais frias à sombra e mais quentes ao sol do momento logo após a aplicação até a secagem da argamassa. Isso ocorre porque a presença de água aumenta a condutividade térmica e pode aumentar o fluxo de calor.

Constatou situações em que condições naturais da superfície em análise geram interferências nos termogramas e precisam ser consideradas, a fim de evitar erros de interpretação dos termogramas:

- mudar o ângulo e a distância do equipamento de termografia em relação à fachada e o horário de captura das imagens térmicas podem reduzir ou eliminar interferências de reflexo do sol sobre o revestimento cerâmico da fachada;

- restringir a leitura térmica a pequenas áreas de interesse em vez de grandes áreas, como a de uma fachada inteira, e considerar o tempo de exposição ao 
sol do local em análise pode fazer a diferença entre identificar ou não o defeito, principalmente se a diferença térmica entre o defeito e a área ao redor for pequena;

- identificar todas as possíveis interferência associadas à vizinhança ou à própria edificação em análise é condição para iniciar os ensaios.

Os recursos de zoom, amplitude térmica e a paleta de cores mostraram-se eficientes para destacar os defeitos.

Os ensaios in situ mostraram que a visualização das microfissuras através dos termogramas é altamente dependente das condições meteorológicas. Em dias nublados não foi possível detectar esse defeito devido ao baixo efeito de aquecimento da radiação solar. Nos dias de sol foi possível a detecção com o efeito da luz do sol, mas somente quando a carga de radiação solar é suficientemente elevada e a diferença de temperatura entre a fachada e o ar foi significativa. As microfissuras eram visíveis com uma temperatura mais baixa do que a área sem defeito durante o período de secagem, embora o defeito também possa ser identificado a olho nu durante o processo de secagem.

Foi possível verificar in situ que, dependendo do gradiente térmico existente entre o defeito e a superfície ao redor, o defeito é visualizado no termograma de forma clara e bem destacada a pequenas distâncias $(10 \mathrm{~m}$ ) ou de forma não tão detalhada a grandes distâncias e no enquadramento de grandes áreas, porém deixando clara a existência do defeito, sua posição e sua abrangência na fachada.

Até que novos estudos sejam realizados, recomenda-se o uso da termografia com técnica de análise complementar às tradicionais. 


\section{CONCLUSÕES}

$\mathrm{Na}$ obra foco deste estudo, o objetivo do trabalho foi alcançado à medida que o escaneamento 3D laser mostrou-se preciso e economicamente viável para levantamento volumétrico do consumo de argamassa da fachada por meio da aplicação do método proposto, sinalizando redução de custo de argamassa aplicada que variava de $18 \%$ a $47 \%$ ao identificar as sobrespessuras geradas pelas imperfeições na planicidade da fachada.

Também mostrou ser uma ferramenta eficiente para o mapeamento da fachada, expondo a influência do grau de controle geométrico da estrutura na regularidade superficial da fachada, podendo contribuir nas tomadas de decisão referentes às medidas corretivas das imperfeições que impactam nas espessuras de argamassa mediante a abrangência das áreas críticas.

Já o emprego da técnica de termografia digital é uma realidade possível e representa um salto qualitativo em obra. Pelas informações cruzadas com o mapeamento por percussão, a termografia mostrou assertividade e confiabilidade na identificação do local e extensão dos defeitos, ratificando a capacidade da técnica de mapear qualitativamente o descolamento do revestimento cerâmico oculto na fachada.

Não foi definido um padrão que permita criar uma relação entre a espessura e a profundidade do defeito com o termograma. É possível apenas de forma qualitativa observar em laboratório se um defeito está mais próximo ou mais afastado da superfície em função da velocidadae de aquecimento ou resfriamento da superfície. In situ é difícil afirmar que tal comportamento observado nos termogramas se refira a essa causa, dado que outras possibilidades podem gerar a mesma interpretação, como regiões que recebem incidência de radiação devido à reflexão de prédios vizinhos.

Em razão disso, é fundamental - em casos de fachada - uma observação criteriosa sobre a vizinhança da edificação e suas influências na superfície da fachada em estudo, evitando erros na interpretação das informações e diagnósticos equivocados.

As tecnologias atuam de forma complementar no controle preventivo e corretivo das edificações. 


\subsection{Sugestões para futuras pesquisas/aplicações}

\section{- Escaneamento 3D laser}

- aprofundar os estudos no uso do elevado grau de detalhamento da superfície gerado pelo modelo escaneado, para verificar a regularidade de alinhamento dos blocos, posicionamento da alvenaria em relação a vigas e pilares, espessura da argamassa de assentamento da alvenaria, atribuindo à técnica a possibilidade de uso como método de controle de qualidade do processo produtivo/executivo da etapa de alvenaria.

- pesquisar o uso do escaneamento 3D laser durante a execução da estrutura para aferir e corrigir as falhas de alinhamento e nivelamento das fôrmas, permitindo corrigi-las antes da concretagem.

As duas linhas de pesquisa citadas são consideradas preventivas na medida que impedem que as falhas ocorram e reflitam nas etapas seguintes, ao contrário do uso corretivo proposto neste trabalho.

\section{- Termografia infravermelha}

- o aumento do uso de diferentes tipos de telas na fachada como recurso de dissipação de tensões e de estruturação dos revestimentos de argamassa e cerâmicos aderentes desperta para a necessidade de técnicas de controle durante a execução que permitam seu mapeamento sob o revestimento viabilizando medidas preventivas e corretivas incipientes, caso necessário. Nessa linha, a termografia IR apresenta elevado potencial, no entanto não foram encontrados estudos voltados a essa aplicação.

- a realização de novos estudos de casos comparativos como o realizado neste trabalho para estabelecer padrões qualitativos de análise de defeitos de desplacamento, fissuras e identificação de novos defeitos.

- avançar nos estudos experimentais para estabelecer padrões quantitativos e melhorar os padrões qualitativos (forma, dimensão, espessura, posição e localização) de análise e medição de defeitos de descolamentos e fissuras ocultos entre o substrato e a argamassa em condições de temperatura e umidade do ar controlados $\left(21^{\circ} \mathrm{C}\right.$ e $60 \%$ UR). 


\section{REFERÊNCIAS BIBLIOGRÁFICAS}

A. Moropoulou, N.P. Avdelidis, The role of emissivity in infrared thermographic imaging and testing of building and structural materials. In: X.P.V. Maldague, A. E. Rozlosnik (Eds.), Thermosense XXIV, SPIE Press, Orlando, Florida, USA, 2002, pp. 281-287.

AGOPYAN, V._et al. Alternativas para redução do desperdício em canteiros de obra. São Paulo: Universidade de São Paulo, 1998.

AKBARZADEH et al. Proc: Third International Symposium on 3D Data Processing, Visualization and Transmission, 3DPVT, 2006.

ALVES, A. S. Estudo da propriedade resistência superficial em revestimentos de argamassa. 2009. 159 f. . Tese de Doutorado. Dissertação (Mestrado em Engenharia Civil) - Escola de Engenharia Civil, Universidade Federal de Goiás, Goiânia, 2009.

AMERICAN SOCIETY FOR TESTING AND MATERIALS. ASTM - E 632-82/96: Standard Practice for Developing Accelerated Tests to aid Prediction of the Service Life of Building Components and Materials. Philadelphia.

Annual SPIE thermosense conferences, Bellingham, WA; 1978-2002.

ANTUNES, G. R. Estudo de manifestações patológicas em revestimento de fachada em Brasília - sistematização da incidência de casos. 2010. xxi, 178 f., il. Dissertação (Mestrado em Estruturas e Construção Civil) - Universidade de Brasília, Brasília, 2010.

ANTUNES, R. Influência da reologia e da energia de impacto na resistência de aderência de revestimentos de argamassa. 2005. Tese (Doutorado em Engenharia Civil) - Escola Politécnica da Universidade de São Paulo Departamento de Engenharia Civil, São Paulo, 2005.

APICER, CTCV e DEC-FCTUC - Manual de Aplicação de Revestimentos Cerâmicos. COIMBRA, 2003.

ARAÚJO JR. J. M. Contribuição ao estudo das propriedades físico-mecânicas das argamassas de revestimento. 2004. 175 f. Dissertação (Mestrado) - Faculdade de Tecnologia, Universidade de Brasília, Brasília, 2004.

ASSOCIAÇÃO BRASILEIRA DE NORMAS TÉCNICAS. NBR 5674. Manutenção de edificações- Procedimentos. Rio de Janeiro: ABNT, 2012.

. NBR 7200: Execução de revestimento de paredes e tetos de argamassas inorgânicas: procedimento. Rio de Janeiro: ABNT, 1998.

. NBR 9575: Impermeabilização - Seleção e projeto: Terminologia. Rio de Janeiro: ABNT, 2010.

NBR 13528: Determinação da resistência de aderência a tração. Rio de Janeiro: ABNT, 2010. 
. NBR 13529: Revestimentos de paredes e tetos de argamassas inorgânicas: Terminologia. Rio de Janeiro: ABNT, 2013.

. NBR 13749: Revestimentos de paredes e tetos de argamassas inorgânicas - Especificação. Rio de Janeiro: ABNT, 2013.

NBR 13755: Revestimentos de paredes externas e fachadas com placas cerâmicas e com utilização de argamassa colante - Procedimento. Rio de Janeiro: ABNT, 1996.

. NBR 13816: Placas cerâmicas para revestimento - Terminologia. Rio de Janeiro: ABNT, 1997.

. NBR 14081: Argamassa colante industrializada para assentamento de placas cerâmicas - Requisitos. Rio de Janeiro: ABNT, 2012.

. NBR 14992: Argamassa a base de cimento Portland para rejuntamento de placas cerâmicas - Requisitos e métodos de ensaio. Rio de Janeiro: ABNT, 2003.

NBR 15575-1: Edifícios habitacionais - Desempenho - Parte 1: Requisitos gerais. Rio de Janeiro: ABNT, 2013.

NBR 15575-4: Edifícios habitacionais - Desempenho - Parte 4: Sistemas de vedações verticais internas e externas. Rio de Janeiro: ABNT, 2013.

ASTM - C 1060-90 Standard practice for thermographic inspection of insulation installations in envelope cavities of frame buildings. West Conshohocken: American Society for Testing and Materials (ASTM) International; 2003.

.ASTM C1153-10 Standard practice for location of wet insulation in roofing systems using infrared imaging. West Conshohocken: American Society for Testing and Materials (ASTM) International; 2010.

.ASTM E1933-97, Standard Test Methods for Measuring and Compensating for Emissivity Using Infrared Imaging Radiometers, American Society for Testing and Materials, Pennsylvania, USA, 1997.

BAÍA, L.L.M.; SABBATINI, F.H. Projeto e execução de revestimento de argamassa. CTE, São Paulo: O Nome da Rosa, 2000. p. 82.

BARREIRA, E. Thermography applications in the study of buildings higrothermal behaviour. M.Sc. theses, Porto, FEUP; 2004. [Portuguese]

BARREIRA, E.; FREITAS, V. P. Infrared thermography applications in the study of building hygrothermal behaviour. CIB W40 Meeting, Caledonian University, Glasgow; 2004.

BARREIRA, E.; FREITAS, V. P. Importance of thermography in the study of ETICS finishing coatings degradation due to algae and mildew growth. In: 10DBMC international conference on durability of building materials and components proceedings, CSTB, Lyon; 2005. 
BARROS, E. O. Controle geométrico da estrutura de concreto de edifícios como ferramenta da racionalização construtiva. 2001. 136 f. Tese de Doutorado. Dissertação (mestrado) - Escola Politécnica - USP. São Paulo, 2001.

BARROS, M. M. B.; TANIGUTI, E. K.; RUIZ, L. B., SABBATINI, F. H. Tecnologia Construtiva para produção de Revestimentos Verticais. São Paulo, 1997. Notas de aula.

BASTOS, P. K. X. Módulo de deformação de argamassas - conceitos e métodos de determinação. In: SIMPÓSIO BRASILEIRO DE TECNOLOGIA DAS ARGAMASSAS, 5. 2003. São Paulo. Anais... São Paulo: EPUSP-PCC/ANTAC, 2003. p. $27-40$.

BERNARDINI, F.; RUSHMEIER, H. The 3D Model Acquisition Pipeline. Computer Graphics Forum, v. 21, n. 2, p. 149-172, jun. 2002.

BERTIL P., BENGT A. Thermography - testing of the thermal insulation and airtightness of buildings. Stockholm: Swedish Council for Building Research; 1980.

BERTOLINI, Luca. Materiais de construção: patologias, reabilitação. São Paulo: Oficina de textos, 2010.

Biennial quantitative infrared thermography (QIRT) conference; 1992-2002.

BOEHLER, W.et al. Investigating laser scanner accuracy. The International Archives of Photogrammetry, Remote Sensing and Spatial Information Sciences, v. 34, n. Part 5, p. 696-701, 2003.

CAMPANTE, E. F. Metodologia para diagnóstico, prevenção e recuperação de manifestações patológicas em revestimentos cerâmicos de fachada. 2001. 408 p. Tese (Doutorado) - Escola Politécnica da Universidade de São Paulo, Departamento de Engenharia e Construção Civil, São Paulo, 2011.

CANDIA, M.C. Contribuição ao estudo das técnicas de preparo da base no desempenho dos revestimentos de argamassa. 1998. $262 \mathrm{p}$. Tese (Doutorado) - Escola Politécnica, Universidade de São Paulo, 1998.

CARASEK, H.; CASCUDO, O.; SCARTEZINI, L. M. Importância dos materiais na aderência dos revestimentos de argamassa. In: SIMPÓSIO BRASILEIRO DE TECNOLOGIA DAS ARGAMASSAS, 4º, Brasília, 23 a 25 de maio de 2001. Anais. Brasília, UnB/ANTAC, 2001. p. 43-67.

CARASEK, Helena. Fatores que exercem influência na resistência de aderência de argamassas. Anais do II Simpósio Brasileiro de Tecnologia das Argamassas. Salvador. 1997. p. 133-146.

CARNEIRO, A.M. P.; CINCOTTO, M. A. Requisitos e critérios de desempenho para revestimento de camada única em argamassa de cimento e cal. In: Simpósio Brasileiro de Tecnologia das Argamassas, 1ํㅡ, Goiânia/GO, 1995. Artigo técnico.

C. Hagentoft: Introduction to Building Physics (Student Litteratur, Sweden, 2001). 
CARVALHO JR., A. N. Avaliação da aderência dos revestimentos argamassados: uma contribuição à identificação do sistema de aderência mecânico. Belo Horizonte, 2005. Tese (Doutorado) - Curso de Pós-Graduação em Engenharia Metalúrgica e de Minas, Universidade Federal de Minas Gerais, Belo Horizonte, 2005.

CEN. EN 13187. Thermal performance of buildings - qualitative detection of thermal irregularities in building envelops - infrared method. Brussels: European Committee for Standardization; 1998.

CEOTTO, L. H.; BANDUK, R. C.; NAKAKURA, E. H. Revestimentos de argamassas: boas práticas em projeto, execução e avaliação. Porto Alegre: ANTAC, 2005. 96 p. (Recomendações técnicas Habitare, v.1).

CHAVES, A. M. Patologia e reabilitação de revestimentos de fachadas. 2009. 176 p. Dissertação (Mestrado) - Universidade do Minho. Braga Portugal, 2009.

CINCOTTO, M. A. Patologia das argamassas de revestimento: análise e recomendações. In: SIMPÓSIO DE DESEMPENHO DE MATERIAIS E COMPONENTES DE CONSTRUÇÃO CIVIL, 1., 1988, Florianópolis. Anais... Florianópolis: UFSC, 1988. p. 157-170.

CINCOTTO, M. A.; SILVA, M. A. C; CARASEK, H. Argamassas de revestimento: características, propriedades e métodos de ensaio. São Paulo: Instituto de Pesquisas Tecnológicas (Publicação IPT 2378), 1995, 118 p. Boletim Técnico 68 IPT.

CONSOLI, O. J. Análise da durabilidade dos componentes das fachadas de edifícios, sob a ótica do projeto arquitetônico. 2006. 208 p. Dissertação (Mestrado) Programa de Pós Graduação em Engenharia Civil, Universidade Federal de Santa Catarina, Florianópolis, 2006.

COSTA, F. N. Processo de produção de revestimento de fachada de argamassa: problemas e oportunidades de melhoria. 2005.

COSTA, E.; CARASEK, H. Investigação do método de ensaios de determinação da resistência de aderência de revestimentos de argamassa. Escola de Engenharia Civil, Universidade Federal de Goiás. Curso de Mestrado em Engenharia Civil, Goiânia, 2007.

CORTIZO, E. C. Avaliação da técnica de termografia infravermelha para identificação de estruturas acultas e diagnóstico de anomalias em edificações: ênfase em edificações do patrimônio histórico. s. L.: s. Ed.: 2007.

CURLESS, Brian. From range scans to 3D models. ACM SIGGRAPH Computer Graphics, v. 33, n. 4, p. 38-41, 1999.

DAL MOLIN, D. C. C. Fissuras em estruturas de concreto armado: análise das manifestações típicas e levantamento de casos ocorridos no estado do Rio Grande do Sul. 1988. 220 p. Dissertação (Mestrado em Engenharia) - Curso de Pós-Graduação em Engenharia Civil. Universidade Federal do Rio Grande do Sul, Porto Alegre, 1988. 
DAVIS, J. et al. Filling holes in complex surfaces using volumetric diffusion. In: 3D Data Processing Visualization and Transmission, 2002. Proceedings. First International Symposium on. IEEE. P. 428-441, 2002.

DUARTE, R. (2009) - In-situ techniques to evaluate the in-service performance related to water. Master dissertation in Building Engineering, Lisbon: Instituto Superior Técnico, 147 p. [Portuguese]

EDIS, E.; FLORES-COLEN, I.; BRITO, J. Passive thermographic detection of moisture problems in façades with adhered ceramic cladding, 2014.

EL-HAKIM, S.F. et al. "A Comparative Evaluation of the Performance of Passive and Active 3-D Vision Systems", SPIE Proceedings Volume 2646, Conference on Digital Photogrammetry, 1995, p. 14-25.

F.P. Incropera and D.P. Witt: Fundamentals of heat and mass transfer (John Wiley \& Sons, 2001).

FLORES-COLEN, I. (2009) - Methodology for in service performance evaluation of render from the perspective of predictive maintenance. $\mathrm{PhD}$ Thesis in Building Engineering, Lisbon: Instituto Superior Técnico, 487 p. [Portuguese]

FIORITO, A. J. S. I. Manual de argamassas e revestimentos: Estudos e Procedimentos de Execução. 4. ed. São Paulo: Pini, 1994. 223 p.

FLIR. Manual do Usuário. São Paulo, 2009.

FRUEH C. et al. Data processing algorithms for generating textured 3D building facade meshes from laser scans and camera images. International Journal of Computer Vision (IJCV) 61 (2). p. 159-184, 2005.

GALVÃO, J. In-situ techniques for render mechanical performance - rebound hammer and ultra-sound. MSc in Building Engineering, Lisboa: Instituto Superior Técnico, 2009. 177p. [Portuguese]

GASPAR, P.; FLORES-COLEN, I.; BRITO, J. (2007) - Diagnosys techniques for anomally classification render adhesion. In: 2nd National Congress of Construction Renders, APFAC, Lisbon, 22-23 de November, CD-Rom. [Portuguese]

GOLPARVAR-FARD, M. et al. Evaluation of image-based modeling and laser scanning accuracy for emerging automated performance monitoring techniques. Automation in Construction, v. 20, n. 8. p. 1143-1155, dez. 2011.

GONÇALVES, S. R. C. (2004). Variabilidade e fatores de dispersão da resistência de aderência nos revestimentos em argamassa - estudo de caso. Dissertação de Mestrado, Publicação E.DM-004 A/04, Departamento de Engenharia Civil, Universidade de Brasília.

GRINZATO, E., BISON, P. G, MARINETTI, S. Monitoring of ancient buildings by the thermal method. J Cult Heritage 2002;3(1):21-9. 
GRYZAGORIDIS, J. Laser Based Nondestructive Inspection Techniques. Journal of Nondestructive Evaluation, v. 31, n. 4. p. 295-302, dez. 2012.

HAECKER, C. J.; GARBOCZI, E. J.; BULLARD, J. W.; BOHN, Z. S.; SHAH, S. P.; VOIGT, T. Modeling the linear elastic properties of Portland cement paste. Cement and Concrete Research, n. 35, p. 1948-1960, 2005.

HART, J. M. A practical guide to infrared thermography for building surveys. Garston, Watford, BRE; 1991.

HOLST, Gerald C. Common Sense approach to thermal imaging. Winter Park (FL): JCD Publishing, 2000. 377 p.

INCROPERA, F., DEWITT, D.P. "Fundamentos de Transferência de Calor e Massa", 5a edição, LTC Editora, Rio de Janeiro-RJ, Brasil, 2003.

ISO. ISO 6781 Thermal insulation - qualitative detection of thermal irregularities in building envelopes - infrared method. Switzerland: International Organization for Standardization; 1983.

. ISO 7976-2 Tolerances for building - Methods of measurement of buildings and building products. Part 2: position of measuring points - Switzerland, 1989.

JASELSKIS, E. J.; GAO, Z. Pilot Study on Laser Scanning Technology for Transportation Projects. Proceedings of the 2003 Mid-Continent Transportation Research Symposium, Ames, lowa, August 2003.

JOHN, V. M.; SATO, N. M. N. Durabilidade de componentes da construção. In: Coletânea Habitare - Construção e meio ambiente, Porto Alegre: ANTAC, v. 7, 2006, p. 21-57.

JOHN, V. M. Repensando o papel da cal hidratada nas argamassas. In: SIMPÓSIO BRASILEIRO DE TECNOLOGIA DAS ARGAMASSAS, 5, 2003. São Paulo. Anais... São Paulo: EPUSP-PCC/ANTAC, 2003. p. 47-64.

LABRINCHA, J. Associação para o desenvolvimento da casa do futuro.

Universidade de Aveiro, 2006. Disponível em:

<http://www.aveirodomus.pt/resources/xFiles/scContentDeployer/docs/Doc266.pdf>. Acesso em: 02 jun. 2015.

LEAL, F. E. C. B. Estudo do desempenho do chapisco como procedimento de prevenção de base em sistemas de revestimento. 2003. Dissertação (Mestrado em Estruturas e Construção Civil) - Departamento de Engenharia Civil e Ambiental, Universidade de Brasília, Brasília, 2003.

LEMOS, K. B. Q. Manutenção e Reabilitação de Túneis, 2005. Tese (Mestrado). Universidade de Brasília. Faculdade de Tecnologia - Departamento de Engenharia Civil e Ambiental.

LI, Z.; YAO, W.; LEE, S.; LEE, C.; YANG, Z. Application of infrared thermography technique in building finish evaluation. J Nondestr Eval 2000;19(1):11-9. 
LINK, W. Tópicos avançados da metrologia mecânica: confiabilidade metrológica e suas aplicações. 1. ed. Rio de Janeiro, 2000.

LORENZI, A.; CAETANO, F. C.; DRUNN, M. T.; FILHO, L. C. Utilização de ultrasom para o monitoramento de estruturas de concreto, 2003. Artigo PANNDT.

LUÍS, M. A. A. S. IN-SITU ANALYSIS OF THE MECHANICAL PERFORMANCE OF RENDERING FACADES Instituto Superior Técnico / UTL Av. Rovisco Pais, 1049-001 Lisboa, Portugal E-mail: luismaasantos@ist.utl.pt

MACIEL, L. L.; BARROS, M. M. S. B.; SABBATINI, F. H. Recomendações para a execução de Revestimentos de argamassa para paredes de vedação internas e exteriores e tetos. São Paulo: Escola Politécnica da Universidade de São Paulo, 1998.

MALDAGUE, X.P.V. Nondestructive Evaluation of Materials by Infrared Thermography, Springer-Verlag, Berlin, 1993.

MARIO, M. Uso da termografia como ferramenta não destrutiva para avaliação de manifestações patológicas ocultas. 2011. $60 \mathrm{f}$. Trabalho de diplomação (graduação em engenharia civil). Departamento de engenharia civil, Universidade Federal do Rio Grande do Sul, Porto Alegre.

MARTINELLI, F.A. Contribuição ao estudo de dosagem das argamassas mistas destinadas ao assentamento e revestimento de alvenarias. São Paulo, 1989. Dissertação (Mestrado em Engenharia da Construção Civil) CPGECC/Escola Politécnica, Universidade de São Paulo.

MAZER, W. Diagnóstico das patologias. Curso de Especialização em Patologia das Construções. 2011. Notas de Aula. Disponível em: $<\mathrm{http}: / /$ pessoal.utfpr.edu.br/wmazer/arquivos/Notas_Aula_Diagnostico.pdf $>$. Acesso em: 22/06/2015.

MEDEIROS, J. S. Tecnologia e projeto de revestimentos cerâmicos de fachadas de edifícios. 1999. 458 p. Tese (Doutorado) - Escola Politécnica, Universidade de São Paulo, 1999.

MEDEIROS, J. S.; SABBATINI, F. H. Tecnologia e projeto de revestimento cerâmico de fachadas de edifícios. Boletim Técnico: BT/PCC/246. São Paulo: EPUSP, 1999, 28 p.

MEHTA, P. K.; MONTEIRO, P. J. M. Concreto: estrutura, propriedades e materiais. São Paulo: PINI, 1994.

MINKINA, W.; DUDZIK, S. Infrared thermography: errors and uncertainties. Chichester: John Wiley \& Sons; 2009. [20] Rosina E, Ludwig N. Optimal thermographic procedures

A. Moropoulou, N.P. Avdelidis, The role of emissivity in infrared thermographic imaging and testing of building and structural materials, in: X.P.V. Maldague, A.E. Rozlosnik (Eds.), Thermosense XXIV, SPIE Press, Orlando, Florida, USA, 2002, p. 281-287. 
MOTHÉ, Cheila Gonçalves. Análise térmica de materiais. São Paulo: Artliber, 2009.

NERO, J. (2001) - Renders - Part I. Arquitectura e Vida, n. 20, p. 112-117. [Portuguese]

N.P. Avdelidisa, ${ }^{*}$, A. Moropouloub, Emissivity considerations in building thermography Materials Research Centre, University of Bath, Bath BA2 7AY, UK bSection of Materials Science and Engineering, School of Chemical Engineering, National Technical University of Athens, Iroon Polytechniou 9, 15780 Zografou, Athens, Greece Received 30 August 2002; received in revised form 14 October 2002; accepted 14 October 2002.

OLIVEIRA, M.et al. Sistema de indicadores de qualidade e produtividade para a construção civil: manual de utilização. 2. ed. rev. Porto Alegre: Serviço de Apoio as Micro e Pequenas Empresas do Rio Grande do Sul - SEBRAE/RS, 1995.

PAIVA, J. V.; AGUIAR, J.; PINHO, A. Technical guide of rehabilitation of housing. Lisbon: National Institute for Dwellings - Laboratory of Civil Engineering - LNEC, vol. 2; 2006 [Portuguese].

PALLIARI, J.C. et al. Levantamento de perdas/consumo de argamassa de revestimento em obras de construção em edifícios brasileiros. In: III Simpósio Brasileiro de Tecnologia de Argamassas, Vitória, 1999. Anais, p. 715-724.

PEDRO, E. G. et al. Patologia em Revestimento Cerâmico de Fachada. Curso de Pós-Graduação do CECON, Especialização em Engenharia de Avaliações e Perícias. Síntese de Monografia. Belo Horizonte-MG, 2002.

PICCHI, F. A. Sistemas da Qualidade: uso em empresas de construção de edifícios. 1993. 280 p. Tese (Doutorado em Engenharia) - Escola Politécnica da Universidade de São Paulo, Programa de Pós-Graduação em Engenharia, São Paulo, 1993.

PU, S.; VOSSELMAN, G. Knowledge based reconstruction of building models from terrestrial laser scanning data. ISPRS Journal of Photogrammetry and Remote Sensing, v. 64, n. 6, p. 575-584, nov. 2009.

RAO, P. The Indian Concrete Journal Vol. 85 (2008), p. 41.

ROSINA, E.; ROBISON, E. C. Applying infrared thermography to historic woodframed buildings in North America. Assoc Preserv Technol Int (APT) Bullet. 2002;33(4):37-44.

ROSINA, E; LUDWIG, N. Optimal thermographic procedures for moisture analysis in building materials. In: Proceedings of society of photographic instrumentation engineers (SPIE), vol. 3827. 1999; p. 22-33.

SALAMANCA, S. et al. Filling holes in 3D meshesusing image restoration algorithms, Proceedings of the Symposium on 3D Data Processing, Visualization, and Transmission. (Atlanta, GA), 2008. 
SARAIVA, A. G. Contribuição ao estudo de tensões de natureza térmica em sistemas de revestimento cerâmico de fachada. Brasília, 1998. Dissertação (Mestrado) Departamento de Engenharia Civil, Universidade de Brasília, 1998.

SCARTEZINI, L. M. Influência do tipo e preparo do substrato na aderência dos revestimentos de argamassa: estudo da evolução ao longo do tempo, influência da cura e avaliação da perda de água da argamassa fresca. 2002. 262 f. Dissertação (Mestrado) - Curso de Mestrado em Engenharia Civil, Universidade Federal de Goiás, Goiânia, 2002.

SELMO, S. M. S. Dosagem de argamassas de cimento Portland e cal para revestimento externo dos edifícios. São Paulo, 1989. 187 p. Dissertação (Mestrado) - Escola Politécnica, Universidade de São Paulo, 1989.

SELMO, S.M.S. Revestimentos de Argamassas de Paredes e Tetos de Edifícios. Projeto, Execução e Manutenção. Associação Brasileira de Cimento Portland. 1996.

SENTONE, D. T. Desenvolvimento de método para medida de permeabilidade superficial de revestimento de argamassa. São Paulo, 2011. Tese (Doutorado) Escola Politécnica da Universidade de São Paulo - Departamento de Engenharia Civil, 2011.

SILVA, Armando Filipe. Manifestações Patológicas em Fachadas com Revestimento Argamassados. Dissertação (Mestrado em Arquitetura e Urbanismo) - Universidade Federal de Santa Catarina, Florianápolis, 2007.

SILVESTRE, J. D.; DE BRITO, J. Ceramic tiling inspection system. Construction and Building Materials, v. 23, n. 2, p. 653-668, fev. 2009.

SOIBELMAN, L. As perdas de materiais na construção de edificações: Sua incidência e seu controle. Dissertação (Mestrado em Engenharia Civil) - Universidade Federal do Rio Grande do Sul, Porto Alegre, 1993.

SOUZA, R. H. F.; ALMEIDA, I. R. O projeto da UFF para avaliar o desempenho de revestimentos de fachadas. In: IV SIMPÓSIO BRASILEIRO DE TECNOLOGIA DE ARGAMASSAS E I INTERNATIONAL SYMPOSIUM ON MORTARS TECHNOLOGY, 2005, Florianópolis. Anais... CD-ROM.

SU, Y. Y.et al. Integration of Construction As-Built Data Via Laser Scanning with Geotechnical Monitoring of Urban Excavation. Journal of Construction Engineering and Management, v. 132, n. 12, p. 1234-1241, dez. 2006.

VALÉRIO, J. G. M. A. P. Avaliação do impacto das pontes térmicas no desempenho térmico e energético de edifícios residenciais correntes. 2007. $p$ 87. Dissertação (Mestrado em Engenharia Civil) - Instituto Técnico Superior, Universidade Técnica de Lisboa, Lisboa, 2007.

VAVILOV V. Thermal non-destructive testing: short history and state-of-art. In: Balageas D, Busse G, Carlomagno GM, editors. Proceedings of the Qirt_92 conference, Chatenay-Malabry, France; 1992. p. 179-93. 
VEIGA, M. (1998) - Render performance - cracking resistance testing. PhD Thesis in Building Engineering, Oporto: Faculdade de Engenharia do Porto, 458 p. [Portuguese]

VEIGA, M. (2005) - Comportamento de revestimentos de fachadas com base em ligante mineral. Exigências funcionais e avaliação do desempenho Render performance using mineral binders. In: 1st Congresso Nacional de Argamassas de Construção, APFAC, Lisbon, 24-25 de November, CD-Rom. [Portuguese]

XIONG, X. et al. Automatic creation of semantically rich 3D building models from laser scanner data. Automation in Construction, v. 31, p. 325-337, maio 2013.

YOUNG, Hugh D. Física II: Termodinâmica e ondas. 12. ed. São Paulo: Addison Wesley, 2008.

ZHANG, C.; ARDITI, D. Automated progress control using laser scanning technology. Automation in Construction, v. 36, p. 108-116, dez. 2013.

\section{SITES:}

Evolução histórica dos levantamentos a laser | MundoGEO. Disponível em: $<$ http://mundogeo.com/blog/2013/06/05/evolucao-historica-dos-levantamentos-alaser/>. Acesso em: 12 abr. 2015.

3D scanner - Wikipedia, the free encyclopedia. Disponível em: <http://en.wikipedia.org/wiki/3D_scanner>. Acesso em: 12 abr. 2015. 